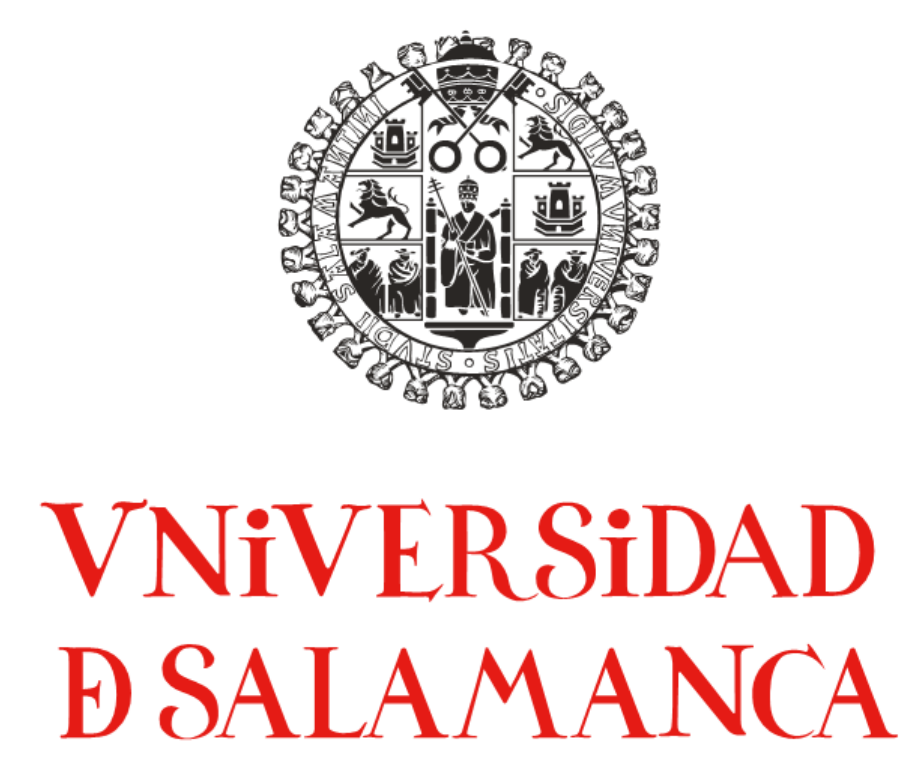

DEPARTAMENTO DE BIOQVÍMICA Y BíOLOGía MOLECVLAR

\title{
PAPEL DE LA ALFA-FETOPROTEÍNA EN EL DESARROLLO EMBRIONARIO DEL CEREBRO
}

ALEJANDRO GARCÍA GARCÍA 

D. JOSÉ MARÍA MEDINA JIMÉNEZ, Catedrático de Universidad, Da. ARÁNZAZU TABERNERO URBIETA, Profesora Titular de Universidad y Da. ANA PURIFICACIÓN VELASCO CRIADO Profesora Ayudante Doctor, adscritos al Departamento de Bioquímica y Biología Molecular de la Universidad de Salamanca

\section{AUTORIZAN}

La presentación de la Tesis Doctoral: "Papel de la alfa-fetoproteína en el desarrollo embrionario del cerebro", realizada bajo su dirección por el Licenciado en Biología y Bioquímica D. Alejandro García García en el Departamento de Bioquímica y Biología Molecular de la Universidad de Salamanca.

Y para que conste, firman el documento en Salamanca a 29 de marzo de 2012.

Fdo. José María Medina Jiménez Fdo. Aránzazu Tabernero Urbieta

Fdo. Ana Purificación Velasco Criado

ILMO. SR. DIRECTOR DEL DEPARTAMENTO DE BIOQUÍMICA Y BIOLOGÍA MOLECULAR DE LA UNIVERSIDAD DE SALAMANCA. 



\section{ABREVIATURAS}

AFP: Alfa-fetoproteína

Ag: Amígdala

AMPS: persulfato amónico

$\mathrm{BHE}$ : barrera hematoencefálica

bHIH: basic Helix loop Helix

BHT: 2,6-di-ter-butil-4-metilfenol

BLBP: proteína de unión a ácidos grasos

BMP: proteína transformadora ósea (bone morphogenetic protein)

BrdU: bromo-deoxiuridina

BSA: albúmina sérica bovina

Cc: capa cortical

Ci: cápsula interna

CTA: córtico-talámicas (conexiones)

18-Crown: 1,4,7,10,13,16-hexaxociclooctadecano

DAPI: 4,6-diamidino-2-fenilindol dihidrocloruro

DIV: días in vitro

DMEM: medio de Eagle modificado por Dulbecco

DNA: ácido desoxirribonucleico

DTT: ditiotreitol

$\mathrm{E}$ : día embrionario

EGL: eminencia ganglionar lateral

EGM: eminencia ganglionar media

GABA: ácido gamma-aminobutírico

GAP-43: proteína asociada al crecimiento 43

GAPDH: gliceraldehído-3-fosfato deshidrogenasa

GFAP: proteína ácida fibrilar glial

HPLC: (High performance liquid chromatography) cromatografía líquida de alta eficacia.

IGF: (Insulin-like growth factor) factor de crecimiento insulínico

kDa: kilodalton

LCR: líquido cefalorraquídeo

MAP-2: proteína asociada a microtúbulos 2

mRNA: ácido ribonucleico mensajero

MTT: 3-(4,5-dimetiltiazol-2-il)-2,5-difenil-tetrazolio

$\mathrm{N}-\mathrm{CAM}$ : molécula de adhesión celular neuronal

Ncx: neocórtex.

NGF: factor de crecimiento nervios

NRT: Núcleo reticular talámico

$\mathrm{P}$ : día postnatal

$\mathrm{p} / \mathrm{v}$ : peso/volumen

PBPB: 2,4-dibromoacetofenona

PBS: tampón fosfato salino

Pc: Placa cortical

PKC: proteína kinasa $\mathrm{C}$

Pxc: Plexo coroideo.

PMSF: fenil metil sulfonil fluoruro

PPARs: receptores activados por proliferadores de peroxisomas

$\mathrm{RE}$ : retículo endoplasmático 
RNA: ácido ribonucleico

SCD: estearil-CoA desaturasa

SDS: dodecilsulfato sódico

SEM: error estándar de la media

SNC: sistema nervioso central

SNP: sistema nervioso periférico

SP: Subplaca

SREBP: proteína que se une al elemento regulado por estrógenos

SSC: tampón citrato sódico

Str: núcleo estriado

TAC: Tálamo-corticales (conexiones)

TBS: tampón Tris salino

TEMED: N,N,N',N'.tetrametiletilendiamina

TUNEL: marcaje de extremos mellados con dUTP mediado por la

desoxinucleotidil transferasa terminal (terminal transferase-mediated dUTP Nick

End Labelling)

VI: ventrículo lateral

WB: transferencia tipo Western (western-blot)

ZSV: Zona sub-ventricular.

ZV: zona ventricular 


\section{ÍNDICE}

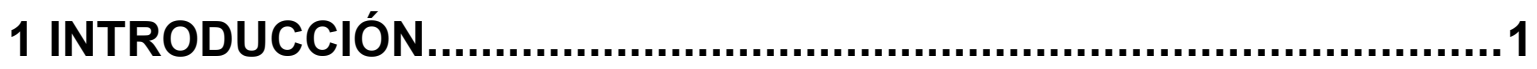

\subsection{COMPONENTES CELULARES DEL SISTEMA NERVIOSO}

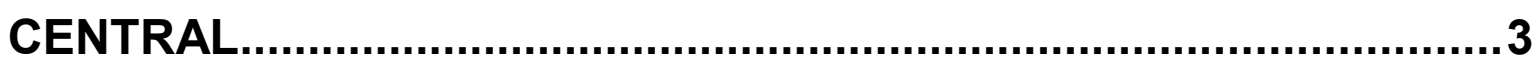

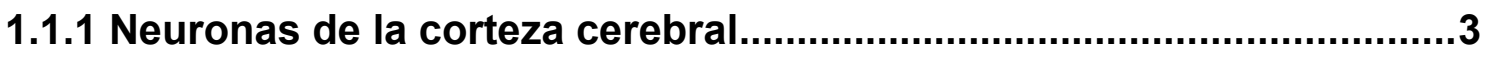

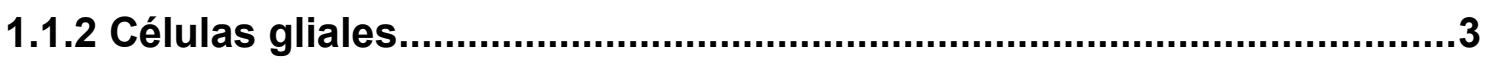

1.2 DESARROLLO DEL SISTEMA NERVIOSO DURANTE LA ETAPA

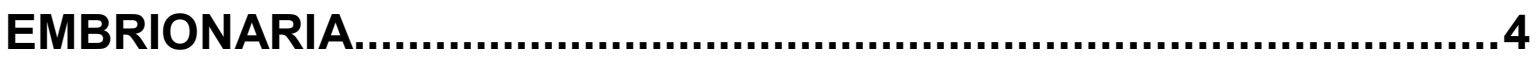

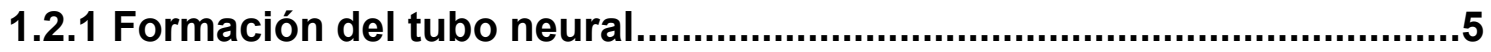

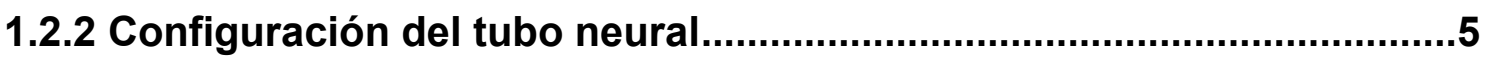

1.2.3 Células madre neuronales y progenitores celulares..............................8

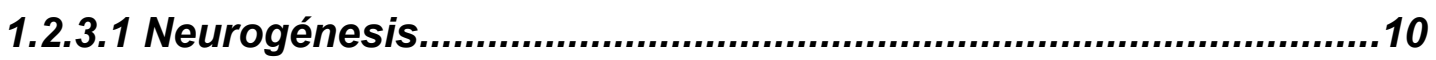

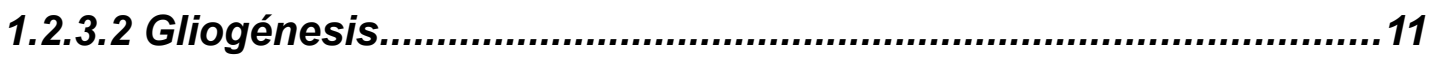

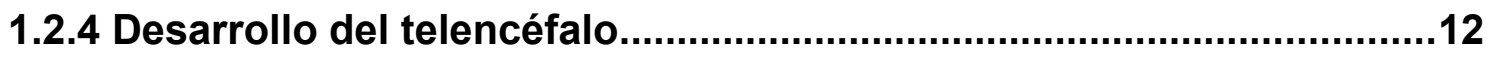

1.2.4.1 Desarrollo del neocórtex.............................................................12

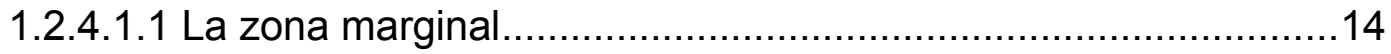

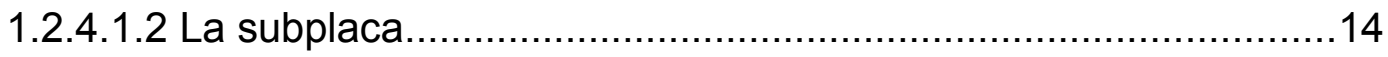

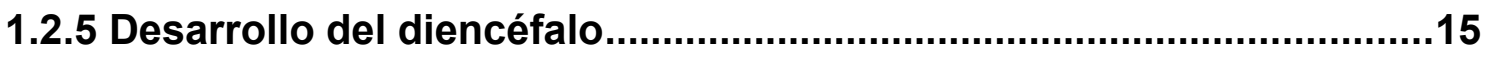

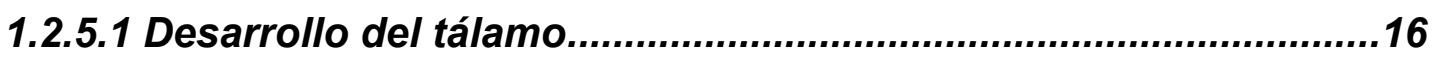

1.2.5.1.1 Conexiones tálamo-corticales y córtico-talámicas......................17

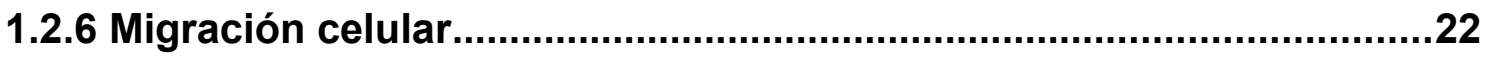

1.2.6.1 Migración radial...............................................................................22

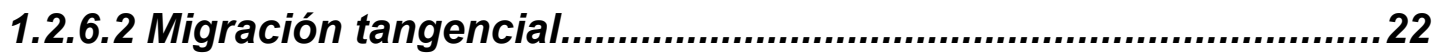

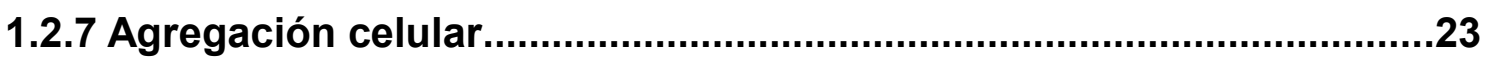

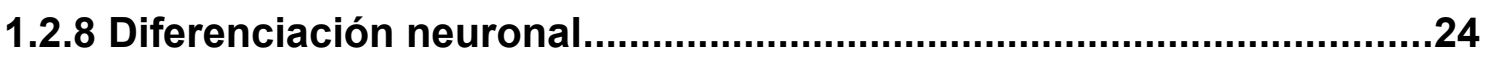

1.2.8.1 Proteína asociada al crecimiento, GAP-43................................26

1.2.8.2 Proteína asociada a microtúbulos, MAP-2................................28

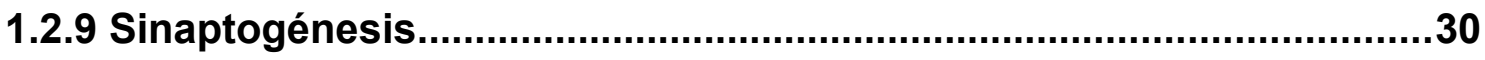

1.2.10 Muerte neuronal durante el desarrollo............................................31

1.3 PROTEÍNAS PLASMÁTICAS Y LÍQUIDO CEFALORRAQUÍDEO

EN EL DESARROLLO DEL ENCÉFALO.......................................32

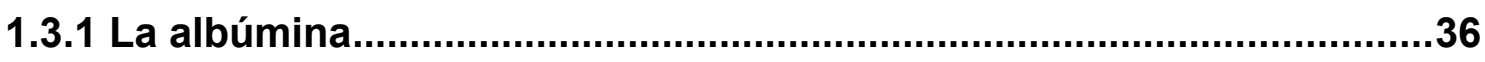


1.3.1.1 Estructura y principales funciones de la albúmina. 37

1.3.1.2 La albúmina en el cerebro...........................................................39

1.3.1.3 La albúmina y el factor neurotrófico ácido oleico........................40

1.3.1.4 Relevancia clínica de la albúmina...............................................43

1.3.1.5 Transporte de la albúmina en el cerebro......................................44

1.3.2 La alfa-fetoproteína........................................................................45

1.3.2.1 Estructura y propiedades de la alfa-fetoproteína.........................46

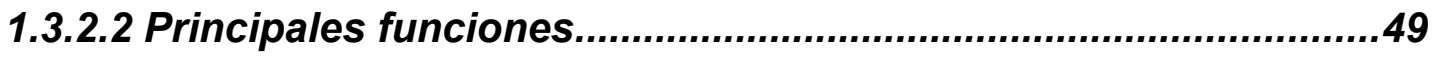

1.3.2.2.1 Transporte de ligandos......................................................50

1.3.2.2.2 Efecto de la alfa-fetoproteína sobre el crecimiento..................51

1.3.2.3 La alfa-fetoproteína en el cerebro.............................................52

1.3.2.4 Importancia clínica de la alfa-fetoproteína.................................53

2 PLAN DE TRABAJO..............................................................55

3 MATERIAL Y MÉTODOS.......................................................... 59

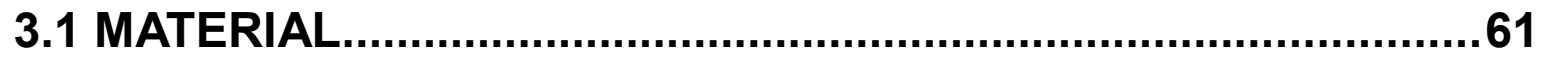

3.1.1 Especie ensayada y condiciones del animalario..............................61

3.1.2 Medios instrumentales.....................................................................62

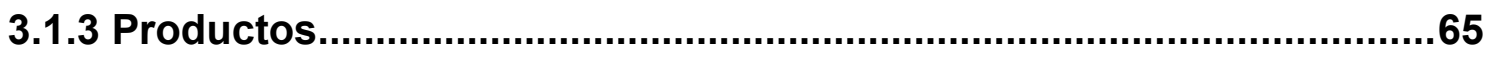

3.1.3.1 Productos utilizados para la preparación de los cultivos celulares

3.1.3.2 Productos utilizados para la preparación de los cultivos tisulares

3.1.3.3 Productos utilizados en la diálisis de la albúmina libre de ácidos grasos 66

3.1.3.4 Productos utilizados para la preparación de la alfa-fetoproteína

3.1.3.5 Productos utilizados para el análisis de las proteínas................67

3.1.3.6 Productos empleados para el análisis de los ácidos grasos.....70

3.1.3.7 Productos empleados en la determinación de la viabilidad y proliferación celulares........................................................................71

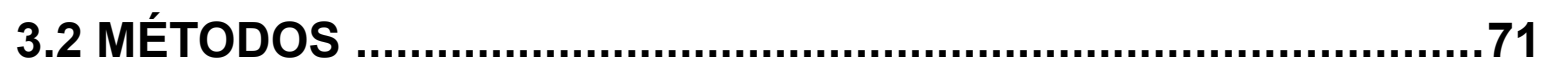

3.2.1 Preparación de los cultivos celulares ...............................................71

3.2.1.1 Preparación del cultivo primario de neuronas ...........................71 
3.2.1.2 Preparación del cultivo primario de astrocitos

3.2.1.3 Preparación del cultivo de células de hepatoma de rata McA-RH

7777. .74

3.2.2 Preparación de los cultivos tisulares .75

3.2.2.1 Preparación de los cultivos organotípicos de rodajas de cerebro 75

3.2.3 Preparación de la albúmina libre de ácidos grasos.............................76

3.2.4 Preparación y purificación de la alfa-fetoproteína...............................76

3.2.4.1 Material de partida.........................................................................76

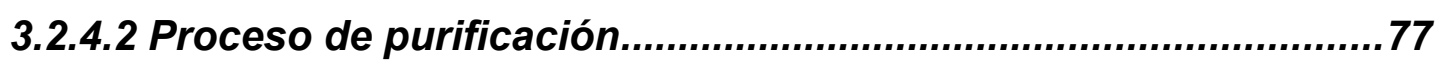

3.2.4.2.1 Concentración inicial.......................................................... 77

3.2.4.2.2 Retirada de la albúmina del medio......................................78

3.2.4.2.3 Segunda concentración de la alfa-fetoproteína........................80

3.2.4.2.4 Diálisis final de la alfa-fetoproteína.................................... 80

3.2.5 Tratamientos empleados en los cultivos .........................................81

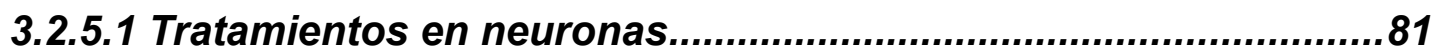

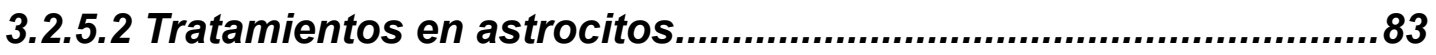

3.2.5.3 Tratamientos en cultivos organotípicos de rodajas de cerebro. 83

3.2.6 Determinación de la expresión de proteínas mediante análisis de transferencia tipo Western.........................................................................83

3.2.6.1 Análisis proteómico de la alfa-fetoproteína..................................87

3.2.7 Análisis de los ácidos grasos...........................................................88

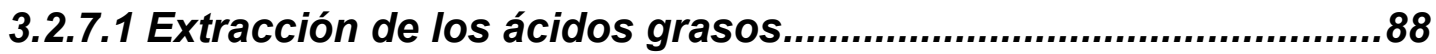

3.2.7.2 Derivatización de los ácidos grasos...........................................89

3.2.7.3 Método cromatográfico.............................................................90

3.2.7.4 Cuantificación de las áreas cromatográficas..............................90

3.2.8 Obtención y preparación de tejido nervioso fijado..............................90

3.2.8.1 Fijación de las neuronas en cultivo primario................................90

3.2.8.2 Fijación de cerebros embrionarios y fetales................................90

3.2.8.3 Fijación de cultivos organotípicos.............................................91

3.2.8.4 Obtención de los cortes histológicos ........................................91

3.2.9 Inmunofluorescencia.....................................................................92

3.2.10 Determinación inmunocitoquímica de la incorporación de BrdU....93

3.2.11 Estudio de la viabilidad celular. .94 
3.2.11.1 Determinación de la viabilidad celular mediante ensayo colorimétrico con MTT.

3.2.11.2 Determinación de la apoptosis tardía mediante la tinción tipo TUNEL (Terminal transferase-mediated dUTP Nick End Labelling).......94

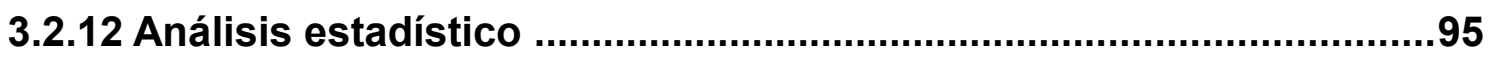

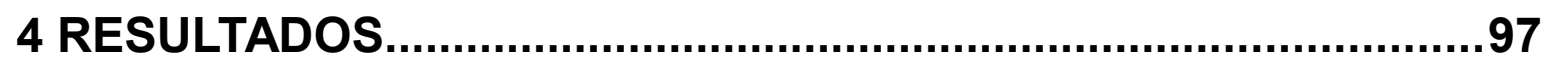

4.1 ESTUDIO DEL DESARROLLO EMBRIONARIO DEL CEREBRO

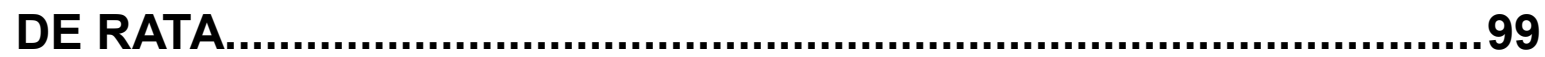

4.1.1 Determinación de la edad gestacional..............................................99

4.1.2 Estudio de los niveles de MAP-2 y GAP-43....................................100

4.1.3 Estudio de los niveles en cerebro de las proteínas plasmáticas albúmina y alfa-fetoproteína....................................................................101

4.1.4 Estudio de la concentración de ácido oleico libre en cerebro..........102

4.1.5 Relación entre el ácido oleico y la alfa-fetoproteína.........................103

4.1.6 Localización de las proteínas plasmáticas en el cerebro en desarrollo.

4.1.6.1 Localización en el cerebro embrionario de las proteínas plasmáticas AFP y albúmina en el día E19,5 de gestación....................103

4.1.6.1.1 Distribución de la AFP en el día E19,5..............................103

4.1.6.1.2 Distribución de la albúmina en el día E19,5 ..........................104

4.1.6.2 Distribución de las proteínas plasmáticas AFP y albúmina en el cerebro el día E15,5 de gestación............................................................ 105

4.1.6.2.1 Distribución de la AFP en el día E15,5.............................105

4.1.6.2.2 Distribución de la albúmina en el día E15,5 .........................106

4.1.6.3 Distribución de GAP-43 en el día E19,5 de desarrollo embrionario. 106

4.1.6.4 Distribución de GAP-43 en el día E15,5 de desarrollo embrionario. 107

4.1.6.5 Relación entre GAP-43 y AFP en el cerebro en desarrollo.........107

\subsection{OBTENCIÓN Y PURIFICACIÓN DE LA ALFA-FETOPROTEÍNA.}

4.2.1 Selección del material de partida. 110

4.2.2 Producción de AFP por parte de las células McA-RH 7777. 112 
4.2.3 Proceso de purificación.

4.2.4 Determinación de la pureza del resultado de la purificación.

\subsection{EFECTO DE LA ALFA-FETOPROTEÍNA EN EL SISTEMA} NERVIOSO CENTRAL EN DESARROLLO.

4.3.1 Efecto de la AFP sobre la morfología de las neuronas en cultivo primario.

4.3.2 Efecto de la AFP sobre la viabilidad neuronal..................................118

4.3.3 Efecto de la AFP sobre la proliferación neuronal in vitro 118

4.3.4 Efecto de las otras proteínas presentes como trazas en el purificado de AFP.

4.3.5 Efecto de la AFP desnaturalizada sobre la morfología y la viabilidad neuronales

4.3.6 Efecto de la AFP sobre los astrocitos.

4.3.7 Efecto de la AFP sobre la apoptosis neuronal in vitro. 120

4.3.8 Efecto de la AFP sobre la diferenciación neuronal.

4.3.8.1 Efecto de la AFP sobre la viabilidad neuronal en presencia del complejo albúmina-ácido oleico.

4.3.8.2 Efecto de la AFP sobre la diferenciación neuronal en cultivos primarios.

4.3.8.3 Efecto de la AFP sobre la diferenciación neuronal en cultivos organotípicos.

5 DISCUSIÓN.

5.1 Determinación de la edad gestacional..................................161

5.2 La alfa-fetoproteína en el cerebro embrionario.....................162

5.3 Obtención de la alfa-fetoproteína............................................171

5.4 Efecto de la alfa-fetoproteína sobre las neuronas.................172

6 CONCLUSIONES.....................................................................177

7 BIBLIOGRAFÍA.....................................................................181

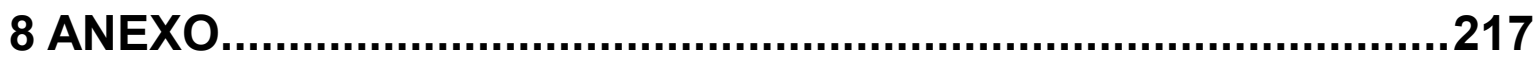




\section{Índice de figuras y tablas}

Esquema 1.- Organización celular del SNC ................................................................

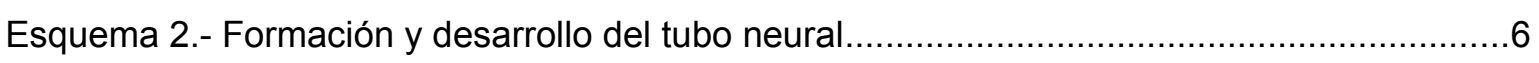

Esquema 3.- Organización del sistema nervioso durante la etapa embrionaria.......................

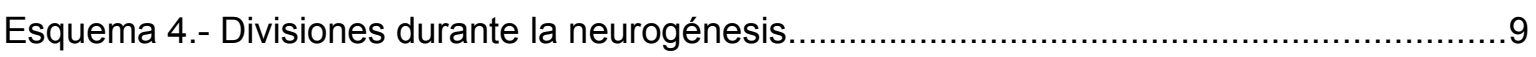

Esquema 5.- Desarrollo de las capas de corteza cerebral en la rata.....................................13

Esquema 6.- Establecimiento de las conexiones entre el tálamo y la corteza a lo largo del desarrollo.

Esquema 7.- Establecimiento de las conexiones entre el tálamo y la corteza a lo largo del desarrollo.

Esquema 8.- Tipos de migración de las neuronas de proyección y de las interneuronas de la corteza...

Esquema 9.- Localización inmunocitoquímica de las proteínas MAP-2 y GAP-43, en neuronas en cultivo primario. 29

Esquema 10.- Representación esquemática de las barreras del cerebro.

Esquema 11.- Comparación del desarrollo del cerebro en el ser humano y en la rata en etapas equivalen-tes del crecimiento embrionario.

Esquema 12.- Estructura terciaria de la albúmina. 38

Esquema 13.- Mecanismo propuesto de síntesis del ácido oleico en astrocitos y de su efecto neurotrófico en neuronas.

Esquema 14.- Estructura de la AFP. 48

Esquema 15.- Dispositivo de concentración del medio de hepatoma..................................78

Esquema 16.- Diagrama del proceso de purificación de la AFP.

Esquema 17.- Relación entre el peso fetal y el peso del cerebro a lo largo del desarrollo....163

Esquema 18.- Relación entre el desarrollo del cerebro con su contenido en AFP y ácido oleico libre

Esquema 19.- Relación entre la formación de las conexiones talamo-corticales y la localización de la AFP durante el desarrollo embrionario. 171

Tabla 1.- Anticuerpos primarios utilizados para la detección de proteínas en transferencia tipo western, inmunocitoquímica e inmunohistoquímica.

Tabla 2.- Anticuerpos secundarios utilizados para la detección de proteínas en transferencia 


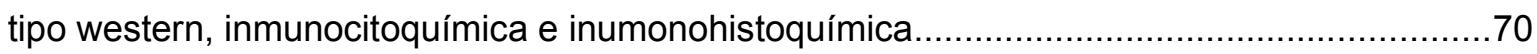

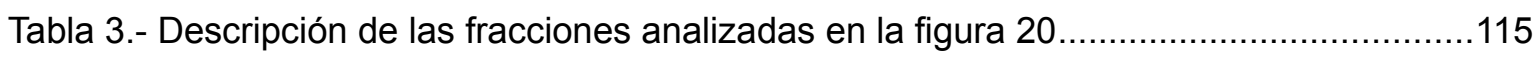

Figura 1.- Análisis de los diferentes valores biométricos a lo largo del desarrollo..................125

Figura 2.- Niveles de las proteínas MAP-2 y GAP-43 a lo largo del desarrollo embrionario del cerebro.

Figura 3.- Evolución de los niveles de albúmina durante el desarrollo embrionario del cerebro

Figura 4.- Evolución de los niveles de alfa-fetoproteína durante el desarrollo embrionario del cerebro.

Figura 5.- Análisis de los principales ácidos grasos libres presentes en el cerebro a lo largo del desarrollo.

Figura 6.- Relación entre la alfa-fetoproteína y los ácidos grasos libres presentes en el cerebro durante el desarrollo...

Figura 7.- Distribución de la alfa-fetoproteína a lo largo del eje rostro-caudal el día E19,5 de desarrollo fetal.

Figura 8.- Detalle de la localización de la alfa-fetoproteína el día E19,5 de desarrollo fetal. .132

Figura 9.- Distribución de la albúmina a lo largo del eje rostro-caudal en el día E19,5 de desarrollo fetal.

Figura 10.- Detalle de la localización de la albúmina el día E19,5 de desarrollo fetal. 134

Figura 11.- Distribución de la alfa-fetoproteína a lo largo del eje rostro-caudal el día E1,5 de desarrollo embrionario.

Figura 12.- Detalle de la localización de la alfa-fetoproteína el día E15,5 de desarrollo embrionario. 136

Figura 13.- Detalle de la localización de la alfa-fetoproteína el día E15,5 de desarrollo embrionario.

Figura 14.- Distribución de la albumina el día E15,5 de desarrollo embrionario 138

Figura 15.- Distribución de GAP-43 en el día E19,5 de desarrollo fetal..... 139

Figura 16.- Distribución de GAP-43 en el día E15,5 de desarrollo fetal. 140

Figura 17.- Doble inmunohistoquímica confocal contra AFP y GAP-43 en el día E19,5 de desarrollo embrionario.

Figura 18.- Doble inmunohistoquímica confocal contra AFP y GAP-43 en el día E15,5 de desarrollo embrionario. 
Figura 19.- Producción de AFP por parte de la línea celular de Hepatoma de rata McAR$\mathrm{H} 7777$.

Figura 20.- Análisis del proceso de purificación de la alfa-fetoproteína. 144

Figura 21.- Análisis bidimensional del resultado de la purificación de la AFP 145

Figura 22.- Análisis proteómico de la AFP obtenida tras la purificación. 146

Figura 23.- Efecto de la AFP sobre las neuronas en cultivo primario 147

Figura 24.- Efecto de la AFP sobre la vibialidad de neuronas en cultivo primario 148

Figura 25.- Efecto de la AFP sobre la proliferación neuronal in vitro. 149

Figura 26.- Efecto de otras proteínas presentes como trazas en el purificado de AFP sobre la viabilidad neuronal in vitro 150

Figura 27.- Efecto de la AFP desnaturalizada y de la albúmina de rata sobre la supervivencia de neuronas en cultivo primario 151

Figura 28.- Efecto de la AFP sobre la viabilidad de los astrocitos en cultivo primario. 152

Figura 29.- Efecto de la AFP sobre la apoptosis de neuronas en cultivo primario. 153

Figura 30.- Efecto de la AFP sobre la viabilidad neuronal en presencia del complejo albúminaácido oleico 154

Figura 31.- Efecto de la AFP sobre la expresión de MAP-2 y GAP-43 en neuronas. 155

Figura 32.- Doble inmunocitoquímica de GAP-43 y MAP-2 en cultivos primarios de neuronas 156

Figura 33.- Efecto de la AFP sobre los niveles de GAP-43 en cultivos organotípicos de cerebro de rata en $\mathrm{E} 17,5$.

Figura 34.- Inmunohistoquímica contra GAP-43 en cultivos organotípicos de cerebros de E17,5. 158

Figura A1.- Doble inmunohistoquímica confocal contra AFP y GAP-43 en el día E19,5 de desarrollo embrionario.

Figura A2.- Doble inmunohistoquímica confocal contra AFP y GAP-43 en el día E15,5 de desarrollo embrionario. 220 


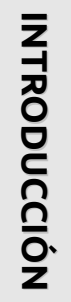




\subsection{COMPONENTES CELULARES DEL SISTEMA NERVIOSO CENTRAL.}

La totalidad de las funciones que posee el sistema nervioso adulto, como la memoria, la percepción sensorial o el control motor, dependen de la interacción precisa entre diferentes poblaciones de células nerviosas. Sin embargo, no fue hasta bien entrado el siglo XX, gracias a los trabajos de Santiago Ramón Cajal, que la comunidad científica aceptó la naturaleza celular del tejido nervioso. Hoy en día sabemos que las células del sistema nervioso central (SNC) pueden dividirse en dos grandes categorías: células nerviosas o neuronas, y células de la neuroglía (o simplemente glía).

\subsubsection{Neuronas de la corteza cerebral}

En la corteza cerebral se han descrito decenas de tipos neuronales atendiendo a su morfología y características. Sin embargo, a pesar de esta diversidad, las neuronas de la corteza cerebral de los mamíferos pueden agruparse en dos clases principales: las neuronas de proyección, también denominadas neuronas piramidales, y las interneuronas o neuronas de circuito local. Las neuronas de proyección son excitadoras y utilizan como neurotransmisor el glutamato; por el contrario, la mayoría de las interneuronas son inhibidoras y utilizan el ácido gamma-aminobutírico (GABA) como neurotransmisor principal (Marín 2002). En los últimos años se ha puesto de manifiesto que el funcionamiento de los circuitos corticales requiere la perfecta coordinación de las neuronas excitadoras y de las inhibidoras (McBain y Fisahn 2001).

\subsubsection{Células gliales}

Las células gliales o neuroglía representan el $90 \%$ del total de células del SNC. Inicialmente descritas como el cemento nervioso (Virchow 1858), las células de la glía constituyen un grupo heterogéneo de células que desarrollan importantes funciones para el funcionamiento del tejido nervioso. De manera clásica las células gliales se dividen en astrocitos, oligodendrocitos y células microgliales. 
Asimismo se incluyen dentro de la glía las células ependimales y las recientemente descritas células NG2 o polidendrocitos, precursoras de oligodendrocitos.

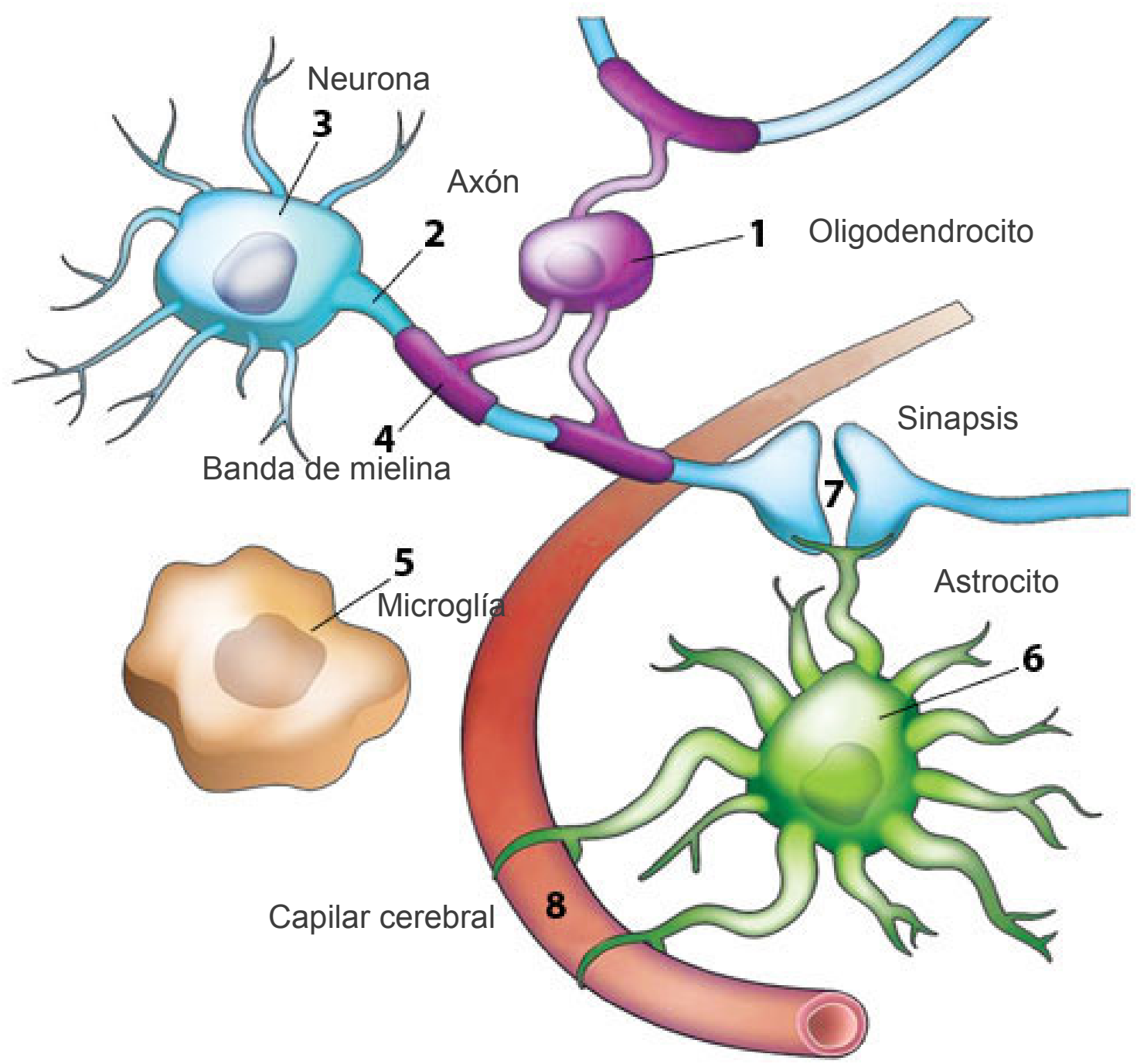

Esquema 1.- Organización celular del SNC. Existen cuatro tipos principales de células en el SNC: los oligodendrocitos, (1) que se encuentran formando la banda de mielina (4) que rodea los axones (2), las neuronas que llevan a cabo la transmisión del impulso nervioso (3), las células de la microglía (5) que llevan a cabo las funciones de sistema inmune en el SNC y los astrocitos (6) que se encuentran en estrecha relación con las sinapsis neuronales (7) y los capilares cerebrales (8). Esquema modificado de Goldman (Goldman 2009).

\subsection{DESARROLLO DEL SISTEMA NERVIOSO DURANTE LA ETAPA EMBRIONARIA}

El conjunto de etapas que comprende la formación y configuración del sistema nervioso determinará el correcto funcionamiento de éste durante la etapa adulta. 
En mamíferos, la formación de las estructuras cerebrales se produce mayoritariamente durante la etapa embrionaria del desarrollo, tanto en la especie humana (Monuki y Walsh 2001) como en la rata, que nos sirve de modelo para su estudio (Altman y Bayer 1994).

Conceptualmente, el desarrollo del sistema nervioso implica la consecución de una serie de hitos: inducción de la placa neural y formación del tubo neural; regionalización y configuración del tubo neural en prosencéfalo, mesencéfalo y rombencéfalo; generación de las neuronas y la glía a partir de sus progenitores, apoptosis, migración, sinaptogénesis y establecimiento de los circuitos neurales (Wigle y Eisenstat 2008).

\subsubsection{Formación del tubo neural}

El desarrollo del sistema nervioso comienza tras el proceso de gastrulación, a partir de la modificación y sucesiva evolución del ectodermo del embrión. Mediante este proceso se forma un epitelio denominado placa neural, que posteriormente comenzará a plegarse y a formar una estructura tubular denominada tubo neural, mediante un proceso denominado neurulación (esquema 2a). El tubo neural se encuentra formado por células altamente proliferativas, denominadas células neuroepiteliales o células madre neuronales, que darán lugar a todas las células del sistema nervioso central (SNC), neuronas y células macrogliales del SNC (astrocitos y oligodendrocitos).

La parte más caudal de éste tubo dará lugar al desarrollo de la médula espinal y la parte más rostral se reorganizará en tres regiones o vesículas diferenciadas, el prosencéfalo, el mesencéfalo, y el rombencéfalo. En la presente Memoria abordaremos el estudio de los fenómenos de desarrollo que implican a la región prosencefálica (esquema $2 b$ ).

\subsubsection{Configuración del tubo neural}

Una vez generado el tubo neural, éste queda configurado a lo largo del eje dorso-ventral por señales procedentes de tejidos no neurales. Así, la región ven- 
tral se configura principalmente mediante la proteína "Sonic Hedgehog" (Shh), producida por la notocorda, y la región dorsal queda configurada por la proteína BMP ("bone morphogenetic protein"), secretada por el ectodermo epidérmico y la placa tectal. Estas señales difunden a lo largo del eje dorso-ventral, generando un gradiente de concentración que configura el tubo neural, que se mantienen a lo largo del eje rostro-caudal generando diferentes tipos celulares (Kandel y col. 2001).

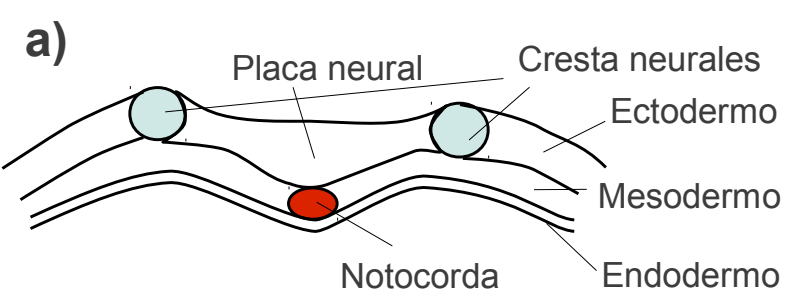

Surco neural
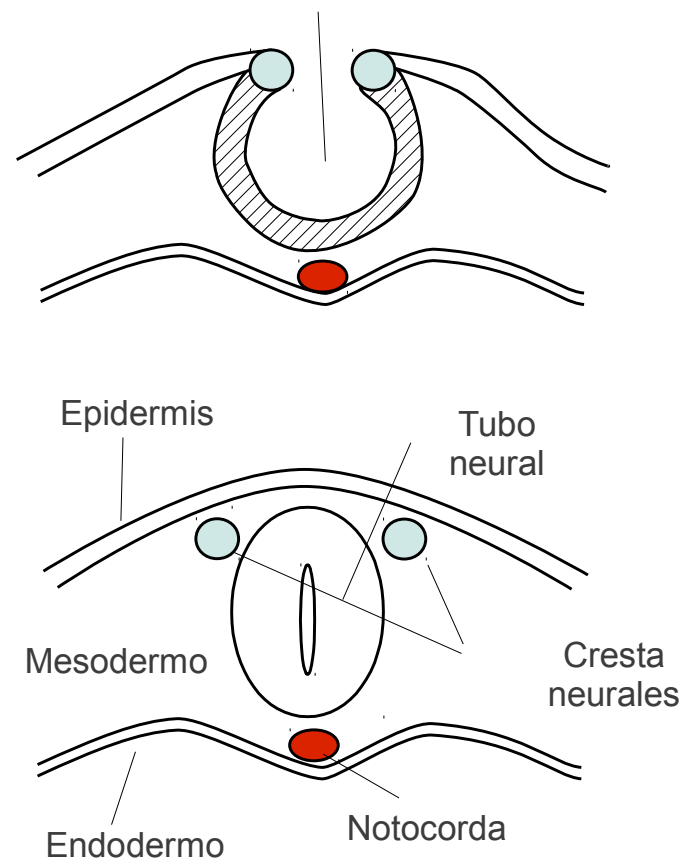

b)

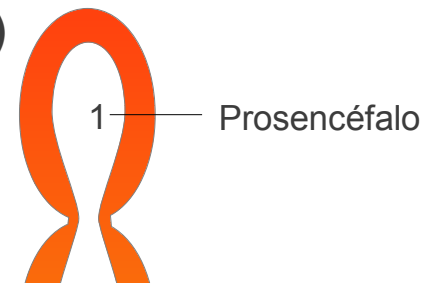

2 Mesencéfalo

$3-$ Rombencéfalo

Tubo neural caudal

Esquema 2.- Formación y desarrollo del tubo neural. a) Proceso de neurulación o formación del tubo neural a partir de las células del ectodermo. b) Estadío de tres vesículas del tubo neural.

Asimismo, el tubo neural queda configurado a lo largo del eje rostro-caudal por diferentes señales, como el ácido retinoico (RA), la expresión del gen "wingless type" (Wnt), la expresión de genes homeobox o factores de transcripción, incluidos genes de la familia bHLH (basic helix-loop-helix), quedando el tubo dividido 
en prosencéfalo, mesencéfalo y rombencéfalo.

Se conoce desde hace tiempo que la diferenciación de cada una de las estructuras de las regiones del sistema nervioso depende de la expresión de genes concretos, que dividen cada una de estas regiones en unidades segmentarias (Kandel y col. 2001). La búsqueda de un modelo equivalente a la expresión de los genes Hox que regulan el desarrollo del rombencéfalo, llevó a Rubstein y colaboradores a proponer el modelo prosomérico (Rubenstein y col. 1994) y a su posterior revisión (Puelles y Rubenstein 2003).

a)

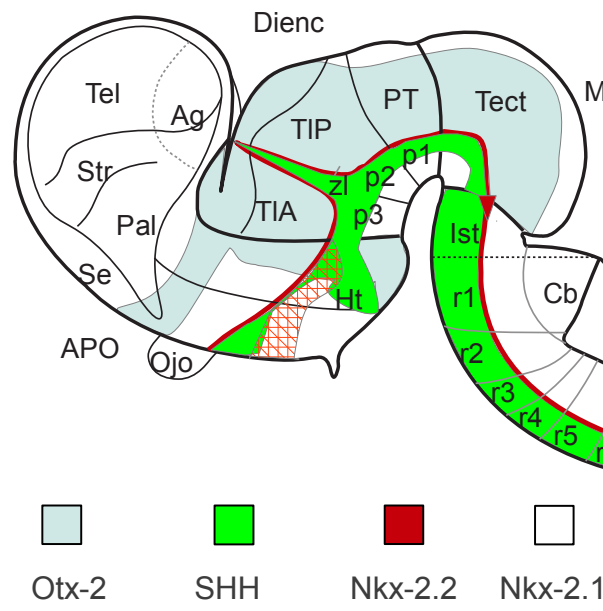

b) Neocórtex

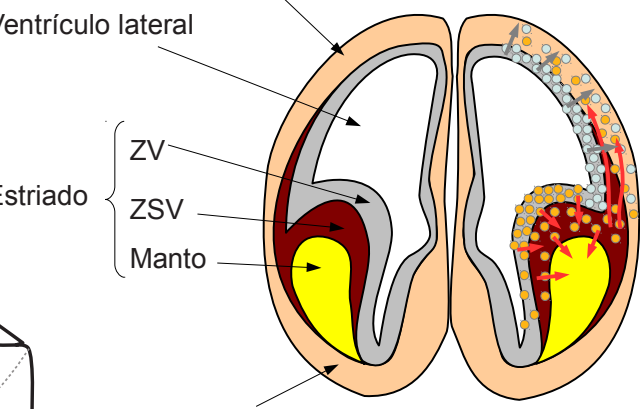

Paleocórtex

Esquema 3.- Organización del sistema nervioso durante la etapa embrionaria. a) Representación gráfica del modelo prosomérico (modificado de Rubenstein y Puelles (Rubenstein y col. 1994; Puelles 2009))Los colores representan la expresión local de genes implicados en el desarrollo. Abreviaturas: Tel., telencéfalo; Str, estriado; Ag, amígdala; Pal, pálido; APO, área pre-óptica; TIA, tálamo anterior; Ht, hipotálamo; zl, zona llimitante; TIP, tálamo posterior; Dienc, diencéfalo; PT, pretectum; Tect, tectum; Mes, mesencéfalo; Ist, istmo; Cb, cerebelo; p1-p3, prosómeros 1 al 3; Rb, rombencéfalo; r1-r11, rombómeros 1 al 11; ME, médula espinal. b) División longitudinal del tubo neural en zona ventricular (ZV), zona subventricular (ZSV) y manto. Los progenitores neurales se generan en la zona ventricular y migran (flechas) radialmente o tagencialmente hacia sus diferentes destinos. Esquema modificado de Kandel (Kandel y col. 2001).

El modelo prosomérico (ver esquema 3a) consiste en un modelo estructural segmentario, que define el tubo neural de los vertebrados en una serie de subunidades transversales, denominadas generalmente neurómeros. Entre esas subunidades encontramos una gran subunidad frontal denominada prosencéfalo secundario, formada por el hipotálamo, los ojos y el telencéfalo. A continuación en el prosencéfalo más caudal encontramos una serie continua de tres "prosómeros" o 
neurómeros diencefálicos (p1-p3), que comprenden el pre-tectum, el tálamo y el pre-tálamo, considerados homólogos a los neurómeros más caudales (rombómeros).

A su vez, el tubo neural se encuentra dividido longitudinalmente en tres zonas: la zona ventricular (VZ), que se encuentra adyacente a la superficie del ventrículo y es donde se generan la mayoría de los progenitores neurales; la zona subventricular (ZSV) y la zona del manto (M) (esquema 3b).

\subsubsection{Células madre neuronales y progenitores celulares}

Se denominan células madre neurales (CMN) a aquellos linajes de células progenitoras que darán lugar, en última instancia, a la formación de neuronas diferenciadas o de células gliales (Kriegstein y Alvarez-Buylla 2009). Se aplican dos criterios para definir una célula como célula madre: autorrenovación, para un número ilimitado de divisiones celulares y multipotencialidad, la capacidad de generar diferentes tipos de células diferenciadas. La multiplicidad puede ocurrir tanto por divisiones simétricas, generando dos células totalmente iguales, como asimétricas, produciendo una célula que es idéntica a la madre y una segunda de diferente tipo celular. En el esquema 4 a se representan este tipo de divisiones en las principales áreas proliferativas del SNC durante el desarrollo, la zona ventricular (ZV) y la zona subventricular (ZSV) (Götz y Huttner 2005). En función de sus características y polaridad, se definen dos grandes grupos de progenitores (Fietz y Huttner 2011).

- Progenitores bipolares: Se trata de las células neuroepiteliales y de las células de la glía radial. Los progenitores bipolares son células que poseen un extremo apical de su membrana pegado a la superficie ventricular mediante uniones adherentes y un proceso basal en contacto con la lámina basal. Estas células sufren un proceso denominado migración intercinética nuclear, según la cual la mitosis de estas células se da en el extremo apical y posteriormente, el núcleo se desplaza hacia la cara basal. En conjunto, estas células se conocen como progenitores apicales. Se dividen principalmente de manera asimétrica, pero también sufren divisiones simétricas. 
a)

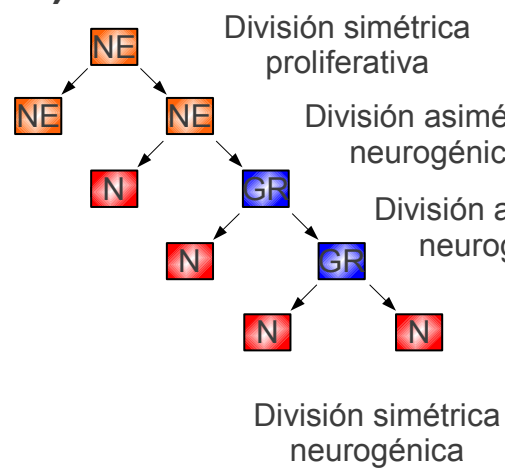

b)

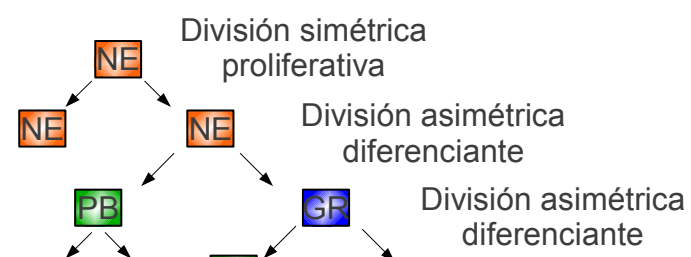

c)

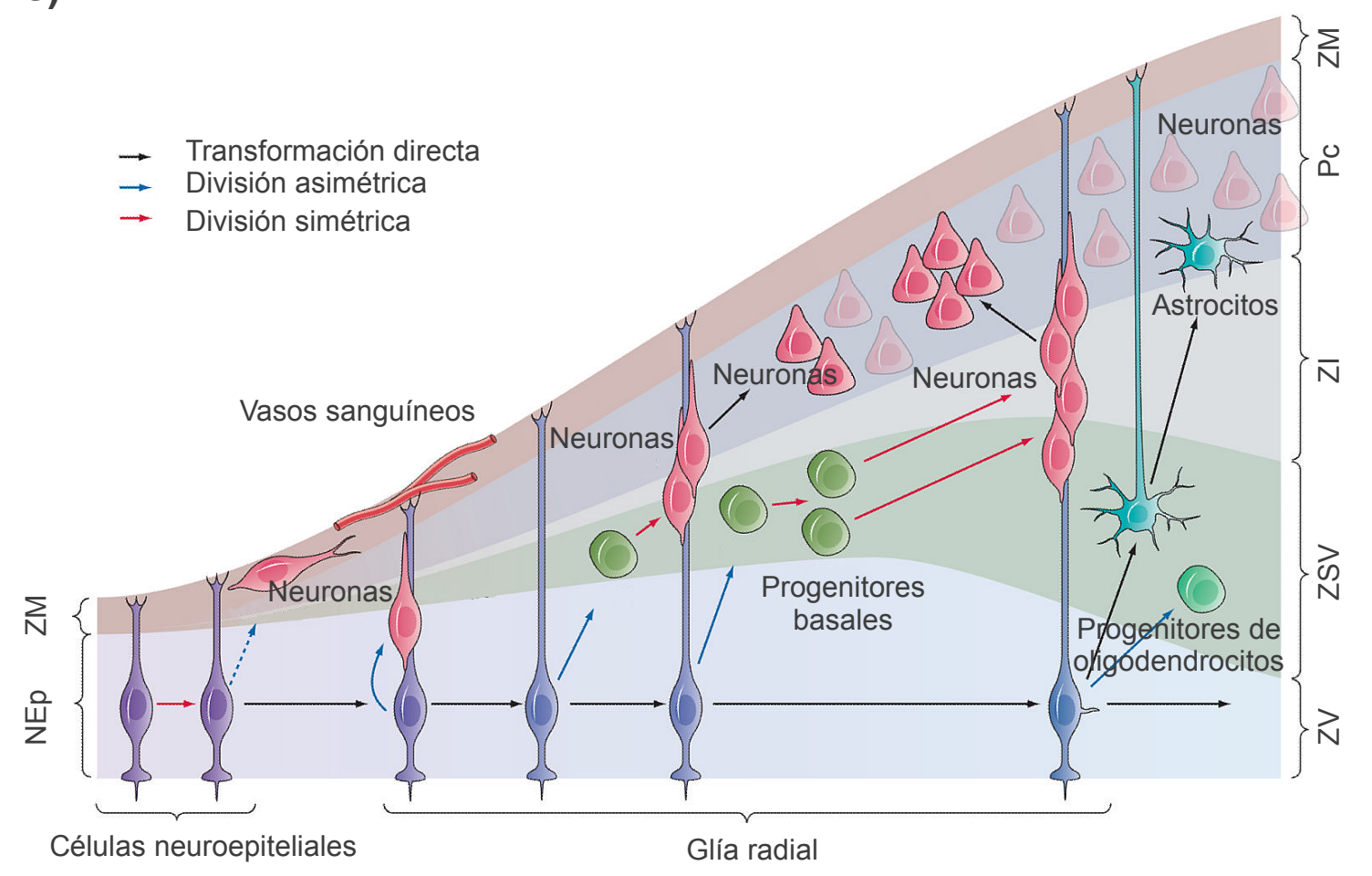

Células neuroepiteliales

División simétrica neurogénica

División simétrica neurogénica

GP División simétrica

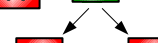
diferenciante
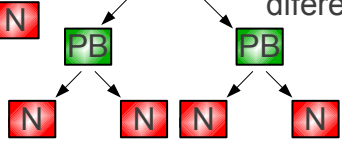

Divisiones simétricas neurogénicas

Esquema 4.- Divisiones durante la neurogénesis. a) y b) En estos esquemas se representan de manera resumida las divisiones que tienen lugar durante el desarrollo embrionario en la zona ventricular (VZ) (a) y en la zona subventricular (SVZ) (b). Abreviaturas: NE, células neuroepiteliales, GR, células de la glía radial, PB, progenitores basales y N, neuronas. Esquema modificado de Götz y Huttner (Götz y Huttner 2005) c) Generación de la progenie neural y glial a partir de tres progenitores distintos (NE, GR, PB) durante el desarrollo cortical. Esquema modificado de Kriegstein y Alvarez-Buylla (Kriegstein y Alvarez-Buylla 2009). 
- Células neuroepiteliales: Antes del comienzo de la neurogénesis, todo el neuroepitelio de la placa neural y del tubo neural se encuentra formado por una única capa germinativa que formará la zona ventricular (ZV).

- Glía radial (GR): Con el comienzo de la neurogénesis, las células neuroepiteliales disminuyen la expresión de ciertas características epiteliales y comienzan a expresar caraterísticas astrogliales. Se generan entonces un tipo de células distintas, denominadas glía radial, que presentan características neuroepiteliales, como la migración intercinética nuclear, y astrogliales, como la expresión de marcadores típicos de estas células como son el transportador de glutamato GLAST, la proteína de unión a calcio $S 100 \beta$, la proteína ácida fibrilar de la glía (GFAP), la vimentina o la proteína de unión a lípidos cerebral (BLBP). Se ha demostrado que las células de la glía son capaces de sufrir divisiones asimétricas renovadoras dando lugar a neuronas o a otro tipo de progenitores neurales. Por tanto las células de la glía radial pueden ser consideradas igualmente como células madre neurales (Farkas y Huttner 2008). De hecho, se puede considerar a las células de la glía radial y a una subpoblación de astrocitos durante la etapa adulta, como los progenitores de la mayoría, si no de todos, los linajes neurogénicos del SNC (Kriegstein y Alvarez-Buylla 2009)

- Progenitores no polares: En este grupo se incluyen los progenitores basales (PB) o progenitores intermedios, descritos en los roedores y los progenitores de la zona subventricular interna (ZSVI), descritos en humanos y mustélidos. Los progenitores basales se originan a partir de los progenitores apicales y se definen como células cuya mitosis se produce fuera de la zona ventricular, sin procesos apicales y que poseen un proceso basal durante la fase $\mathrm{M}$ del ciclo celular. Las progenitores basales se dividen simétricamente para generar dos progenitores basales más o dos neuronas.

\subsubsection{Neurogénesis}

El período de neurogénesis es diferente en cada especie. En el hombre la mayor parte de las neuronas se generan entre los días 40 y 125 de la gestación (Rakic 1978), mientras que en el ratón ocurre entre los días 11 y 17 de la gestación (Caviness y Takahashi 1995) y en la rata comienza el día 13 y finaliza el día 19 de 
la gestación (Gohlke y col. 2004). Comparativamente, la neurogénesis en la rata tiene lugar en un período de gestación posterior al que se produce en el hombre. Las implicaciones de esta neurogénesis temprana en el hombre no se conocen, pero existe la posibilidad de que las neuronas necesiten un período largo de adaptación al medio para poder ejercer funciones altamente especializadas, como son la memoria, el aprendizaje, etc (Rakic 1985). Sin embargo, para una misma especie animal, el período de proliferación neuronal depende de la región del SNC (Bayer 1995). Así, por ejemplo, en el hipocampo de la rata el número de neuronas sigue aumentando hasta el primer año de vida postnatal (Herschkowitz 1988). Las neuronas se generan a partir de las células madre neurales, es decir, las células neuroepiteliales, las células de la glía radial y los progenitores intermedios (ver sección 1.2.3. y esquema 4). En los mamíferos, durante la vida adulta la generación de nuevas neuronas se produce a partir de células progenitoras con características astrogliales (Kriegstein y Alvarez-Buylla 2009).

\subsubsection{Gliogénesis}

Durante el pasado siglo se asumía que las neuronas derivaban de progenitores especializados denominados neuroblastos y que las células gliales provenían de progenitores diferentes denominados espongioblastos (lo que hoy conocemos como glía radial). Hoy en día, sin embargo, sabemos que las células de la glía radial dan lugar a la práctica totalidad de las neuronas y las células gliales. Sin embargo, dentro de estas células existen progenitores multipotenciales capaces de dar lugar a todo el linaje nervioso (neuronas, astrocitos y oligodendrocitos), y progenitores restringidos para cada uno de los tipos celulares posibles.

Al final del período de corticogénesis, las células de la glía radial se sueltan de la cara ventricular y migran hacia la placa cortical. En los mamíferos, la mayoría de las células de la glía radial se transforman entonces en astrocitos; esta transformación continúa durante el periodo postnatal. Sin embargo, algunos astrocitos pueden dividirse antes de su diferenciación final, dando lugar a un tipo de progenitores intermedios astrocitarios. Curiosamente, los astrocitos corticales siguen un patrón laminar similar al de las neuronas, con los astrocitos más tardíos colocados en las capas más exteriores de la corteza (para una revisión más extensa del ori- 
gen de las células gliales ver Kriegstein y Alvarez-Buylla 2009).

\subsubsection{Desarrollo del telencéfalo}

\subsubsection{Desarrollo del neocórtex}

La mayor parte de las neuronas corticales se generan en el epitelio pseudoestratificado que limita las cavidades ventriculares del tubo neural, en la zona ventricular (ZV). Existe, además, una población proliferativa secundaria que incluye progenitores localizados en la zona subventricular (SVZ) (Bayer y Altman 1991) ver sección 1.2.3)

Existen tres gradientes neurogénicos durante el desarrollo de la corteza cerebral: radial, medio-lateral y antero-posterior (Bayer y Altman 1991). Radialmente, la corteza se organiza de forma que las neuronas que nacen primero ocupan posiciones más profundas respecto a las que nacen posteriormente (Rakic 1974; Susan K. 1988). A este gradiente también se le conoce como patrón de neurogénesis de dentro hacia fuera. Además, se ha descrito que las neuronas que se originan en las regiones laterales de la corteza se desarrollan antes que aquéllas que lo hacen en regiones más mediales. Lo mismo ocurre con las regiones anteriores respecto de las posteriores (Bayer y Altman 1991).

En el ratón, la actividad neurogénica de la ZV se extiende durante siete días, iniciándose el día embrionario E11 y finalizando en el día E17 (Caviness y Takahashi 1995). En la rata este periodo se encuentra retrasado dos días, transcurriendo entre E13 y E19 (Gohlke y col. 2004).

En la rata, antes de E13 el neocórtex se encuentra formado por una única capa de células que comprenden el neuroepitelio (NE). Entonces, en torno a E13 un conjunto de células postmitóticas abandonan la ZV y migran radialmente hacia la superficie pial, estableciendo una capa conocida como preplaca (PP). Posteriormente, en torno a E15, una segunda oleada de células postmitóticas migra hacia la preplaca, creando una capa que divide la PP en zona marginal (ZM) y subplaca $(\mathrm{SP})$. Ambas son capas transitorias que delimitan la futura placa cortical (Pc) y son de suma importancia para la correcta formación de las diferentes capas corti- 
cales. Así, entre E15 y E18, las neuronas generadas por los progenitores de la ZV, la glía radial y las células neuroepiteliales, forman las capas inferiores $\mathrm{V}$ y VI de la placa cortical, mientras que las neuronas generadas por los progenitores de la ZSV, los progenitores intermedios, formarían las capas superiores II a IV de la PC (Molyneaux y col. 2007). Éstas células migran radialmente atravesando la zona intermedia (ZI) y SP para situarse en su capa cortical correspondiente (ver esquema $5)$.

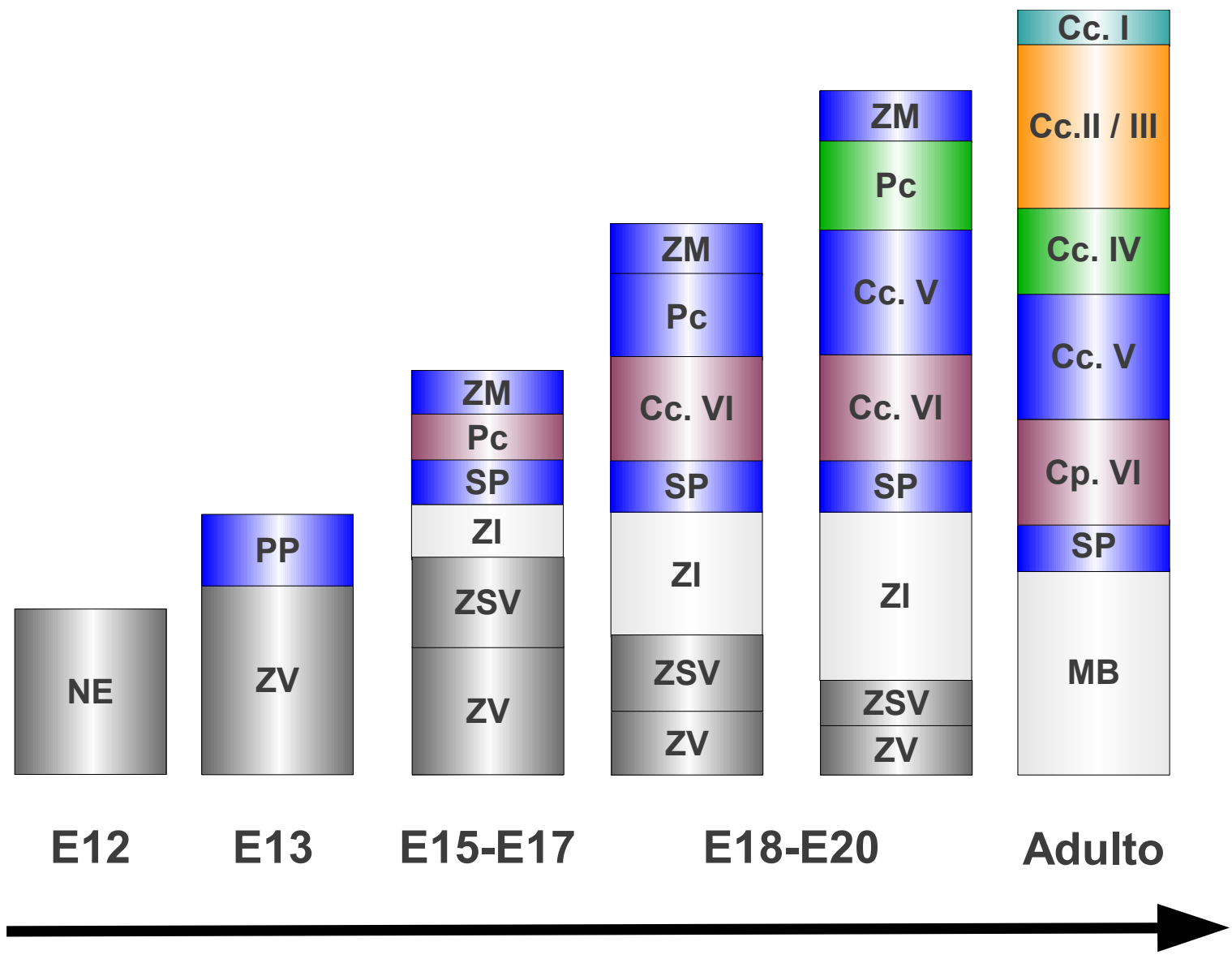

Esquema 5.- Desarrollo de las capas de la corteza cerebral en la rata. En la rata, las primeras neuronas se generan el día 13 de gestación, a partir del neuroepitelio (NE) y forman una capa denominada preplaca (PP). A continuación, las neuronas generadas forman la placa cortical (Pc), que divide la preplaca en una zona marginal (ZM) y en la subplaca (SP). Los axones de estas neuronas, junto con los axones en crecimiento desde el tálamo, establecen la zona intermedia (ZI). Las neuronas generadas por los progenitores de la zona ventricular (VZ), la glía radial y las células neuroepiteliales, forman las capas inferiores $\mathrm{V}$ y VI de la placa cortical, mientras que las neuronas generadas por los progenitores de la zona subventricular (SVZ), los progenitores intermedios, forman las capas superiores II-IV de la CP. La zona marginal origina la capa superior I de la CP, que se convierte en la sustancia gris de la corteza cerebral en el organismo adulto y las VZ y SVZ prácticamente desaparecen, quedando los haces de fibras que conforman la materia blanca (MB). Esquema modificado de O'Leary y de Molyneaux ((O'Leary y Koester 1993; Molyneaux y col. 2007). 


\subsection{La zona marginal}

La ZM formará la futura capa I del neocórtex y en ella encontramos las células de Cajal-Retzius (CR). Estás células son neuronas principalmente glutamatérgicas, bipolares o multipolares, distribuidas horizontalmente y que poseen numerosas dendritas y un axón descendente que emite numerosos colaterales, mediante los cuales contactan con neuronas piramidales de la corteza, así como con las neuronas GABAérgicas de la ZM (Sarnat y Flores-Sarnat 2002; Soriano y Del Río 2005). Su papel es fundamental para el desarrollo de la placa cortical puesto que fallos en estas células están implicados en patologías graves tales como la esquizofrenia, la epilepsia o el autismo. Son de las primeras neuronas en formarse y establecer cirtcuitos neuronales en el cerebro, pero son neuronas de naturaleza transitoria (un $95 \%$ mueren por apoptosis en la primera semana postnatal en los roedores (Luhmann 2003; Soriano y Del Río 2005)). Su importancia radica en la expresión de genes claves para la formación y maduración del neocórtex, como LIS1 y reelina. La reelina es una glicoproteína que es sintetizada y secretada por las células de Cajal-Retzius. Está implicada en la polimerización e inhibición de la despolimerización de los microtúbulos y su mecanismo de acción se realiza a través de los receptores ApoE-R2 y VLDLR y la proteína adaptadora DAB-1. Entre las numerosas funciones atribuidas a esta proteína destacan la formación del andamiaje de las células de la glía radial, la regulación de la interacción entre neuronas y glía radial, tanto en la unión como en su posterior separación, la división de la preplaca y la inducción de la migración de la migración radial (para una revisión ver Herz y Gupta (Gupta y col. 2002; Herz y Chen 2006).

\subsection{La subplaca}

La subplaca es una capa de naturaleza transitoria, que se encuentra por debajo de la Pc y por encima de la zona intermedia (ZI). Esta capa posee una importancia vital en el correcto desarrollo de la capa cortical. Sus neuronas son de las primeras en formarse, junto a las células de Cajal-Retzius (Bayer y Altman 1990), y son las primeras en establecer circuitos y sinapsis en la Pc, tanto GABAergicas como glutamatérgicas. Las dendritas de estas células establecen conexiones sinápticas con las neuronas de las placas corticales y de la ZM y presentan proyec- 
ciones radiales a lo largo de la $\mathrm{Pc}$, así como proyecciones más largas que establecen conexiones con el tálamo. Además, estas neuronas establecen sinapsis eléctricas a través de "gap-junctions" formando un sincitio funcional a lo largo de toda la placa. Entre sus numerosas funciones destacan la formación de los circuitos tálamo-corticales y córtico talámicos (López-Bendito y Molnár 2003) y la maduración del circuito inhibidor de la placa IV en las áreas inervadas por el tálamo.

De manera clásica se ha descrito en la SP un "periodo de espera" que facilita el correcto establecimiento de los circuitos neuronales. El tiempo de espera es diferente según las especies y mayor en primates. En la rata, a pesar de haber sido cuestionado por algunos autores, este periodo de espera se encontraría en torno a los días E17 y E19 (Lund y Mustari 1977; Molnár y col. 1998; López-Bendito y Molnár 2003; Kanold y Luhmann 2010). Hoy en día se considera a SP como una centro de integración de señales que se distribuirán a la largo de la Pc. Por último, la SP está implicada, junto a la glía radial, en la formación de la correcta arquitectura cortical (columnas corticales).

Cabe destacar, que si bien tradicionalmente se considera a la SP como una población neuronal transitoria que desaparece mediante apoptosis postnatal (Luhmann 2003), se ha demostrado que en los roedores, la apoptosis en la SP no es mayor que en otras placas corticales, permaneciendo células de la SP presentes en la materia blanca del cerebro en el organismo adulto (Valverde y col. 1995; Robertson y col. 2000; Montiel y col. 2011). Sin embargo, en los primates y concretamente en humanos, la persistencia de estas células durante la vida adulta ha sido vinculada con enfermedades de la señalización inhibitoria como la esquizofrenia y el autismo (para una revisión más extensa de la subplaca ver Kanold y Luhmann 2010).

\subsubsection{Desarrollo del diencéfalo}

El diencéfalo se encuentra subdividido en dos regiones principales, el tálamo y el hipotálamo. El tálamo se encarga de la interconexión y modulación de la información sensitiva (no olfatoria) obtenida por los receptores con las regiones telencefálicas encargadas del procesamiento de esa información. Asimismo, el tálamo 
participa en la integración de la información motora que llega desde el cerebelo y los ganglios basales (como el núcleo estriado) y en la transmisión de esa información a las regiones motoras de los hemisferios cerebrales.

Por otro lado, el hipotálamo, que se sitúa ventralmente en relación al tálamo, regula numerosos comportamientos y es esencial para la homeostasis del organismo y para la reproducción. Por ejemplo, entre otras muchas funciones, el hipotálamo controla el crecimiento, la alimentación y el comportamiento materno, mediante la secrección de hormonas en la glándula pituitaria. El hipotálamo también regula los ritmos circadianos, controla aspectos del comportamiento y posee conexiones con prácticamente cualquier región del sistema nervioso.

Durante el desarrollo del tubo neural, encontramos una región denominada zona limitante, que define la separación entre los prosómeros 2 y 3 (ver esquema 3; zl: zona limitante). Esta zona contiene una serie de células que conformarán el organizador medial-diencefálico. Este organizador regula mediante la secreción de Shh (esquema 3, en verde) y la expresión de miembros de la familia génica Wnt y Fgf la organización antero-posterior del tálamo y el hipotálamo.

\subsubsection{Desarrollo del tálamo}

El tálamo y la corteza se desarrollan al mismo tiempo, de manera sincronizada. La mayoría de las neuronas talámicas se generan entre E13 y E19, lo que coincide con el periodo de neurogénesis en la corteza (Altman y Bayer 1979). Alrededor de E13 comienza a desarrollarse en la pared del diencéfalo el futuro tálamo y su división en tálamo dorsal y ventral. Posteriormente, en torno a E16-E17, comienza la diferenciación de los núcleos talámicos, empezando en el epitálamo y el tálamo ventral y por último el tálamo dorsal. El núcleo reticular talámico (NRT) es considerablemente más grande durante el desarrollo y un gran número de células de esta estructura desaparecen durante la vida adulta. Esta estructura se ha llegado a denominar como la subplaca del tálamo, debido a la presencia de poblaciones celulares transitorias durante el desarrollo y a la expresión de genes compartidos con ésta (Montiel y col. 2011). 


\subsection{Conexiones tálamo-corticales y córtico-talámicas.}

Uno de los puntos claves en desarrollo del cerebro es la correcta formación de los circuitos y proyecciones que conectan diferentes estructuras cerebrales. En este punto resultan de gran importancia los circuitos que se establecen entre la corteza y el tálamo en desarrollo.

En los roedores, durante la segunda y tercera semana de desarrollo el prosencéfalo se divide en los diferentes prosómeros (esquema 3). Más o menos en esa época, la corteza y el tálamo comienzan a desarrollarse y a establecer conexiones entre ellos (en torno a E13 y E18 en el ratón). Sin embargo, a lo largo de su recorrido, las conexiones tálamo-corticales (TAC) y córtico-talámicas (CTA), han de atravesar diferentes divisiones anatómicas, que exhiben diferentes patrones moleculares. Éstas son las divisiones diencéfalo-telencéfalo y palio-subpalio (DDT y DPSP, respectivamente). Por ejemplo, la DPSP se caracteriza por la ausencia de expresión de los genes Amx1 y Dlx1 y la presencia de Pax6. En torno a E13,5, el tálamo dorsal comienza a emitir proyecciones que descienden a lo largo de la región ventral y posteriormente, se produce un giro brusco de $90^{\circ}$ en su trayectoria, para atravesar la DDT internándose en la cápsula interna $(\mathrm{Ci})$, en donde se produce una pausa en su avance (en torno a E15,5). Parece ser que las células de la Ci y proyecciones del NRT ayudan a las proyecciones talámicas en su camino al cortex (Molnár y col. 1998; Molnár y Cordery 1999).

Aproximadamente al mismo tiempo, desde la corteza empiezan a crecer axones de manera ventral hacia la DPSP, en donde se produce un cambio giro brusco en su trayectoria, deteniéndose igualmente en las inmediaciones de la Ci (en torno a E14,5 en la rata, Jacobs y col. 2007). Se ha descrito como las neuronas de la subplaca son las primeras en proyectar hacia la Ci y, posteriormente, unas pocas proyectan también hacia el tálamo (De Carlos y O'Leary 1992). Algunos autores han sugerido la posibilidad de que estas proyecciones de la subplaca ayudarían a las proyecciones CTA y TAC en el viaje a sus respectivas dianas, aunque no se ha conseguido demostrar aún (Molnár y col. 1998).

Tras su interacción, en las inmediaciones de la DPSP, las proyecciones TAC y CTA reanudan su avance, asociadas íntimamente. En este punto, algunos autores 
han propuesto una hipótesis denominada del "apretón de manos". Esta hipótesis postula que ambas proyecciones se encuentran y entremezclan en el telencéfalo basal y que, posteriormente las proyecciones continuan su viaje siguiendo el "andamiaje" marcado por sus predecesoras y, por tanto, el desarrollo de ambas se encontraría sincronizado (Molnár y Blakemore 1995). Aunque el contacto entre estas células ha sido ampliamente demostrado, no está claro si ambos tipos de proyecciones dependen unas de otras para llegar a sus destinos. En cuanto a los componentes moleculares, se sabe que el establecimiento de las conexiones talamo-corticales requiere de la expresión de Gbx2 en el tálamo y de Pax6 a lo largo del camino a recorrer. Pax6 es necesario para la correcta expresión de cadherinas y semaforinas. Así mismo, se sabe que el factor de transcripción Tbr1 es necesario para las proyecciones córtico-talámicas y tálamo-corticales. Por último, mutaciones en los genes Emx2, Mash1, Foxg1 y Pax6 impiden la correcta salida de las de las proyecciones talámicas del diencéfalo hacia el telencéfalo (López-Bendito $y$ col. 2006; Price y col. 2006). En ese sentido, el camino recorrido por las proyecciones viene marcado por diferentes moléculas guía y por la liberación de diferentes factores atrayentes y repulsivos. Aquí incluimos proteínas de la familia de las cadherinas (Cdh6, Cdh8 y Cdh11), las proteínas de membrana asociadas al sistema límbico (LAMP), la netrina, las efrinas, las semaforinas y las neurotrofinas (NT3). Así, se ha demostrado como el receptor de neurotrofinas $p 75$, se expresada por las células del subplaca y que su carencia impide la correcta formación de las conexiones TAC de la vía visual (McQuillen y col. 2002).

Asimismo, se ha descrito que un grupo especializado de células en la $\mathrm{Ci}$, denominadas "células de corredor", son necesarias para la correcta formación de las conexiones TAC. Estas células se originan en la EGL, desde donde migran tangencialmente hacia la EGM, en donde expresan isoformas de NGR-1 y de su receptor, permitiendo el paso de los axones TAC a través de un ambiente altamente quimiorrepelente (López-Bendito y col. 2006).

En cuanto al papel de la subplaca, se ha demostrado que la eliminación de la subplaca, antes de la llegada de las proyecciones tálamo-corticales, produce errores en el establecimiento de conexiones con la corteza (Ghosh y col. 1990). 
a)
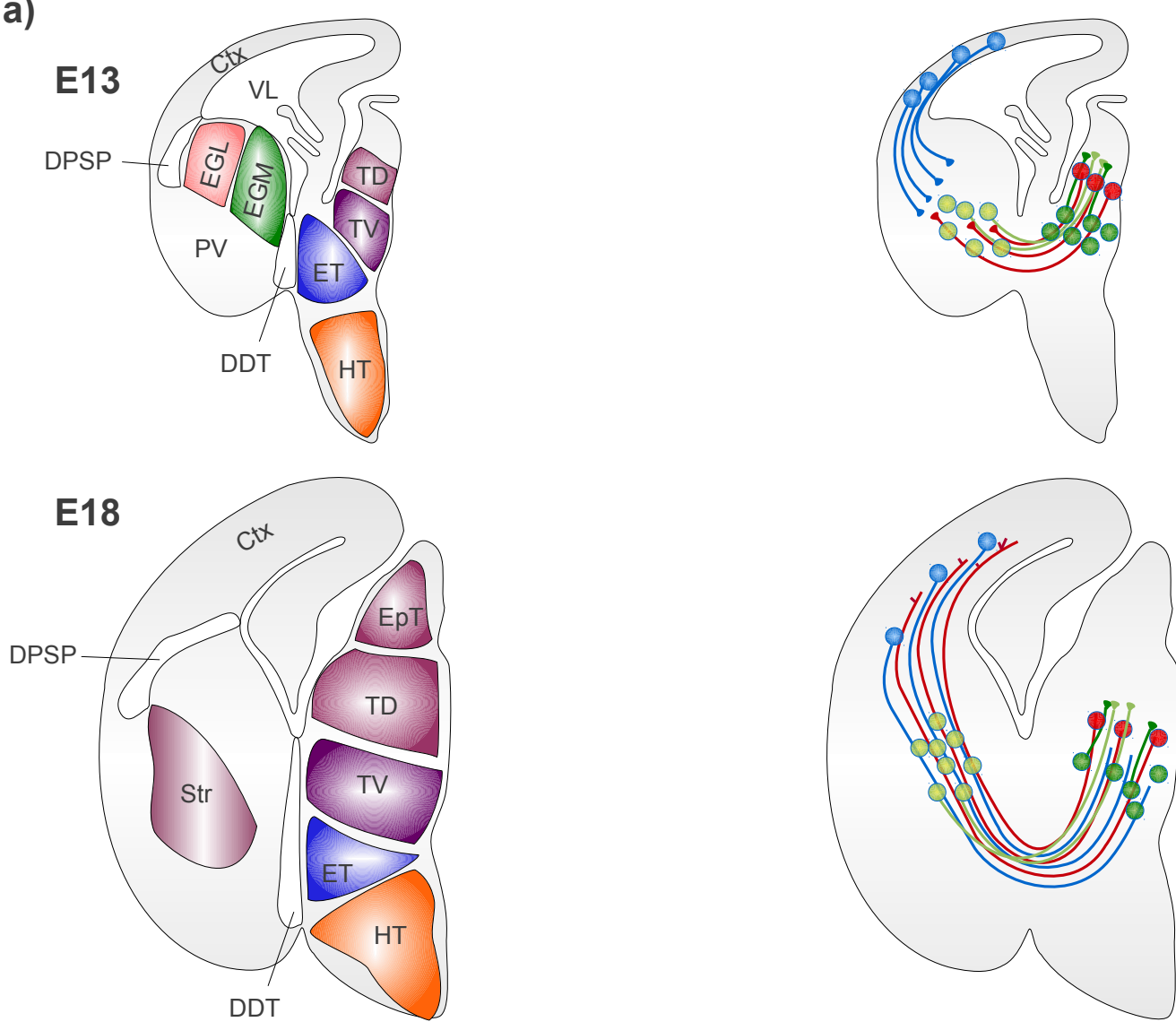

b)

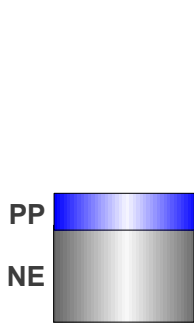

ZM

Pc

SP

ZI

ZSV

ZV

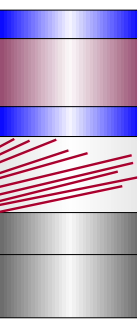

E15-E16

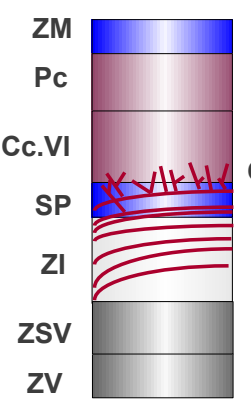

E18-E19

\begin{abstract}
ZM
Pc

Cc.V

Cc.VI

SP

ZI

ZSV

ZV
\end{abstract}

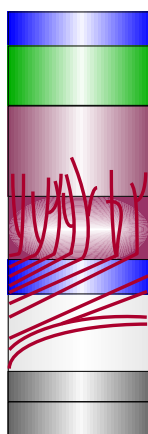

PO

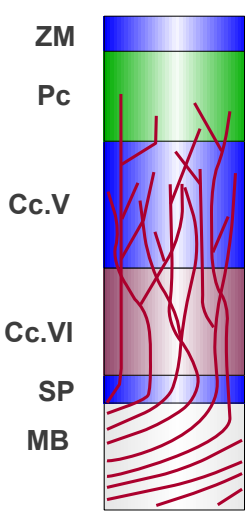

P2

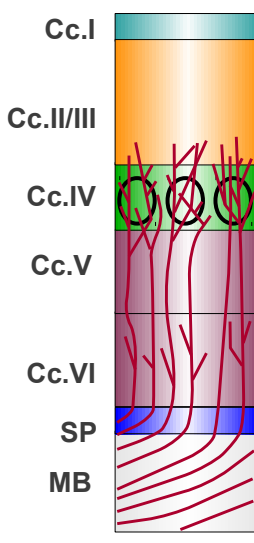

Adulto

Esquema 6- Establecimiento de las conexiones entre el tálamo y la corteza a lo largo del desarrollo. a) Durante el desarrollo, las proyecciones TAC (lineas rojas) y CTA (líneas azules) tienen que atravesar diferentes divisiones anatómicas, como la división palio-subpalio (DPSP) y la división diencéfalo-telencéfalo (DDT). Ambas proyecciones se desarrollan de manera sincronizada y se encuentran en las inmediaciones del palio ventral (PV). Parece que las células del NRT y la Ci (círculos verde oscuro y verde claro respecticamente) colaboran en el crecimiento y guía de los axones talámicos. Abreviaturas: Ctx, cortex; EGL, eminencia ganglionar lateral; EGM, eminencia ganglionar media; Str, estriado; HT, hipotálamo; ET, eminencia talámica; TV, tálamo ventral; TD, tálamo dorsal; EpT, epitálamo. b) Desarrollo de la corteza y crecimiento de las proyecciones talámicas. Cuando los axones talámicos llegan a la corteza (en torno a E15), se colocan por debajo de la densa placa cortical (Pc) en la subplaca (SP). Los axones invaden la corteza días antes del parto y crecen hasta su diana final en la capa IV, en donde adquieren su distribución característica en barril. Esquemas modificados de Lopez-Bendito y Molnár (López-Bendito y Molnár 2003). 
Además se ha descrito la presencia de una molécula quimiorrepelente en el hipotálamo, la cual impediría la entrada de los axones TAC en esta estructura (López-Bendito y Molnár 2003).

En los mamíferos, las conexiones TAC llegan a sus destinos en las regiones corticales antes de que las neuronas con las que contactarán hayan nacido, por lo que los axones tienen que esperar entre dos y tres días (entre E16 y E19 en los roedores) antes de penetrar la densa placa cortical. Parece ser que los axones se acumulan en la subplaca, interaccionando con sus células y reordenándose antes de invadir la placa cortical (Molnár y col. 1998; Price y col. 2006). Los axones talámicos desarrollan numerosos axones colaterales a medida que se acumulan en la subplaca. Asimismo, estos axones son capaces de producir despolarizaciones en la región de la subplaca durante esta época. Como hemos comentado, la actividad eléctrica es clave para la correcta formación de estas conexiones y la posterior formación de los clásicos barriles formados por estos axones en la placa cortical (Ghosh y col. 1990; Catalano y Shatz 1998). Parece ser que la subplaca actuaría como un centro integrador de señales durante el desarrollo, estableciendo sinapsis con las proyecciones TAC, por un lado y con las neuronas de la placa cortical en formación, por otro. Además, se ha descrito que las neuronas de la subplaca son capaces de establecer sinapsis eléctricas entre ellas, a través de "tight junctions", lo cual permitiría la propagación de señales a lo largo de todo el eje dorso-ventral y el refinamiento de las proyecciones que formarán las futuras columnas corticales (para una revisión ver Kanold y Luhmann 2010).

Justo antes del parto, los axones talámicos se ramifican y crecen desde la subplaca, invadiendo la placa cortical (en la rata este proceso ocurre entre E19 y E20, Molnár y Cordery 1999). Posteriormente estos axones establecen conexiones con la capa cortical correspondiente, que principalmente suele ser la capa IV en las conexiones sensoriales, aunque también el tálamo realiza conexiones con las capas I y V (Galazo y col. 2008) (ver esquemas 6 y 7).Por otro lado, los axones corticales viajan desde la Ci hacia el tálamo, deteniéndose durante dos días (en torno a E16,5 y E17,5 en la rata) en el tálamo ventral, en el núcleo reticular talámico (NRT), para posteriormente llegar a su destino en el tálamo dorsal (Molnár y Cordery 1999; Jacobs y col. 2007). 

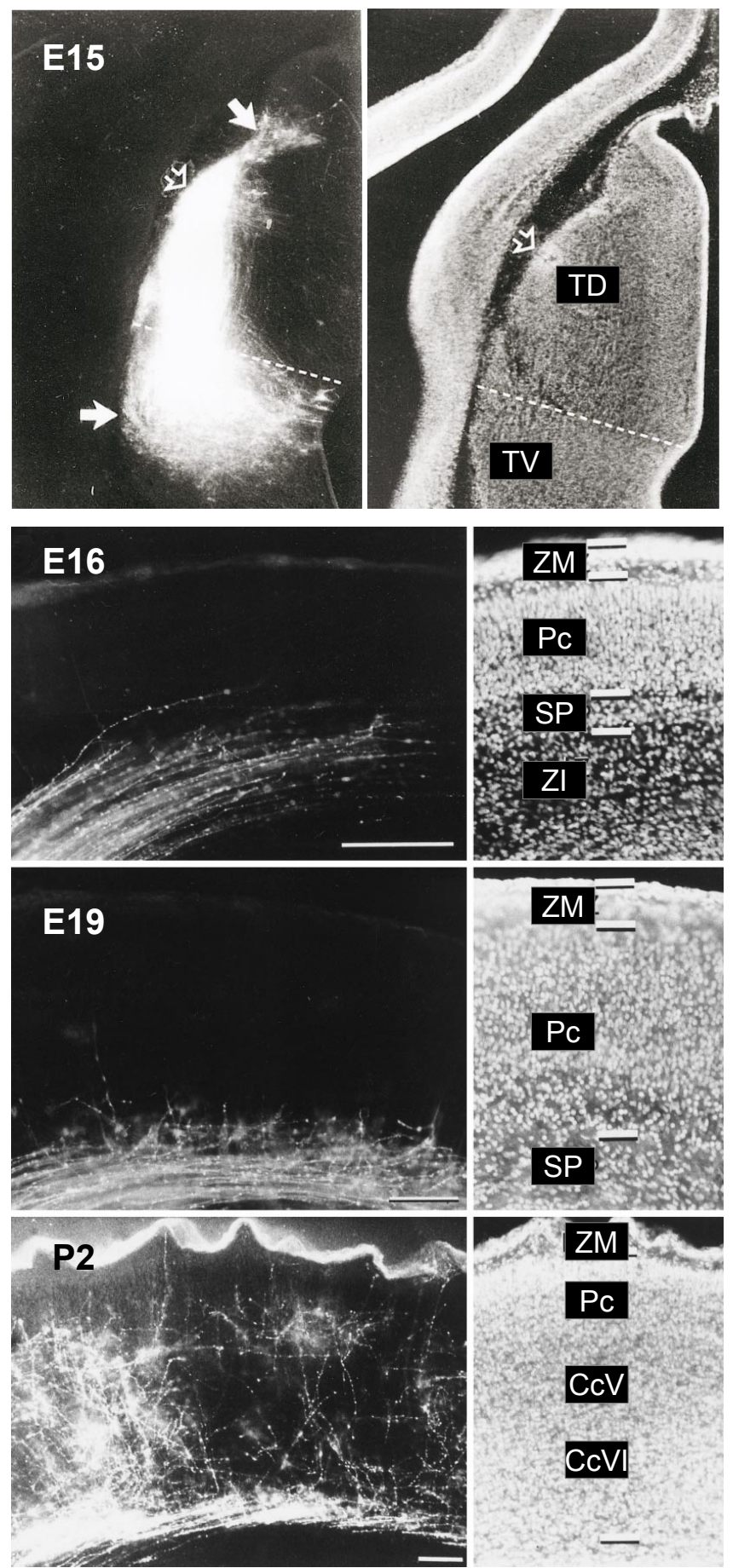

Esquema 7.- Establecimiento de las conexiones entre el tálamo y la corteza a lo largo del desarrollo. Fotografías de cuatro estadíos diferentes del desarrollo de las conexiones TAC, desde el tálamo hacia su destino en el hemisferio izquierdo, seguidas mediante la colocación de un cristal del trazador Dil en el tálamo dorsal (TD, flecha hueca). Las fotografías de la izquierda muestran los axones marcados por el trazador Dil y en la izquierda se muestra la contratinción de las mismas secciones teñidas con bisbenzimida. En E15 pueden observarse, principalmente, axones marcados con el trazador (flechas blancas) acumulándose en el tálamo ventral (TV) y, en menor medida, en el tálamo más dorsal. Más adelante en el desarrollo, en E16, las conexiones TAC comienzan a llegar a los hemisferios cerebrales, viajando por la zona intermedia (ZI) y la subplaca (SP). Estos axones no llegan a atravesar la placa cortical (Pc) y así, en E17 vemos una acumulación de estos axones en la SP. Además estos axones emiten ramificaciones desde su posición en la SP hacia la Pc, pero sin llegar a internarse en ella. De esa manera, el desarrollo del cerebro continúa y más axones llegan desde el tálamo a las regiones de la SP adyacentes a la placa cortical, en donde estableceran sus conexiones. Tras el parto, comienza desde la SP una invasión masiva de la Pc de proyecciones axonales de las conexiones TAC. Estas proyecciones atraviesan las capas corticales VI y V (CcVI y CcVI) hacia su destino en la capa cortical IV, aunque algunas de ellas pueden llegar incluso a la zona marginal (ZM). Fotografías extraídas y modificadas de Molnár (Molnár y col. 1998).

Para una revisión más extensa de la formación de las conexiones entre el tálamo y la corteza ver López-Bendito y Molnár 2003. 


\subsubsection{Migración celular}

En el prosencéfalo existen dos tipos principales de migración, en función de su orientación: la migración radial, en la que las células migran desde las zonas progenitoras hasta la superficie del cerebro, siguiendo la disposición radial de tubo neural; y la migración tangencial, en que las células migran de manera perpendicular respecto de la dirección de la migración radial (Marín y Rubenstein 2003).

\subsubsection{Migración radial}

Las neuronas de proyección de la corteza cerebral se originan en la zona ventricular (ZV) y en la zona subventricular (ZSV) de la región dorsal del encéfalo (palio) y migran radialmente a través de la zona intermedia de la corteza hasta alcanzar su posición definitiva en la placa cortical (Bayer y Altman 1991; Nadarajah y col. 2001; Gupta y col. 2002). La migración radial depende en gran medida de la interacción de las neuronas en migración con las prolongaciones de la glía radial (Mission y col. 1991), si bien durante las primeras fases del desarrollo cortical la migración radial parece ser independiente de la glía radial (Gupta y col. 2002; Nadarajah y Parnavelas 2002). Así, durante la formación de la preplaca (PP), al principio de la neurogénesis, las neuronas migran por translocación del soma. Sin embargo, en estadíos más avanzados del desarrollo las neuronas migran por locomoción celular, empleando como soporte a las células de la glía radial.

\subsubsection{Migración tangencial}

La migración radial no es el único modo de desplazamiento celular en la corteza cerebral, ya que la existencia de interneuronas orientadas de forma tangencial en la zona intermedia de la corteza en desarrollo sugiere que no todas las células corticales se desplazan de esa forma. Así pues se ha demostrado que las interneuronas corticales proceden de la región ventral del telencéfalo, es decir, del subpalio. (De Carlos y col. 1996). Estudios más recientes han confirmado que el subpalio es el origen de las interneuronas que finalmente residen en todas las áreas corticales, incluidas la neocorteza, el hipocampo o la corteza piriforme (Pleasure y col. 2000; Wichterle y col. 2001). 


\section{a) Migración radial}

$\left.a_{1}\right)$ Translocación del soma

Superficie Pial

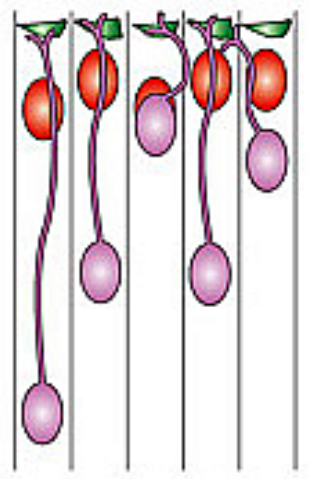

E13-E15 $a_{2}$ ) Locomoción

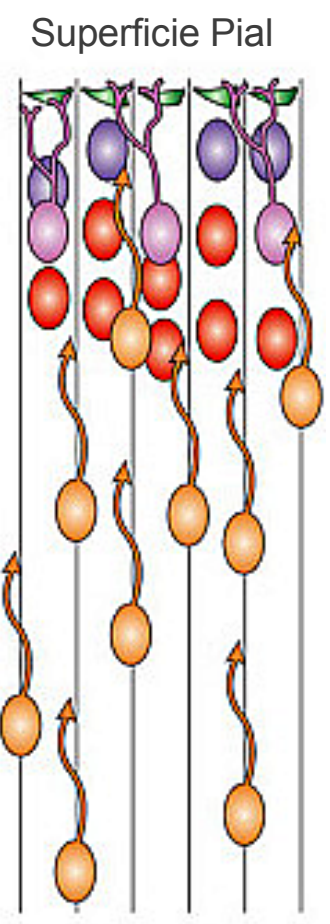

E15-E20

Esquema 8.- Tipos de migración de las neuronas de proyección y de las interneuronas de la corteza. a) Las neuronas de proyección llevan a cabo, durante el desarrollo de la placa cortical, dos tipos de migración radial: $a_{1}$ ) Translocación del soma. Este tipo de migración radial, es un movimiento continuo, mediante el cual el núcleo de las células se desplaza hacia el otro extremo, mediante el acortamiento del axón que se encuentra anclado en la superficie pial. Mediante este proceso se produce la formación de la preplaca y su posterior división en ZM y SP. $a_{2}$ ) A medida que aumenta el grosor de la placa cortical, las células no pueden extender procesos hasta el extremo de la superficie pial. De tal manera, utilizan la glía radial para el desplazamiento, manteniendo la longitud de sus esquemas. La translocación somal se sigue produciendo en los extremos superiores de la corteza. Esquema modificado de Gupta (Gupta y col. 2002). b) Principales rutas de migración de las interneuronas corticales durante el desarrollo embrionario. Abreviaturas: Hpc, hipocampo; EGL, eminencia ganglionar lateral; EGM, eminencia ganglionar medial; NCx, neocórtex; PCx, corteza pririforme; Str, estriado; ZSV, zona subventricular; ZV, zona ventricular. Esquema modificado de Marín y Rubenstein (Marin y Rubenstein 2001).

\subsubsection{Agregación celular}

Cuando las neuronas llegan a su localización definitiva tienden a agregarse formando las diferentes capas de la corteza cerebral o bien grupos nucleares. Algunas moléculas de naturaleza glicoproteica, y/o glicolipídica, intervienen en la formación de interacciones entre neuronas (Herschkowitz 1988).

Las interacciones de adhesión entre células se encuentran mediadas por dos 
grupos de componentes de unión, unos que necesitan calcio y otros que no. Así, encontramos dos grandes familias de moléculas transmembrana de adhesión, las cadherinas (dependientes de calcio) y las moléculas de adhesión similares a inmunoglobulinas (independientes de calcio) (Kandel y col. 2001). Las cadherinas son un grupo de unas 100 glicoproteínas, que presentan un extremo extracelular formado por cinco segmentos similares. Estas proteínas forman enlaces entre moléculas iguales (unión homofílica). Una de las principales cadherinas del sistema nervioso es la $\mathrm{N}$-cadherina. La superfamilia de las inmunoglobulinas, se trata de una familia aún mayor que la de las cadherinas, que se caracteriza por la presencia de uno a varios segmentos extracelulares ricos en puentes disulfuro. Las inmunoglobulinas realizan uniones homofílicas y heterofílicas. La inmunoglobulina mejor caracterizada es la molécula de adhesión celular neuronal (NCAM).

Empleando cultivos celulares se ha puesto de manifiesto que las superficies gliales pueden favorecer el proceso de agregación neuronal y que sustancias como la poli-L-lisina también favorecen dicha agregación (Vernadakis 1988). Además, la laminina, una glicoproteína presente en la matriz extracelular, parece ser una de las moléculas que favorece este proceso (Luckenbill 1997).

\subsubsection{Diferenciación neuronal}

La diferenciación neuronal se caracteriza por el crecimiento del cuerpo celular, la elaboración de axones y dendritas seguida de su crecimiento en longitud y grosor y por el agrupamiento de los cuerpos neuronales formando acumulaciones de las que parten radialmente las neuritas. Esta distribución da lugar a la disposición en materia blanca y materia gris que adoptan las neuronas en el SNC y a la adquisición de la propiedad de propagar potenciales de acción. En la rata, el proceso de diferenciación neuronal comienza durante la vida prenatal y se prolonga hasta la tercera semana de vida postnatal. En el hombre, la diferenciación neuronal empieza en el período prenatal y puede durar hasta los cuatro años (Meisami y Timiras 1982; Herschkowitz 1988).

En las neuronas, las dendritas y axones se originan en una estructura descrita por Ramón y Cajal (circa 1890) como conos de crecimiento (Herschkowitz 1988; 
Caviness 1989). Los conos de crecimiento guían a los axones, convirtiendo las señales positivas y negativas en órdenes que determinan el trayecto y la rapidez de crecimiento del axón. La sensibilidad del cono de crecimiento depende, en gran medida, de sus filopodios. Los filopodios son estructuras ricas en actina, muy móviles, que poseen receptores para moléculas que sirven como señales de dirección al axón (Sanes y Jessell 2001).

Es necesaria la presencia de un "sustrato permisivo" que permita el avance de los conos de crecimiento. Los conos de crecimiento reconocen diferencias entre los sustratos en los que crecen y esto puede regular la dirección y la velocidad de su crecimiento. Se han identificado numerosas sustancias capaces de favorecer el crecimiento in vitro de los axones, tales como el colágeno, la fibronectina y algunos proteoglicanos. Son de especial importancia las lamininas, componentes de todas las láminas basales de los seres vivos. Los conos de crecimiento poseen una serie de proteínas (integrinas) capaces de interaccionar con las lamininas de la matriz extracelular (Raper y Tessier-Lavigne 1999) y transmitir esta información al interior de la célula. Únicamente la unión con el sustrato permisivo no es suficiente para que se produzca el desarrollo de las neuronas inmaduras. Algunos neuropéptidos, como la somatostatina, la colecistoquinina, la sustancia $\mathrm{P}$ o el péptido intestinal vasoactivo, parecen estar estrechamente relacionados con los fenómenos de elongación axónica y de interconexión celular (Hayashi 1992). Por otro lado, el NGF (factor de crecimiento nervioso), neurotransmisores como la serotonina, la dopamina o la acetilcolina, así como la interacción con células gliales, también parecen estar implicados en este proceso (Hatten y Mason 1986; Vernadakis 1988; Ivins y Pittman 1989). Los axones de larga proyección tienden a crecer juntos en un fascículo común. La fasciculación de los axones está favorecida por la presencia de la molécula de adhesión NCAM (Caviness 1989).

Durante la diferenciación neuronal se activan los procesos de síntesis de RNA y de proteínas y aumenta la actividad de ciertas enzimas tales como la acetilcolinesterasa, la $\mathrm{Na}^{+} / \mathrm{K}^{+}$-ATPasa (bomba de sodio-potasio), la tirosina hidroxilasa, la GABA transaminasa, etc. Asimismo, aumenta la actividad de las enzimas de la glucolisis, del ciclo tricarboxílico y de la síntesis de lípidos (Meisami y Timiras 1982). 
El proceso de diferenciación neuronal está favorecido por la insulina y el IGF ("insulin-like growth factor"). La insulina estimula la síntesis de proteínas, aumenta ciertas actividades enzimáticas y favorece la producción de neuritas y la adquisición de la capacidad para la neurotransmisión (Baskin y col. 1987). Asimismo, se ha comprobado que algunos neurotransmisores, como el GABA y la serotonina, favorecen el crecimiento de las neuritas y el mantenimiento de las neuronas en cultivo (Spoerri 1988; Hamon y col. 1989; Lipton y Kater 1989; Michler 1990; Barbin y col. 1993). También el NGF ejerce efectos neurotróficos sobre las fibras adrenérgicas periféricas in vivo e in vitro (Levi-Montalcini 1982) y las colinérgicas del SNC (Houlgatte y col. 1989). Existen pruebas de que la somatostatina aumenta el crecimiento de las neuritas (Bulloch 1987; Grimm-Jorgensen 1987). Asimismo, se ha sugerido que el piruvato favorece el crecimiento de las neuronas del SNC en cultivo (Varon y col. 1987). También la presencia de astrocitos favorece el crecimiento de las neuronas (Seaton y col. 1988). En nuestro grupo se ha demostrado que los astrocitos sintetizan y liberan ácido oleico, un ácido graso que se comporta como un factor neurotrófico (Tabernero, Lavado, y col. 2001) (para una descripción más detallada ver la sección 1.3.1.3).

\subsubsection{Proteína asociada al crecimiento, GAP-43}

Durante los procesos de crecimiento neuronal, tanto durante el desarrollo neuronal como en procesos de regeneración, la expresión de GAP-43 (Growth Associated Protein 43, también denominada B-50, neuromodulina o F1) es máxima y se encuentra limitada al sistema nervioso, siendo así considerada marcadora de la diferenciación axonal (Skene 1989; Benowitz y Routtenberg 1997; Oestreicher y col. 1997) (ver esquema 9, más adelante). Esta proteína desaparece durante la vida adulta, quedando confinada en zonas cerebrales de alta plasticidad o en terminales sinápticos relacionados con la llamada potenciación a largo plazo (LTP), un proceso que se supone asociado a la memoria (Benowitz y Routtenberg 1997).

La GAP-43 se localiza fundamentalmente en los axones en crecimiento y, sobre todo, en los conos de crecimiento (ver esquema 9) uniéndose a la membrana mediante interacción con la F-actina, formando, así, la estructura interna de los axones (Skene y Virág 1989; Oestreicher y col. 1997). En el ratón, la GAP-43 al- 
canza su máxima expresión el día 4 de vida postnatal en el SNP y en las dos primeras semanas de vida postnatal en el SNC. A partir de este momento su expresión cae, aunque en ciertas poblaciones de neuronas, relacionadas con procesos de plasticidad neuronal, la GAP-43 puede ser detecta en estadíos posteriores (Benowitz y Routtenberg 1997; Oestreicher y col. 1997). En la rata se ha descrito que el momento de máxima expresión de la GAP-43 sucede durante la primera semana postnatal (Dani y col. 1991; Velasco y col. 2003).

La expresión del gen de la GAP-43 se encuentra muy restringida en las células neurales. La regulación de la actividad del promotor de la GAP-43 está mediada por una serie de factores de transcripción, miembros de la familia bHLH (basic Helix Loop Helix). Estos factores de transcripción se unen a la caja E1, localizada en el promotor P1 del gen de la GAP-43, y modulan positiva o negativamente la expresión del gen. Hasta el momento se han descrito seis factores de transcripción de esta familia, cuatro de ellos son represores de la transcripción (ME1a, E12, MES-1, MASH-1) y dos son activadores (NeuroD y NDRF) (Chiaramello y col. 1996; Ohtsuka y col. 1998). La expresión de la GAP-43 está también regulada a nivel del mRNA. Así, el NGF aumenta tres veces la vida media del mRNA de la GAP-43. Además, se ha propuesto que el aumento de la estabilidad del mRNA de la GAP-43 por el NGF está mediado por la activación de la proteína kinasa C (PKC) (Perrone-Bizzozero y col. 1993; Tabernero, Lavado, y col. 2001).

Una de las características estructurales más sorprendentes de la GAP-43 es su extrema hidrosolubilidad, hecho que no es habitual en una proteína asociada a membranas. Se sintetiza como proteína soluble y su asociación a la membrana probablemente está mediada por unión covalente de la región hidrofóbica del extremo amino-terminal a ácidos grasos. Esta región contiene un dominio activador de la proteína G. En la parte intermedia existe el denominado dominio IQ, compuesto por 12-15 aminoácidos, que constituye el sitio de unión a calmodulina. Además, en la parte intermedia existe un sitio de fosforilación para la proteína $G$, en la serina 41 que, a su vez, regula la unión de la GAP-43 a calmodulina. En el extremo carboxilo-terminal se localiza el motivo $F$, el cual interacciona con los componentes del citoesqueleto (Skene y Virág 1989). 


\subsubsection{Proteína asociada a microtúbulos, MAP-2}

Las proteínas MAP-2 se expresan en el sistema nervioso, siendo unas de las proteínas más abundantes en el cerebro (Olmsted 1986; Schoenfeld y Obar 1994). La MAP-2 tiene varias isoformas, que se forman a partir de un único gen por splicing alternativo del pre-mRNA (Maccioni y Cambiazo 1995). Dentro del sistema nervioso, las MAP-2 de alto peso molecular, MAP-2a y MAP-2b ( 300 kDa), se expresan específicamente en las dendritas de las neuronas (Schoenfeld y Obar 1994) y raramente en los axones, por lo que se pueden considerar proteínas marcadoras de la diferenciación dendrítica neuronal (Cáceres y col. 1984, 1986; Dinsmore y Solomon 1991)(ver esquema 9). Estas isoformas difieren en su patrón de expresión durante el desarrollo cerebral. En fases embrionarias y hasta el día 10 de vida postnatal, la única MAP-2 de alto peso molecular que se expresa en el cerebro es la MAP-2b. La MAP-2a aparece en etapas más tardías del desarrollo, expresándose mayoritariamente en el cerebro adulto.

Todas las MAP-2 tienen, en la región carboxilo terminal, un dominio de unión a la tubulina junto con una región rica en prolina. Se piensa que la región carboxiloterminal de la molécula de MAP-2 está fuertemente unida a los microtúbulos, mientras que el resto de la molécula se proyecta fuera de la superficie de los microtúbulos como brazo, por lo que se le denomina "dominio de proyección" (Sánchez y col. 2000). Además de asociarse a los microtúbulos para estabilizarlos y promover su ensamblaje, la MAP-2 ejerce un importante papel en el crecimiento de las neuritas (Woolf 1998). Otras funciones de la MAP-2 se resumen en su participación en la morfogénesis neuronal, en la dinámica del citoesqueleto, en el empaquetamiento de los microtúbulos y en el tráfico de orgánulos en los axones y las dendritas (Dinsmore y Solomon 1991).

Los patrones de expresión diferencial de las isoformas de MAP-2 y de cada uno de sus mRNAs durante el desarrollo del sistema nervioso, parecen indicar una compleja regulación de su expresión, tanto a nivel transcripcional o posttranscripcional como traduccional (Sánchez y col. 2000). Hasta el momento, los mecanismos de regulación post-traduccional de MAP-2 son mucho mejor conocidos que la regulación de la expresión de la proteína a otros niveles. 


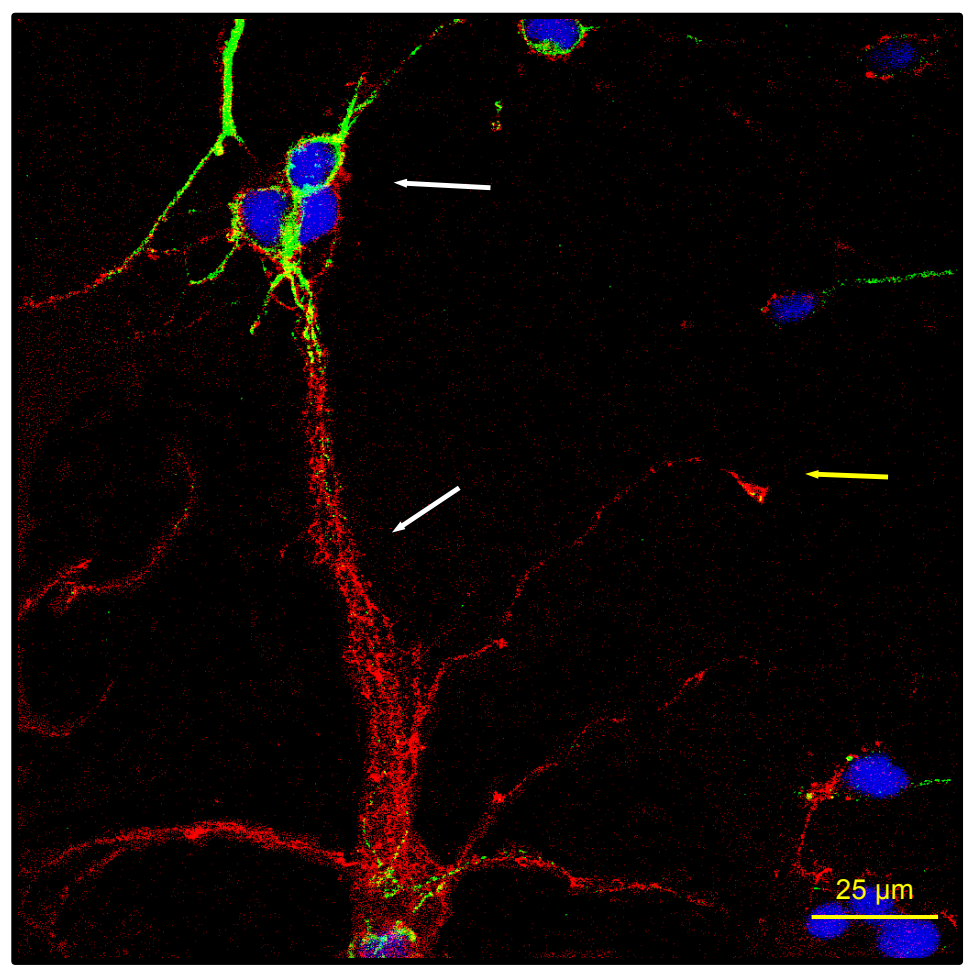

Esquema 9.- Localización inmunocitoquímica de las proteínas MAP-2 y GAP-43, en neuronas en cultivo primario. La imagen muestra una doble inmunohistoquímica confocal contra MAP-2 y GAP-43 en neuronas en cultivo primario. La MAP-2, marcadora del crecimiento dendrítico, aparece en verde y la GAP-43, marcadora del crecimiento axonal, aparece en color rojo (fechas blancas). En azul se marcan los núcleos teñidos mediante DAPI. La fecha amarilla señala un cono de crecimiento, el cuál se encuentra fuertemente marcado con la GAP-43. Esquema modificado de García-García y col. (no publicado).

Es este sentido, la MAP-2 es modificada post-traduccionalmente por fosforilación y desfosforilación en las neuronas durante el desarrollo, siendo provocada esta modificación por ciertas señales extracelulares (Avila y col. 1994). Estas modificaciones condicionan la capacidad de la MAP-2 para unirse a los microtúbulos y estabilizarlos. Se ha sugerido que la asociación de las MAPs con kinasas y fosfatasas puede ser esencial para su anclado al citoesqueleto, así como para su direccionamiento hacia compartimentos específicos neuronales, donde pueden desempeñar sus funciones específicas (Tsunoda y col. 1998). Es necesario un equilibrio kinasas/fosfatasas para el adecuado recambio y dinámica de los microtúbulos y, en consecuencia, para una función neural satisfactoria. Así una hiperfosforilación de las MAP-2 causa su liberación de los microtúbulos, provocando la retracción neurítica e, incluso, la muerte neuronal a largo plazo (Arias y col. 1998). Entre las diversas proteínas kinasas que pueden fosforilar la MAP-2 están la proteína kinasa $A(P K A)$, la proteína kinasa II dependiente de calcio/calmodulina (CAMKII), la PKC y las proteínas kinasas dirigidas por prolina. La desfosforilación 
de la MAP-2 se lleva a cabo por diversas serina-treonina fosfatasas, tales como las PP1, 2A, 2B (calcineurina) y 2C. Estas fosfatasas están muy concentradas en cerebro y se encuentran asociadas al citoesqueleto. Se cree que las fosfatasas juegan un papel esencial en la regulación de la plasticidad neuronal y en la transmisión sináptica (Sánchez y col. 2000).

\subsubsection{Sinaptogénesis}

Después de migrar y diferenciarse, las neuronas establecen sinapsis entre ellas. La mayoría de las sinapsis consisten en una región especializada en el saco axónico presináptico, una región receptora en una dendrita postsináptica y una estrecha hendidura entre ambas regiones (Kalil 1990). La sinaptogénesis es un proceso tardío de la diferenciación neuronal, si bien algunas sinapsis aparecen durante fases más tempranas (Caviness 1989).

Entre los diversos factores que pueden estimular la sinaptogénesis se encuentran neurotransmisores como la serotonina o el GABA. En este sentido, se ha observado que el GABA y la serotonina aumentan el desarrollo de neuropilos y de las sinapsis en neuronas en cultivo (Madtes y Redburn 1983; Hamon y col. 1989; Reisert y col. 1989). Asimismo, conviene señalar que, durante el establecimiento de las sinapsis se produce un incremento en el metabolismo oxidativo cerebral y aumenta la síntesis de fosfolípidos y de colesterol (Meisami y Timiras 1982; Bayer 1985). El colesterol juega, aparentemente, un papel clave en la sinaptogénesis. Durante este proceso, en el que se requieren elevadas cantidades de colesterol, su síntesis en las neuronas decrece (Poirier 1994). Sin embargo, las células de la glía sintetizan y aportan a las neuronas el colesterol necesario. La disponibilidad de colesterol parece ser el factor limitante para el desarrollo de las sinapsis maduras. Esto explica el retraso en la producción de sinapsis en el SNC en espera de la diferenciación de la glía, así como los efectos patológicos que se manifiestan por alteraciones en la homeostasis del colesterol o las lipoproteínas (Mauch y col. 2001).

Se cree que en las sinapsis existe, además, una importante transferencia bidireccional de sustancias esenciales para la supervivencia y el normal funciona- 
miento de las células presinápticas y postsinápticas como, por ejemplo, el NGF (Cowan 1987).

\subsubsection{Muerte neuronal durante el desarrollo}

La muerte neuronal por necrosis se produce como consecuencia de un trauma, de una isquemia o por acción de una sustancia tóxica. La muerte por apoptosis es una muerte programada por la propia célula, mediante un proceso activo que requiere la inducción de la maquinaria enzimática necesaria. Durante este último proceso las células disminuyen de tamaño, se produce una condensación de la cromatina, una fragmentación del DNA y, por último, sus restos celulares son fagocitados.

La muerte neuronal por apoptosis es frecuente durante el desarrollo del SNC, cuando se genera un gran número de neuronas de las que apenas la mitad van a sobrevivir. Esta pérdida tan elevada de neuronas es común a todos los vertebrados y parece ser un mecanismo de adaptación durante el desarrollo del sistema nervioso (Oppenheim 1991). En 1949 Hamburger y Levi-Montalcini propusieron la hipótesis del factor neurotrófico para explicar este fenómeno (Hamburger y LeviMontalcini 1949). Esta hipótesis propone que la supervivencia de las neuronas de proyección depende de una serie de factores neurotróficos secretados por las células diana a las que las neuronas van a inervar. Los factores neurotróficos se encuentran en una cantidad limitada y, por ello, sólo las neuronas que consiguen captarlos van a sobrevivir, y el resto morirán por apoptosis (Hamburger y LeviMontalcini 1949). Esta hipótesis se vio reforzada por el descubrimiento del NGF, factor regulador de la apoptosis (Cohen 1960).

Hoy en día, se considera a los fenómenos de apoptosis en el sistema nervioso como una parte fisiológica en su desarrollo, que regula el número de células, sus conexiones y la citoarquitectura final del sistema nervioso. Asimismo, se sabe que la supervivencia de las células nerviosas no depende únicamente de las señales de los factores neurotróficos clásicos, como NGF, sino que dependen también de diferentes factores de crecimiento pertenecientes a familias moleculares diversas (incluidos los neurotransmisores), así como de la actividad eléctrica de los axones 
vecinos (de la Rosa y de Pablo 2000).

Se ha descrito que la apoptosis ocurre en las células nerviosas en toda las etapas de su desarrollo. Así, durante las primeras etapas existe un balance entre proliferación y apoptosis, que es regulado por las proteínas del ciclo celular. De igual manera, durante la neurogénesis encontramos fenómenos de apoptosis a lo largo de todo el sistema nervioso (Boya y de la Rosa 2005). En el ratón, por ejemplo, encontramos entre E12 y E16 células apoptóticas a lo largo de toda la zona ventricular y la zona intermedia (Yeo y Gautier 2004).

\subsection{PROTEÍNAS PLASMÁTICAS Y LÍQUIDO CEFALORRAQUÍDEO EN EL DESARROLLO DEL ENCÉFALO}

Los fenómenos de desarrollo del cerebro durante la etapa embrionaria tienen lugar dentro de un micro-ambiente muy controlado y regulado. Ello viene determinado por el intercambio entre tres espacios principales: la sangre, el espacio ventricular, que se encuentra relleno por el líquido cefalorraquídeo (LCR) y el espacio intersticial de las propias células nerviosas. La composición de estos fluidos tiene un fuerte impacto sobre el desarrollo y el intercambio de sustancias entre ellos viene determinada por la existencia de una serie de barreras, generalmente denominadas como "barreras cerebrales" (ver esquema 10), en las que se incluyen la unidad neuro-vascular o barrera hematoencefalica (BHE), la barrera aracnoidea (meninges) y la barrera LCR-sangre existente en el plexo coroideo.

Estas barreras limitan la difusión pasiva de sustancias hidrosolubles, contribuyendo así a la homeostasis del cerebro, que junto a los mecanismos de transporte, permiten la entrada regulada de nutrientes y confieren al cerebro de un ambiente iónico óptimo para su funcionamiento (Davson y Segal 1996; Saunders y col. 2000). 
a) Unidad neurovascular: (barrera hematoencefálica)

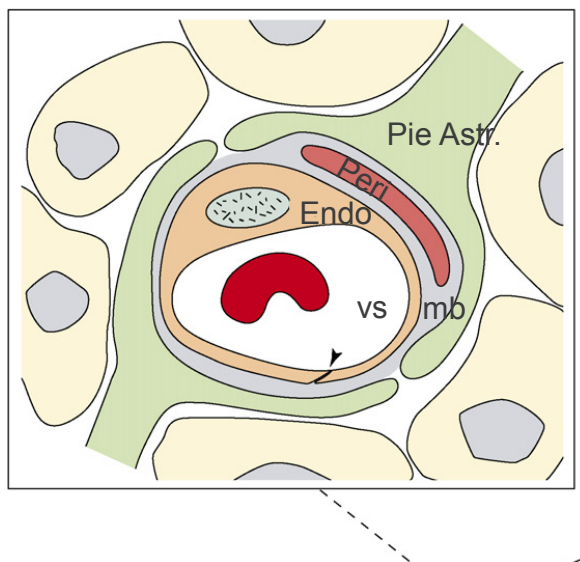

c) Meninges

(barrera aracnoidea)

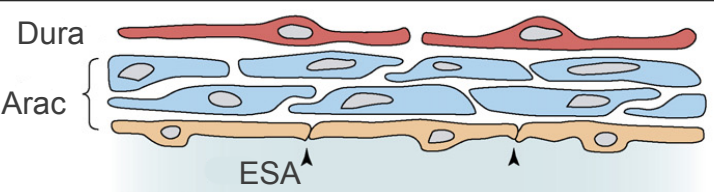

Pia

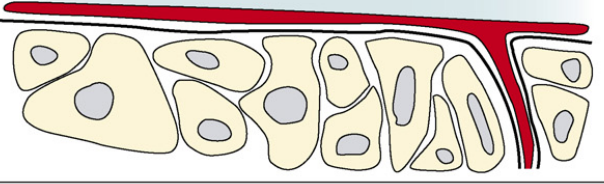

e) Neuroepitelio embrionario (barrera LCR-cerebro)

b) Plexo coroideo

(barrera sangre-LCR))
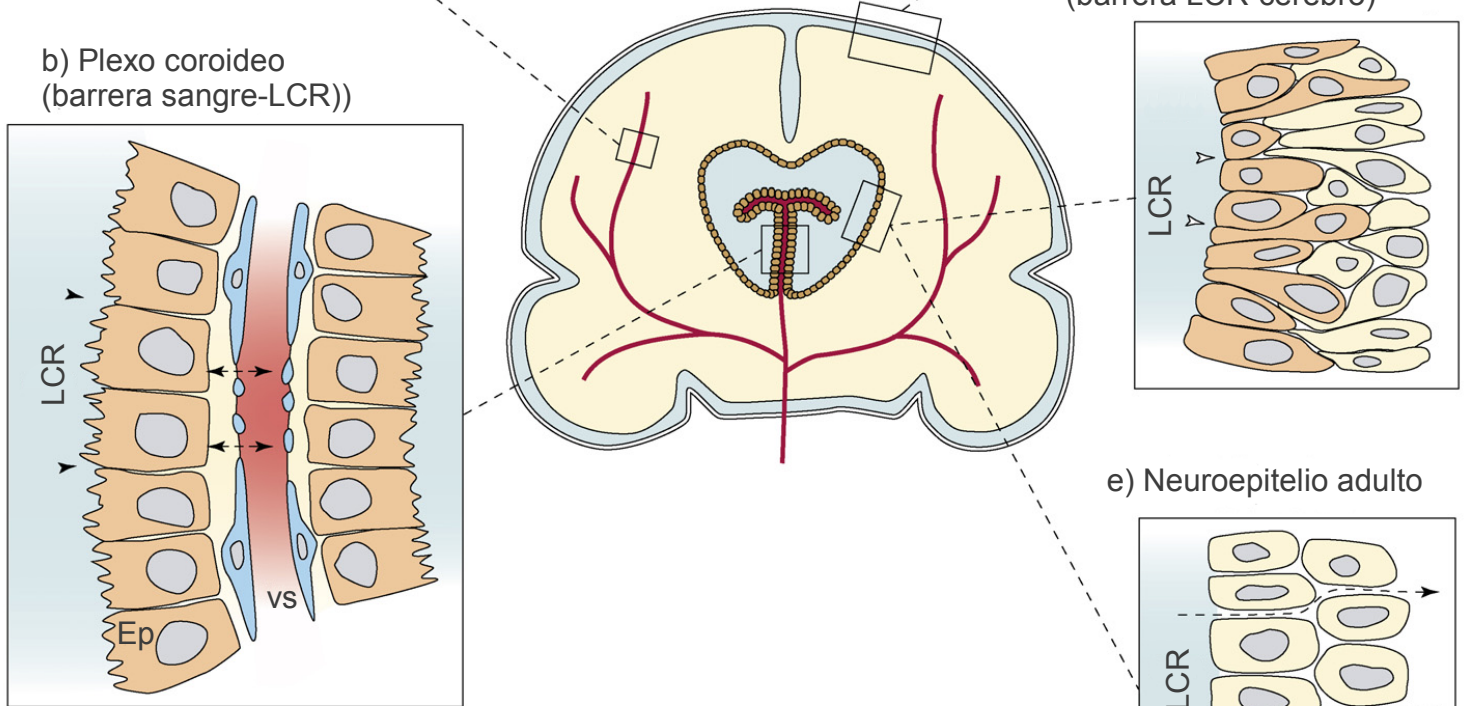

e) Neuroepitelio adulto

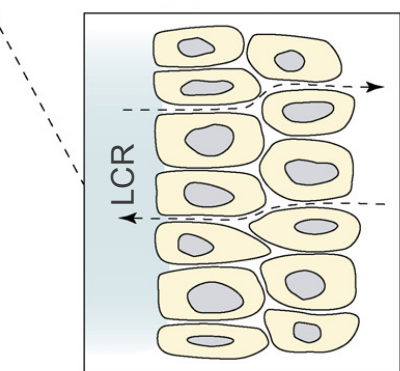

Esquema 10.- Representación esquemática de las barreras del cerebro (en naranja). a) La BHE representa la barrera entre el lumen de los vasos sanguíneos (vs) y el parénquima cerebral. Las celulas endoteliales (Endo) se encuentran cerradas por tight-junctions (cabezas de flecha) y están sostenidas por la lámina basal y rodeadas por los pericitos (Peri) y los pies terminales de los astrocitos (Pie Astr.). b) La barrera LCR-sangre es la barrera que existe entre los vasos sanguíneos del plexo coroideo y el LCR. Los vasos sanguíneos del plexo coroideo están fenestrados (flechas), permitiendo el intercambio de sustancias. Sin embargo, las células epiteliales (Ep) del plexo, están unidas por tight-junctions (cabezas de flecha), limitando el intercambio con el LCR. c) La barrera aracnoidea es menos conocida, pero en ella encontramos igualmente que las células aracnoideas se encuentran unidas por "tight-junctions" y separan el espacio subaracnoideo (ESA) del resto de estructuras adyacentes. d) La barrera cerebro-LCR sólo se encuentra presente durante el desarrollo fetal. Las células neuroepiteliales se encuentran unidas por strap-junctions, que impiden el paso de moléculas grandes como proteínas. d) Durante la vida adulta se pierden esas uniones y no existe restricción entre el LCR y el parénquima. Modificado de (Saunders y col. 2008). 
La principal característica anatómica de estas barreras es la presencia de uniones estrechas o "tight-junctions" entre las células. Así, vemos que la BHE se encuentra formada por una monocapa de células endoteliales, conectadas por uniones estrechas y sostenidas por la lámina basal; ésta última está rodeada por pericitos, células de la musculatura lisa y los pies terminales de astrocitos (esquema 10a). En el plexo coroideo, los capilares sanguíneos se encuentran fenestrados, aunque están rodeados por células epiteliales del plexo, las cuales se encuentran unidas por uniones estrechas, lo cual limita el intercambio de moléculas entre la sangre y el LCR (esquema 10b). Adicionalmente, durante la etapa embrionara ha sido descrita la presencia de una barrera a nivel de las células neuroepiteliales que rodean los ventrículos y que limita el intercambio de sustancias entre el LCR y el parénquima cerebral, permitiendo el paso de moléculas pequeñas, como la sacarosa, pero impidiendo el paso de grandes proteínas por difusión (Johansson y col. 2008). Esta barrera no existe durante la etapa adulta y se encuentra formada por un tipo especializado de uniones estrechas, denominadas uniones en correa o "strap-junctions" (esquemas 10d y 10e). En la rata se han descrito uniones similares que son funcionales desde E14 (Johansson y col. 2008).

De manera clásica se había asumido que estas barreras se encontraban en un estadío inmaduro y menos funcional durante el desarrollo, debido a una mayor permeabilidad a moléculas pequeñas. Esta hipótesis se basaba en el hecho de que durante el desarrollo la concentración de proteínas en el líquido cefalorraquídeo de numerosas especies es mucho mayor que en el adulto, al contrario de lo que ocurre con la concentración de proteínas en el plasma, que es mayor durante la vida adulta. (Dziegielewska y col. 2000; Johansson y col. 2008). En todas esas especies, la concentración de proteínas en el LCR aumenta al comienzo del desarrollo, alcanzando un pico máximo para disminuir después hasta la vida adulta. La permeabilidad sigue el mismo patrón durante el desarrollo. Estos datos se interpretaron como un cierre paulatino de las barreras inmaduras. Sin embargo, las tight-junctions se encuentran presentes en las barreras del cerebro muy tempranamente (E13 en el ratón) y son perfectamente funcionales (Ek y col. 2011).

El cerebro y la médula espinal, se encuentran rodeados, interna y externamente, por el líquido cefalorraquídeo (LCR), el cuál es secretado por las células epite- 
liales del plexo coroideo, localizado en cada uno de los 4 ventrículos. La presencia de la mayoría de las proteínas en el LCR tienen su origen en el plasma, desde el que son transportadas a través de células especializadas del plexo coroideo. Este transporte es específico, impidiendo el paso, por ejemplo, de albúminas modificadas químicamente o la de otras especies (Johansson y col. 2006, 2008; Saunders y col. 2011). En la rata ese mecanismo se encuentra presente muy tempranamente (E15), habiéndose descrito la existencia de células del plexo especializadas en el transporte de proteínas concretas (Liddelow y col. 2010, 2011).

La importancia del LCR en el desarrollo del cerebro, se encuentra ampliamente descrita en la bibliografía, tanto por su composición (Mashayekhi y col. 2002; Owen-Lynch y col. 2003; Miyan y col. 2006; Johansson y col. 2010; Lehtinen y col. 2011) como por la presión ejercida por el mismo (Gato y Desmond 2009). Como hemos comentado anteriormente, durante el desarrollo se produce un incremento de las proteínas plasmáticas presentes en el LCR, el cual es debido a un mecanismo de transporte activo desde el plasma hacia el LCR (Dziegielewska y col. 2000; Johansson y col. 2006). Numerosos autores han señalado la relación entre este aumento de la concentración de proteínas en el LCR y el desarrollo del sistema nervioso (Dziegielewska y col. 2000; Medina y Tabernero 2010).

Sin embargo, el acceso de esas proteínas al parénquima cerebral está restringido por la existencia de la barrera formada por las células neuroepiteliales, de manera que no se observa presencia de proteínas plasmáticas en el espacio extracelular del cerebro. No obstante, existen evidencias de células nerviosas marcadas para diferentes proteínas plasmáticas, como la fetuína, la transferrina, la alfa-fetoproteína (AFP) y la albúmina (Attardi y Ruoslahti 1976; Toran-Allerand 1980, 1982; Martínez-Cerdeño y col. 2006; Johansson y col. 2008). Además, se ha demostrado la capacidad de las células nerviosas de captar proteínas plasmáticas (Uriel y col. 1981; Cavanagh y Warren 1985; Tabernero, Lavado, y col. 2001).

Es por ello que decidimos estudiar en mayor profundidad, las dos principales proteínas plasmáticas presentes en el cerebro únicamente durante el desarrollo: la albúmina y la AFP (Dziegielewska, Evans, Lai, y col. 1981). 
Humano

E 49

E 54
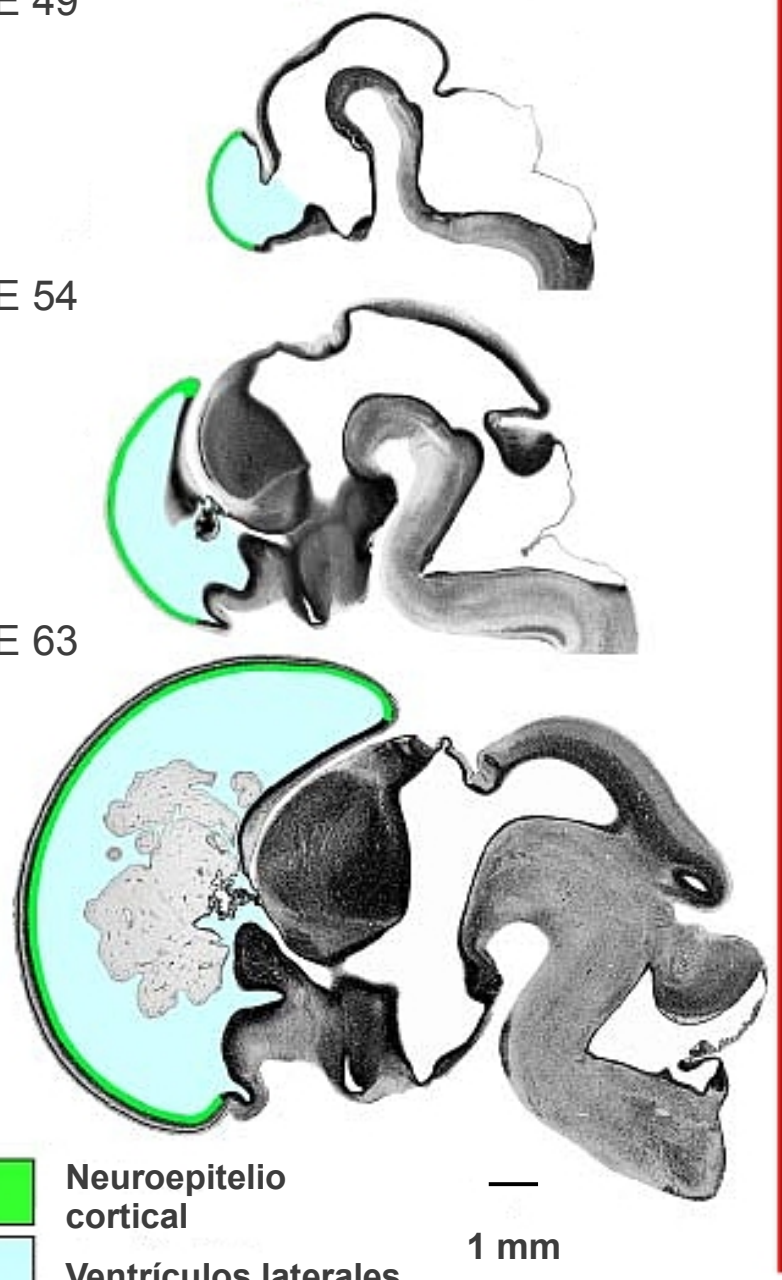

Rata

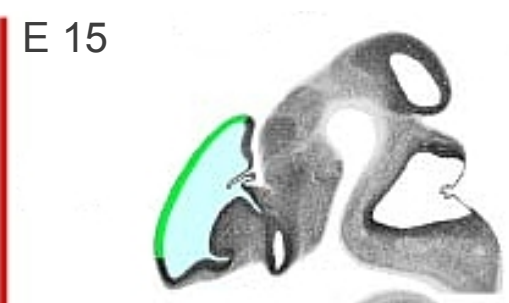

E 16
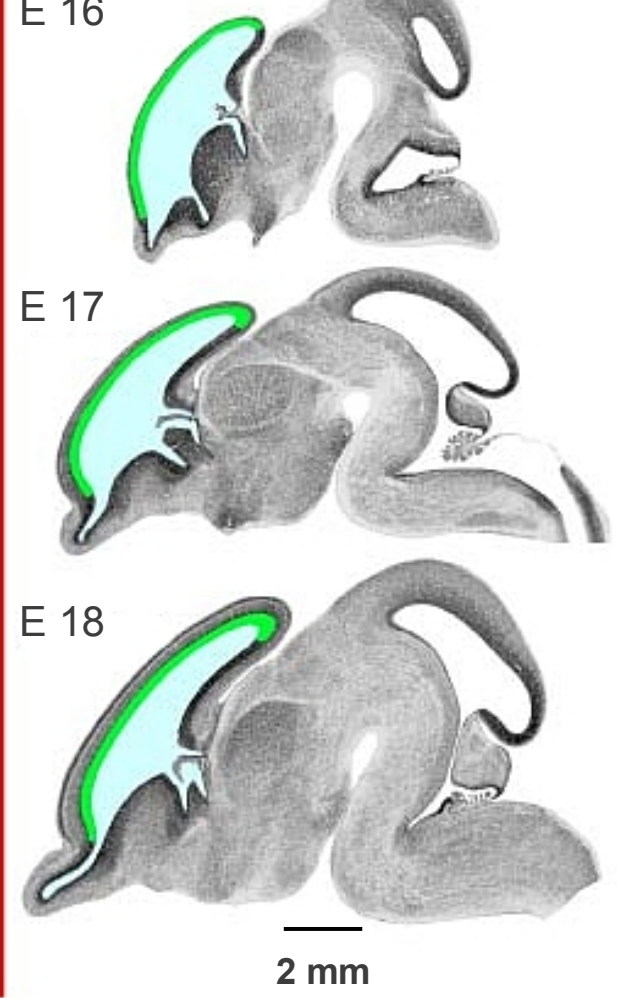

Esquema 11.- Comparación del desarrollo del cerebro en el ser humano y en la rata en etapas equivalentes del crecimiento embrionario. Es importante destacar el mayor tamaño de la "cúpula" cortical en el cerebro humano, que cubre el gran ventrículo lateral el cual encierra al plexo coroideo, mucho más desarrollado en el ser humano. Figura extraída de neuronvelopment.org (Altman y Bayer 2012).

\subsubsection{La albúmina}

La albúmina es la proteína plasmática más importante, desde el punto de vista cuantitativo, pues representa cerca del $60 \%$ de las proteínas plasmáticas. La albúmina es sintetizada en el hígado como pre-proalbúmina. Posteriormente, el precursor sufre dos cortes consecutivos, en el retículo endoplasmático y en el aparato de Golgi, respectivamente, obteniéndose la forma madura de la albúmina. Es secretada por hígado y tiene una vida media en el plasma sanguíneo de aproximadamente 20 días. 


\subsubsection{Estructura y principales funciones de la albúmina}

La albúmina pertenece, junto a la alfa-fetoproteína (AFP), la proteína transportadora de vitamina D y la alfa-albúmina (afamina), a la misma familia proteica, denominada familia albuminoide. Esta familia se caracteriza por poseer una estructura terciaria en forma de corazón, compuesta por tres dominios hómologos (designados como dominios I, II y III) (Mizejewski 2001). Los dominios están constituidos, cada uno, por subdominios enfrentados, formados por a-hélices continuas en paralelo, estabilizadas por puentes disulfuro. (He y Carter 1992). Los genes de estas cuatro proteínas se disponen en tándem dentro del mismo cromosoma (cromosoma 4 en humanos y cromosoma 14 en la rata) (Nahon 1987; Bélanger y col. 1994; Kajiyama y col. 2006). Se cree que estos genes se generaron a partir de sucesivos procesos de duplicación de un gen ancestral común, ya que presentan una estructura similar formada por 15 exones y 14 intrones (Nahon 1987; Nishio y Dugaiczyk 1996). La regulación de la expresión de estos genes se produce a nivel transcripcional (Nahon 1987).

La albúmina humana consiste en una cadena simple de 585 aminoácidos, con una masa molecular de 66,438 kDa, que carece de residuos glicosilados. Esta proteína tiene una estructura muy resistente y recupera con facilidad su conformación original, principalmente debido a los puentes disulfuro que le proporcionan la rigidez necesaria, especialmente en condiciones fisiológicas. La desnaturalización de esta proteína sólo ocurrirá en condiciones extremas y no fisiológicas, tales como cambios drásticos de $\mathrm{pH}$, temperatura o cambios en el medio, como agentes químicos o iones, siendo esta desnaturalización reversible.

La función principal de la albúmina es la unión y transporte de ligandos, tanto endógenos como exógenos, los cuales pueden unirse tanto de manera covalente, como no covalente. La gran capacidad de esta proteína para unir ligandos se debe, en gran parte a su gran flexibilidad, pudiendo cambiar su conformación fácilmente.

La albúmina humana posee siete sitios de unión a ácidos grasos de cadena larga, tres de los cuales con elevada afinidad para el ácido oleico, y once sitios de unión para ácidos grasos de cadena media (Bhattacharya y col. 2000). La unión 
de los ácidos grasos a la albúmina se produce por interacción hidrofóbica y enlace electrostático entre el anión carboxilo y un residuo cargado positivamente (Spector y Fletcher 1978). Esta unión depende de dos factores fundamentales: es directamente proporcional a la razón molar ácido graso-albúmina y depende de la estructura de la cadena hidrocarbonada del ácido graso. Así, para una misma razón molar ácido graso-albúmina, la fuerza de unión aumenta con la longitud de la cadena y para una misma longitud de la cadena hidrocarbonada, la inserción de un único doble enlace en cis aumenta la fuerza de unión. Sin embargo, la inserción de un segundo doble enlace reduce la fuerza de unión con respecto a su ácido graso saturado. En este sentido, el ácido graso con más afinidad por la albúmina es el ácido oleico (Curry y col. 1999).

La mayoría de los ácidos grasos captados por las células, formando complejo con la albúmina, se esterifican y se incorporan a la célula en forma de fosfolípidos, ésteres de colesterol, glicoesfingolípidos o bien se oxidan como fuente de energía. Las membranas plasmáticas mantienen aproximadamente una proporción 1:1 de ácidos grasos saturados e insaturados. Alteraciones en esta proporción producen cambios en la fluidez de la membrana, lo cual altera su funcionalidad (Gurr $y$ col. 2002).

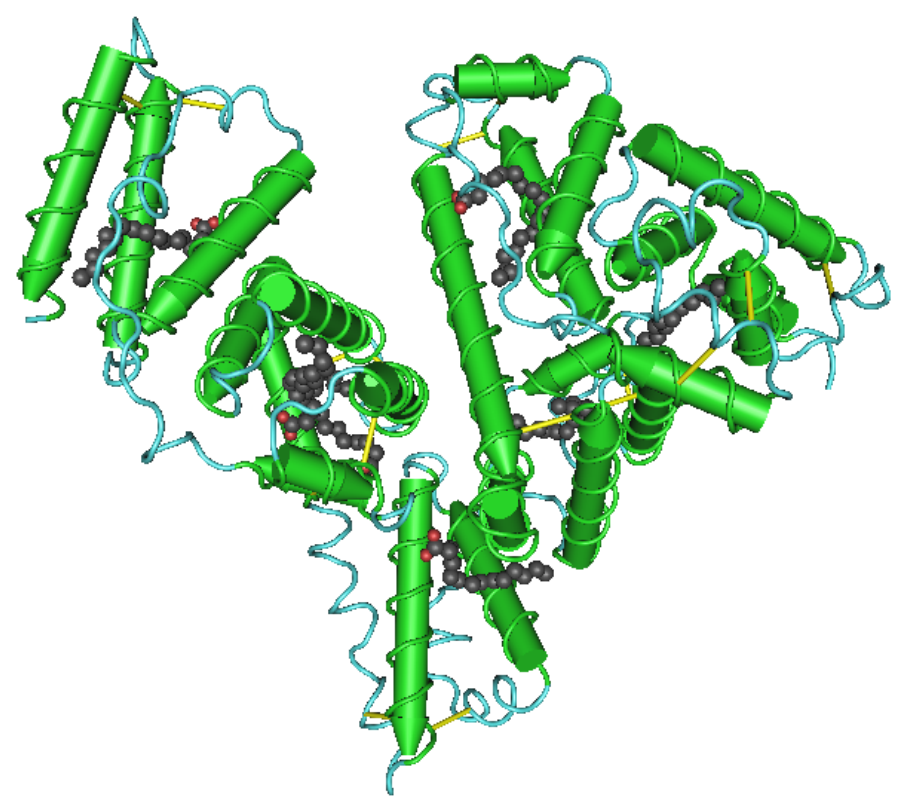

Esquema 12.- Estructura terciaria de la albúmina. Esquema tridimensional de la albúmina sérica humana con siete moléculas de ácido oleico unidas. 


\subsubsection{La albúmina en el cerebro}

El cerebro durante el desarrollo, al contrario que durante la vida adulta, capta específicamente albúmina sérica en los periodos prenatal y postnatal, coincidiendo con la etapa de máximo desarrollo. Se ha descrito la presencia de altas concentraciones de albúmina en el cerebro y en el líquido cefalorraquídeo en los días previos al nacimiento y durante los primeros días de vida postnatal (Trojan y Uriel 1979; Dziegielewska, Evans, Lai, y col. 1981; Møllgård y Jacobsen 1984; Velasco y col. 2003). Tanto las neuronas (Fishman y col. 1990; Granda y col. 2003) como los astrocitos en cultivo (Juurlink y Devon 1990; Tabernero y col. 1999) son capaces de captar albúmina de forma activa. Recientemente se ha descrito por nuestro grupo la presencia de albúmina en el plexo coroideo y en el parénquima cerebral durante el desarrollo postnatal, en ratas (Polo-Hernández y col. 2010).

La presencia de albúmina en el cerebro se debe a la existencia de un mecanismo según el cual la albúmina es transferida de la sangre al LCR y al cerebro. Este mecanismo es específico para la albúmina, puesto que modificaciones químicas de esta proteína impiden su transferencia al cerebro. Además, la albúmina de distintas especies es incapaz de alcanzar el LCR, indicando la existencia de un receptor específico para la albúmina en los capilares sanguíneos, que se expresa sólo durante el desarrollo cerebral (Habgood y col. 1992; Johansson y col. 2006).

Se ha descrito un papel importante de la albúmina en células cerebrales, como es la regulación de la proliferación astrocítica o el control de los niveles intracelulares de calcio (Nadal y col. 1995). También se ha observado que la albúmina, en ausencia de factores neurotróficos exógenos, es capaz de inhibir in vitro la muerte neuronal por apoptosis, en un proceso mediado por el glutamato, permitiendo a las neuronas en cultivo mantener su programa de diferenciación (Tabernero, Granda, y col. 2002). Además, se ha descrito que la albúmina regula el metabolismo de células cerebrales (Vicario y Medina 1992; Tildon 1993). Una de las primeras observaciones relacionadas con el efecto de la albúmina en el desarrollo cerebral fue el efecto drástico que esta proteína muestra en la utilización del lactato por los astrocitos (Vicario y col. 1993). En este sentido, se observó que, en cultivos primarios de astrocitos, la albúmina aumenta significativamente la utilización 
de glucosa y lactato mediante la activación de la piruvato deshidrogenasa (PDH) (Tabernero y col. 1999). Este efecto es específico y dosis-dependiente de albúmina (alcanza un máximo a concentraciones del $1 \%(\mathrm{p} / \mathrm{v})$ ) y no es mimetizado por otras proteínas, como las gamma-globulinas, o por compuestos de masa molecular semejante, como el dextrano. Sin embargo, sólo aumenta discretamente otras vías metabólicas, tales como el ciclo tricarboxílico o el ciclo de las pentosas fosfato, indicando que ejerce su efecto específicamente sobre la reacción catalizada por la PDH (Tabernero y col. 1999). Además, el aumento de la actividad de la PDH promovido por la albúmina es neutralizado por ácidos grasos, sugiriendo que la albúmina aumenta la actividad de la PDH por captación de ácidos grasos o de sus derivados acil-CoA (Tabernero y col. 1999).

\subsubsection{La albúmina y el factor neurotrófico ácido oleico}

Dado que la presencia de la albúmina en el cerebro se encuentra regulada en el desarrollo, se ha sugerido que esta proteína pudiera jugar un papel importante en la diferenciación neuronal. Se ha descrito que, en astrocitos, la albúmina aumenta específicamente la biosíntesis del factor neurotrófico ácido oleico, a partir de lactato, glucosa y 3-hidroxibutirato, de una forma dosis-dependiente (Tabernero, Lavado, y col. 2001). El ácido oleico, o cis-9-octadecenoico (18:1c $\Delta 9$ ), es un ácido graso formado por 18 átomos de carbono con una insaturación en posición cis en $\Delta 9$, introducida por una reacción de oxidación catalizada por la estearil-CoA 9-desaturasa-1 (SCD-1), la enzima limitante en la síntesis de los ácidos grasos monoinsaturados. La síntesis de ácido oleico promovida por la albúmina en astrocitos se detalla en el esquema 13.

La albúmina es endocitada en los astrocitos en un proceso mediado por el receptor megalina, y dependiente de caveolinas y de la proteína DAB-1 (Bento-Abreu y col. 2008, 2009). Una vez dentro del astrocito, la albúmina es translocada al aparato de Golgi y, posteriormente, al retículo endoplásmico. En el retículo, la albúmina capta el ácido oleico, induciendo de esta forma la activación del factor de transcripción SREBP-1, que promueve la expresión de la enzima estearil-CoA desaturasa-1 (SCD-1), enzima limitante de la síntesis de ácido oleico. Por último, el complejo albúmina-ácido oleico es liberado al espacio extracelular por exocito- 
sis activa. In vivo, la SCD-1 es expresada en la zona periventricular durante los primeros días de vida postnatal (Polo-Hernández y col. 2010).

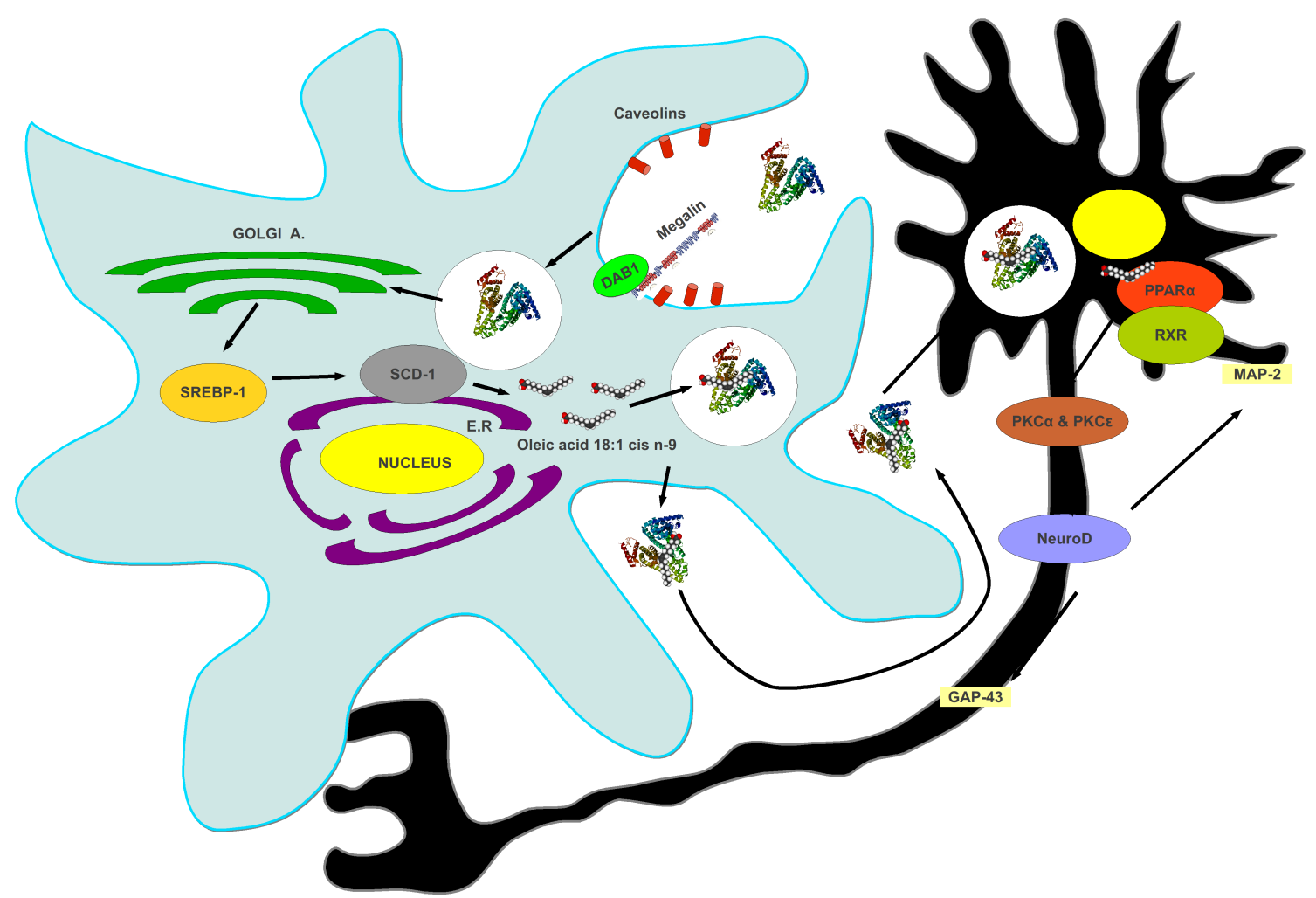

Esquema 13.- Mecanismo propuesto de síntesis del ácido oleico en astrocitos y de su efecto neurotrófico en neuronas. La albúmina es internalizada en los astrocitos por endocitosis mediada por receptor (megalina) y en un proceso dependiente de caveolinas y DAB-1. Una vez dentro del astrocito, se produce la transcitosis de la albúmina con paso por el aparato de Golgi y el retículo endoplásmico. En el retículo, la albúmina capta el ácido oleico, induciendo de esta forma la activación del factor de transcripción SREBP-1, que promueve la expresión de la enzima estearilCoA desaturasa-1 (SCD-1), enzima limitante de la síntesis de ácido oleico. Seguidamente el complejo albúmina-ácido oleico es liberado al espacio extracelular por exocitosis activa. Posteriormente el ácido oleico induce en neuronas su diferenciación, caracterizada por el aumento de la síntesis de las proteínas marcadoras MAP-2 y GAP-43 y promovida a través de PPARs y PKC.

El ácido oleico, sintetizado y liberado por los astrocitos en respuesta a la albúmina, actúa como factor neurotrófico, induciendo la diferenciación neuronal. Ésta se caracteriza morfológicamente por el agrupamiento neuronal seguido del crecimiento de las neuritas, que terminan diferenciándose en dendritas o axones y, molecularmente, por el aumento de la expresión de las proteínas marcadoras de diferenciación axonal, GAP-43, y dendrítica, MAP-2 (Tabernero, Lavado, y col. 2001; Rodríguez-Rodríguez y col. 2004). El efecto neurotrófico del ácido oleico se ha verificado in vitro, tanto en cultivos primarios de neuronas en presencia del complejo albúmina-ácido oleico, como en co-cultivos de astrocitos y neuronas en 
presencia de albúmina e, in vivo, en neonatos de rata (Tabernero, Lavado, y col. 2001; Polo-Hernández y col. 2010). La presencia de ácido oleico en el cultivo induce que las neuronas se dispongan siguiendo los patrones que se observan in vivo. En este sentido, se ha observado que los somas neuronales se agrupan formando estructuras que se asemejan a la materia gris y prolongan sus axones hasta contactar con las colonias de neuronas adyacentes, dejando un espacio equivalente a la materia blanca en el SNC (Tabernero, Lavado, y col. 2001). El efecto causado por el ácido oleico (18:1c $\Delta 9$ ) sobre la expresión de la MAP-2 y de la GAP-43 no se observa en presencia de otros ácidos grasos estructuralmente parecidos, tales como el ácido elaídico (18:1t $\Delta 9$ ), el cuál es la isoforma trans del ácido oleico, o el ácido palmítico (16:0), lo que demuestra la importancia del doble enlace en cis para que el efecto del ácido graso sea específico (Tabernero, Lavado, y col. 2001). In vivo, la albúmina induce la síntesis del ácido oleico en la ZSV, el cuál induce el aumento de la expresión de GAP-43 y de la fasciculación de los axones de las neuronas del núcleo estriado (Polo-Hernández y col. 2010).

Además, el ácido oleico se incorpora en los fosfolípidos de la membrana neuronal en forma de fosfatidilcolina y fosfatidiletanolamina. Esta incorporación es dependiente de albúmina, lo que sugiere que la albúmina se utiliza como vehículo para el transporte del ácido oleico entre los astrocitos y las neuronas (Tabernero, Lavado, y col. 2001). Es necesario mencionar que la presencia del único doble enlace del ácido oleico es suficiente para incrementar, de forma importante, la fluidez de las membranas biológicas (Alberts y col. 1996), la cual es crítica para las neuronas, por lo que la incorporación de fosfolípidos que contienen oleico puede cambiar sustancialmente las propiedades de la membrana. De acuerdo con esto, el ácido oleico se incorpora preferentemente en las bases de las prolongaciones de las neuritas, lo que sugiere que se requiere un incremento en la fluidez de la membrana en los sitios donde emergen nuevos axones y/o dendritas. Este hecho facilita la formación de la membrana durante el crecimiento neurítico, a la vez que incrementa la flexibilidad para la orientación de los axones (Tabernero, Lavado, $y$ col. 2001). Además, el ácido oleico es el principal ácido graso del sistema nervioso periférico, comprendiendo entre el 35 y el $45 \%$ de los ácidos grasos del nervio ciático. 
La PKC está implicada en la diferenciación neuronal inducida por el ácido oleico, dado que su inhibición previene los efectos neurotróficos del ácido oleico (Tabernero, Lavado, y col. 2001; Granda y col. 2003; Rodríguez-Rodríguez y col. 2004). De hecho, se ha descrito que varios ácidos grasos cis-insaturados, entre los que se incluye el ácido oleico, son capaces de activar la PKC (Khan y col. 1992). Por otra parte, es bien conocido que ciertos factores neurotróficos, como el NGF, activan la PKC y esto induce la expresión de la GAP-43 a través de la estabilización de su mRNA (Perrone-Bizzozero y col. 1993). Asimismo, la PKC colocaliza con la F-actina del citoesqueleto durante el crecimiento de las neuritas e induce el desarrollo de las mismas en células de neuroblastoma (Zeidman y col. 1999). Los factores de transcripción neurogénicos de la familia NeuroD, de tipo bHLH, juegan un importante papel en la neurogénesis y en la diferenciación neuronal (Lee 1997). En ese sentido, el ácido oleico aumenta la expresión del factor de transcripción NeuroD2 (Rodríguez-Rodríguez y col. 2004), una de las isoformas responsables de desencadenar el programa de diferenciación neuronal. Sin embargo, no tiene efecto sobre NeuroD1. Además, la inhibición de la PKC previene también el aumento de la expresión del factor neurogénico NeuroD2 inducido por el ácido oleico (Granda y col. 2003; Rodríguez-Rodríguez y col. 2004).

Recientemente, en nuestro laboratorio hemos descrito que el receptor neuronal del ácido oleico implicado en el proceso de diferenciación es el factor de transcripción PPARa (receptor a activado por proliferadores de peroxisomas) (Bento-Abreu y col. 2007). El ácido oleico ha sido descrito como un ligando natural de la familia de receptores PPAR (Gottlicher y col. 1992). A su vez, cabe destacar que la actividad de PPARa puede estar regulada por PKC a través de residuos fosforilables puesto que la inhibición de la actividad de PKC produce una disminución en la transcripción del gen de PPARa (Blanquart y col. 2004).

Al analizar en conjunto los datos expuestos anteriormente, puede concluirse que la albúmina juega un papel importante en el desarrollo cerebral, induciendo la síntesis del factor neurotrófico ácido oleico.

\subsubsection{Relevancia clínica de la albúmina}

La relevancia clínica de la albúmina en el cerebro ha sido demostrada por un 
gran número de estudios. En este sentido, se ha descrito que la albúmina entra en el cerebro adulto en condiciones de hipoxia y tras daño en la barrera hematoencefálica (Plateel y col. 1997). La capacidad de la albúmina de unión a ligandos juntamente con su capacidad antiedema (Liu y col. 2001), califican a la albúmina como un potente agente neuroprotector. Así, el tratamiento con albúmina, hasta 4 horas después de la lesión isquémica, mejora significativamente la función neurológica y reduce el volumen del infarto en, aproximadamente, un 60\% (Belayev y col. 2001; Liu y col. 2001). De hecho, el uso clínico de la albúmina para el tratamiento de un infarto cerebral agudo se encuentra actualmente en las últimas fases para su aprobación, habiéndose sobrepasado la fase III de ensayos clínicos (Ginsberg y col. 2011). En esa línea, se puede especular con que la albúmina podría tener también un papel importante en la reparación neuronal en respuesta a tales daños, mediante la acción del ácido oleico. Concretamente, se ha demostrado que la SCD-1 y el propio ácido oleico juegan un papel esencial en la regeneración neuronal tras una lesión en el sistema nervioso periférico, mediante un aumento de la expresión de GAP-43 (Breuer y col. 2004). Además, el complejo albúmina-ácido oleico es capaz de ayudar en la recuperación un modelo de lesión de la espinal dorsal, inhibiendo la proliferación de la microglía y estimulando la inervación serotoninérgica (Avila-Martin y col. 2011). Por último, hay que destacar el efecto neuroprotector de la albúmina en la enfermedad de Alzheimer como captador del beta-amiloide (Ahn y col. 2008; Vega y col. 2009). Incluso se ha descrito la presencia de niveles menores de ácido oleico en el cerebro de pacientes con enfermedad de Alzheimer (Cunnane y col. 2012).

\subsubsection{Transporte de la albúmina en el cerebro}

En experimentos realizados anteriormente en nuestro laboratorio observamos que la albúmina era internalizada mediante estructuras vesiculares mediadas por un receptor glicoproteico (Tabernero, Velasco, y col. 2002). En trabajos posteriores hemos descrito que ese receptor glicoproteico es la megalina (Bento-Abreu $y$ col. 2008). Asimismo, hemos descrito que la internalización de la albúmina en el astrocito consiste se produce en un proceso de endocitosis llevado a cabo por caveolinas y mediado por la proteína adaptadora DAB-1 (Bento-Abreu y col. 2009). 
La megalina (o LRP-2/gp33 0) es una glicoproteína monomérica de 600 kDa, perteneciente a la familia de receptores de LDL (LDLDR) y constituye un receptor multiligando de albúmina, lactoferrina, retinol, transcobalamina, proteína de unión de la vitamina $\mathrm{D}$, apolipoproteínas $\mathrm{B}, \mathrm{J}, \mathrm{E}$ y $\mathrm{H}$, lipoproteína lipasa, insulina, hormona paratioidea, mioglobina y calcio, que se expresa principalmente en células polarizadas epiteliales, concretamente en la superficie apical de la membrana (Kounnas y col. 1994).

En el SNC, la megalina se detecta en el neuroepitelio del tubo neural y en la notocorda a partir del día E11. En el día E13, la megalina está presente en el diencéfalo ventral, en la columna vertebral ventral, en la zona ventral del hipocampo y en el plexo coroideo. En el día E15, la expresión de la megalina empieza a restringirse, limitándose al plexo coroideo, zona ventricular de la vesícula ventral lateral, columna vertebral y regiones ventriculares del tercero y cuarto ventrículos (Assémat y col. 2005). Durante el desarrollo postnatal, la megalina se encuentra presente en el plexo coroideo y en zona ventrícular (Polo-Hernández 2009; Medina y Tabernero 2010).Se ha descrito que la megalina en el plexo coroideo del cerebro adulto tiene un papel importante en la neuroprotección al promover la eliminación del ß-amiloide (Zlokovic y col. 1996; Deane y col. 2004; Carro y col. 2005; Tanzi y Bertram 2005).

Se ha descrito como el ratón knockout de megalina presenta anormalidades en el pulmón y el riñón y muere en los días en torno al parto, debido a insuficiencia respiratoria. Además, en el cerebro, la proliferación deficiente del neuroepitelio produce un síndrome holoprosencefálico, caracterizado por la falta de los bulbos olfatorios, la fusión del cerebro anterior y la existencia de un sistema ventricular común (Willnow y col. 1996; Spoelgen y col. 2005). En conjunto, este fenotipo indica que la megalina es esencial para la formación del sistema nervioso y, en general, para el desarrollo.

\subsubsection{La alfa-fetoproteína}

La alfa-fetoproteína (AFP) es una glicoproteína plasmática, producida en el higado fetal y el saco vitelino, perteneciente a la misma familia proteica que la albú- 
mina. La regulación de la expresión de estos genes se produce a nivel transcripcional (Nahon 1987). De hecho, la síntesis de los mRNA de la albúmina y la AFP comienza muy tempranamente en el desarrollo (en torno a E15 en el ratón), siendo las principales proteínas sintetizadas por el hígado fetal. Tras el parto, comienza la represión de la expresión del gen de la AFP mientras que la albúmina permanece transcripcionalmente activa durante toda la vida (para una revisión ver Papaconstantinou y col. 1990). Se cree que, durante el desarrollo, la expresión de los genes de ambas proteínas es activada en elementos reguladores similares presentes dentro de su propia secuencia y, posteriormente, son regulados por procesos de metilación (Muglia y Locker 1984) y elementos específicos de cada uno de sus promotores (Papaconstantinou y col. 1990). La expresión de la AFP puede ser reactivada durante procesos de regeneración hepática o en tumores (Abelev y Eraiser 1999), siendo esta proteína un importante marcador tumoral.

Inicialmente, la AFP se traduce a partir de su mRNA como una AFP inmadura, formada por una cadena polipeptídica de 609 residuos y durante el procesamiento postraduccional se libera un péptido de 18 aminoácidos, obteniendo una AFP de 591 residuos (Terentiev y Moldogazieva 2006).

\subsubsection{Estructura y propiedades de la alfa-fetoproteína}

La AFP de los mamíferos es una glicoproteína formada por una única cadena polipeptídica, con una masa molecular entre 66 y 72 kDa y un contenido en carbohidratos de entre el 3 y el 5\% (la AFP de rata o rAFP tiene una masa entre 69 y 73 kDa, en función del contenido en carbohidratos); no obstante se han descrito otras variantes genéticas minoritarias (Mizejewski 2001).

La estructura de la AFP es muy similar a la de la albúmina. La AFP presenta una estructura secundaria abundante en $\alpha$-hélices y una estructura terciaria con forma de U, formada por tres dominios homólogos (I -III). Los dominios I y III poseen una estructura terciaria rígida y se encuentran unidos por el dominio II, que es más flexible. De hecho, el extremo carboxi-terminal del dominio II posee una región carente de puentes disulfuro, denominada "región bisagra", la cual confiere flexibilidad conformacional a todos los dominios y permite la interacción de la proteína con ligandos y otras proteínas (ver esquema 14, más adelante; para una re- 
visión ver Gillespie y Uversky 2000; Mizejewski 2001; Terentiev y Moldogazieva 2006).

Se ha descrito que la AFP posee una relativa estabilidad de su estructura terciaria, dentro de unos márgenes ( $\mathrm{pH} \mathrm{10,5}$ y 4,5, $\mathrm{T}^{\mathrm{a}}$ inferior a $70^{\circ} \mathrm{C}$, etc), proporcionada por el gran número de puentes disulfuro. Sin embargo, a diferencia de la albúmina, la desnaturalización de la AFP es un proceso irreversible. La irreversibilidad de la desnaturalización es debida a la liberación de los ligandos unidos a la AFP, en presencia de los cuales la AFP presentaría un estructura más rígida (Uversky y col. 1997). La incapacidad de la AFP de revertir a su estado nativo en presencia de los mismos ligandos, una vez desnaturalizada puede ser debida a un efecto cerrojo de los oligosacáridos presentes en esta glicoproteína o, incluso, a su capacidad para formar dímeros (Gillespie y Uversky 2000).

De hecho, se ha sugerido que la AFP podría encontrarse en un cuarto estado conformacional, denominado de "glóbulo fundido", cuando es sometida a condiciones ligeramente desnaturalizantes, lo que implica la liberación de los ligandos unidos.

De esta manera, la AFP unida a sus ligandos naturales (ácidos grasos, estrógenos, etc) presentaría una estructura terciaria rígida, y en ausencia de esos ligandos, presentaría una estructura mas flexible de glóbulo fundido (Gillespie y Uversky 2000). Esta conformación tendría propiedades fisicoquímicas específicas, importantes para las funciones fisiológicas de la AFP, permitiendo el intercambio de ligandos o dejando expuestos determinadas dominios peptídicos (Mizejewski 2001). No obstante, la relevancia, o siquiera existencia, de este estado conformacional en la AFP ha sido debatido por algunos autores a partir de experimentos realizados con AFP recombinante (Leong y Middelberg 2006). 
a)

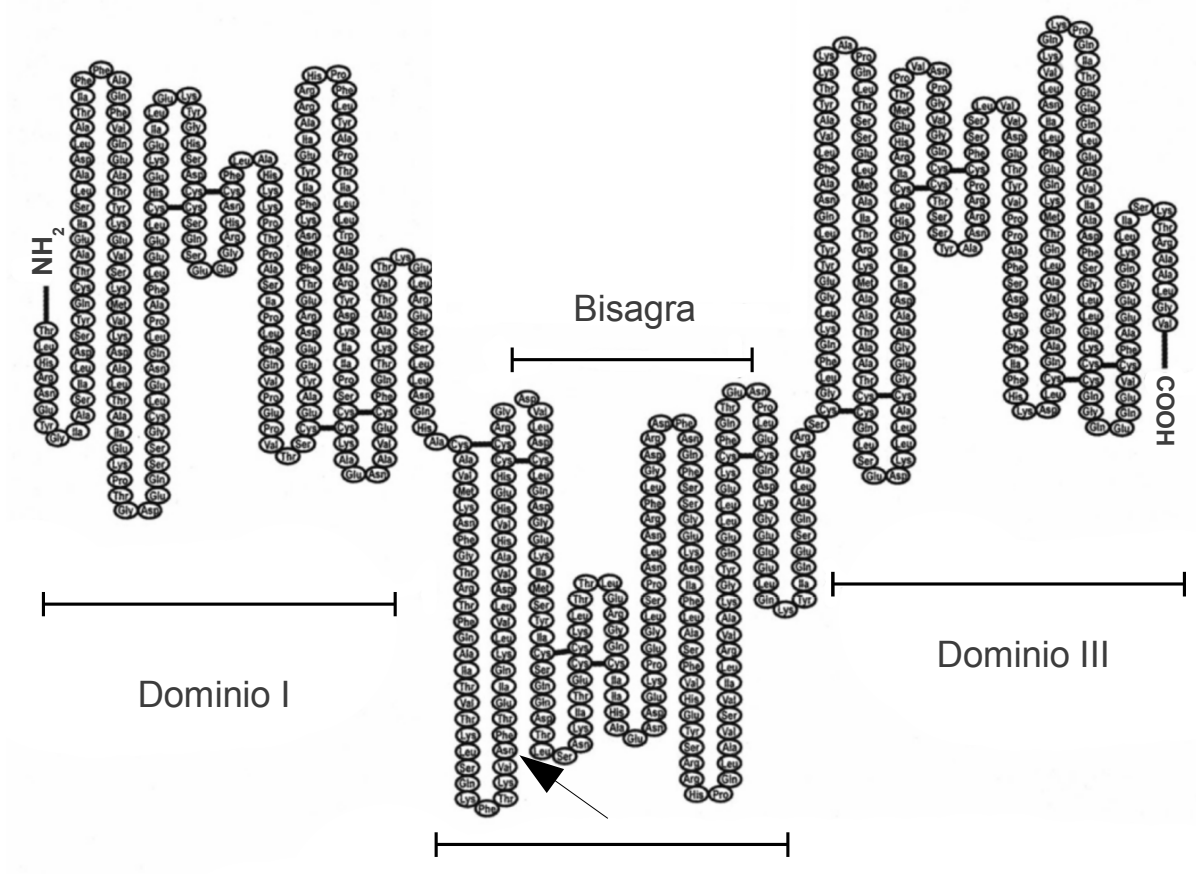

Dominio II

b)

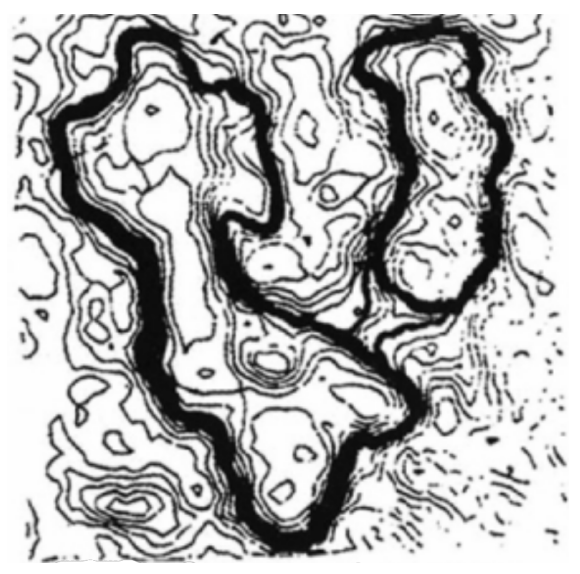

c)

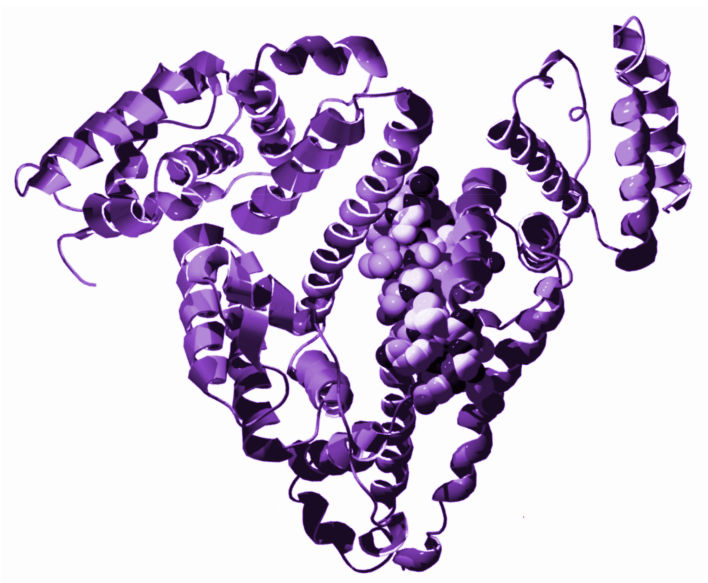

Esquema 14.- Estructura de la AFP. a) Estructura terciaria de la AFP humana (HAFP). La flecha indica el sitio de glicosilación de la HAFP en la Asn 232 y las líneas negras marcan los puentes disulfuro. b) Mapa estructural de la HAFP obtenido mediante difracción electrónica c) Modelo de hélices y lazos de la HAFP. El segmento del dominio II mostrado mediante el modelo de bolas corresponde con al péptido terapéutico GIP34. Esquema modificado de Mizejewski (Mizejewski 2009).

No obstante, las diferencias entre estas proteínas no sólo aparecen a nivel de la secuencia de aminoácidos ya que, a diferencia de la albúmina, la AFP es una glicoproteína que contiene de uno a tres restos de carbohidratos unidos por enlances $\mathrm{N}$-glicosídicos u O-glicosídicos. De esa manera, la AFP humana presenta una 
única glicosilación en la Asn 232 del dominio 2, mientras que la AFP de rata contiene tres restos glicosídicos en la Asn 232, en la Ser 96 (dominio I) y en la Asn 310 (dominio II) (Mizejewski 2001). En ese sentido, muchos autores han sugerido la importancia de las glicosilaciones de la AFP en relación con su función fisiológica (Savu y col. 1977; Park y col. 2010), o como hemos comentado, incluso para su estructura (Gillespie y Uversky 2000). Sin embargo este último punto ha sido puesto en entredicho por otros autores, utilizando para ello AFP recombinante, la cuál está carente de restos glicosilados (Leong y Middelberg 2006).

\subsubsection{Principales funciones}

Se han atribuido numerosas funciones y propiedades in vitro e in vivo a la AFP (Mizejewski 2001; Terentiev y Moldogazieva 2006). En ese sentido, a principios de los 90, Mizejewski y colaboradores desarrollaron la hipótesis del "casete modular" según la cuál la AFP contiene una serie de elementos en forma de secuencias polipeptídicas cortas, los cuáles serían similares a determinados motivos funcionales (para una revisión actualizada ver Mizejewski 2009). Por ejemplo, se ha descrito la presencia en la AFP de secuencias peptídicas similares a las presentes en determinadas proteínas de adhesión como la laminina, la fibronectina, el colágeno, etc (Mizejewski 2001). En ese sentido, la presencia de la AFP durante el desarrollo podría influir en los fenómenos de organogénesis y diferenciación mediante la regulación de la adhesión celular. No obstante, algunas de las aparentes propiedades o actividades de la AFP han resultado ser contradictorias. Existen, por ejemplo, numerosos artículos describiendo propiedades de la AFP sobre el crecimiento celular, tanto estimulantes como inhibitorias. Algunos autores han sugerido que esto puede ser debido a los diferentes métodos utilizados en su purificación, la existencia de cierto grado de desnaturalización, así como la presencia de contaminantes en los preparados (Terentiev y Moldogazieva 2006).

Recientemente se ha desarrollado un ratón knock-out para esta proteína. Sin embargo, el único fenotipo aparente de este animal es la infertilidad de las hembras (Gabant y col. 2002) y una masculinización de los comportamientos sexuales (Bakker y col. 2006). Las glicosilaciones de la AFP parecen jugar un papel importante en este fenotipo, ya que la eliminación de la enzima responsable de la glico- 
silación de la AFP induce un fenotipo muy similar (Park y col. 2010). Sin embargo, cabe destacar que en este modelo, si bien no se han detectado cambios en los niveles de expresión de albúmina, si se ha detectado un aumento muy significativo en la expresión de la alfa-albúmina respecto del animal wild-type (Gabant y col. 2002). La alfa-albúmina es una glicoproteína similar a la AFP y perteneciente igualmente a la familia albuminoide. Aunque las propiedades y funciones de esta proteína no han sido muy estudiadas resulta factible especular con posible efecto compensatorio de la alfa-albúmina en ausencia de la AFP.

\subsection{Transporte de ligandos}

Al igual que la albúmina, la AFP se caracteriza fundamentalmente por la presencia de bolsillos hidrofóbicos que permiten la unión de diferentes ligandos, entre los que destacan los ácidos grasos y estrógenos pero entre los que también se incluyen la bilirrubina o metales como el cobre (Aoyagi y col. 1978, 1979; Iturralde y col. 1991; Nishi y col. 1991).

La capacidad de la AFP de unir ácidos grasos aparece descrita en la bibliografía desde hace mucho tiempo en el ser humano (Parmelee y col. 1978). De igual manera se ha descrito la presencia de ácidos grasos en la AFP en la rata durante el desarrollo (Calvo y col. 1988). De estos estudios se desprende que la AFP transporta mayoritariamente ácidos grasos poliinsturados de cadena larga como el ácido araquidónico (ARA (20:4 (n-6)) y principalmente el ácido docosahexaenoico (DHA, 22:6 (n-3)). También transporta ácidos grasos saturados y monoinsaturados como el ácido palmítico (16:0) y el ácido oleico (18:1 (n-9)). Sin embargo estos dos ácidos grasos son transportados principalmente por la albúmina (Parmelee y col. 1978; Calvo y col. 1988), habiéndose demostrado que la AFP presenta una mayor afinidad para el DHA (Anel y col. 1989). Esos ácidos grasos son susceptibles de ser internalizados, mediante la AFP, por diferentes tipos celulares durante el desarrollo (Uriel y col. 1987; Anel y col. 1990; Iturralde y col. 1991; Torres y col. 1992; Alava y col. 1999).

Asimismo, la AFP es capaz de unir estrógenos (Aussel y col. 1974; Aussel y Masseyeff 1977; Vallette y col. 1977) y es el principal transportador de estradiol, gracias a la presencia de un sitio de gran afinidad para estrógenos (Nishi y col. 
1991). Se ha demostrado cque la AFP es capaz de inhibir el efecto del estradiol impidiendo la unión a su receptor, en el cerebro en desarrollo (Martínez-Cerdeño y col. 2006). En ese sentido, la eliminación de la expresión de la AFP en ratones induce fenotipo de esterilidad en las hembras (Gabant y col. 2002) y mediante este modelo se ha demostrado que la AFP protege al cerebro embrionario de la masculinización y desfeminización inducida por estrógenos (Bakker y col. 2006).

Como ya hemos comentado, la unión de sus ligandos a la AFP induce una configuración terciaria más rígida (Uversky y col. 1997). De hecho inicialmente se había descrito como la AFP podía ser separada en dos formas de punto isoeléctrico diferente en función de si tenían ácidos grasos unidos o no (Parmelee y col. 1978; Vallette y col. 1989). Cabe destacar que los ácidos grasos como el ácido oleico y especialmente poliinsturados como el DHA compiten fuertemente con los estrógenos por su unión a la AFP, llegando a limitar la unión de estos últimos (Benassayag y col. 1979, 1980; Aussel y Masseyeff 1983).

\subsection{Efecto de la alfa-fetoproteína sobre el crecimiento}

El efecto de la AFP sobre la proliferación y diferenciación de diferentes tipos y líneas celulares ha sido ampliamente estudiado, en células ependimales, fibroblastos (Li, Li, Yang, y col. 2002), células hepáticas (Wang y Xie 1998), en el crecimiento uterino (Mizejewski y Warner 1989), la espermatogénesis (Yazama y Tai 2011), etc (para una revisión ver Mizejewski 2001; Terentiev y Moldogazieva 2006). Sin embargo, los datos recogidos al respecto resultan contradictorios ya que se han descrito efectos tanto estimulantes como inhibidores del crecimiento (Dudich y col. 1998). Entre los efectos inhibidores cabe destacar la inhibición de la proliferación de determinados tipos celulares dependientes de estrógenos (Allen y col. 1993; Bennett y col. 1998). En ese sentido parece ser que la inhibición del crecimiento depende del cambio conformacional de la AFP inducido por el estradiol (Mizejewski 1983; Jacobson y col. 1990). Asimismo, esa actividad puede ser inducida por péptidos sintéticos derivados de la AFP (Mesfin y col. 2000; Parikh y col. 2005; Torres y col. 2009). Algunos autores han relacionado estos efectos sobre la proliferación con la presencia de motivos potenciales de heterodimerización con receptores nucleares esteroideos y tiroideos así como con diferentes factores 
de crecimiento (Dauphinée y Mizejewski 2002).

Por último, se ha descrito como la AFP es capaz de regular la muerte celular programada, describiéndose esta como una proteína tanto pro-apoptótica (Dudich y col. 1999, 2000; Um y col. 2004) como anti-apoptótica (Laderoute y Pilarski 1994; Yang y col. 2008; McNutt y col. 2009). La inducción de la apoptosis parece ser un fenómeno dosis dependiente (Dudich y col. 2000), de tal manera que a una concentración elevada, la AFP es capaz de producir la liberación del citocromo-c de la mitocondria y la activación de las caspasas 3 y 9, junto con la formación del complejo del apoptosoma (Dudich y col. 1999; Semenkova y col. 2003).

\subsubsection{La alfa-fetoproteína en el cerebro}

La presencia de la AFP en el cerebro durante el desarrollo es conocida desde hace mucho tiempo (Attardi y Ruoslahti 1976). Desde entonces, numerosos autores han estudiado la presencia, distribución y niveles de la AFP y la albúmina en el cerebro durante el desarrollo tanto en humanos (Jacobsen y col. 1984; Møllgård y col. 1988), como en roedores (Toran-Allerand 1980, 1982; Trojan y Uriel 1980; Ali y col. 1981; Piñeiro y col. 1982), así como en otros mamíferos (Dziegielewska, Evans, Lorscheider, y col. 1981; Kovářů y col. 1984).

Concretamente, en la rata se han descrito unos altos niveles de AFP y niveles algo menores de albúmina en el LCR durante el desarrollo (Dziegielewska, Evans, Lai, y col. 1981). En ese estudio, los autores determinaron que la AFP presenta un pico en torno al día E19 y una posterior caída antes del parto; por otro lado la albúmina permanecería baja hasta el día E17, presentando niveles altos en el LCR durante la primera semana de vida postnatal. Sin embargo, tal y como hemos señalado al principio de la sección 1.3, el paso de proteínas desde el LCR al parénquima cerebral, está regulado por la presencia de la barrera LCR-cerebro (esquema 10).

En ese sentido, mediante estudios inmunohistoquímicos se ha descrito la presencia de la AFP en el interior de células nerviosas en desarrollo (Toran-Allerand 1980, 1982; Trojan y Uriel 1980; Martínez-Cerdeño y col. 2006).

Durante un tiempo existió la controversia acerca del origen de las proteínas 
plasmáticas en el cerebro, habiendo sugerido varios autores que estas proteínas eran sintetizadas localmente (Ali y col. 1982; Ali y Sahib 1983; Dziegielewska y col. 1986). Sin embargo la postural actual de la comunidad científica es la de una ausencia de síntesis de estas proteínas por parte de las células del cerebro (Schachter y col. 1982; Sell y col. 1985; Mizejewski 2004).

Así, y tal como hemos descrito anteriormente, las proteínas plasmáticas son transportadas desde la sangre hasta el LCR a través del plexo coroideo mediante un mecanismo específico (Johansson y col. 2006, 2008; Saunders y col. 2011). Por último, existen evidencias de que las células nerviosas son capaces de internalizar la AFP durante su desarrollo (Uriel y col. 1981, 1983; Toran-Allerand 1987). Sin embargo, la identidad de sus receptores no está clara, a pesar de que la internalización de AFP por diferentes tipos celulares se encuentra ampliamente descrita en la bibliografía (Mizejewski 1994, 1995b; Newby y col. 2005).

\subsubsection{Importancia clínica de la alfa-fetoproteína}

De manera clásica, la AFP ha sido utilizada como un marcador de defectos en el desarrollo fetal tales como la espina bífida, el síndrome de tubo neural abierto y el síndrome de Down (Huang y col. 2010; Wald 2010). Concretamente, en el síndrome de Down, existe una disminución de los niveles de AFP y albúmina producidos por el hígado fetal (Voigtlander y Vogel 1985; Kronquist y col. 1990). Por el contrario, en la ataxia-telengectasia se han descrito niveles mayores de AFP, los cuáles aumentan con la edad (Stray-Pedersen y col. 2007; Braga-Neto y col. 2010).

De igual manera, la AFP se ha propuesto como marcador en la predicción de la fibrosis cística. En esta enfermedad existe un descenso del contenido en DHA, y ello se encuentra en paralelo con unos niveles mas bajos de AFP durante el desarrollo (Mizejewski y Pass 2001).

Sin embargo, durante la vida adulta, la AFP es utilizada como marcador tumoral, principalmente en cánceres hepáticos y gastro-viscerales, ya que se induce en las células tumorales la re-expresion de esta proteína (Abelev y Eraiser 1999; Yokoo y col. 2004; Tsuboi y col. 2006; Moro-Vidal s/f). 
Actualmente, la AFP, así como péptidos sintéticos derivados de ella se están utilizando como fármacos antitumorales directamente o ligados a otros fármacos para su transporte específico a las células tumorales (Jacobson y col. 1990; Moskaleva EYu y col. 1997; Mizejewski 2002, 2007, 2011; Parikh y col. 2005; Bennett y col. 2006; Torres y col. 2009; Aggarwal 2010).

Por último, y tal como hemos comentado anteriormente, la utilización de la AFP como fármaco para el tratamiento de enfermedades autoinmunes se encuentra en una fase avanzada de desarrollo (Chen y Leong 2009). 
Alejandro García García

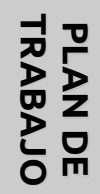


Con el objeto de profundizar en el conocimiento de los puntos expuestos en la introducción, desarrollamos un plan de trabajo consistente en:

1. Determinación de los niveles de alfa-fetoproteína, albúmina y ácido oleico en el cerebro durante el desarrollo embrionario de la rata.

2. Estudio de la localización de la alfa-fetoproteína y de la albúmina en el cerebro durante el desarrollo embrionario y su posible relación con la localización de GAP-43.

3. Desarrollo de un método de obtención y purificación de alfa-fetoproteína de rata.

4. Estudio del efecto de la alfa-fetoproteína en el desarrollo neuronal durante el periodo embrionario. 
Alejandro García García

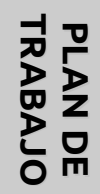


3 MATERIAL Y MÉTODOS 


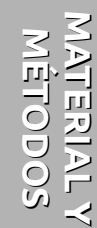




\subsection{MATERIAL}

\subsubsection{Especie ensayada y condiciones del animalario}

Se han empleado ratas albinas Wistar de distintas edades, suministradas por el Servicio de Experimentación Animal de la Universidad de Salamanca.

Los animales se criaron en jaulas. Se mantuvo un ritmo de luz-oscuridad de 12 horas. La humedad osciló entre el 45 y el $65 \%$ y la temperatura se controló entre los 20 y $25^{\circ} \mathrm{C}$. Se alimentaron con una dieta sólida estándar (17\% de proteínas, $3 \%$ de lípidos, $58,7 \%$ de glúcidos, $4,3 \%$ de celulosa, $5 \%$ de minerales y $12 \%$ de humedad). Además, los animales tuvieron en todo momento acceso libre al agua de bebida.

Para el cruce, una rata hembra virgen es colocada junto a dos machos en el mismo espacio durante toda la noche. Al día siguiente se comprueba que la rata ha sido fecundada mediante la observación del frotis vaginal, considerándose como momento "0" del desarrollo, las 12 horas de la noche anterior a la determinación de la fecundación. Por tanto, se ha establecido como criterio que el parto se produce en la rata, tras 21,5 días de gestación

Se emplearon fetos de diferentes edades gestacionales, desde el día 14,5 $(\mathrm{E} 14,5)$ hasta neonatos de 1 día de vida postnatal (P1) para los estudios de desarrollo embrionario del cerebro. Además, se utilizaron embriones de E17,5 para la preparación del cultivo primario de neuronas y neonatos de 1 día de vida postnatal (P1) para la preparación del cultivo primario de astrocitos.

Con el fin de mantener un control preciso de la edad gestacional de los embriones y fetos utilizados se tomaron las medidas del peso total (g), peso de los cerebros tras ser extraídos (g de peso húmedo) y del tamaño de los fetos y embriones (en mm, medidos como la longitud máxima existente del cuerpo del animal). Una vez obtenidos estos datos, se confeccionó una tabla de referencia que sirvió para la inclusión o exclusión de esos mismos animales en los estudios mostrados en el presente trabajo así como en futuras investigaciones del laboratorio.

Los animales se trataron según la normativa española RD 223/88 y la normati- 
va europea 86/609/ECC.

\subsubsection{Medios instrumentales}

El agua utilizada en la realización de los experimentos se purificó mediante un equipo de purificación de agua Milli- $Q^{R}$ Integral 3 System (Millipore Iberica S.A.U., Madrid,España).

Las pesadas se realizaron en una balanza modelo 1207 MP2 y en un granatario modelo ATL 224-I (Sartorius AG., Goettingen, Alemania).

El pH se determinó con un medidor de protones, marca Crison (Selecta, Barcelona, España).

Las centrifugaciones se realizaron en una centrífuga Beckman de mesa modelo TJ-6, una centrífuga Eppendorf, modelo Centrifuge 5415R y una centrífuga Eppendorf, modelo Centrifuge 5702 (Eppendorf Iberica S.L., Madrid, España).

Las cabinas de flujo laminar utilizadas fueron un modelo TC 48 (Gelaire Flow Laboratories, McLean, EE.UU) y una modelo CULTair BC100 (Cultek, S.L.U., Madrid, España).

Los medios de cultivo y los tampones utilizados se esterilizaron a través de filtros de botella de 0,22 $\mu \mathrm{m}$ de tamaño de poro modelo 595-4520 de la casa Nalgene (adquiridos a VWR, VWR International Eurolab S.L., Barcelona, España). Para pequeños volúmenes de soluciones estériles se utilizaron filtros de jeringa de $0,2 \mu \mathrm{m}$ de diámetro de poro (Acrodisc Pall Gelman Laboratory, Michigan, EE.UU).

Para la tripsinización de las células se utilizó un baño termostatizado a $37^{\circ} \mathrm{C}$, modelo Precisterm (Selecta, JP Selecta S.A., Barcelona, España). Para otras aplicaciones a diversas temperaturas, se ha utilizado un bloque térmico para el calentamiento de tubos en seco (Selecta).

El material de vidrio se esterilizó mediante una estufa de esterilización modelo UNE 500 (Memmert, Schwabach, Alemania).

El agua, el material de disección y el resto de los utensilios que requerían asepsia se esterilizaron por medio de calor húmedo en un autoclave modelo 
AES75 Raypa o mediante luz UV para aquellos materiales que no eran resistentes al autoclavado.

Las células se sembraron en placas estériles procedentes de las casas comerciales Nunc (Thermo Scientific, Roskilde, Dinamarca), TPP (TPP Techno Plastic Products AG, Trasadingen, Suiza) y BD Falcon (Becton, Dickinson and Company, Franklin Lakes, NJ, EE.UU).

Las células se mantuvieron en cultivo en un incubador de $\mathrm{CO}_{2}$ modelo Galaxy (RS Biotech, Northants, Reino Unido).

Se utilizaron botellas de oxígeno, nitrógeno y dióxido de carbono suministradas por la Sociedad Castellana de Oxígeno (Valladolid, España).

Las células se observaron periódicamente con un microscopio de contraste de fases, modelo Willovert II pH (Leica, Wetzlar, Alemania) y se contaron con la ayuda del sistema Countess, Automated Cell Counter de Invitrogen (Life Technologies Ltd, Paisley, Reino Unido).

Para la cuantificación de proteínas de las muestras procedentes del proceso de purificación de la alfa-fetoproteína se utilizó un sistema espectrofotométrico Nanophotometer de la casa Implen (Munich, Alemania). La cuantificación de las proteínas de las muestras procedentes de tejido cerebral se cuantificaron usando un lector de placas Thermo Electron Appliskan (Thermo Scientific, Roskilde, Dinamarca) mediante el método de Bradford. Las muestras procedentes de los cultivos celulares y organotípicos fueron cuantificadas utilizando el dispositivo fluorimétrico Qubit $®$ de Invitrogen (Life Technologies Ltd, Paisley, Reino Unido).

Para la realización del ensayo colorimétrico con bromuro de 3-(4,5-dimetiltiazol-2-il)-2,5- difenil-tetrazolio (MTT) se utilizó un lector de placas Thermo Electron Appliskan (Thermo Scientific, Roskilde, Dinamarca).

Para los análisis de transferencia tipo "Western" se utilizó un sistema de electroforesis vertical y un sistema de electrotransferencia modelo "Mini Trans-Blot Transfer Cell" conectado a una fuente de alimentación modelo "PowerPac 300" de Bio-Rad (Hercules, CA, EE.UU). También se usaron un sistema de electroforesis X4 Cell Sure Lock Midi Cell y un sistema de transferencia semi-húmeda iBlot de 


\section{Alejandro García García}

Invitrogen (Life Technologies Ltd, Paisley, Reino Unido).

Las incubaciones de las membranas de nitrocelulosa o de PVDF con anticuerpos primarios o secundarios se realizaron en un sistema magnético de rotación vertical, Navigator (Fredericton, Canada).

Para la sonicación de las muestras empleadas en la transferencia tipo "Western" se utilizó un baño de sonicación modelo Bandelin Sonorex.(Bandelin GmbH \& Co. KG, Berlin, Alemania).

El criostato utilizado para la microsección de cerebros fue el modelo Microm HM550 de Thermo Scientific (Thermo Scientific, Roskilde, Dinamarca).

La lupa empleada en el proceso de obtención del tejido para los cultivos organotípicos fue el modelo MSZ800 de Nikon (Barcelona, España).

Las pinzas, tijeras y material de disección fino utilizado para el estudio de cerebro y preparación de los cultivos organotípicos fue adquirido en la casa comercial Fine Science Tools (F.S.T, Heidelberg, Alemania).

Para los experimentos con moléculas fluorescentes se empleó un microscopio invertido de fluorescencia, modelo Eclipse T2000S (Nikon Europe B.V., Badhoevedrop, Holanda). Las imágenes microscópicas se captaron con una cámara de vídeo digital Leica DC 100, acoplada al microscopio invertido (Leica Microsistemas S.L.U., Barcelona, España).

Para la microscopía confocal se utilizó un microscopio confocal modelo Leica SP2 del Instituto de Neurociencias de Castilla y León. Las imágenes se analizaron empleando el programa Leica LCS lite.

El sistema HPLC utilizado en el análisis de ácidos grasos se compone de un módulo inyector y un módulo de distribución de solventes modelo 125 , System Gold. El detector ultravioleta "diode array" es el modelo 168, System Gold. El aparato proviene de la firma comercial Beckman Instruments (IZASA Distribuciones Técnicas S.A. Barcelona España).

La fase estacionaria que permitió la separación de los ácidos grasos es una columna de fase reversa, de 4,6 mm x $250 \mathrm{~mm}$, con partículas de sílica C-18 de 5 $\mu \mathrm{m}$ de diámetro, modelo Ultrasphere-ODS de Scharlau (Scharlab, Barcelona, Es- 
paña).

El computador que integraba la señal proveniente del sistema de HPLC es un Dell Optiplex Gs (Barcelona, España).

Para el análisis y tratamiento de imágenes se utilizaron el programa de dominio público ImageJ (rsbweb.nih.gov/ij) y el programa de edición de imágenes digitales de código abierto GIMP (GNU Image Manipulation Program, www.gimp.org).

\subsubsection{Productos.}

Los productos utilizados en la preparación de disoluciones y tampones que no se detallan a continuación, fueron adquiridos en las casas comerciales Sigma (Sigma-Aldrich Química, Madrid, España) o Merck (Merck KGaA, Darmstadt, Alemania).

\subsubsection{Productos utilizados para la preparación de los cultivos celulares}

El medio de cultivo de astrocitos y de células de hepatoma procedía de la casa Sigma (D5523) y es del tipo DMEM (Medio de Eagle modificado por Dulbecco).

El medio de cultivo de neuronas procedía de la casa Sigma (D6421) y es del tipo DMEM-F12 (Medio de Eagle modificado por Dulbecco, suplementado con mezcla de nutrientes F-12), Ham.

La L-glutamina (G5763), la apotransferrina (T0178), el piruvato sódico (P2256) y la insulina (I663) utilizadas para la preparación del medio definido, fueron adquiridos a Sigma.

La penicilina G, (P3032), la estreptomicina (S9137) y la anfotericina (A9528) para la preparación de la mezcla de antibióticos procedieron de la casa Sigma.

El suero fetal bovino (FBS, 10270) procedía de la casa Gibco (Life Technologies Ltd, Paisley, Reino Unido).

Para la preparación de los cultivos celulares se emplearon DNAsa I (10104159001) y albúmina (fracción V, 107350780001) suministradas por Roche Diagnostics S.L. (Barcelona, España), así como tripsina, suministrada por Sigma 
(T4799).

La poli-L-lisina con la que se recubrió el fondo de las placas de cultivo fue adquirida a la casa comercial Sigma (P1524).

La citosina- $\beta$-arabinofuranósido empleada en los cultivos de astrocitos procedía de Sigma (C6645)

\subsubsection{Productos utilizados para la preparación de los cultivos tisulares}

EI HEPES (15630-049) utilizado en la preparación del tampón Krebs y el MEM (medio mínimo esencial de Eagle, 31095) procedían de la casa Invitrogen (Life Technologies).

El medio de cultivo de organotípicos es del tipo Neurobasal (21103) y el suplemento sustitutivo de suero B27 (17504-044) fueron adquiridos en GIBCO (Life Technologies); la glutamina y la glucosa, fueron adquiridas a Sigma.

Los moldes utilizados para la encastración de los cerebros (70181) son de la casa Aname (Aname, S.L Madrid, España).

La agarosa de bajo punto de fusión utilizada para encastrar los cerebros fue del tipo "Sea Plaque Agarose" de la casa Lonza. (50101).

Se utilizaron filtros de policarbonato modelo Nuclepore Track-Etched Membranes de $8,0 \mu \mathrm{m}$ de tamaño de poro y $13 \mathrm{~mm}$ de diámetro, de la marca Whatman (VWR 515-2014).

\subsubsection{Productos utilizados en la diálisis de la albúmina libre de ácidos grasos}

La membrana utilizada para dializar la albúmina fue adquirida en Sigma (D0655-100FT). Igualmente, el sulfuro sódico (407410) y el ácido sulfúrico 96\% $(\mathrm{v} / \mathrm{v})$, empleados para el tratamiento previo de dicha membrana, procedieron de Sigma y de Merck, respectivamente.

Los filtros $(0,22 \mu \mathrm{m})$ utilizados para la esterilización de la albúmina dializada son de la marca Serum Acrodisc (Pall Gelman Laboratory). 
La albúmina sérica bovina (BSA) esencialmente libre de ácidos grasos fue suministrada por Sigma (A7030).

\subsubsection{Productos utilizados para la preparación de la alfa- fetoproteína}

Para la concentración inicial del medio de hepatoma para la purificación de alfa-fetoproteína (AFP) se empleó un dispositivo Pellicon XI Biomax -50 PXB050A50 (Millipore), que posee un tamaño de exclusión molecular de 50 kDa y una bomba peristáltica de flujo variable Masterflex L/S modelo 7554-85 con un cabezal "Easy Load" modelo 7518-00 (Cole-Parmer Instrument Company, IL EE.UU).

Para la retirada de la albúmina en el proceso de purificación de AFP se utilizaron unas columnas de afinidad Bio-Scale Mini Affi-Gel Blue de $5 \mathrm{~mL}$, de Bio-Rad y una bomba para jeringa de flujo regulable, modelo NE-300 (New Era Pump Systems Inc. Farmingdale, NY, EE.UU).

Para la concentración final de la AFP se utilizó un filtro de centrífuga de tubo cónico, Amicon Ultra-15 Ultracel 50K UFC8 05024 (Millipore), con un tamaño de exclusión molecular de 50 kDa.

Para la diálisis final de la AFP se utilizaron unos casetes de microdiálisis modelo Slide-A-Lyzer (87735), de la casa Thermo Scientific.

\subsubsection{Productos utilizados para el análisis de las proteínas}

Para la extracción de proteínas se empleó un cóctel de inhibidores de proteasas (539134) adquirido a la casa comercial Calbiochem (Merck KgaA) y fenilmetanosulfonil fluoruro (PMSF) obtenido de la casa Sigma (P7626).

El reactivo Bradford para la determinación de proteínas (Bio-Rad Protein Assay, 500-0006), la solución de acrilamida/Bis 30\% (29:1) (161-0156) para la preparación de geles para la electroforesis de proteínas y los marcadores de peso molecular de proteínas (161-0374) procedían de Bio-Rad.

El N,N,N',N'-tetrametiletilendiamina (TEMED, T9281) y el persulfato amónico (AMPS, A3678) utilizados en la preparación de los geles procedieron de la casa 


\section{Alejandro García García}

Sigma.

Las proteínas se electrotransfirieron a membranas de nitrocelulosa de 0,45 $\mu \mathrm{m}$ de tamaño de poro (162-0093, Bio-Rad) o a membranas de difluoruro de polivinilideno (PVDF, IPVH00010, Millipore) en aquellas ocasiones en que se utilizó el sistema Mini-Protean III. El metanol utilizado en la preparación del tampón de transferencia húmeda procedió de la casa comercial Panreac Química S.A. (Barcelona, España).

Los geles de gradiente acrilamida 4\%-12\% precast (WG1402BOX), el tampón de carga (NP0007), el agente reductor (NP0004), el antioxidante (NP0005) y el tampón de electroforesis MOPS-SDS (NP0001) utilizados con el sistema Novex se adquirieron en la casa Invitrogen (Life Technologies S.A. Madrid, España). Asimismo se adquirieron en esa casa comercial las membranas de nitrocelulosa utilizadas con el sistema iBlot de transferencia seca.

El anticuerpo monoclonal de ratón contra GAP-43 (G9264) y el anticuerpo monoclonal de ratón contra MAP-2 (M1406) se adquirieron en Sigma.

El anticuerpo policlonal de conejo contra la albúmina sérica bovina (126620) procedía de la casa Calbiochem (Merck KgaA).

El anticuerpo policlonal contra la albúmina sérica de rata (64-562) procedía de la casa ICN Biomedical (Life Technologies).

El anticuerpo policlonal contra la AFP humana se obtuvo de la casa DAKO (A0008 Dako Diagnósticos, S.A. Barcelona, España).

El anticuerpo monoclonal de ratón contra la gliceraldehido-3-fosfato deshidrogenasa (GAPDH, AM4300) se adquirió en la casa Ambion (Life Technologies).

El anticuerpo monoclonal de ratón contra la alfa-tubulina (T9026) provenía de la casa Sigma.

El anticuerpo monoclonal de rata contra la bromodesoxiuridina (BrdU) procedía de la casa comercial Accurate Chemical \& Scientific Corporation (Leti Laboratorios, Barcelona, España).

Los anticuerpos secundarios contra inmunoglobulina de ratón (SC 2005) y co- 
nejo (SC 2030) conjugados con peroxidasa y el sustrato quimioluminiscente luminol provinieron de la casa Santa Cruz Biotechnology, Inc (Santa Cruz, EE.UU).

Las películas de autorradiografía para la determinación de la quimioluminiscencia fueron películas médicas de Rayos- $X$ de la marca Fujifilm (Madrid, España).

El paraformaldehído y el metanol utilizado para fijar las células procedían de la casa Merck.

La sacarosa para proteger los cerebros fue adquirida en Merck.

Los cerebros se encastraron en Tissue-Tek ® O.C.T, de la marca Sakura (Sakura Finetek Europe B.V., Holanda).

\begin{tabular}{|c|c|c|c|c|}
\hline Marcador & Donador & Tipo & Concentración & Procedencia \\
\hline $\begin{array}{c}\text { Alfa- } \\
\text { fetoproteína }\end{array}$ & Conejo & Policlonal & $\begin{array}{c}1: 1.000 \mathrm{WB} \\
1: 500 \mathrm{IQ}\end{array}$ & DAKO \\
\hline $\begin{array}{c}\text { Albúmina } \\
\text { sérica bovina. }\end{array}$ & Conejo & Monoclonal & $1: 1.000$ & Chemicon \\
\hline $\begin{array}{c}\text { Albúmina } \\
\text { sérica de rata. }\end{array}$ & Conejo & Policlonal & $1: 500$ & $\begin{array}{c}\text { ICN Biomedi- } \\
\text { cal }\end{array}$ \\
\hline BrdU & Rata & Policlonal & $1: 400$ & $\begin{array}{c}\text { Accurate } \\
\text { Chemical }\end{array}$ \\
\hline GAP-43 & Ratón & Monoclonal & $1: 500$ & Sigma \\
\hline GAP-43 & Conejo & Policlonal & $1: 500$ & Abcam \\
\hline MAP-2 & Ratón & Monoclonal & $1: 500$ & Sigma \\
\hline GAPDH & Ratón & Monoclonal & $1: 2.000$ & Ambion \\
\hline Tubulina & Ratón & Monoclonal & $1: 4.000$ & Sigma. \\
\hline
\end{tabular}

Tabla 1.- Anticuerpos primarios utilizados para la detección de proteínas en transferencia tipo western, inmunocitoquímica e inmunohistoquímica. Abreviaturas: WB, Western Blot o transferencia tipo "Western"; IQ, Inmunocitoquímica e inmunohistoquímica.

El medio de montaje para observaciones al microscopio SlowFade Gold antifade reagent, el marcador fluorescente del DNA 4,6-diamidino-2-fenilindol (DAPI) y el To-Pro3, otro marcador fluorescente del DNA, fueron suministrados por Invitrogen (Life Technologies). 


\section{Alejandro García García}

Los anticuerpos secundarios conjugados con Alexa Fluor 488 o Alexa Fluor 594 contra inmunoglobulina de ratón, o conejo fueron suministrados por Invitrogen (Life Technologies). El anticuerpo secundario contra la inmunoglobulina de rata conjugado con el fluoróforo Cy3 se obtuvo de la casa comercial Jackson Immunoresearch (Baltimore, EE.UU).

El detergente Triton-X-100 para la permeabilización del tejido fue suministrado por la casa Sigma.

Los portaobjetos y cubreobjetos utilizados para el montaje de secciones de tejido, fueron adquiridos en la casa comercial Thermo Scientific.

\begin{tabular}{|c|c|c|c|c|}
\hline Marcador & Donador & Conjugado & Concentración & Procedencia \\
\hline a IgG de Ratón & Cabra & HRP & $1: 5.000$ & Santa Cruz \\
\hline a IgG de Conejo & Cabra & HRP & $1: 10.000$ & Santa Cruz \\
\hline a lgG de Ratón & Cabra & Alexa 488 & $1: 1.000$ & Invitrogen \\
\hline a lgG de Ratón & Cabra & Alexa 594 & $1: 1.000$ & Invitrogen \\
\hline a IgG de Conejo & Cabra & Alexa 488 & $1: 1.000$ & Invitrogen \\
\hline a IgG de Conejo & Cabra & Alexa 594 & $1: 1.000$ & Invitrogen \\
\hline a IgG de Rata & Cabra & Су3 & $1: 1.000$ & $\begin{array}{c}\text { Jackson } \\
\text { Immunoresearch }\end{array}$ \\
\hline
\end{tabular}

Tabla 2.- Anticuerpos secundarios utilizados para la detección de proteínas en transferencia tipo wes tern, inmunocitoquímica e inumonohistoquímica. Abreviaturas HRP: Peroxidasa de rábano (Horseradish peroxidase).

\subsubsection{Productos empleados para el análisis de los ácidos grasos}

Los disolventes orgánicos metanol, cloroformo, n-hexano y acetonitrilo, empleados en la extracción de ácidos grasos, y el $\mathrm{KHCO}_{3}$, empleado en el proceso de derivatización, se adquirieron en Merck.

El antioxidante de ácidos grasos BHT (2,6-di-ter-butil-4-metilfenol, B1378), el ácido graso que sirvió de estándar interno, ácido margárico (H3500), así como el ácido oleico (01383) y el ácido palmítico (P5585), utilizados como patrones, pro- 
cedían de Sigma.

El producto para la derivatización de los ácidos grasos, PBPB (2,4-dibromoacetofenona, D38308), y el catalizador, 18-crown-6 $(1,4,7,10,13,16$-hexaxociclooctadecano, C5515), pertenecían a la casa Sigma.

\subsubsection{Productos empleados en la determinación de la} viabilidad y proliferación celulares

El 3-(4,5-dimetiltiazol-2-il)-2,5-difenil-tetrazolio (MTT, M5655) para la determinación de la viabilidad general de las células fue suministrado por Sigma.

Los reactivos para la preparación del tampón TUNEL, $\mathrm{CoCl}_{2}, \mathrm{C}_{2} \mathrm{H}_{6} \mathrm{AsO}_{2} \mathrm{Na}$, Triton X-100 y el tampón Tris pH 7,2, así como el tampón SSC (citrato de sodio) fueron adquiridos en la casas Sigma y Merck.

El dUTP y la desoxinucleotidiltransferasa terminal empleadas en el ensayo de TUNEL fueron adquiridos en la casa Roche (Roche Diagnostics, Barcelona, España).

El ioduro de propidio (P4170) utilizado para marcar el DNA fue suministrado por Sigma.

La bromodesoxiuridina utilizada (BrdU) fue obtenida de la casa BD (BD Biosciences, Madrid, España).

La estreptavidina conjugada con Cy2 fue adquirida a la casa Jackson Immunoresearch

\subsection{MÉTODOS}

\subsubsection{Preparación de los cultivos celulares}

\subsubsection{Preparación del cultivo primario de neuronas}

Los cultivos de neuronas se realizaron según el método previamente descrito por Tabernero y col (Tabernero y col. 1993). Los fetos se obtuvieron por cesárea 


\section{Alejandro García García}

post mortem de la madre gestante en el día 17,5 de gestación $(\mathrm{E} 17,5)$. Todo el proceso se realizó en condiciones de esterilidad y a temperatura ambiente, con excepción de la tripsinización, que se llevó a cabo a $37^{\circ} \mathrm{C}$.

Los fetos se limpiaron con etanol al $70 \%$, se decapitaron y se extrajeron los cerebros, de los que se retiraron las meninges y los vasos sanguíneos visibles. Los cerebros se colocaron en una placa petri que contenía solución " $A$ " (EBSS pH 7,2 suplementado con DNAsa tipo I $20 \mu \mathrm{g} / \mathrm{mL}$ y albúmina (fracción V) $3 \mu \mathrm{g} / \mathrm{mL}$ ). La solución EBSS, o disolución de Earle, estaba compuesta por: $\mathrm{NaCl} 116 \mathrm{mM}, \mathrm{KCl}$ 5,4 mM, NaH $\mathrm{PO}_{4} 1,0 \mathrm{mM}, \mathrm{MgSO}_{4} 1,5 \mathrm{mM}, \mathrm{NaHCO}_{3} 26 \mathrm{mM}$, rojo fenol $10 \mathrm{mg} / \mathrm{L}$ y D-glucosa $14 \mathrm{mM}$ a un $\mathrm{pH}$ 7,2. El tejido en solución "A" se disgregó utilizando un bisturí y posteriormente se centrifugó durante 2 minutos a $500 \times \mathrm{g}$. El tejido disgregado se incubó durante 15 minutos a $37^{\circ} \mathrm{C}$ en solución "B" (EBSS pH 7,2 suplementado con tripsina $0,25 \mu \mathrm{g} / \mathrm{mL}$, DNAsa tipo I $60 \mu \mathrm{g} / \mathrm{mL}$ y albúmina fracción $\mathrm{V}$, $3 \mu \mathrm{g} / \mathrm{mL}$ ). Posteriormente, se detuvo la tripsinización añadiendo al tejido disgregado DMEM suplementado con FBS al 10\% (v/v). Finalizada la tripsinización, se centrifugó el tejido durante 5 minutos a $500 \times$ g, se retiró el sobrenadante, se resuspendió el tejido en la solución A y se hizo pasar varias veces a través de una pipeta pasteur siliconada. Se esperó entonces 4 minutos y se recogió el sobrenadante repitiendo dos veces más ese tratamiento. Se reunieron los sobrenadantes y se centrifugaron a $500 \times g$ durante 5 minutos. Las células obtenidas se resuspendieron en medio de cultivo de neuronas, designado medio definido (DMEM-HF12 suplementado con piruvato sódico $1 \mathrm{mM}$, apotransferrina $100 \mu \mathrm{g} / \mathrm{mL}$, L-glutamato $2,5 \mathrm{mM}$, insulina $5 \mu \mathrm{g} / \mathrm{mL}$ y una mezcla de antibióticos consistente en penicilina $\mathrm{G} 50 \mathrm{U} / \mathrm{mL}$, estreptomicina $37,5 \mathrm{U} / \mathrm{mL}$, y anfotericina $B \quad 0,23 \mu \mathrm{g} / \mathrm{mL}$ todo ello a $\mathrm{pH} 7,2)$.

Una pequeña alícuota de esta suspensión celular se mezcló con azul de tripano al $0,2 \%(p / v)$ para la determinación de la viabilidad celular y del número de células.

A continuación, las células se sembraron en placas petri recubiertas con poli-Llisina $(1 \mu \mathrm{g} / \mathrm{cm} 2)$, en medio definido. Las células se sembraron a una densidad de $1,5 \times 10^{5}$ células $/ \mathrm{cm}^{2}$ en placas de $35 \mathrm{~mm}$ de diámetro en un volumen total de 1 
$\mathrm{mL}$. Las células se mantuvieron en un incubador a $37^{\circ} \mathrm{C}$, con un $5 \%$ de CO2. En estas condiciones se obtienen cultivos de neuronas de una pureza del 95\%, a juzgar por su reacción con el anticuerpo específico contra el neurofilamento (Vicario y col. 1993).

\subsubsection{Preparación del cultivo primario de astrocitos}

Los cultivos de neuronas se realizaron según el método previamente descrito por Tabernero y col (Tabernero y col. 1993). Se emplearon neonatos de un día de vida postnatal (P1). Todo el proceso se realizó en condiciones de esterilidad y a temperatura ambiente, con excepción de la tripsinización, que se llevó a cabo a $37^{\circ} \mathrm{C}$.

Los animales se limpiaron con etanol al $70 \%$, se decapitaron y se extrajeron los cerebros, de los que se retiraron las meninges y los vasos sanguíneos visibles. Los cerebros se colocaron en una placa petri que contenía solución "A" (EBSS pH 7,2 suplementado con DNAsa tipo I $20 \mu \mathrm{g} / \mathrm{mL}$ y albúmina (fracción V) 3 $\mu \mathrm{g} / \mathrm{mL})$. La solución EBSS, o disolución de Earle, estaba compuesta por: $\mathrm{NaCl}$ $116 \mathrm{mM}, \mathrm{KCl}$ 5,4 mM, NaH $\mathrm{PO}_{4}$ 1,0 mM, MgSO4 1,5 mM, NaHCO 326 mM, rojo fenol $10 \mathrm{mg} / \mathrm{L}$, D-glucosa $14 \mathrm{mM}$ a un pH 7,2. El tejido en solución "A" se disgregó utilizando un bisturí y posteriormente se centrifugó durante 2 minutos a $500 \mathrm{x} \mathrm{g}$. El tejido disgregado se incubó durante 15 minutos a $37^{\circ} \mathrm{C}$ en solución "B" (EBSS $\mathrm{pH} 7,2$ suplementado con tripsina $0,25 \mu \mathrm{g} / \mathrm{mL}$, DNAsa tipo I $60 \mu \mathrm{g} / \mathrm{mL}$ y albúmina fracción $\mathrm{V}, 3 \mu \mathrm{g} / \mathrm{mL}$ ). Posteriormente, se detuvo la tripsinización añadiendo al tejido disgregado DMEM suplementado con FBS al 10\% (v/v). Finalizada la tripsinización se centrifugó el tejido durante 5 minutos a 500 x g, se retiró el sobrenadante, se resuspendió el tejido en la solución $A$ y se hizo pasar varias veces a través de una pipeta pasteur siliconada. Se esperó entonces 4 minutos y se recogió el sobrenadante repitiendo dos veces más ese tratamiento. Se reunieron los sobrenadantes y se centrifugaron a $500 \times g$ durante 5 minutos. Las células obtenidas se resuspendieron en medio de cultivo (DMEM suplementado con FBS al 10\% (v/v), penicilina $\mathrm{G} 50 \mathrm{U} / \mathrm{mL}$, estreptomicina $37,5 \mathrm{U} / \mathrm{mL}$ y anfotericina $\mathrm{B} 0,23 \mu \mathrm{g} / \mathrm{mL}$ a $\mathrm{pH}$ $7,2)$.

Una pequeña alícuota de esta suspensión celular se mezcló con azul de tripa- 


\section{Alejandro García García}

no al $0,2 \%(p / v)$ para la determinación de la viabilidad celular y del número de células.

A continuación, se sembraron las células en medio de cultivo, en placas petri recubiertas con poli-L-lisina $\left(1 \mu \mathrm{g} / \mathrm{cm}^{2}\right)$, a una densidad de $1,0 \times 10^{5}$ células $/ \mathrm{cm}^{2}$ en placas de 12 pocillos en un volumen total de $1 \mathrm{~mL}$ de medio. Posteriormente las células se colocaron en un incubador a $37^{\circ} \mathrm{C}$, con un $5 \% \mathrm{CO}_{2}$. Al tercer día, con el fin de evitar la proliferación de la microglía y de las células del linaje O-2A, se añadió citosina $\beta$-arabinofuranósido $10 \mu \mathrm{M}$, que se mantuvo durante 48 horas (Tabernero y col. 1996). Los cambios de medio se realizaron dos veces por semana con medio de cultivo. En estas condiciones se obtienen cultivos de astrocitos de tipo-1 de una pureza del 95\%, a juzgar por su reacción con el anticuerpo específico anti-GFAP (Tabernero y col. 1996)).

\subsubsection{Preparación del cultivo de células de hepatoma de rata McA-RH 7777}

Las células de hepatoma de rata McA-RH 7777 se obtuvieron a partir de alícuotas congeladas, donadas generosamente por la Dra. Da María Ángeles Serrano del Departamento de Bioquímica y Biología Molecular de la Universidad de Salamanca. Las células se sembraron en DMEM (Sigma 5523) al que se añaden Dglucosa al $0,45 \% \mathrm{p} / \mathrm{v}$ de concentración final, $\mathrm{HCO}_{3}$ al $0,15 \%$, una mezcla de antibióticos (penicilina G $50 \mathrm{U} / \mathrm{mL}$, estreptomicina 37,5 U/mL, anfotericina B 0,023 \%) y suero fetal bovino inactivado al $10 \%$, en botellas de plástico de superficie creciente $\left(25 \mathrm{~cm}^{2}, 75 \mathrm{~cm}^{2}\right.$ y $\left.150 \mathrm{~cm}^{2}\right)$

Las células se sembraron inicialmente, tras la descongelación, en placas de 90 $\mathrm{mm}$ de diámetro para su proliferación y, posteriormente, se resembraron en frascos de cultivo de $150 \mathrm{~cm}^{2}$, a una densidad aproximada de entre 1:4 y 1:6 de la inicial. El medio de cultivo se cambia cada 3 días aproximadamente, hasta que las células alcanzan el $75 \%$ de confluencia, momento en el cuál las células se resembraron y congelaron nuevamente.

Para la resiembra de las células de hepatoma, las células se lavaron 2 veces con PBS y se incubaron con tripsina/EDTA durante 1 minuto a $37^{\circ} \mathrm{C}$. Se recogie- 
ron en DMEM + FBS 10\% (v/v) para finalizar la tripsinización y se centrifugaron durante 5 minutos a $500 \times \mathrm{g}$. Se retiró el sobrenadante y se resuspendió el precipitado en $1 \mathrm{~mL}$ de DMEM + FBS 10\% fresco y, posteriormente, en el volumen final de siembra.

Las células de hepatoma se congelaron a $-80^{\circ} \mathrm{C}$, a una densidad de $1 \times 10^{6}$ $\mathrm{cel} / \mathrm{mL}$, manteniendo las células en crioviales con un medio crioprotector consistente en FBS + DMSO 10\% (v/v).

El tratamiento de estas células se detalla en la sección 3.2.4.1.

\subsubsection{Preparación de los cultivos tisulares}

\subsubsection{Preparación de los cultivos organotípicos de rodajas de cerebro}

Los cultivos organotípicos se prepararon siguiendo el protocolo utilizado en el laboratorio del Dr. D. Oscar Marín (Instituto de Neurociencias de Alicante), con algunas modificaciones.

Para los cultivos organotípicos se emplearon fetos de rata de E17,5. Los fetos se obtuvieron por cesárea post mórtem de la madre gestante y se mantuvieron en medio Krebs ( $\mathrm{NaCl} 126$ mM, KCl 2,5 mM, NaH${ }_{2} \mathrm{PO}_{4} 1,2 \mathrm{mM}, \mathrm{MgCl}_{2}$ 1,2 mM, CaCl $2,1 \mathrm{mM}$, glucosa $11 \mathrm{mM}$ y $\mathrm{NaHCO}_{3} 25 \mathrm{mM}$ ) filtrado a $4{ }^{\circ} \mathrm{C}$. Los cerebros se extrajeron, se colocaron en moldes y se embebieron en agarosa al 4\% en PBS estéril. Una vez embebidos, los cerebros fueron cortados en secciones coronales de 250 $\mu \mathrm{m}$ en el vibratomo en medio Krebs frío. Las secciones se recolectaron y se transfirieron a microplacas que contenían medio Krebs estéril (HEPES 0,1 M, penicilina G $50 \mathrm{U} / \mathrm{mL}$, estreptomicina $37,5 \mathrm{U} / \mathrm{mL}$, y anfotericina $B \quad 0,23 \mu \mathrm{g} / \mathrm{mL}$ en medio Krebs, esterilizado mediante un filtro de 0,2 $\mu \mathrm{M})$. A continuación, en la cabina de flujo laminar, se transfirieron las rodajas a unas membranas de policarbonato en placas de 12 pocillos que contenían medio MEM (50\% de glucosa y penicilina G $50 \mathrm{U} / \mathrm{mL}$, estreptomicina $37,5 \mathrm{U} / \mathrm{mL}$ en MEM a medium glutamax) donde se incubaron durante 1 hora a $37^{\circ} \mathrm{C}, 5 \% \mathrm{CO}_{2}$. Posteriormente se cambió el medio por medio Neurobasal (B27 $20 \mu \mathrm{L} / \mathrm{mL}, 50 \%$ de glucosa y penicilina G $50 \mathrm{U} / \mathrm{mL}$, es- 


\section{Alejandro García García}

treptomicina $37,5 \mathrm{U} / \mathrm{mL}$, y anfotericina $\mathrm{B} 0,23 \mu \mathrm{g} / \mathrm{mL}$ en medio Neurobasal). Por último las rodajas se colocaron en un incubador a $37^{\circ} \mathrm{C}$, con un $5 \% \mathrm{CO}_{2}$ durante 48 horas.

\subsubsection{Preparación de la albúmina libre de ácidos grasos}

La albúmina empleada en los experimentos descritos a lo largo de esta Memoria fue albúmina sérica bovina libre de ácidos grasos, previamente dializada en solución de Elliot (Elliott 1969) ( $\mathrm{NaCl} 122 \mathrm{mM}, \mathrm{KCl}$ 4,8 mM, KH $\mathrm{PO}_{4}$ 0,4 mM, Mg$\mathrm{SO}_{4} 1,2 \mathrm{mM}, \mathrm{CaCl} 21,3 \mathrm{mM}$, preparado en tampón fosfato sódico $10,8 \mathrm{mM}, \mathrm{pH}$ $7,6)$.

Para el tratamiento de la membrana de diálisis se siguieron las instrucciones del fabricante. Brevemente, la membrana fue lavada con agua destilada durante aproximadamente 4 horas. A continuación, se lavó con sulfuro sódico a $80^{\circ} \mathrm{C}$ durante 2 minutos, seguidamente se atemperó la membrana con agua destilada calentada a $60^{\circ} \mathrm{C}$ y después se acidificó la membrana con ácido sulfúrico $0,2 \mathrm{M}$. Por último se terminó con un aclarado de la membrana con agua ultrapura durante 15 minutos. Se preparó una disolución de albúmina al 10\% (p/v) en solución de Elliot. Se ajustó el pH a 7,37 y se dializó durante 24 horas, con tres cambios de la solución de Elliot. Después de la diálisis, se filtró la albúmina y se almacenó en alícuotas a $-20^{\circ} \mathrm{C}$.

\subsubsection{Preparación y purificación de la alfa-fetoproteína}

\subsubsection{Material de partida}

La alfa-fetoproteína (AFP) fue obtenida a partir del medio condicionado de células de línea de hepatoma de rata McA-RH 7777 (ver sección 3.2.1.3).

Tras el tercer pase, y cuando las células se encuentraban aproximadamente al $75 \%$ de su confluencia y creciendo en frascos de cultivo de $125 \mathrm{~cm}^{2}$, se cambió el medio de cultivo a DMEM sin suero durante 12 horas. A continuación, este medio se desechó y se añadió medio fresco sin suero.

Transcurridas 24 horas, se recogió este medio y se cambió por medio fresco 
sin suero. El medio recogido se centrifugó durante 5 minutos a 500 g para retirar las células en suspensión. El sobrenadante se filtró a través de un filtro de 0,2 $\mu \mathrm{m}$ de tamaño de poro y se congeló a $-80^{\circ} \mathrm{C}$. Este proceso se repite entre 3 y 4 veces.

Después se lavaron las células con PBS estéril a $37^{\circ} \mathrm{C}$ y se resembraron, tal y como queda detallado en la sección 3.2.1.3

Este proceso de recogida y almacenamiento de los medios se repitió hasta la obtención de un volumen total de 2 litros.

\subsubsection{Proceso de purificación}

Se descongelaron los medios durante 24 horas a $4{ }^{\circ} \mathrm{C}$. Una vez descongelados, los medios fueron mezclados y filtrados a través de un filtro de 0,2 $\mu \mathrm{m}$ de tamaño de poro.

\subsection{Concentración inicial}

Para la concentración inicial de los medios de hepatoma se empleó un dispositivo Pellicon XL (Millipore), que posee un tamaño de exclusión de 50 kDa, y a través del cual se hizo pasar el medio con una bomba peristáltica de flujo variable.

El sistema posee un recipiente de "suministro", otro para el "retenido" y otro para el "permeado", cada uno con sus tubos correspondientes. Para utilizar el sistema, en primer lugar se lava con agua ultrapura para eliminar todos los restos de los productos que se usan para la conservación del filtro (glicerina, azida sódica, sosa, etc). A continuación, el dispositivo se equilibró con DMEM sin suero. Por último, se procedió a concentrar el medio condicionado, para lo cual el tubo para el retenido se colocó junto al tubo de suministro en el recipiente que contienía el medio. El dispositivo permite el paso por el filtro de las moléculas inferiores a $50 \mathrm{kDa}$, recirculando al recipiente de "suministro" las que quedan retenidas. La velocidad de la concentración fue de $30-50 \mathrm{~mL} / \mathrm{min}$. El recipiente de suministro se mantuvo a $4{ }^{\circ} \mathrm{C}$ y en agitación. Se continuó el proceso hasta conseguir un volumen de entre 20 y $50 \mathrm{~mL}$.

Cuando terminó el proceso, se recuperaron los volúmenes muertos que que- 
daron en los tubos. Posteriormente el sistema Pellicon y los tubos se lavaron con $\mathrm{NaOH} 0,5 \mathrm{~N}$ caliente, tal y como se describe en las instrucciones. Posteriormente se lavó con agua ultrapura y se almacenó con $\mathrm{NaOH} 0,1 \mathrm{~N}$ a $4{ }^{\circ} \mathrm{C}$, en horizontal.

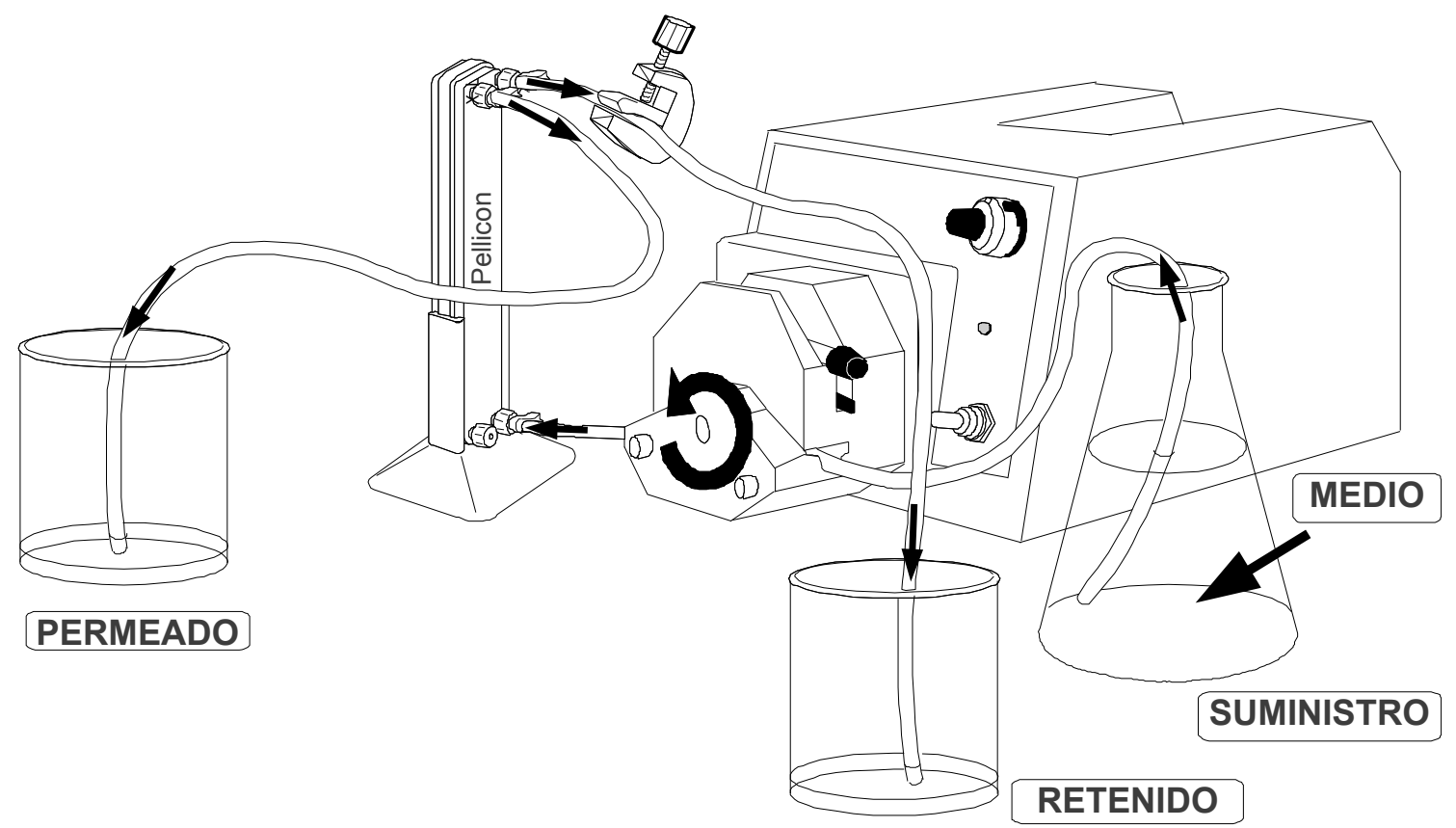

Esquema 15.- Dispositivo de concentración del medio de hepatoma. Sistema Pellicon acoplado a una bomba peristáltica utilizados para la concentración inicial del medio de hepatoma durante el proceso de purificación de la AFP.

\subsection{Retirada de la albúmina del medio}

Para la retirada de la albúmina presente en la fracción se emplearon unas columnas Bio-Scale Mini Affi-Gel Blue de $5 \mathrm{~mL}$ de (Bio-Rad) que atrapan albúmina por afinidad al colorante Azul de Cibracron F3GA. Estas columnas fueron acopladas a una bomba para jeringa de flujo regulable (New Era Pump Systems Inc.). Para la retirada de albúmina se conectaron dos columnas seguidas, a fin de permitir la entrada de un volumen mayor.

Los tampones utilizados en este paso fueron los siguientes:

Tampón de aplicación:

A) $\mathrm{Na}_{2} \mathrm{HPO} 40,02 \mathrm{M}, \mathrm{pH} 7,1$

Tampones de elución:

B) $\mathrm{NaCl}$ 1,4 M, Tris- $\mathrm{HCl} 0,02 \mathrm{M}$, pH 8,0. 
C) $\mathrm{NaCl} 1,4 \mathrm{M}$, Na2HPO4 0,02 M, pH 7,1.

Tampones de regeneración:

D) $\mathrm{NaCl} 1,4 \mathrm{M}$, ácido acético $0,1 \mathrm{M}, \mathrm{pH} 3,40 \% \mathrm{v} / \mathrm{v}$ isopropanol.

E) Guanidina-HCl 2,0 en tampón de aplicación.

Todos los tampones han de ser desgasificados antes de su uso en un baño de sonicación.

Previamente al proceso de retirada de albúmina, el medio concentrado obtenido como se indica en el apartado anterior ha de ser equilibrado en el tampón de aplicación A). Para ello, el medio fue dializado durante 12 horas a $4{ }^{\circ} \mathrm{C}$ con el tampón de aplicación A). Para la diálisis se utilizó una tripa de diálisis de celulosa (Sigma) idéntica a la utilizada en el proceso de preparación de albúmina libre de ácidos grasos. Tras esta diálisis aparece un precipitado blanquecino y de aspecto viscoso que se retiró centrifugando a 2.000 x g durante 5 minutos, a $4{ }^{\circ} \mathrm{C}$. Los análisis posteriores demostraron que este precipitado arrastró parte de la AFP presente en el medio pero que esta cantidad era despreciable respecto de la que permaneció en el sobrenadante.

A continuación se preparó el dispositivo para la retirada de albúmina. En primer lugar la columna tiene que ser equilibrada con el tampón de aplicación:

1. La columna se lavó con el tampón de regeneración D) a un flujo de $1 \mathrm{~mL} / \mathrm{min}$ durante 10 minutos.

2. Se lavó con tampón de elución B) a un flujo de 2,0 $\mathrm{mL} / \mathrm{min}$ durante 10 minutos.

3. Se lavó con tampón de aplicación A) a un flujo de 2,0 mL/min durante 10 minutos.

4. La columna fue equilibrada con tampón de aplicación A) a un flujo de 1,0 $\mathrm{mL} / \mathrm{min}$ durante 10 minutos.

A continuación se procedió a la retirada de la albúmina propiamente dicha:

5. La muestra se aplicó a un flujo de $1 \mathrm{~mL} / \mathrm{min}$ (no aplicar más volumen que el volumen máximo de la columna). Previamente, la muestra había sido filtrada $(0,2$ $\mu \mathrm{m})$. 
6. La columna se lavó con 10-15 $\mathrm{mL}$ de tampón de aplicación A) y esa fracción fue recogida, ya que era la que contenía la AFP.

7. La albúmina que ha quedado atrapada en la columna fue retirada. Para ello se aplicó 10-20 mL de tampón de elución C).

En el caso de volver a usar la columna, primero ha de ser regenerada. Los pasos son los siguientes:

8. El flujo se ajustó a 2,0 mL/ min.

9. La columna se lavó con $10 \mathrm{~mL}$ de tampón de elución C).

10. Se lavó con $10 \mathrm{~mL}$ de tampón de regeneración E).

11. Se lavó con $20 \mathrm{~mL}$ de tampón de aplicación A).

12. El flujo se redujo nuevamente a $1,0 \mathrm{~mL} / \mathrm{min}$ para continuar con la muestra siguiente.

Las columnas pueden ser conservadas a $4{ }^{\circ} \mathrm{C}$ en tampón de aplicación con azida sódica al $0,05 \%$. Para ello repetimos los dos primeros pasos de la regeneración anterior (8 y 9) y se lavó con el tampón de almacenaje.

\subsection{Segunda concentración de la alfa-fetoproteína}

Para esta última concentración se usaron filtros de centrífuga Amicon Ultra-15 Ultracel 50K (Millipore), con un tamaño de exclusión molecular de 50 kDa.

En primer lugar, el filtro se limpió centrifugando a través de el $15 \mathrm{~mL}$ de $\mathrm{NaOH}$ $0,1 \mathrm{~N}$. Posteriormente, se centrifugó con agua destilada y, por último, se equilibró el filtro centrifugando con tampón Elliot.

Seguidamente se tomó el medio que posee AFP obtenido tal y como se describe en el apartado anterior, libre de albúmina, y se filtró $(0,2 \mu \mathrm{m})$. Posteriormente, ese medio se centrifugó a través del filtro a $2.000 \times g$ durante 15-20 minutos y el volumen que quedó retenido se recogió con una micropipeta. Este proceso se repitió hasta la obtención del volumen y el factor de concentración deseado.

\subsection{Diálisis final de la alfa-fetoproteína}

Tras seguir los pasos descritos en el apartado anterior, se obtuvo una solución 
que contenía la AFP; sin embargo para poder ser utilizada en estudios in vitro es necesario que la proteína se encuentre en un medio fisiológico. Para ello se dializó frente a un tampón Elliot de igual composición al utilizado en el proceso de preparación de la albúmina libre de ácidos grasos (apartado 3.2.3). La diálisis se realizó, durante 24 horas, utilizando un casete de microdiálisis (Thermo Scientific) de tamaño de exclusión molecular de 20 kDa, en agitación con tres renovaciones del tampón.

Finalmente, la AFP fue esterilizada con un filtro de $0,20 \mu \mathrm{m}$, se prepararon alícuotas y el stock se conservó a $-80^{\circ} \mathrm{C}$ (ver esquema 16 en la página siguiente para un esquema resumido del proceso de purificación de la AFP).

\subsubsection{Tratamientos empleados en los cultivos}

Las concentraciones de los tratamientos están expresadas como porcentajes de $p / v$.

\subsubsection{Tratamientos en neuronas}

Para determinar el efecto de la AFP sobre la viabilidad neuronal, las neuronas fueron cultivadas durante 72 horas en medio definido, en ausencia o en presencia de concentraciones crecientes de AFP $(0,00005 \%$ hasta $0,02 \%)$.

Con el fin de determinar la especificidad del efecto de la AFP sobre los cultivos neuronales, las neuronas se incubaron durante 72 horas en medio definido suplementado con alfa-1-antitripsina, T-kininógeno y disulfuro isomerasa (en concentraciones equivalentes a las presentes en el purificado del lote 1 en relación a la AFP). Estas proteínas representaban el $15,75 \%$, el $4,06 \%$ y el $2,53 \%$ respectivamente y fueron añadidas en esas proporciones al cultivo primario de neuronas. Por cada $100 \mu \mathrm{g}$ de AFP, se añadieron 15,75 $\mu \mathrm{g}$ de $\alpha$-1-antitripsina, 4,06 $\mu \mathrm{g}$ de Tkininógeno y $2,53 \mu \mathrm{g}$ de disulfuro isomerasa, por mililitro de medio. De la misma manera, se incubaron las neuronas durante 72 horas en medio definido suplementado con AFP 0,005\%, AFP 0,005\% desnaturalizada $\left(100{ }^{\circ} \mathrm{C}\right.$ durante 10 minutos) o con albúmina de rata $0,005 \%$, obtenida a partir del mismo medio de hepatoma del que se obtuvo la AFP. 


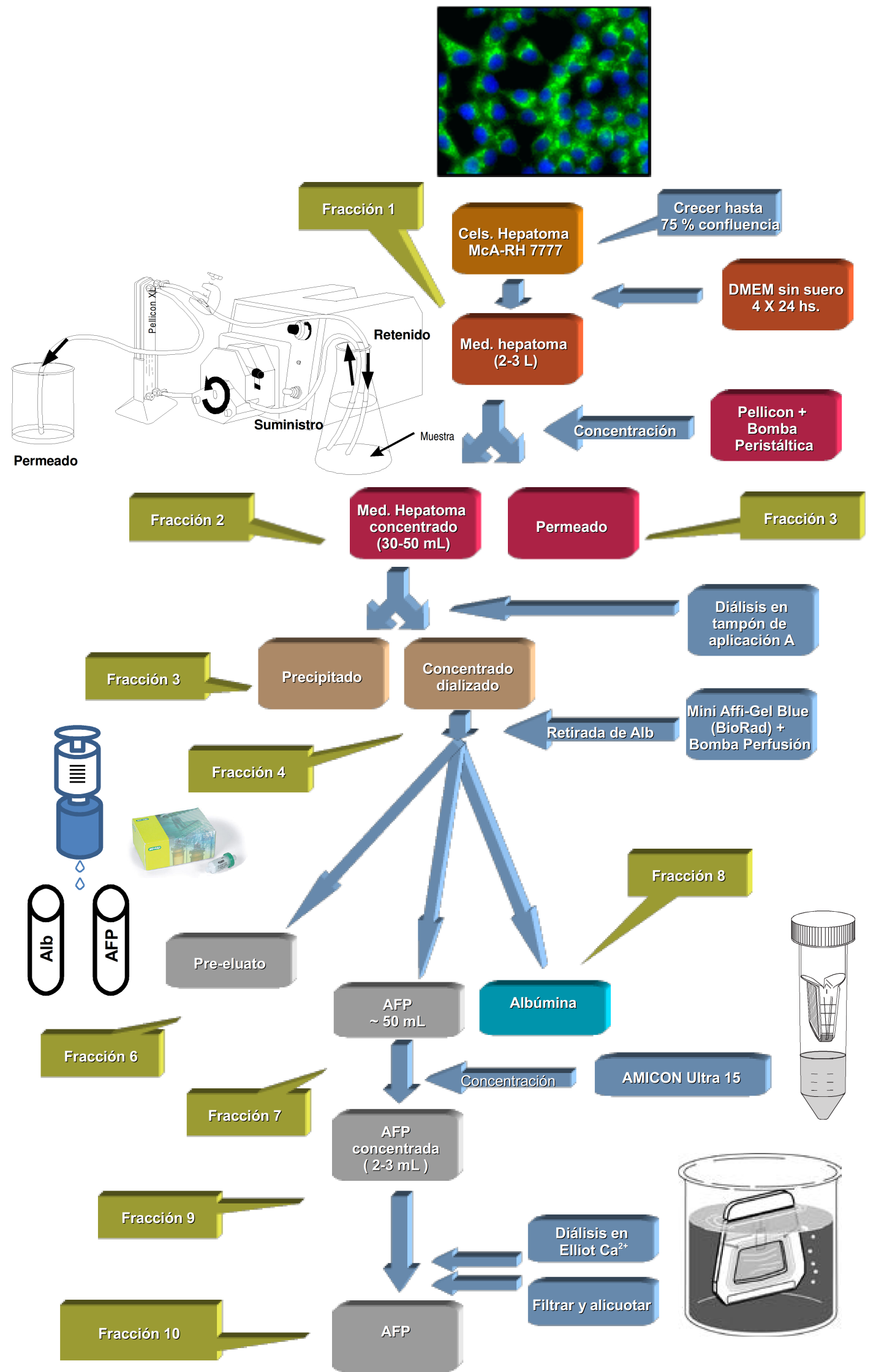

Esquema 16.- Diagrama del proceso de purificación de la AFP 
Con el objeto de evaluar el efecto de la AFP sobre la proliferación mediante el ensayo de BrdU, las neuronas en cultivo se incubaron en medio definido en presencia o ausencia de AFP al 0,005\%, al 0,000625\% y al 0,00005\% durante 24 horas.

Para determinar el efecto de la AFP sobre la viabilidad y la diferenciación neuronal en presencia de albúmina y ácido oleico, las neuronas en cultivo primario fueron cultivadas durante 72 horas en medio definido suplementado con albúmina al $2 \%$, albúmina al $2 \%$ con ácido oleico $50 \mu \mathrm{M}$ (solución stock: $100 \mathrm{mM}$ en albúmina al $10 \%$ ) o con albúmina al $2 \%$ con ácido oleico $50 \mu \mathrm{M}$ y AFP $0,025 \%$.

\subsubsection{Tratamientos en astrocitos}

Los astrocitos fueron cultivados en DMEM con FBS; a los 14 días in vitro (DIV) se retiró el medio y se añadió DMEM sin FBS durante 12 horas. Transcurrido ese tiempo las células se incubaron durante 72 horas en DMEM, en ausencia o en presencia de concentraciones crecientes de AFP desde $0,00005 \%$ hasta $0,1 \%$.

\subsubsection{Tratamientos en cultivos organotípicos de rodajas de cerebro}

Las rodajas fueron cultivadas durante 48 horas en medio Neurobasal (B27 20 $\mu \mathrm{L} / \mathrm{mL}$, glucosa al $50 \%$ y penicilina $\mathrm{G} 50 \mathrm{U} / \mathrm{mL}$, estreptomicina $37,5 \mathrm{U} / \mathrm{mL}$ en medio Neurobasal) suplementado con albúmina al $2 \%$, albúmina al $2 \%$ con ácido oleico $50 \mu \mathrm{M}$ (solución stock: $100 \mathrm{mM}$ en albúmina al 10\%) o con albúmina al $2 \%$ con ácido oleico $50 \mu \mathrm{M}$ y AFP 0,025\%.

\subsubsection{Determinación de la expresión de proteínas mediante análisis de transferencia tipo Western}

1) Extracción de las proteínas

Las proteínas procedentes del tejido en cultivo o del tejido cerebral se extrajeron con una solución de extracción de proteínas compuesta por: Tris- $\mathrm{HCl} 50 \mathrm{mM}$ (pH 8), NaCl 150 mM, Triton X-100 1\%, azida sódica 0,02\%, EDTA 2 mM, EGTA 2 $\mathrm{mM}$, PMSF $1 \mathrm{mM}$ y un cóctel de inhibidores de proteasas. Los lisados se hirvieron 


\section{Alejandro García García}

durante 5 minutos y se sonicaron durante 5 minutos. Por último, se centrifugaron a $11.000 \times \mathrm{g}$ durante 10 minutos a $4^{\circ} \mathrm{C}$ y se almacenaron a $-80^{\circ} \mathrm{C}$.

2) Cuantificación de las proteínas

Las proteínas se cuantificaron siguiendo diferentes métodos. La cuantificación mediante el método de Bradford (Bradford 1976) se empleó para las muestras procedentes de tejido cerebral. Brevemente, una alícuota de la muestra de proteínas se diluyó 1.000 veces en agua ultrapura. De esa dilución se tomó un volumen de $800 \mu \mathrm{L}$ y se añadieron $200 \mu \mathrm{L}$ de reactivo de Bradford (Bio-Rad). Se agitó la mezcla en el vórtex y se dejó a temperatura ambiente durante 10 minutos. A continuación, se procedió a medir la absorbancia a una longitud de onda de $595 \mathrm{~nm}$. La concentración de proteínas se determinó extrapolando en una recta patrón, realizada simultáneamente con disoluciones entre 1 y $25 \mu \mathrm{g} / \mathrm{mL}$ de albúmina sérica bovina.

Las muestras procedentes del proceso de purificación de la AFP fueron cuantificadas con un dispositivo Nanophotomer, midiendo la absorbancia a $280 \mathrm{~nm}$ con corrección de fondo a $320 \mathrm{~nm}$.

Las muestras procedentes de los cultivos celulares y organotípicos fueron cuantificadas mediante el dispositivo Qubit, siguiendo las instrucciones proporcionadas por el fabricante (Invitrogen).

3) Preparación de los geles

Las proteínas se separaron en geles de acrilamida. Para las muestras procedentes de extractos de cerebro y de la purificación de la AFP, se prepararon geles de poliacrilamida, de 8 y $16 \mathrm{~mm}$ de longitud respectivamente y de un grosor de $1,5 \mathrm{~mm}$, compuestos por un gel de separación $(10 \%$ de poliacrilamida para todas las proteínas analizadas) y por un gel de concentración ( $4 \%$ de poliacrilamida). El gel de separación estaba compuesto por Tris- $\mathrm{HCl} 0,375 \mathrm{M}(\mathrm{pH} 8,8)$, acrilamida/Bis acrilamida $10 \%(p / v)$, SDS $0,1 \%(p / v)$, persulfato de amonio (AMPS) $0,05 \%(p / v)$ y N,N,N',N'-tetrametilendiamino (TEMED) 0,05\% (p/v). El gel de concentración estaba compuesto por Tris- $\mathrm{HCl} 0,125 \mathrm{M}(\mathrm{pH} \mathrm{6,8)}$, acrilamida/Bis acrilamida 4\% (p/v), SDS $0,1 \%(p / v)$, AMPS $0,05 \%(p / v)$ y TEMED $0,05 \%(p / v)$. 
Para las muestras procedentes del cultivo de neuronas y de organotípicos se emplearon geles de gradiente de acrilamida $4-12 \%$ de Invitrogen.

4) Preparación de las muestras para la electroforesis y electroforesis de las proteínas

Las muestras procedentes de homogenados de cerebro fueron resuspendidas en un volumen igual de tampón de carga según Laemmli (Laemmli 1970) (Tris-H$\mathrm{Cl}$ pH $6.840 \mathrm{mM}$, SDS al 2\% (p/v), glicerol al 20\% (p/v), azul de bromofenol $0,01 \%$ y DTT $3 \mathrm{mM}$ ). Las muestras procedentes de la purificación de la AFP se mezclaron con un tampón de carga cuatro veces mas concentrado modificado de Laemmli, compuesto por Tris-HCl pH 6.8 183,3 mM, SDS al 3,7\%, glicerol al 46\% $(\mathrm{p} / \mathrm{v})$, azul de bromo-fenol al 0,042\% y 2-mercaptoetanol $594 \mathrm{mM}$. Se hirvió la mezcla durante 5 minutos y, tras realizar una rápida centrifugación, se mantuvieron en hielo.

Por último, las muestras procedentes de los cultivos de neuronas y organotípicos se mezclaron con el tampón de carga comercial específico para los geles del sistema Novex. Estas muestras se calentaron a $70^{\circ} \mathrm{C}$ durante 10 minutos.

Electroforesis de las proteínas

Las muestras se aplicaron en los distintos pocillos del gel, incluyendo un marcador de masas moleculares $(250,150,100,75,50,37,25,20,15$ y 10 kDa). En todas las electroforesis SDS-PAGE se utilizaron $30 \mu \mathrm{g}$ de proteína total salvo en el caso de las proteínas procedentes del proceso de purificación de la AFP, en el que se aplicaron $2 \mu \mathrm{g}$.

El tampón utilizado para la electroforesis fue Tris $25 \mathrm{mM}$ y glicina $0,19 \mathrm{M}(\mathrm{pH}$ $8,3)$, con SDS $0,1 \%(p / v)$ para los geles manufacturados y un tampón MOPS (Invitrogen) para los geles de gradiente comerciales.

Las electroforesis se realizaron a temperatura ambiente, a voltaje constante (en torno a $110 \mathrm{~V}$ ) y durante $2-3$ horas.

5) Electrotransferencia

Las proteínas separadas procedentes de los homogenados de cerebro, se transfirieron del gel de poliacrilamida a una membrana de nitrocelulosa de 0,45 


\section{Alejandro García García}

um de tamaño de poro. El tampón de transferencia tenía la siguiente composición: Tris $25 \mathrm{mM}$ y glicina $0,19 \mathrm{M}(\mathrm{pH} 8,6)$, con SDS $0,1 \%$ y metanol $10 \%$. Para la electrotransferencia se aplicó un amperaje constante de $400 \mathrm{~mA}$, durante 12 horas a 4 ${ }^{\circ} \mathrm{C}$, de manera que las proteínas van pasando a la membrana atraídas por la carga eléctrica positiva, quedando inmovilizadas en la misma posición que ocupaban en el gel.

Las proteínas separadas procedentes del proceso de purificación de la AFP y de los cultivos de neuronas y organotípicos, se transfirieron a una membrana de nitrocelulosa mediante un proceso de electrotransferencia semi-seca utilizando el dispositivo iBlot de Invitrogen. Brevemente: los geles se lavaron y equilibraron en tampón de equilibrado (10\% de metanol, 1:1.000 antioxidante NuPAGE® en "NuPAGE $®$ Transfer Buffer $2 x "$ ), durante 10 minutos $y$, posteriormente, se transfirieron durante 10 minutos, aplicando un voltaje constante de $20 \mathrm{~V}$. Asimismo se utilizó este dispositivo para la transferencia de las proteínas separadas mediante electroforesis bidimensional (ver sección 3.2.6.1).

6) Visualización de las proteínas y bloqueo de la membrana

La presencia de proteínas en la membrana se detectó mediante tinción con Rojo Ponceau al 10\% (v/v). A continuación, la membrana se bloqueó durante 1 hora a temperatura ambiente, con una solución de leche desnatada en polvo al $7 \%(\mathrm{p} / \mathrm{v})$ en TTBS (Tris-base 20mM, NaCl 500mM, pH 7,5, Tween 20 0,1\% (v/v)) o, en el caso de la detección de AFP y albúmina, con una solución de caseína al 10\% ( $\mathrm{p} / \mathrm{v}$ ) en Tris-HCl $500 \mathrm{mM} \mathrm{pH} \mathrm{7,5}$ con azida sódica 0,02\% como conservante.

7) Inmunodetección

Para detectar las proteínas en la membrana, se incubó con el anticuerpo primario contra la proteína de interés, durante 12 horas a $4{ }^{\circ} \mathrm{C}$, excepto para la detección de GAPDH o de tubulina, que se realizó durante 2 horas a temperatura ambiente. Los anticuerpos primarios utilizados fueron los siguientes: anticuerpo monoclonal de ratón contra GAP-43 (1:500), anticuerpo monoclonal de ratón contra MAP-2 (1:500), anticuerpo policlonal de conejo contra la AFP humana (1:2.000), anticuerpo policlonal de conejo contra la albúmina de rata (1:2.000), anticuerpo monoclonal de ratón contra la GAPDH (1:2.000) y anticuerpo monoclonal 
de ratón contra la tubulina (1:2.000). Los anticuerpos primarios se prepararon en una solución compuesta por FBS 10\% (v/v), azida sódica 0,02\% (p/v) y lisina 0,1 $\mathrm{M}$ denominada "solución de anticuerpos", exceptuando los anticuerpos policlonales de conejo contra la AFP y la albúmina de rata, que se prepararon en una solución de TTBS y azida al 0,02\% (p/v).

A continuación, se incubó con anticuerpo secundario contra inmunoglobulina de ratón (1:5.000) o de conejo (1:10.000), conjugado con peroxidasa en TTBS, durante 1 hora a temperatura ambiente. En este punto se forma un complejo proteína-anticuerpo primario-anticuerpo secundario.

La inmunodetección se realizó mediante quimioluminiscencia. En este sistema, el sustrato quimioluminiscente luminol añadido a las membranas es oxidado por la peroxidasa conjugada con el anticuerpo secundario, en presencia del sustrato peróxido de hidrógeno $\left(\mathrm{H}_{2} \mathrm{O}_{2}\right)$, en condiciones alcalinas. Inmediatamente después de la oxidación, el luminol excitado decae a su estado fundamental por emisión de luz. La luz emitida es detectada por exposición a una película de autorradiografía, siendo esta luz proporcional a la cantidad de proteína presente en la membrana, en condiciones de exposición subsaturante. Finalmente, se cuantificaron las bandas en las películas de autorradiografía mediante el programa ImageJ para Linux (http://rsbweb.nih.gov/ij/index.html), basándonos en el método descrito por Luke Miller (http://lukemiller.org/).

\subsubsection{Análisis proteómico de la alfa-fetoproteína.}

El resultado de la purificación de la alfa-fetoproteína fue analizado mediante electroforesis bidimensional y espectrometría de masas MALDI-TOF, en la Unidad de Proteómica del Centro de Investigación del Cáncer de la Universidad de Salamanca.

En primer lugar, se resolvieron entre 3,07 y 0,82 $\mu \mathrm{g}$ de proteína purificada en una tira de $7 \mathrm{~cm}$ con un gradiente de $\mathrm{pH}$ de 3 a 10. Seguidamente, se separaron las proteínas en la segunda dimensión mediante electroforesis SDS-PAGE en un gel de $8,5 \%$ de acrilamida. El resultado de la electroforesis bidimensional fue sometido a tinción de plata, obteniendo un patrón de puntos correspondientes a las 


\section{Alejandro García García}

proteínas y restos peptídicos presentes en el purificado. Esos puntos fueron recortados y sometidos a digestión en gel con tripsina. El análisis de los fragmentos peptídicos obtenidos se realizó mediante espectrometría de masas tipo MALDITOF y búsqueda en la base de datos SwissProt o MSDB no redundante. De este análisis se obtuvo un resultado (Score) correspondiente con el -10* $\log (P)$, siendo $\mathrm{P}$ la probabilidad de que el resultado obtenido sea al azar. Un resultado es significativo $(p<0,05)$ cuando el valor del Score supera 66 .

Asimismo se realizó en paralelo otra electroforesis. Seguidamente se realizó la transferencia de las proteínas a una membrana de nitrocelulosa utilizando el sistema iBlot de transferencia seca y posteriormente se incubó la membrana con el anticuerpo primario policlonal contra la AFP tal y como se describe en la sección anterior. Por último esa misma membrana fue sometida a un "stripping" con una solución de "stripping" (SDS al 2\%, Tris $\mathrm{HCl} 62 \mathrm{mM} \mathrm{pH} 6.8$ y $\beta$-mercaptoetanol 0,7\% $\mathrm{v} / \mathrm{v}$ ) a $50^{\circ} \mathrm{C}$ durante 75 minutos. Seguidamente se lavó la membrana en abundante TTBS y se bloqueó en caseína al $10 \%$ para posteriormente incubar la membrana con el anticuerpo primario policlonal contra la albúmina sérica de rata tal y como se describe en la sección anterior.

\subsubsection{Análisis de los ácidos grasos}

\subsubsection{Extracción de los ácidos grasos}

Para la determinación de ácidos grasos por HPLC se siguió el método de Bligh y Dyer (Bligh y Dyer 1959) con algunas modificaciones, tal y como se ha descrito anteriormente (Polo-Hernández y col. 2010).

Tras la decapitación de los animales a diferentes días de gestación se extrajeron los cerebros y se realizaron 3 lavados, de 10 minutos cada uno, en PBS a 4 ${ }^{\circ} \mathrm{C}$ durante 1 hora. A continuación los cerebros se congelaron con nitrógeno líquido y se almacenaron a $-80^{\circ} \mathrm{C}$ hasta su procesamiento.

Para la determinación de ácidos grasos libres, cada cerebro, por separado se homogeneizó en $2 \mathrm{~mL}$ de PBS, exceptuando los cerebros E14,5 y E15,5 que fueron homogeneizados en grupos de 3. Posteriormente, se adicionó al homogenado 
un antioxidante, el 2,6-di-ter-butil-4-metilfenol (BHT), a una concentración de $0,125 \mathrm{mg} / \mathrm{mL}$, y como estándar interno se empleó ácido margárico ( $\mathrm{C} 17: 0$, ácido heptadecanoico), un ácido graso sintético no presente en los tejidos orgánicos, a una concentración de $125 \mu \mathrm{M}$.

Para la extracción de ácidos grasos se añadieron al homogenado $2 \mathrm{~mL}$ de metanol y $1 \mathrm{~mL}$ de cloroformo y se agitaron hasta conseguir una sola fase. Seguidamente, se añadieron $1 \mathrm{~mL}$ de cloroformo y $2 \mathrm{~mL}$ de PBS $1 \mathrm{mM}$, se agitaron vigorosamente y se centrifugaron a 2.000 x g durante 10 minutos. Como resultado de la centrifugación la mezcla se separó en dos fases. La fase que había decantado, o fase orgánica, fue transferida entonces a un nuevo tubo y fue evaporada bajo corriente de nitrógeno $\left(\mathrm{N}_{2}\right)$.

Posteriormente, se añadieron al residuo resultante de la evaporación de la fase orgánica $2 \mathrm{~mL}$ de n-hexano y $1 \mathrm{~mL}$ de $\mathrm{H}_{2} \mathrm{O}$. Se agitó entonces vigorosamente durante 2 minutos y se centrifugó a 2.000 x g durante 10 minutos. La fase orgánica queda en esta ocasión en la parte superior del tubo. Esta se retiró y fue secada nuevamente bajo corriente de $\mathrm{N}_{2}$.

\subsubsection{Derivatización de los ácidos grasos.}

El método de separación e identificación de ácidos grasos mediante HPLC está basado en el descrito por Puttmann (Puttmann y col. 1993). Consiste en la separación de los ésteres de ácidos grasos derivatizados después de la reacción con 4-bromofenacil bromuro (PBPB).

Para la derivatización de los ácidos grasos, se redisolvió el extracto seco obtenido tras la extracción de los ácidos grasos en $500 \mu \mathrm{L}$ de acetonitrilo y se añadieron $6 \mu \mathrm{L}$ de solución de derivatización (69,5 mg de PBPB, 6,6 mg de 18-crown-6, $0,2 \mathrm{~g}$ de $\mathrm{KHCO}_{3}$, disueltos en $5 \mathrm{~mL}$ acetonitrilo) preparada ese mismo día. Se mantuvo la mezcla a $70{ }^{\circ} \mathrm{C}$ en un bloque térmico para el calentamiento de tubos en seco durante 45 minutos. A continuación se centrifugó la mezcla a 2.000 x g durante 5 minutos, el sobrenadante se transfirió a un nuevo tubo y se evaporó en corriente de $\mathrm{N}_{2}$. 


\subsubsection{Método cromatográfico}

Una vez derivatizado, el extracto se redisolvió en $100 \mu \mathrm{L}$ de acetonitrilo y se cromatografió durante 40 minutos por HPLC, en una columna de sílica en fase reversa $\mathrm{C} 18$, mantenida a $4{ }^{\circ} \mathrm{C}$, utilizando como fase móvil un gradiente de elución de $85 \%$ de acetonitrilo/ $15 \%$ de $\mathrm{H}_{2} \mathrm{O}$ en el minuto 0 y hasta un $100 \%$ de acetonitrilo a los 15 minutos, a un flujo de $1,5 \mathrm{~mL} / \mathrm{min}$. El eluyente se hizo pasar a través de un detector UV "diode array", fijado a una longitud de onda de $252 \mathrm{~nm}$. Las señales se enviaron a un computador donde se integraron.

\subsubsection{Cuantificación de las áreas cromatográficas}

Para evitar las posibles variaciones en la eficiencia de extracción de los ácidos grasos, durante el paso por la columna cromatográfica o por el detector de UVVis, se utilizó un estándar interno no presente en el organismo, el ácido margárico (17:0). El estándar interno es un componente que no está presente en la muestra que se va a analizar y se añade a una concentración conocida. El ácido margárico eluye a diferente tiempo que el resto de los analitos pero presenta el mismo factor de extracción que éstos. La razón entre las áreas obtenidas del estándar interno y del analito nos permite estimar la concentración de este último en el cerebro inicialmente (expresada como nmol de ácido graso libre por gramo de cerebro).

\subsubsection{Obtención y preparación de tejido nervioso fijado}

\subsubsection{Fijación de las neuronas en cultivo primario}

Las células en cultivo primario fueron sometidas a tres lavados de 10 minutos en PBS. Posteriormente, las células fueron fijadas mediante paraformaldehido (PFA) al 4\% en PBS, durante 20 minutos a temperatura ambiente y, posteriormente, se lavaron en PBS para eliminar el exceso de PFA.

\subsubsection{Fijación de cerebros embrionarios y fetales.}

Los embriones de E15,5 y los fetos de E19,5 se obtuvieron por cesárea post mórtem de la madre gestante, manteniendo los animales a $4^{\circ} \mathrm{C}$. Seguidamente el tejido fue fijado mediante perfusión intracardíaca. Para ello, se preparó diariamen- 
te una solución de PFA al 4\% en PBS, atemperada previamente ya que el uso de una solución de PFA fría podría constreñir los vasos sanguíneos. A continuación, localizó el corazón y se realizó la perfusión mediante una jeringa con una aguja de 0,3 x $13 \mathrm{~mm}$ Microlance (BD) a través del ventrículo izquierdo y realizando una punción en la aurícula derecha para permitir la salida de la sangre. La solución de PFA se inyectó manualmente con mucho cuidado mediante la jeringa conjuntamente con $50 \mu \mathrm{L}$ de una solución de heparina para evitar la coagulación.

El proceso de perfusión se siguió mediante la observación de la decoloración de la cabeza y el hígado, inyectando aproximadamente $5 \mathrm{~mL}$ para los fetos de E19,5 y 1-2 mL para los embriones de E15,5.

Una vez terminado el proceso de perfusión, el cerebro se extrajo diseccionando con cuidado la cabeza. Posteriormente, los cerebros se incubaron en PFA al $4 \%$ en PBS, durante 12 horas a $4{ }^{\circ} \mathrm{C}$.

Posteriormente, se lavaron los cerebros en PBS para eliminar el exceso de fijador y se sumergieron en una solución crioprotectora de sacarosa al 30\% (p/v) en PBS, en agitación a $4{ }^{\circ} \mathrm{C}$ hasta que se hundieron. Posteriormente, se congelaron con nitrógeno líquido encastrados en O.C.T y se almacenaron a $-80^{\circ} \mathrm{C}$ hasta el momento de su procesamiento.

\subsubsection{Fijación de cultivos organotípicos}

Una vez transcurridas 48 horas de cultivo, las rodajas de cerebro procedentes de cultivos organotípicos fueron lavadas tres veces en PBS durante 10 minutos, tres veces. A continuación, se incubaron en PFA al 4\% en PBS, durante 20 minutos a temperatura ambiente. Transcurrido ese tiempo, se lavaron las rodajas en PBS para eliminar el exceso de PFA y se sumergieron en sacarosa al 30\% (p/v) hasta que se hundieron. Posteriormente las rodajas fueron encastradas en O.C.T y congeladas en $\mathrm{N}_{2}$ líquido y fueron almacenadas a $-80^{\circ} \mathrm{C}$.

\subsubsection{Obtención de los cortes histológicos}

Los bloques y las rodajas de cerebro encastrados en O.C.T se cortaron en un criostato, a una temperatura aproximada de $-22{ }^{\circ} \mathrm{C}$, en secciones de $10 \mu \mathrm{m}$ de 


\section{Alejandro García García}

grosor en planos coronales. Las secciones se recogieron sobre portaobjetos recubiertos de poli-L-lisina y se distribuyeron en series consecutivas y almacenadas a $-20^{\circ} \mathrm{C}$ hasta su procesamiento.

\subsubsection{Inmunofluorescencia}

El tejido fijado fue bloqueado durante una hora a temperatura ambiente con una solución que contenía suero de cabra al 10\% (p/v), Triton X-100 0,25\% (p/v) y azida sódica $0,02 \%(\mathrm{p} / \mathrm{v})$ como conservante. Las células en cultivo primario fijadas se incubaron con metanol frío $\left(-20^{\circ} \mathrm{C}\right)$, durante 10 minutos, para su permeabilización.

A continuación tanto el tejido fijado como las células fijadas se incubaron con el anticuerpo primario correspondiente, durante 12 horas a $4{ }^{\circ} \mathrm{C}$ en una cámara húmeda.

Los anticuerpos primarios utilizados fueron: anticuerpo monoclonal de ratón contra GAP-43 (1:500), anticuerpo policlonal de conejo contra GAP-43 (1:500), anticuerpo policlonal de conejo contra albúmina sérica bovina (BSA) (1:500) y anticuerpo policlonal de conejo contra la AFP (1:500). Los anticuerpos primarios se prepararon en PBS con suero de cabra al $1 \%$ y Triton-X-100 al 0,1\%.

A continuación, el tejido se incubó con un anticuerpo secundario conjugado con un fluorocromo, durante 1 hora a temperatura ambiente y con agitación suave. Los anticuerpos secundarios procedían de suero de cabra y fueron anticuerpo secundario conjugado con Alexa Fluor 488 o Alexa Fluor 594 contra inmunoglobulina de ratón y anticuerpo secundario conjugado con Alexa Fluor 488 o Alexa Fluor 594 contra inmunoglobulina de conejo.

Finalmente, el DNA nuclear se tiñó con DAPI $(2,5 \mu \mathrm{g} / \mathrm{mL}$ en PBS) durante $5 \mathrm{mi}-$ nutos a temperatura ambiente. En las preparaciones destinadas para su observación en microscopio confocal se añadió el compuesto To-Pro-3 (1:1.000) junto con el anticuerpo secundario. Las preparaciones se montaron con el medio SlowFade Gold antifade reagent. Entre cada paso se realizaron 3 lavados con PBS de 10 min cada uno, a temperatura ambiente.

Las preparaciones fueron observadas con un microscopio confocal o con un 
microscopio de fluorescencia invertido conectado a una videocámara digital, obteniéndose imágenes confocales o de fluorescencia.

\subsubsection{Determinación inmunocitoquímica de la incorporación de BrdU}

La incorporación de BrdU se determinó mediante inmunocitoquímica, según el método descrito por Tabernero y colaboradores (Tabernero, Jimenez, y col. 2001), con algunas modificaciones.

Las neuronas en cultivo primario se incubaron con BrdU $10 \mu \mathrm{M}$, un análogo de la timidina que se incorpora selectivamente al DNA en la fase $S$ del ciclo celular, a tiempo 0 . Transcurridas 24 horas el medio de cultivo se retiró y las células se lavaron 2 veces con PBS. A continuación, se fijaron con PFA al 4\% en PBS durante 20 minutos. Seguidamente, se lavó el exceso de PFA mediante tres lavados de 10 minutos en PBS y se realizó una incubación con $\mathrm{HCl} 2 \mathrm{M}$ durante 20 minutos. $\mathrm{A}$ continuación, las células se sometieron a sucesivas incubaciones durante 1 hora con la solución de anticuerpos descrita en el apartado 3.2.5.

Seguidamente, las células se incubaron con el anticuerpo primario policlonal de rata contra la BrdU (1:400) durante 12 horas. A continuación, se incubaron con el anticuerpo secundario contra inmunoglobulina de rata conjugado con Cy3 (1:200), durante 2 horas. Ambos anticuerpos se diluyeron en la solución de anticuerpos a la que se añadió Triton X-100 a una concentración de 0,1\% (v/v).

Por ultimo, los núcleos se tiñeron con DAPI $(1,25 \mu \mathrm{g} / \mathrm{mL})$ mediante una incubación de 5 minutos. Se lavaron nuevamente con PBS y se montaron las placas con el medio "SlowFade Gold antifade reagent". Una vez realizada la tinción, las placas se observaron con un microscopio invertido de fluorescencia con los filtros adecuados, tomándose varias imágenes al azar correspondientes a diferentes campos de cada tratamiento utilizando el objetivo de 20x. Finalmente, se contaron, el número de células marcadas con BrdU y se compararó con el número total de células (identificadas mediante DAPI) en tres campos de al menos tres experimentos diferentes. 


\subsubsection{Estudio de la viabilidad celular}

\subsubsection{Determinación de la viabilidad celular mediante ensayo colorimétrico con MTT}

El método del MTT (3-(4,5-dimetiltiazol-2-il)-2,5-difenil-tetrazolio) fue propuesto por Mosmann (Mosmann 1983) como un método para evaluar los efectos citotóxicos de una sustancia, así como para realizar estudios de proliferación celular. El MTT es una sal de tetrazolio de color amarillo, que es convertida por las deshidrogenasas mitocondriales de las células vivas en cristales de formazán de color azul oscuro-violeta. Después de la solubilización de dichos cristales en DMSO, se obtiene un medio de color violeta, cuya mayor o menor absorbancia a $570 \mathrm{~nm}$ se relaciona directamente con el número de células vivas presentes en el cultivo.

Para determinar la viabilidad celular mediante el ensayo colorimétrico con MTT, se retiró el medio de cultivo y se incubaron las neuronas con $300 \mu \mathrm{L}$ de PBS que contenía MTT $(0,5 \mathrm{mg} / \mathrm{mL})$, o $150 \mu \mathrm{L}$ en el caso de los astrocitos, durante 75 minutos, en oscuridad, a $37^{\circ} \mathrm{C}$, en un incubador de $\mathrm{CO}_{2}$. Posteriormente, se aspiró el medio, se añadieron $500 \mu \mathrm{L}$ de DMSO y se incubaron las células en agitación y en oscuridad durante 10 minutos. Finalmente se midió la absorbancia a 570 $\mathrm{nm}$.

\subsubsection{Determinación de la apoptosis tardía mediante la tinción tipo TUNEL (Terminal transferase-mediated dUTP Nick End Labelling)}

La técnica de TUNEL en neuronas para la detección de células que presentan fragmentos rotos de DNA y, que en consecuencia, se encuentran en apoptosis, se realizó tal y como se ha descrito anteriormente por Baltanás y colaboradores (Baltanás y col. 2009). Este procedimiento se aplicó en neuronas fijadas con paraformaldehido al $4 \%$ en PBS, durante 20 minutos. Seguidamente las células se lavaron con PBS tres veces durante 10 minutos cada una. Posteriormente, las células se incubaron en tampón TUNEL (Tris $30 \mathrm{mM} \mathrm{pH} \mathrm{7,2,} \mathrm{cacodilato} \mathrm{de} \mathrm{sodio} 140 \mathrm{mM}$, cloruro de cobalto $1 \mathrm{mM}$ y Triton X-100 0,3\%). A continuación, se incubaron las 
células con transferasa terminal $(2 \mu \mathrm{L} / \mathrm{mL})$ y dUTP biotilinados $(1 \mu \mathrm{L} / \mathrm{mL}$; Roche), durante 2 horas a $37^{\circ} \mathrm{C}$, en tampón TUNEL. Quince minutos antes de terminar esta incubación, se añadió a las células ioduro de propidio (I.P, 1:2.000) para la contratinción. La reacción se paró con dos lavados de 10 minutos con tampón citrato sódico (SSC) y tres lavados de 10 minutos con PBS. Después, se incubaron las células con el fluorocromo Cy2 conjugado con estreptavidina (1:500), durante 45 min a $37^{\circ} \mathrm{C}$. A continuación, se lavaron las células y se montaron las placas con el medio SlowFade Gold antifade reagent.

Finalmente, se contaron las células apoptóticas (marcadas con Cy2) y se compararon con el número de células totales (observadas mediante el I.P).

\subsubsection{Análisis estadístico}

Para el análisis estadístico de los datos utilizamos el programa SPSS 18 para Windows. Tras la recolección de los datos, éstos fueron organizados en una matriz de datos y clasificados en variables. La variable independiente es variable categórica cualitativa (tratamiento o día de desarrollo embrionario) y la variable dependiente es una cuantitativa continua (\% de viabilidad, \% de expresión relativa de una proteína, etc). Consideramos las medidas independientes (no pareadas). Una vez organizados los datos en la matriz, procedimos a la determinación de diferencias estadísticas entre las categorías o grupos. Para el análisis estadístico se utilizó el test $t$ de Student, cuando el número de grupos o categorías es igual a $2(k=2)$, o mediante el test ANOVA de un factor cuando el número de categorías a comparar es mayor de $2(\mathrm{k}>2)$. Para todas las comparaciones consideramos las diferencias significativas cuando $p<0,05$. Los resultados se presentan como medias \pm error estándar de la media de, como mínimo, tres experimentos independientes. 
Alejandro García García 
4 RESULTADOS 


\subsection{ESTUDIO DEL DESARROLLO EMBRIONARIO DEL CEREBRO DE RATA}

Estudios previos de nuestro grupo han demostrado que la albúmina induce la síntesis y liberación del factor neurotrófico ácido oleico (Velasco y col. 2003). Estos fenómenos se corresponden con los eventos del desarrollo postnatal del sistema nervioso de la rata. Con el fin de determinar si estos mismos fenómenos tenían lugar durante el desarrollo embrionario de la rata procedimos a analizar el micro-ambiente cerebral durante la etapa prenatal. Para este estudio tomamos muestras de cerebro de embriones entre los días E14,5 (día 14,5 de gestación) y P1 (primer día postnatal) ya que es en este periodo en el que se producen los principales fenómenos de diferenciación neuronal durante el desarrollo embrionario (Altman y Bayer 1994).

Con la intención de conocer el posible papel de la alfa-fetoproteína (AFP) en el desarrollo embrionario del cerebro, investigamos su presencia en diferentes periodos de diferenciación de las estructuras embrionarias del cerebro tras el cierre del tubo neuronal (en la rata en torno a E10,5). Podemos dividir el desarrollo embrionario del cerebro en tres etapas (Altman y Bayer 1994): una etapa inicial (E11 a E14) predominantemente proliferativa, una etapa intermedia (E15 a E18) en la que aparecen las primeras estructuras en diferenciación a la vez que progresa el crecimiento del cerebro y una etapa final (E20 hasta el parto), que supone la disolución gradual del neuroepitelio y la formación de las principales estructuras cerebrales. Ya que nuestro objetivo inicial era conocer el posible papel de la AFP y su relación con el ácido oleico, decidimos únicamente abordar las etapas segunda y tercera, ya que es durante estas etapas cuando se producen los principales eventos de diferenciación prenatal del cerebro a gran escala (formación de las estructuras cerebrales, neocórtex, tálamo, hipotálamo, etc).

\subsubsection{Determinación de la edad gestacional}

Con el objeto de mantener un control preciso de la edad gestacional para conocer el estadio exacto de desarrollo del embrión en cada momento, se tomaron 


\section{Alejandro García García}

las medidas del peso de los fetos, tamaño (medido como la mayor longitud existente en el cuerpo del feto) y peso de los cerebros (en peso húmedo) de animales con edades comprendidas entre E15,5 y P1. En las figuras $1 \mathrm{a}$ y $1 \mathrm{~b}$ se muestran estos valores y su representación gráfica. En ese sentido, vemos cómo los tres parámetros se ajustan a una función exponencial (figura 1c). Asimismo, en el esquema 17 de la Discusión se muestra la evolución de la relación entre el peso embrionario y el peso del cerebro a lo largo de la gestación.

Una vez obtenidos los datos, éstos se emplearon para determinar el control de la edad gestacional de los animales utilizados así como de tabla de referencia para futuras investigaciones en el laboratorio.

\subsubsection{Estudio de los niveles de MAP-2 y GAP-43}

La proteína asociada a microtúbulos (MAP-2) se expresa abundantemente en el cerebro en desarrollo y se localiza específicamente en las dendritas. Entre otras funciones se asocia a los microtúbulos para estabilizarlos y promover su ensamblaje, por lo que se considera una proteína marcadora de la diferenciación dendrítica (Sheetz y col. 1998).

Asimismo, durante los procesos de crecimiento neuronal encontramos una expresión máxima de la proteína asociada al crecimiento GAP-43. Esta proteína se localiza fundamentalmente en los axones y, sobre todo, en los conos de crecimiento. Por consiguiente, se considera a esta proteína como marcadora del crecimiento axonal (Oestreicher $y$ col. 1997).

En ese sentido, en trabajos anteriores de nuestro laboratorio se observó que el ácido oleico sintetizado por los astrocitos, en respuesta a la albúmina, es captado por las neuronas, en las cuales induce su diferenciación.

La figura 2 muestra cómo tanto la expresión de GAP-43 como la de MAP-2 aumentan a medida que progresa el desarrollo embrionario del cerebro. Cabe destacar que la pendiente del incremento en la expresión de MAP-2 presenta un pico anterior al de GAP-43, tal y como se ha visto que ocurre en el desarrollo postnatal in vivo (Velasco y col. 2003) y en neuronas en cultivo primario (datos no mostrados). 


\subsubsection{Estudio de los niveles en cerebro de las proteínas plasmáticas albúmina y alfa-fetoproteína}

Estudios previos de nuestro laboratorio mostraron cómo la albúmina en el cerebro postnatal participa en el aumento de la expresión de MAP-2 y GAP-43 (Medina y Tabernero 2002). La albúmina se encuentra en bajas concentraciones en sangre y en el líquido cefalorraquídeo durante el desarrollo embrionario (Dziegielewska, Evans, Lai y col. 1981). Sin embargo, la alfa-fetoproteína (AFP), una proteína perteneciente a la misma familia proteica que la albúmina y con propiedades y funciones muy similares a ésta (ver Introducción, sección 1.3.2.), aparece en concentraciones elevadas en plasma durante el desarrollo embrionario. Parece lógico pensar, entonces, que el cambio entre ambas proteínas entre la vida prenatal y postnatal podría estar ligado a algún fenómeno relativo al desarrollo. Son numerosos los estudios que han abordado este tema (para una revisión detallada ver: Mizejewski 2004). Por ello nos propusimos, en primer lugar, conocer los niveles de ambas proteínas plasmáticas en el cerebro durante el desarrollo embrionario.

El análisis mediante transferencia tipo Western mostró cómo la albúmina permanece en niveles bajos en el cerebro entre los días E15,5 y E18,5. Sin embargo, a partir de E19,5 los niveles de albúmina en el cerebro aumentan drásticamente y se mantienen así durante el primer día tras el parto (figura 3).

La AFP, sin embargo, presenta unos niveles elevados en el cerebro durante prácticamente todo el desarrollo embrionario, disminuyendo los días previos al parto (figura 4). Cabe destacar que los niveles de AFP presentan dos picos. Uno de ellos aparece en el día E19,5, lo cual está en consonancia con los datos descritos anteriormente en la bibliografía para el líquido cefalorraquídeo (LCR) (Dziegielewska, Evans, Lai y col. 1981). Asimismo, encontramos un segundo pico en E15,5, no descrito anteriormente en la bibliografía.

Como controles positivos de la especificidad del anticuerpo contra alfa-fetoproteína usamos plasma de neonato y plasma de adulto, encontrando señal de AFP en el primero y ausencia de señal en el segundo, en concordancia con lo descrito anteriormente en la bibliografía (Dziegielewska, Evans, Lai y col. 1981). 


\section{Alejandro García García}

Con el fin de descartar la contaminación de sangre en la muestra de homogenado de cerebro realizamos la determinación del fibrinógeno, una proteína plasmática que no pasa al cerebro. De esa manera puede observarse una ausencia de esta proteína en nuestras muestras, lo cual indica que la señal detectada para la AFP y la albúmina corresponde únicamente a las proteínas presentes en el cerebro (figura 4a) y no a las procedentes de una hipotética contaminación con sangre.

\subsubsection{Estudio de la concentración de ácido oleico libre en cerebro}

Una vez conocida la presencia de AFP en el cerebro durante el desarrollo embrionario, decidimos investigar su posible relación con la concentración de ácido oleico, ya que este ácido graso se comporta como factor neurotrófico durante la etapa postnatal, coincidiendo con la presencia de elevados niveles de albúmina en el cerebro (Medina y Tabernero 2002). Así pues, queríamos conocer la posible implicación de este ácido graso en el desarrollo del cerebro en la etapa embrionaria y, por ello, realizamos el análisis de los ácidos grasos libres mediante cromatografía líquida de alta eficacia, HPLC.

En la figura 5a) aparecen tres ejemplos de cromatograma de los días E16,5, $\mathrm{E} 20,5$ y $\mathrm{P} 1$, en los cuales podemos observar que los principales ácidos grasos presentes en el cerebro embrionario son el ácido oleico (18:1) y el ácido palmítico (16:0). Asimismo, en estos cromatogramas se observa la presencia de ácido margárico (17:0), un ácido graso no natural que se añade a la muestras como estándar interno en el proceso de extracción de ácidos grasos.

En la figura $5 b$ se puede observar cómo el ácido oleico presenta dos picos durante el desarrollo. El segundo pico aparece en el día 1 de vida postnatal y coincide con el aumento de ácido oleico durante esta etapa, ya descrito anteriormente por nuestro grupo (Polo-Hernández y col. 2010). El primer pico aparece entre los días E15,5 y E18,5 (figura 5b). Este pico puede parecer, a priori, no muy significativo, sobre todo comparado con el primero. Sin embargo, al analizar la razón entre las concentraciones de ácido oleico y ácido palmítico vemos que ambos picos son 
muy similares en magnitud (figura 5c). La relación ácido oleico / ácido palmítico resulta de gran importancia ya que proporciona un conocimiento más preciso del metabolismo del ácido oleico, al ser el ácido palmítico su principal precursor.

\subsubsection{Relación entre el ácido oleico y la alfa-fetoproteína}

Al analizar en conjunto los resultados de los niveles de AFP (figura 4) presentes en el cerebro y los resultados relativos a la síntesis de ácido oleico (figura 5c), observamos la aparición de una relación inversa entre ambos (figura 6). De esta manera comprobamos cómo aparentemente, el aumento de la síntesis de ácido oleico (definido como un aumento en la relación ácido oleico / ácido palmítico) se produce únicamente en aquellos momentos del desarrollo en que se produce una disminución de los niveles de AFP.

\subsubsection{Localización de las proteínas plasmáticas en el cerebro en desarrollo}

Una vez determinada la presencia de AFP y albúmina en el cerebro embrionario de la rata y analizada la evolución de sus niveles, quisimos determinar la localización de estas proteínas y, de esta manera, intentar determinar su relación con algunas estructuras del cerebro en formación. Para ello, se perfundieron intracardíacamente embriones de diferentes días de gestación con paraformaldehido al $4 \%$. Seguidamente los cerebros se extrajeron y cortaron en el criostato en secciones de $10 \mu \mathrm{m}$ de grosor, para la determinación posterior mediante, inmunohistoquímica de la AFP y de la albúmina. Estudiamos los días E15,5 y E19,5 ya que, tal y como se describe en la sección 4.3, la AFP presenta sus niveles máximos en esos días.

\subsubsection{Localización en el cerebro embrionario de las proteínas plasmáticas AFP y albúmina en el día E19,5 de gestación}

\subsection{Distribución de la AFP en el día E19,5}

En la figura 7 podemos observar el patrón de distribución de la AFP en el cerebro de embrión de rata de 19,5 días de gestación, a lo largo de eje rostro-caudal. 


\section{Alejandro García García}

Como era de esperar al ser una proteína plasmática, la AFP se encuentra en los vasos sanguíneos del cerebro y el plexo coroideo (figura 7c). Asimismo, la señal de AFP es fuerte en la zona ventricular $(Z V)$ y presenta un ligero marcaje en el área ventral de la zona subventricular (ZSV), aunque la señal es prácticamente nula a nivel de la zona intermedia. Durante el desarrollo del cerebro de mamíferos, las células nerviosas se generan a partir de precursores en la zona más cercana al ventrículo (ventrículo lateral, $\mathrm{VI}$ ) o zona ventricular. Estás células definen su linaje en la zona subventricular y migran radialmente para formar la placa cortical (Pc) (Gupta y col. 2002). Llama la atención que la AFP presenta una mayor intensidad en las zonas de materia blanca (Mb), a ambos lados de la subplaca (Sp), delimitándola. Asimismo, se marca con mayor intensidad la zona marginal $(\mathrm{Zm}) \circ$ capa plexiforme primaria. Destaca, sobre todo, el hecho de que la AFP presenta el mismo patrón en todas las secciones a lo largo del eje rostro-caudal.

En la figura 8 se observa el marcaje de AFP, a mayor detalle, en el área comprendida entre la subplaca y la zona marginal, mediante fotografías a diferentes aumentos. Al igual que puede observarse en la figura 7, la AFP marca intensamente dos bandas que flanquean la subplaca (8b), correspondientes con los haces axonales o materia blanca, que establecen las conexiones con la corteza. Asimismo se observa un mayor marcaje en la zona marginal. Estas dos zonas, la subplaca y la zona marginal, delimitan la placa cortical, la cual presenta un marcaje para AFP ligeramente mas débil en comparación con ellas pero mayor que, por ejemplo, la zona intermedia (8a y b). Asimismo, resulta destacable cómo el marcaje de AFP en la placa cortical presenta un patrón radial mientras que en la zona marginal y en la subplaca se asemeja más a un patrón horizontal (8c).

\subsection{Distribución de la albúmina en el día E19,5}

A continuación realizamos la inmunohistoquímica de albúmina en el cerebro fetal. En la figura 9 puede observarse cómo la albúmina presenta un patrón de localización similar al de la AFP, marcando ligeramente el plexo coroideo, la zona ventricular, la parte inferior de la zona subventricular, ambos lados de la subplaca y la zona marginal. No obstante, si bien el patrón de localización es similar, la señal de albúmina es mucho más débil que la de la AFP. De igual manera, en la figura 10 
se observa con mejor detalle la localización de la albúmina desde la subplaca hasta la zona marginal. Así vemos cómo la albúmina presenta una mayor señal en la zona marginal y en la subplaca. Al igual que puede observarse en la figura 8 para la AFP, la señal de la albúmina en la placa cortical presenta un marcaje radial desde la subplaca hasta la zona marginal.

\subsubsection{Distribución de las proteínas plasmáticas AFP y albúmina en el cerebro el día E15,5 de gestación}

\subsection{Distribución de la AFP en el día E15,5}

Tal y como se presenta en la sección 4.1.2., la AFP presenta dos picos en cerebro durante el desarrollo prenatal: uno en el día E19,5 y otro en el día E15,5 de gestación. Por tanto, a continuación decidimos analizar la localización de la AFP en el cerebro en embriones más inmaduros, en el día E15,5.

En la figura 11 puede observarse el patrón de localización de la AFP en el día 15,5, a lo largo del eje rostro-caudal. Puede observarse cómo la AFP aparece marcando nuevamente el plexo coroideo y los vasos sanguíneos. Asimismo, cabe destacar cómo la AFP aparece marcando con mayor intensidad las regiones caudales que las rostrales. En ese sentido, observamos cómo la AFP parece encontrarse marcando aquellas estructuras que se encuentran en diferenciación (denominadas como "campo diferenciante", según Altman y Bayer, (Altman y Bayer 1994)). En concreto vemos como la AFP marca de manera más intensa, la región talámica $(\mathrm{TI})$, la hipotalámica $(\mathrm{Ht})$ y sobre todo la amígdala $(\mathrm{Ag})$ (figuras $11 \mathrm{c}$ y d) y, en menor medida, las regiones mas caudales de los ganglios basales (estriado, Str y pálido, PI, figura 11c). Asimismo, encontramos los haces de fibras de la cápsula interna (Ci) marcados para la AFP.

En la figura 12 podemos observar en mayor detalle la región que en el cerebro maduro conformará la amígdala y cómo la AFP presenta una mayor señal en ella, a diferencia del núcleo estriado, adyacente a esta estructura, en el cual el marcaje es casi nulo. De igual manera, en la figura 13 podemos observar con más detalle el marcaje de la AFP en la región talámica. Así pues, en las figuras 13b y 13c puede observarse que la AFP se encuentra marcando fuertemente el núcleo reticular 
talámico y cómo este marcaje se extiende por el complejo ventrolateral nuclear y el tálamo intermedio (Tli) adyacentes. Por el contrario, no encontramos marcaje en el neuroepitelio talámico ( $\mathrm{NeT}$ ). Asímismo, vemos como en la región hipocampal (fig. 13b) la señal de la AFP es mayor en la zona en diferenciación (Hpc, hipocampo) que en la zona proliferante ( $\mathrm{NeHc}$, neuroepitelio hipocampal).

Resulta importante destacar que, en esta edad, la señal de la AFP es inversa a la densidad de cuerpos celulares que muestra la tinción de DAPI. Este hecho coincide con la presencia de marcaje para la AFP en aquellas estructuras en diferenciación, como la amígdala, el hipotálamo o el tálamo (figuras 12 y 13) y la ausencia de AFP en las áreas en proliferación, como son la región neocortical y los neuroepitelios estriatal, talámico e hipotalámico (figuras 12a y 13 a).

\subsection{Distribución de la albúmina en el día E15,5}

Al analizar la localización de la albúmina el cerebro en el día E15,5 de desarrollo (fig. 14), no encontramos marcaje en ninguna estructura a lo largo del eje rostro caudal (figura 14a y 14d), ni siquiera en el plexo coroideo (figura 14b y 14c). Este resultado coincide con los bajos niveles de albúmina observados en cerebro durante este periodo (fig. 3).

\subsubsection{Distribución de GAP-43 en el día E19,5 de desarrollo embrionario}

En la figura 15 puede observarse cómo el patrón de distribución de GAP-43 en día E19,5 es similar en las zonas caudal (15a) y rostral (15 b). Asimismo, no se observa marcaje en la zona subventricular, la zona ventricular, los vasos sanguíneos o el plexo coroideo.

En las figuras $15 \mathrm{c}$ y $15 \mathrm{~d}$ pueden observarse, con más detalle, imágenes de la región rostral.

En la figura 15c se observa cómo GAP-43 se encuentra en la zona marginal, marcando una fina capa. Asimismo, en la placa cortical encontramos un marcaje mayor en las capas corticales más externas (15c), formadas por las neuronas añadidas más tardíamente en el desarrollo. En esas capas, el marcaje de GAP-43 
dibuja los cuerpos celulares de las neuronas.

En la región que queda limitada entre el comienzo de la placa cortical y la región más ventral de la subplaca observamos un marcaje intenso y continuo, de aspecto granulado (15c). Por el contrario, en la región de materia blanca que queda por debajo de la subplaca y la zona intermedia (15a y 15b) observamos que GAP-43 dibuja los haces axonales de manera paralela al corte. Sin embargo, este patrón cambia en la región del estriado (15d), donde encontramos un patrón de marcaje de GAP-43 perpendicular al corte y con los axones agrupados en fascículos.

\subsubsection{Distribución de GAP-43 en el día E15,5 de desarrollo embrionario}

En la figura 16 puede observarse la distribución de GAP-43 en el día E15,5 de desarrollo. En ese día, la señal para GAP-43 en el cerebro es débil y difusa, sin que se puedan apreciarse los haces de axones observados el día E19,5 (fig. 15).

Tal y como se aprecia en la figura 16 (indicado mediante flechas) la señal de GAP-43 se circunscribe a las partes más externas de los hemisferios cerebrales que conformarán la zona marginal (16a) y de la amígdala (16c). También encontramos señal de GAP-43 en las zonas más externas de las regiones talámica (16b) e hipotalámica (16c), concretamente en los haces de fibras que surgen desde la cápsula interna $(\mathrm{Ci}, 16 \mathrm{c})$ y viajan alrededor de la región talámica. De hecho, podemos encontrar un ligero marcaje de GAP-43 en el complejo ventrolateral nuclear (Cvn) y en el núcleo reticular talámico (NRT) (16b).

\subsubsection{Relación entre GAP-43 y AFP en el cerebro en desarrollo}

Con el fin de determinar la relación entre la AFP y la proteína marcadora del desarrollo axonal, GAP-43, se realizó una doble inmunohistoquímica para ambas proteínas, en los días E19,5 y E15,5. Posteriormente las secciones fueron analizadas mediante microscopía confocal.

En la figura 17 aparecen representadas imágenes de secciones de cerebro de E19,5 en las que se muestra la señal para AFP (en verde) y de GAP-43 (en rojo) (en el Anexo, en la figura $A 1$ se muestra un duplicado de esta imagen en la que, 


\section{Alejandro García García}

además, aparecen marcados los núcleos en azul mediante la tinción nuclear realizada con TOPRO-3)

De tal manera, podemos determinar en qué zonas ambas proteínas colocalizan, ya que cuando existe colocalización aparece una señal de color amarillo, por la fusión de los colores verde y rojo. Así, puede observarse que ambas proteínas coinciden en las mismas regiones, pero con un patrón de gradiente inverso.

Así, puede observarse cómo ambas proteínas coinciden en áreas que delimitan con la subplaca ( $\mathrm{Sp}, 17 \mathrm{a}, 17 \mathrm{~b}$ y $17 \mathrm{c}$ ). Sin embargo, en regiones más mediales, existe una mayor señal para GAP-43 (17a) y a medida que nos desplazamos a regiones mas laterales aumenta la señal para la AFP. Respecto a las zonas que delimitan la subplaca $(\mathrm{Sp}$ ) dorso-ventralmente (figura $17 \mathrm{~b}$ y $\mathrm{c}$ ), vemos como existe un mayor marcaje para AFP y algo menor para GAP-43, en la zona de materia blanca más cercana a la placa cortical. En esa zona podemos encontrar algún punto de colocalización. Sin embargo, por debajo de este nivel, a nivel de la subplaca, el marcaje de AFP disminuye y, sin embargo, el de GAP-43 aumenta. Esta zona corresponde con la subplaca y sus células se encuentran marcadas, principalmente, con GAP-43. Cuando descendemos hasta la capa de materia blanca que se encuentra por debajo de la subplaca, podemos observar nuevamente el marcaje de GAP-43, pero este presenta un patrón de haces paralelos al corte histológico. En esta zona encontramos que el marcaje para AFP se encuentra muy disminuido y sin rastros de colocalización con GAP-43 (para una mejor resolución de esta imagen, véase el CD adjuntado). De igual manera, podemos observar cómo a lo largo de la placa cortical (Pc), la AFP parece encontrarse "rodeando" de manera radial los cuerpos celulares que forman el parénquima cortical, los cuales se encuentran teñidos débilmente para GAP-43 (17b). Asimismo, los cuerpos celulares más externos (más cercarnos a la zona marginal, $\mathrm{Zm}$ ), se encuentran teñidos más fuertemente para GAP-43. Esas células se corresponden con las neuronas añadidas más recientemente a la corteza por la migración radial (Gupta y col. 2002). En esa zona existe, igualmente, una fuerte señal para AFP, de aspecto granular, pero que no colocaliza con la GAP-43. Por el contrario, se observa una fuerte colocalización de ambas proteínas a lo largo de toda la zona marginal (figura 17d). 
De igual manera realizamos el análisis de la relación entre GAP-43 y AFP en el día E15,5 de desarrollo. En la figura 18 podemos observar microfotografías realizadas con el microscopio confocal de secciones de cerebro de E15,5, en las que se muestra la señal correspondiente a la AFP (en verde) y GAP-43 (en rojo) (en el Anexo, en la figura $A 2$, se muestra un duplicado de esta imagen en la que además aparecen marcados los núcleos en azul mediante la tinción nuclear realizada con TOPRO-3).

Se observa que la señal de GAP-43 se encuentra restringida principalmente a áreas más externas del cerebro, mientras que la AFP se localiza en zonas más internas. Así pues, no se observa prácticamente colocalización, salvo en pequeños puntos en el área hipotalámica lateral (18b), aunque la mayor parte de señal de GAP-43 está restringida a los haces de fibras que la rodean, mientras que la de AFP se encuentra en la región mas interior del hipotálamo (18a y 18b). De igual manera, se observa una clara separación de ambas proteínas en la región que conformará la amígdala (18d), encontrándose nuevamente GAP-43 en los haces de fibras más externos y AFP en las áreas mas internas. En la región talámica más interna encontramos únicamente señal para la AFP (18c), restringida al núcleo reticular talámico (NRT). Por último, no encontramos apenas señal de AFP en la región neocortical (18e), que en esta edad está formada en su mayoría por el neuroepitelio neocortical. La AFP aparece únicamente en algunas células de la zona marginal. Asimismo, la GAP-43 se encuentra marcando únicamente esta zona. De tal manera, encontramos también algunos puntos de colocalización en la zona marginal.

\subsection{OBTENCIÓN Y PURIFICACIÓN DE LA ALFA- FETOPROTEÍNA.}

Como hemos visto, la presencia y distribución de la AFP en el cerebro en embrionario parecen sugerir un papel importante de esta proteína en el desarrollo. Con el fin de profundizar en el conocimiento de su función, resultaba necesario el diseño de experimentos in vitro en los que pudiéramos determinar el efecto de la AFP. 


\section{Alejandro García García}

Una búsqueda sencilla en la base de datos de Biocompare (www.biocompare.com) nos muestra que las preparaciones existentes de AFP son de AFP humana y en menor medida, de primate, procedentes de muestras de suero o de origen recombinante. Desgraciadamente, a pesar de existir preparados de la proteína en su forma nativa, ésta va normalmente acompañada de azida sódica como conservante, lo que imposibilita el uso de esta proteína en estudios in vitro. Es por ello que consideramos necesario obtener, de forma fisiológica y económica, AFP de rata y cuyo proceso de purificación no implicase la desnaturalización de la proteína, ya que como se ha explicado en la Introducción en la sección 1.3.2.1, se trata de una proteína de muy complicada renaturalización.

\subsubsection{Selección del material de partida.}

Con el fin de determinar el material de partida óptimo para la obtención de AFP de rata se consultó numerosa bibliografía referente a la obtención y purificación de esta proteína, analizando los pros y los contras de cada uno de los métodos de purificación.

En primer lugar nos planteamos la posibilidad de la obtención de una proteína recombinante, debido a las ventajas que presentan estos métodos en la obtención, automatización y purificación de las proteínas. Sin embargo, el clonaje de la proteína en Escherichia coli produciría la obtención de una AFP sin glicosilar, ya que las bacterias carecen de la maquinaria necesaria para ese proceso. En ese sentido algunos autores han sugerido que las glicosilaciones no suponen un impedimento para la obtención de una forma de AFP perfectamente plegada (Leong y Middelberg 2007). Sin embargo, otros autores evidencian la necesidad de los restos glicídicos para que la AFP pueda llevar a cabo su función (Gillespie y Uversky 2000; Park y col. 2010). De esta manera, y aunque no existe un consenso al respecto, descartamos la obtención de AFP mediante clonación.

En segundo lugar, analizamos la posibilidad de obtener la AFP a partir de muestras de tejido embrionario o de plasma embrionario. Este método aseguraría la obtención de una AFP igual a la sintetizada in vivo de manera natural. Ese material de partida ha sido utilizado por numerosos autores para la obtención de AFP 
(Twomey y Sweet 1976; Miyazaki y col. 1981; Allen y col. 1993) y durante mucho tiempo supuso la principal fuente de esa proteína. Sin embargo, éste método presenta un gran inconveniente, que es la gran cantidad de proteínas presentes en el plasma, material de partida. Debido a ello, el proceso de purificación a partir de ese material implica un gran número de pasos, tales como columnas de inmunoafinidad, separación en geles de acrilamida, cromatografía de afinidad, etc. Éstos métodos someten a las proteínas a condiciones no fisiológicas (cambios de $\mathrm{pH}$, cambios en la fuerza iónica, etc) y a la presencia de contaminantes que habrán de ser eliminados posteriormente del preparado. Por todo ello, descartamos también esta fuente como material de partida.

Por último, estudiamos el uso de líneas celulares de hepatoma. Mediante el uso de éstas células podíamos obtener una AFP igual a la producida por las células del hígado y con una contaminación mínima de otras proteínas El uso de líneas de hepatoma para la obtención de AFP ya ha sido descrito por otros autores (Newman 1979; Tecce y Terrana 1990; Bennett y col. 1998; Carlini y col. 2007). Sin embargo, hasta lo que hemos podido encontrar en la literatura, estos métodos de purificación se centran en la obtención de AFP humana, si bien los procedimientos descritos en ellos pueden usarse como base para la obtención de un método de purificación de AFP de rata. De esta manera encontramos dos líneas de hepatoma de rata productoras de AFP, la línea McA-RH 7777 (Morris Hepatoma 7777) y la línea McA-RH 8994 (Morris Hepatoma 8994) (ATCC CRL-1601 y CRL1602 respectivamente). Ambas son líneas celulares obtenidas a partir de hepatomas químicamente inducidos (Becker y col. 1976), procedentes de hígado de rata y que secretan AFP y albúmina al medio. Después de analizar la bibliografía decidimos utilizar la línea McA-RH 7777, ya que la producción de AFP por parte de esta línea es mucho mayor (350 \pm 57 ng / 10 células a las 28 horas) con una producción de albúmina mínima (no detectable por otros autores: Hughes y col. 1982). Esta línea celular es objeto de estudio en el laboratorio de la Dra. Ma Ángeles Serrano, del Departamento de Bioquímica y Biología Molecular, quien amablemente nos cedió las células. 


\subsubsection{Producción de AFP por parte de las células McA- RH 7777}

Con objeto de desarrollar un método para la obtención de AFP de rata se estudió la evolución en la liberación de la AFP y albúmina por parte de las células de la línea McA-RH 7777 de hepatoma de rata en cultivo, a lo largo del tiempo.

En la figura 19a se presenta una inmunocitoquímica realizada con el anticuerpo policlonal contra AFP humana. En esta imagen se observa cómo el citoplasma de las células contiene AFP. En la figura 19b se puede comprobar cómo la cantidad de AFP presente en el medio aumenta con el tiempo de cultivo. Asimismo, se incrementa la cantidad de albúmina presente en el mismo, indicando que estas células sintetizan y liberan AFP y, en menor medida, albúmina al medio de cultivo. Además, se observa que la cantidad de AFP producida por las células se mantiene tras cambiar el medio por un medio fresco de cultivo (figura 19c). Por ello, decidimos recoger los medios de cultivo en intervalos de 24 horas hasta un máximo de 4 veces, momento en que las células comienzan a despegarse.

Tras este proceso obtenemos un gran volumen de medio de cultivo que contiene AFP para su posterior purificación y, en menor medida, albúmina, la cuál ha de ser retirada del medio.

\subsubsection{Proceso de purificación}

Una vez determinada la cinética de producción de AFP por parte de las células de hepatoma de rata McA-RH 7777, desarrollamos un proceso de purificación de la AFP liberada por las células al medio. Durante el desarrollo de dicho método se planificaron una serie de requisitos:

- El proceso de obtención y purificación de la AFP no puede implicar ningún tratamiento agresivo ni desnaturalizante, ya que esta proteína no puede volver a renaturalizarse (Gillespie y Uversky 2000) o es de muy complicada renaturalización (Leong y Middelberg 2006).

- El número de pasos que comprende la purificación ha de ser el mínimo posible para evitar la pérdida de proteína. 
- El proceso de purificación ha de ser escalable.

- El grado de pureza ha de ser óptimo para su uso en estudios in vitro y el purificado obtenido ha de mantener una actividad biológica medible y reproducible.

De tal manera diseñamos un proceso de purificación que comprendía los siguientes pasos:

1) Concentración del medio de hepatoma.

En la bibliografía consultada para la obtención de AFP se usan diferentes métodos, tales como la concentración por centrifugación (Bennett y col. 1998), o por flujo tangencial (Tecce y Terrana 1990). En nuestro caso, para la concentración inicial decidimos optar por el uso de un concentrador de flujo tangencial, al permitir este método la concentración de grandes volúmenes. Asimismo, decidimos usar un filtro tangencial con un tamaño de exclusión molecular de $50 \mathrm{kDa}$, ya que la AFP de rata tiene un peso molecular de $68,4 \mathrm{kDa}$.

2) Retirada de la albúmina del medio.

En la bibliografía consultada encontramos muy pocos trabajos relativos a la retirada de albúmina mediante cromatografía de inmunoafinidad (Twomey y Sweet 1976). La mayoría de los artículos consultados relativos a la purificación de AFP (Newman 1978, 1979; Allen y col. 1993) utilizan para la retirada de albúmina del purificado un procedimiento de cromatografía de afinidad, mediante el uso de un colorante reactivo (Travis y Pannell 1973). En nuestro caso, usamos una columna con el colorante azul de cibacrón F3GA, tal y como describe Miyazaki (Miyazaki y col. 1981). La albúmina queda atrapada en la columna y ésta puede ser recuperada o directamente eliminada. La ventaja principal de éste método es que la AFP no se somete a condiciones extremas de $\mathrm{pH}$ o fuerza iónica, ya que simplemente es eluida en un tampón fosfato, quedando la albúmina atrapada en la columna.

Para poder utilizar esta columna, la fracción segunda (ver tabla 3) ha de ser dializada en el tampón de aplicación. Tras esta diálisis aparece un precipitado blanquecino y de aspecto viscoso, que puede ser retirado fácilmente centrifugando a $2.000 \times \mathrm{g}$ durante 5 minutos, a $4^{\circ} \mathrm{C}$. Los análisis posteriores demostraron que este precipitado arrastra una cantidad despreciable de AFP (fig. 20a). Este 


\section{Alejandro García García}

precipitado podría formarse por agregados de restos de proteínas o péptidos presentes en la disolución. No obstante, este precipitado no puede volver a ser resuspendido en el tampón de aplicación al restaurar la fuerza iónica de la disolución ni tampoco calentándolo (datos no mostrados). Asimismo, presenta una baja solubilidad en los detergentes utilizados en la transferencia tipo Western. No hemos podido determinar la naturaleza exacta de este precipitado. Sin embargo, dado que la aparición de este precipitado no disminuye la cantidad de AFP presente en la fracción obtenida tras el proceso de diálisis (fracción 4), ni tampoco interfiere en los siguientes pasos del proceso de purificación, es desechado del purificado.

Siguiendo este procedimiento se obtiene una AFP en un tampón fosfato libre de albúmina.

3) Segunda concentración de la alfa-fetoproteína.

En este momento del proceso de purificación la AFP está libre de albúmina pero su concentración es relativamente baja para su uso en estudios in vitro. En este punto la utilización de un sistema Pellicon, como el usado en la primera concentración, resultaría totalmente inadecuada, ya que este sistema es óptimo para volúmenes mayores. Para ello empleamos un sistema adaptado para volúmenes más pequeños, como es el sistema de ultraconcentración mediante centrifugación.

4) Diálisis final de la alfa-fetoproteína.

Por último la AFP se dializó en tampón Elliot (Elliott 1969), con el fin de eliminar los restos de contaminantes procedentes del proceso de purificación, obteniendo una preparación de AFP en un tampón fisiológico, apta para su uso en estudios in vitro.

En la figura 20 pueden observarse las diferentes características de las fracciones obtenidas en el proceso de purificación de AFP. Así, en la figura 20a vemos la presencia de AFP y albúmina en cada una de estas fracciones mediante WesternBlot. Para ello se cargaron $2 \mu \mathrm{g}$ de cada una de las fracciones utilizadas, que se resolvieron mediante electroforesis en un gel de poliacrilamida al $10 \%$. Posterior- 
mente las proteínas se transfirieron a una membrana de PDVF y se incubaron con los anticuerpos contra AFP y albúmina. Asimismo se cargaron en el gel dos controles, es decir, un preparado comercial de AFP humana y otro de albúmina sérica bovina. Además, también se incluyó la albúmina sobrante del proceso de purificación, obtenida a partir de la albúmina retenida en la columna y tratada de igual manera que la AFP (es decir concentrada y dializada).

\begin{tabular}{|c|c|}
\hline Fracción & Descripción \\
\hline $\begin{array}{l}1 \text { Medio de hepatoma ini- } \\
\text { cial. }\end{array}$ & $\begin{array}{l}\text { El punto de partida de la purificación resultado de } \\
\text { reunir todos los medios recogidos. }\end{array}$ \\
\hline $\begin{array}{l}2 \text { Medio de hepatoma } \\
\text { concentrado. }\end{array}$ & $\begin{array}{l}\text { El medio concentrado en moléculas mayores de } 50 \\
k D a \text {. }\end{array}$ \\
\hline 3 Permeado. & $\begin{array}{l}\text { Fracción desechada de la concentración. Moléculas } \\
\text { menores a } 50 \mathrm{kDa} \text {. }\end{array}$ \\
\hline $\begin{array}{l}4 \text { Medio concentrado y } \\
\text { dializado. }\end{array}$ & Diálisis en tampón de aplicación de la fracción 2 . \\
\hline $\begin{array}{l}5 \text { Precipitado residual de } \\
\text { la diálisis. }\end{array}$ & Precipitado que aparece tras realizar la diálisis. \\
\hline 6 Pre-eluato. & $\begin{array}{l}\text { Fracción desplazada de la columna al aplicar la frac- } \\
\text { ción } 4 \text { en la columna de retención de albúmina. }\end{array}$ \\
\hline 7 Eluato. & $\begin{array}{l}\text { Es la fracción obtenida tras lavar la columna con tam- } \\
\text { pón de aplicación. }\end{array}$ \\
\hline \multicolumn{2}{|l|}{$\begin{array}{l}8 \text { Albúmina retenida en la } \\
\text { columna. }\end{array}$} \\
\hline 9 Eluato concentrado. & $\begin{array}{l}\text { Esta fracción es la suma de la fracción de eluato y } \\
\text { pre-eluato concentrada con un filtro Amicon. }\end{array}$ \\
\hline 10 AFP final. & Fracción 9 dializada en tampón Elliot. \\
\hline
\end{tabular}

Tabla 3.- Descripción de las fracciones analizadas en la figura 20. El medio de hepatoma se procesó para la purificación de la AFP tal y como se describe en Material y métodos. En esta tabla se describen las fracciones analizadas en la figura 20. 
La figura 20b corresponde a los espectros de absorbancia de algunas de estas fracciones. Cabe destacar cómo, al final del proceso de purificación se obtiene un único pico definido a $280 \mathrm{~nm}$ correspondiente con el máximo de absorción para las proteínas. Así mismo desaparece la absorbancia debida a otras sustancias y, en especial, el pico que aparece a $560 \mathrm{~nm}$, correspondiente al máximo de absorbancia de la forma básica del rojo fenol (Duggleby y Northrop 1989).

En la tabla adjunta (tabla 3) se describen las diferentes fracciones obtenidas a lo largo del proceso de purificación de AFP.

\subsubsection{Determinación de la pureza del resultado de la purificación.}

Con el fin de determinar el grado de pureza, $1 \mu \mathrm{L}$ del resultado de la purificación $(0,894 \mu \mathrm{g} / \mu \mathrm{L})$ se analizó mediante electroforesis bidimensional. En la figura 21a puede observarse el resultado de dicha separación en una tinción de plata del gel obtenido. Puede observarse claramente un punto definido en torno a un peso molecular de $65 \mathrm{kDa}$ y un punto isoeléctrico en torno a 5 (ver flecha). Estos valores corresponden a los valores esperados para la AFP de rata (Liu y col. 2007). A continuación, transferimos el gel a una membrana de nitrocelulosa e incubamos con el anticuerpo contra la AFP humana. En la figura 21b observamos el resultado de esta incubación. Como puede observarse, la mancha central reacciona con el anticuerpo para la AFP. Sin embargo, después del "stripping" para eliminar el anticuerpo primario, la incubación con el anticuerpo para la albúmina de rata no da señal alguna.

Seguidamente quisimos analizar mediante espectrometría de masas, MALDITOF, el producto purificado. Para ello, la mancha central observada en la tinción de plata (figura 22a) fue recortada y sometida a digestión en gel con tripsina. El análisis de los fragmentos peptídicos obtenidos (figura 22b) se realizó mediante espectrometría de masas tipo MALDI-TOF y confirmación con la base de datos SwissProt o MSDB no redundante. De esa manera comprobamos que la huella peptídica de la mancha central corresponde, efectivamente, a la AFP de rata (figura 22c). 
Los resultados mostrados en las figuras 21 y 22 corresponden con los análisis realizados al purificado denominado como AFP-Lote 2. Este lote rindió un grado de pureza mayor (en torno al 90\%) en comparación al purificado denominado como lote 1 (pureza en torno al 70\%) obtenido anteriormente. En el anexo se adjunta información detallada de los lotes.

Asimismo, en la tinción de plata observamos algunas manchas cuantitativamente mucho menos significativas, que fueron identificadas por MALDI-TOF, como alfa-1-antitripsina, T-kininógeno y proteína disulfuro isomerasa (Uniprot Accesssion numbers: P17475, P08932, P04785, respectivamente). Estas proteínas aparecen principalmente en el lote 1 , representando el $15,75 \%$, el 4,06\% y el $2,53 \%$ del contenido de proteínas del purificado, respectivamente. En el lote 2 la presencia de estas proteínas es prácticamente nula

\subsection{EFECTO DE LA ALFA-FETOPROTEÍNA EN EL SISTEMA NERVIOSO CENTRAL EN DESARROLLO.}

Una vez obtenida una fuente uniforme y asequible de AFP de rata, quisimos comprobar el efecto de esta proteína sobre las células del cerebro. Para ello, realizamos cultivos primarios de neuronas y astrocitos con objeto de analizar el efecto de la AFP en estas dos poblaciones celulares. Asimismo, realizamos cultivos organotípicos de rodajas de cerebro con objeto de determinar el efecto de esta proteína en las células del sistema nervioso central (SNC) durante el desarrollo.

\subsubsection{Efecto de la AFP sobre la morfología de las neuronas en cultivo primario}

En primer lugar analizamos el efecto de la AFP sobre las neuronas en cultivo primario. Para ello empleamos un medio definido sin suero, para evitar la presencia de proteínas plasmáticas.

En la figura 23, podemos comprobar el efecto de concentraciones crecientes de AFP sobre la morfología de las neuronas en cultivo primario. Así, se observa una 


\section{Alejandro García García}

disminución de las ramificaciones celulares así como del número de células a medida que aumenta la concentración de AFP en el medio de cultivo.

\subsubsection{Efecto de la AFP sobre la viabilidad neuronal}

Tras observar el efecto que la AFP tenía sobre la morfología de las neuronas en cultivo primario, decidimos cuantificar la viabilidad neuronal mediante el método colorimétrico del MTT. De esa manera, en la figura 24a puede comprobarse cómo la viabilidad neuronal disminuye a medida que aumenta la concentración de AFP presente en el medio, ajustándose a una función exponencial (figura 24b). El análisis estadístico de los resultados mostró que la AFP induce una disminución significativa de la viabilidad de, aproximadamente, el $20 \%$ a concentraciones superiores a $0,000625 \%(p / v)$.

\subsubsection{Efecto de la AFP sobre la proliferación neuronal in vitro}

Puesto que nuestros resultados indican que la AFP disminuye el número de células en cultivo, quisimos saber si se trataba de un efecto sobre la proliferación celular.

Para ello incubamos las neuronas con BrdU durante 24 horas, en ausencia o en presencia de diferentes concentraciones de AFP. En la figura 25a pueden observarse fotomicrografías de las células que han incorporado la BrdU. Los núcleos se tiñeron con DAPI. En la figura 25b se representa, mediante un gráficoel resultado de la cuantificación de las células BrdU positivas respecto del total de células. Como se puede observar, la AFP a bajas concentraciones $(0,0005 \%)$ produce un ligero aumento en el porcentaje de células BrdU positivas (en torno al 15\%).

\subsubsection{Efecto de las otras proteínas presentes como trazas en el purificado de AFP}

Tras comprobar el efecto de la AFP sobre la viabilidad neuronal in vitro, quisimos corroborar que este efecto se debía a la AFP "per se" y no a alguna de las proteínas que copurificaban en cantidades traza junto a la AFP. Así, incubamos neuro- 
nas en cultivo primario durante 72 horas con concentraciones crecientes de AFP y con concentraciones equivalentes de las tres proteínas copurificadas. Estas proteínas son la alfa-1-antitripsina, el T-kininógeno y la disulfuro isomerasa (ver figura 26a). Las concentraciones utilizadas fueron proporcionales a las presentes en el purificado del lote 1 en relación a la AFP. Estas proteínas representaban 15,75\%, el $4,06 \%$ y el $2,53 \%$, respectivamente y fueron añadidas en esas proporciones al cultivo primario de neuronas (por ejemplo, para la condición de $100 \mu \mathrm{g} / \mathrm{mL}$ de AFP se añadieron 15,75 $\mu \mathrm{g} / \mathrm{mL}$ de alfa-1-antitripsina, 4,06 $\mu \mathrm{g} / \mathrm{mL}$ de T-kininógeno y $2,53 \mu \mathrm{g} / \mathrm{mL}$ de disulfuro isomerasa). Cabe destacar que estas proteínas prácticamente han desaparecido en el lote 2 (ver documentación adjunta relativa a los lotes en el anexo). El figura 26a se representa el efecto de estas proteínas sobre la viabilidad celular medida mediante MTT. En este sentido, se confirma que tal y como se describió en el apartado 4.3.1., la AFP produce una disminución de la viabilidad neuronal de manera dosis dependiente. Sin embargo, concentraciones equivalentes de la alfa-1-antitripsina, T-kininógeno y de disulfuro isomerasa no produjeron cambios en la viabilidad. Por tanto, se descarta que el efecto encontrado sobre la viabilidad celular se deba a trazas de otras proteínas presentes el purificado de la AFP.

\subsubsection{Efecto de la AFP desnaturalizada sobre la morfología y la viabilidad neuronales}

Con objeto de determinar si el efecto observado se debía a la AFP y no a otros productos de naturaleza no proteica presentes en el purificado, procedimos a desnaturalizar el resultado de la purificación y analizar su efecto sobre las neuronas en cultivo primario.

En la figura 27 puede observarse que la AFP produjo de nuevo una disminución significativa de la viabilidad de las neuronas en cultivo primario. Sin embargo, la desnaturalización del purificado, mediante hervido a $100^{\circ} \mathrm{C}$ durante 10 minutos, no modificó la viabilidad neuronal. De esta manera concluimos que el efecto del purificado sobre la viabilidad neuronal se debe a un compuesto de naturaleza proteica, ya que este efecto puede ser revertido mediante desnaturalización. 


\section{Alejandro García García}

De igual manera, para asegurarnos de que este efecto se debía a la AFP y no a ningún artefacto derivado del proceso de purificación, incubamos las neuronas con la misma concentración $(0,005 \%)$ de albúmina de rata obtenida a partir del mismo medio condicionado de hepatoma que la AFP. Esta albúmina una vez separada del purificado, fue dializada y tratada de la misma manera que la AFP. Como podemos comprobar en la figura $27 \mathrm{a}$ y $27 \mathrm{~b}$, al incubar las neuronas con esa albúmina al $0,005 \%$ no se produjeron diferencias significativas respecto a la situación control, evidenciando la especificidad del efecto de la AFP presente en el purificado sobre la viabilidad neuronal.

\subsubsection{Efecto de la AFP sobre los astrocitos}

Hasta ahora hemos comprobado el efecto de la AFP sobre las neuronas, pero se desconocía, asimismo, su efecto en otros tipos celulares del cerebro. En ese sentido, algunos autores han descrito como los efectos in vitro observados para la AFP dependen del tipo celular utilizado (Dudich y col. 1998). Por ello quisimos comprobar el efecto de la AFP en células gliales en concreto en astrocitos. Para tal fin se usaron astrocitos en cultivo primario crecidos en suero durante 14 días tras los cuales se retiró el suero y los astrocitos se incubaron durante 72 horas en DMEM, al que se añadieron concentraciones crecientes de AFP. Posteriormente se determinó la viabilidad mediante MTT.

En la figura 28 puede observarse el efecto de la AFP sobre la viabilidad de los astrocitos in vitro. Como puede observarse, la AFP no produjo cambios significativos en la viabilidad. Este resultado sugiere un efecto específico de la AFP sobre las neuronas, ya que no se observó efecto alguno sobre los astrocitos.

\subsubsection{Efecto de la AFP sobre la apoptosis neuronal in vitro}

Una vez comprobado que la AFP inducía la disminución de la viabilidad neuronal in vitro, quisimos averiguar si esa disminución se debía a la inducción de un proceso apoptótico, tal y como se ha demostrado con otros tipos celulares (Semenkova y col. 2003). 
El número de neuronas apoptóticas fue determinado mediante el método de tínción tipo TUNEL, que marca los lugares en los que se ha producido la rotura del DNA. Mediante este método podemos identificar las células que están en un proceso avanzado de apoptosis.

Para ello, sembramos neuronas en cultivo primario en ausencia de AFP (MD, medio definido) o presencia de AFP al 0,005\% o AFP al 0,01\%. Tras 72 horas, las células se fijaron con paraformaldehido al $4 \%$ y posteriormente se tiñeron con el método de TUNEL, quedando marcadas en color verde aquellas células que presentan fragmentos rotos de DNA. Los núcleos se tiñeron mediante ioduro de propidio (IP, en rojo). Una vez teñidas, se fotografiaron al menos 5 campos diferentes por placa y se cuantificó el número de células TUNEL positivas respecto al número de células totales por campo.

En la figura 29a puede observarse cómo en la condición control (MD) aparecen muy pocas células apoptóticas mientras que a medida que se incrementa la concentración de AFP en el medio el número de células apoptóticas aumenta. En la figura 29b se muestra el resultado de la cuantificación de las células TUNEL positivas respecto del total de células (visualizadas con IP) por campo. Comprobamos entonces que a concentraciones de AFP de $0,005 \%$ y $0,01 \%$ se produce un aumento significativo del número de células TUNEL positivas del 70 y el 170\%, respectivamente.

\subsubsection{Efecto de la AFP sobre la diferenciación neuronal}

Los resultados mostrados en la sección 4.1.6 indican que la AFP se localiza en el cerebro en regiones con bajos niveles de expresión de GAP-43. Por ello, quisimos conocer si la AFP podría regular la expresión de esta proteína en neuronas. Por otro lado, los cambios en la morfología de las neuronas observados en la sección 4.3.1 sugerían un efecto de la AFP sobre la diferenciación neuronal.

\subsubsection{Efecto de la AFP sobre la viabilidad neuronal en presencia del complejo albúmina-ácido oleico}

En primer lugar quisimos determinar la concentración más alta de AFP que no 


\section{Alejandro García García}

modificaba la viabilidad neuronal en presencia de albúmina y ácido oleico en neuronas en cultivo primario.

Así, en la figura 30a puede observarse cómo la presencia de concentraciones de AFP mayores de 0,005\%, en presencia del complejo albúmina-ácido oleico (albúmina $2 \%$, ácido oleico10 $\mu \mathrm{M} ; \mathrm{BSA}+\mathrm{O}$ ), produce una disminución significativa del número de células vivas. Cuando se determina la viabilidad neuronal mediante el método del MTT se observa que la concentración más alta de AFP que no produjo diferencias significativas en la viabilidad neuronal en presencia de albúmina o de albúmina-ácido oleico fue de $0,0025 \%$.

Además, la AFP parece disminuir la diferenciación inducida por el efecto neurotrófico del ácido oleico (figura 30a). Cabe recordar que el ácido oleico induce in vitro la elongación de los axones y la agrupación de las neuronas por los somas. Sin embargo, la presencia de AFP, impide la aparición de tal efecto.

\subsubsection{Efecto de la AFP sobre la diferenciación neuronal en cultivos primarios}

Con objeto de analizar el efecto de la AFP sobre la diferenciación neuronal producida por el ácido oleico, analizamos la expresión de los marcadores de diferenciación MAP-2 y GAP-43. Tal y como hemos explicado anteriormente, el ácido oleico induce el aumento de ambas proteínas, tanto in vitro como in vivo. En la figura 31a puede observarse el Western-blot de ambas proteínas de 270 y 43 $\mathrm{kDa}$, respectivamente así como de la proteína de $37 \mathrm{kDa}$ GAPDH, usada como control de carga. En la figura 31b se representa la cuantificación de los niveles de MAP-2 (en amarillo) y de GAP-43 (en verde) entre las tres condiciones ensayadas. Así, el complejo albúmina-ácido oleico produjo un aumento significativo de ambas proteínas respecto de la situación control (albúmina al 2\%). Sin embargo, en estas condiciones, la adición de AFP a una concentración de $0,0025 \%$ revirtió el efecto neurotrófico del ácido oleico, no encontrándose diferencias significativas en los niveles de MAP-2 y GAP-43 respecto de la situación control (BSA al 2\%).

Este efecto se demostró igualmente mediante inmunocitoquímica. Así, en la figura 32 pueden observarse fotomicrografías de cultivos primarios de neuronas, tra- 
tados con albúmina, con el complejo albúmina-ácido oleico y con el complejo albúmina-ácido oleico más AFP. Como puede observarse como la AFP previene el aumento en los niveles de MAP-2 y GAP-43 producidos por el ácido oleico. Asimismo no se observa la agrupación de los cuerpos celulares que se observa en presencia del complejo albúmina-ácido oleico (BSA+O).

\subsubsection{Efecto de la AFP sobre la diferenciación neuronal en cultivos organotípicos}

Con el objeto de confirmar el efecto de la AFP sobre la expresión de GAP-43 empleamos cultivos organotípicos de rodajas de cerebro en los que quisimos reproducir experimentalmente las condiciones que se dan en el cerebro embrionario durante el desarrollo. Para ello, usamos como modelo cultivos organotípicos de cerebro de 17,5 días de gestación. Como hemos visto anteriormente (sección 4.1.4), en ese momento de la gestación se observan altos niveles de ácido oleico y bajos niveles de AFP en cerebro, niveles que aumentan a partir de ese momento. Así, cultivamos rodajas de $250 \mu \mathrm{m}$ de cerebro de E17,5 en presencia de albúmina, albúmina con ácido oleico y albúmina con ácido oleico y AFP, durante 48 horas.

En la figura 33 puede observarse la influencia de la AFP sobre los niveles de GAP-43 en los cultivos organotípicos. En trabajos previos de nuestro grupo se puso de manifiesto que la albúmina promovía la síntesis de GAP-43 en cultivos organotípicos, a través de la síntesis del ácido oleico. De esa manera, encontramos altos niveles de expresión de GAP-43, tanto en la condición de albúmina como en la condición de albúmina con ácido oleico (fig. 33). Sin embargo, nuestros resultados indican que la presencia de AFP disminuye significativamente los niveles de GAP-43 en los cultivos organotípicos incubados con el complejo albúmina-ácido oleico. Asimismo, los resultados previos de nuestro laboratorio indicaban que la albúmina induce la expresión de GAP-43 en el núcleo estriado en cultivos organotípicos de P1 (Polo-Hernández y col. 2010). En este sentido, nuestros resultados son coincidentes puesto que, como se puede observar en la figura 35 , la albúmina o el complejo albúmina-ácido oleico favorecen la formación de haces axonales en la ZSV, que son positivos para GAP-43 (flechas). Concretamente, en 
presencia de ácido oleico, los haces axonales en la ZSV son mayores que en presencia de albúmina sola. Además, también se observan haces marcados en la zona de materia blanca de la ZI (flecha). Sin embargo, la presencia de AFP inhibe la aparición de los haces axonales, lo que indica que la AFP inhibe la inducción de la GAP-43 promovida por el ácido el ácido oleico.

Conjuntamente, estos resultados sugieren que la AFP modula, durante la etapa embrionaria, el efecto diferenciador del ácido oleico. 
a)

\section{Valores biométricos en función de la edad gestacional}

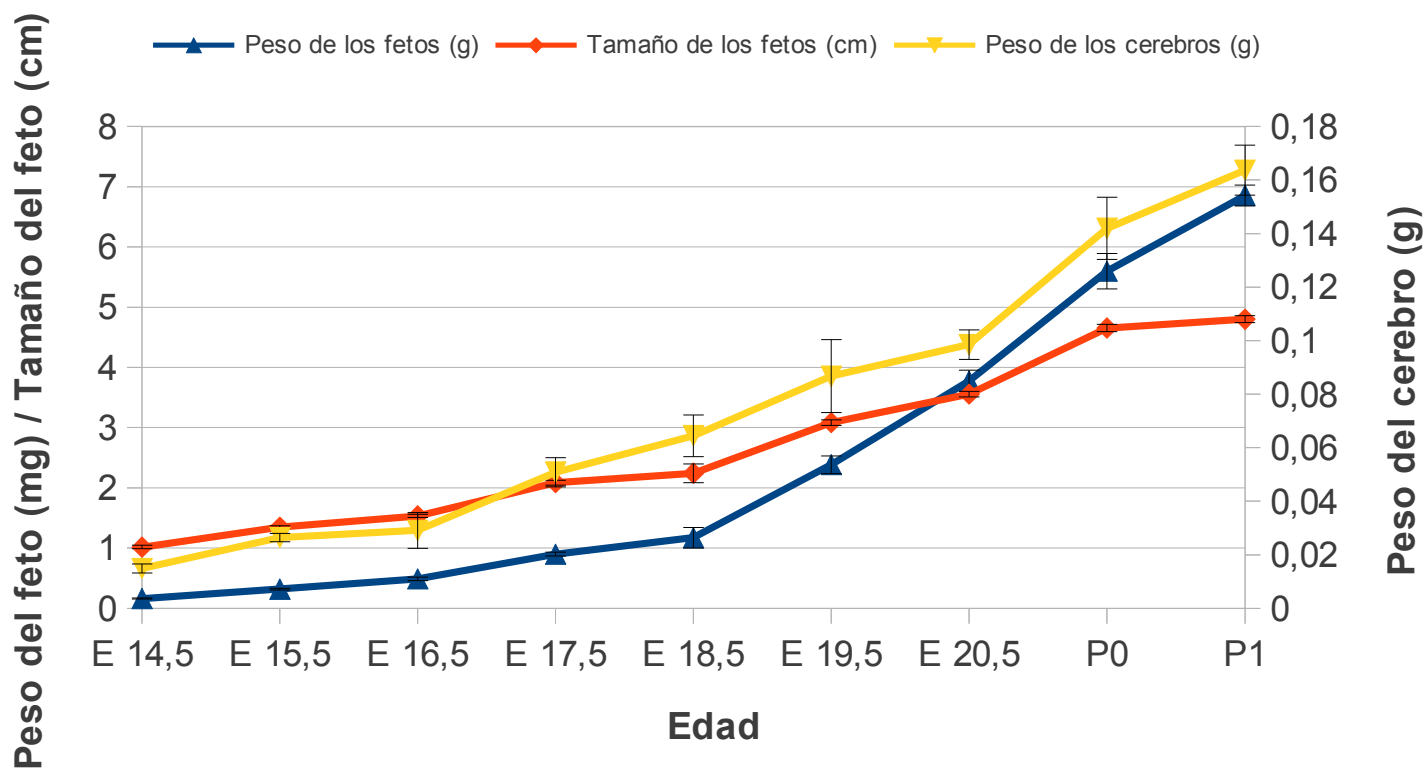

b)

\begin{tabular}{|c|c|c|c|c|c|c|c|c|c|}
\hline & E 14,5 & E 15,5 & E 16,5 & E 17,5 & E 18,5 & E 19,5 & E 20,5 & P0 & P1 \\
\hline $\begin{array}{c}\text { Peso de los } \\
\text { fetos (g) }\end{array}$ & $\begin{array}{c}0,163 \pm \\
0,105\end{array}$ & $\begin{array}{c}0,319 \pm \\
0,132\end{array}$ & $\begin{array}{c}0,489 \pm \\
0,303\end{array}$ & $\begin{array}{c}0,900 \pm \\
0,313\end{array}$ & $\begin{array}{c}1,174 \pm \\
0,169\end{array}$ & $\begin{array}{c}2,385 \pm \\
0,148\end{array}$ & $\begin{array}{c}3,775 \pm \\
0,176\end{array}$ & $\begin{array}{c}5,597 \pm \\
0,294\end{array}$ & $6,855 \pm$ \\
0,172 \\
\hline $\begin{array}{c}\text { Tamaño de } \\
\text { los fetos }\end{array}$ & $1,017 \pm$ & $1,348 \pm$ & $1,535 \pm$ & $2,086 \pm$ & $2,244 \pm$ & $3,084 \pm$ & $3,556 \pm$ & $4,655 \pm$ & $4,8 \pm$ \\
(mm) & 0,029 & 0,023 & 0,027 & 0,043 & 0,1562 & 0,048 & 0,046 & 0,059 & 0,058 \\
\hline $\begin{array}{c}\text { Peso de los } \\
\text { cerebros (g) }\end{array}$ & $0,015 \pm$ & $0,026 \pm$ & $0,029 \pm$ & $0,051 \pm$ & $0,065 \pm$ & $0,086 \pm$ & $0,099 \pm$ & $0,142 \pm$ & $0,164 \pm$ \\
\hline
\end{tabular}

c)

$$
\begin{aligned}
& \text { Tamaño de los fetos; } f(x)=0,87 \cdot 1,22^{x} \quad R^{2}=0,99 \\
& \text { Peso de los fetos; } f(x)=0,12 \cdot 1,61^{x} R^{2}=0,99 \\
& \text { Peso de los cerebros; } f(x)=0,01 \cdot 1,35^{x} \quad R^{2}=0,98
\end{aligned}
$$

Figura 1.- Análisis de los diferentes valores biométricos a lo largo del desarrollo. a) Representación gráfica de los valores biométricos de peso corporal $(\mathrm{g})$, tamaño del embrión (medido entre los puntos más distantes, $\mathrm{cm}$ ) y peso del cerebro $(\mathrm{mg})$ de los embriones usados posteriormente para el estudio del desarrollo prenatal del cerebro en la rata (Rattus norvergicus, Berkenhout, 1769). Los embriones fueron extraídos mediante cesárea post-morten de rata gestante durante los días embrionarios o retirados de la jaula tras el parto. Los resultados presentados son las medias \pm SEM de al menos tres experimentos independientes. b) Valores numéricos de los datos representados en el apartado "a)". c) Formulas correspondientes a las curvas de tendencia de cada uno de los valores biométricos a lo largo del desarrollo. 
a)

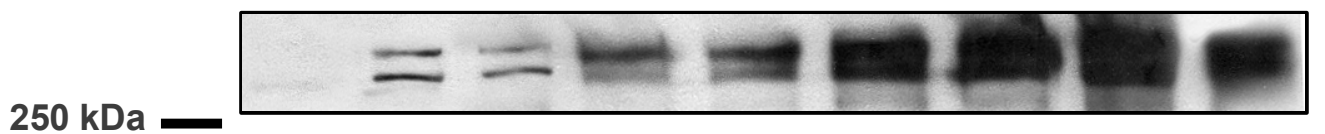

MAP-2

$250 \mathrm{kDa}$

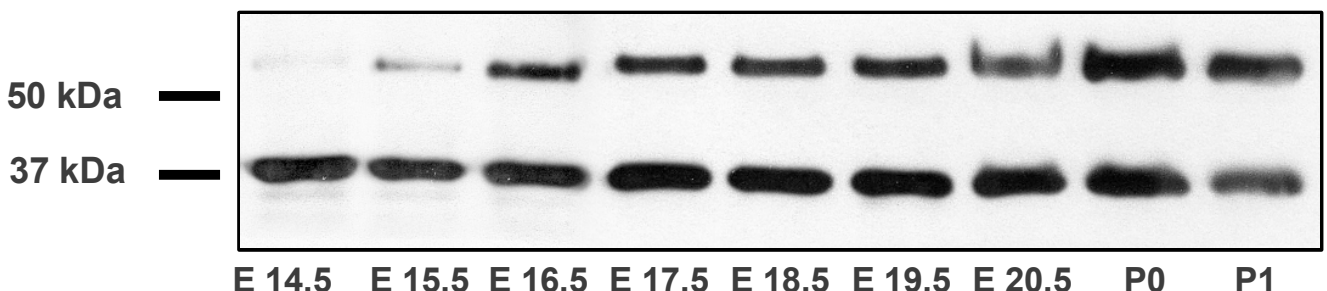

GAP-43

b)

Niveles de GAP-43 y MAP-2 durante el desarrollo.
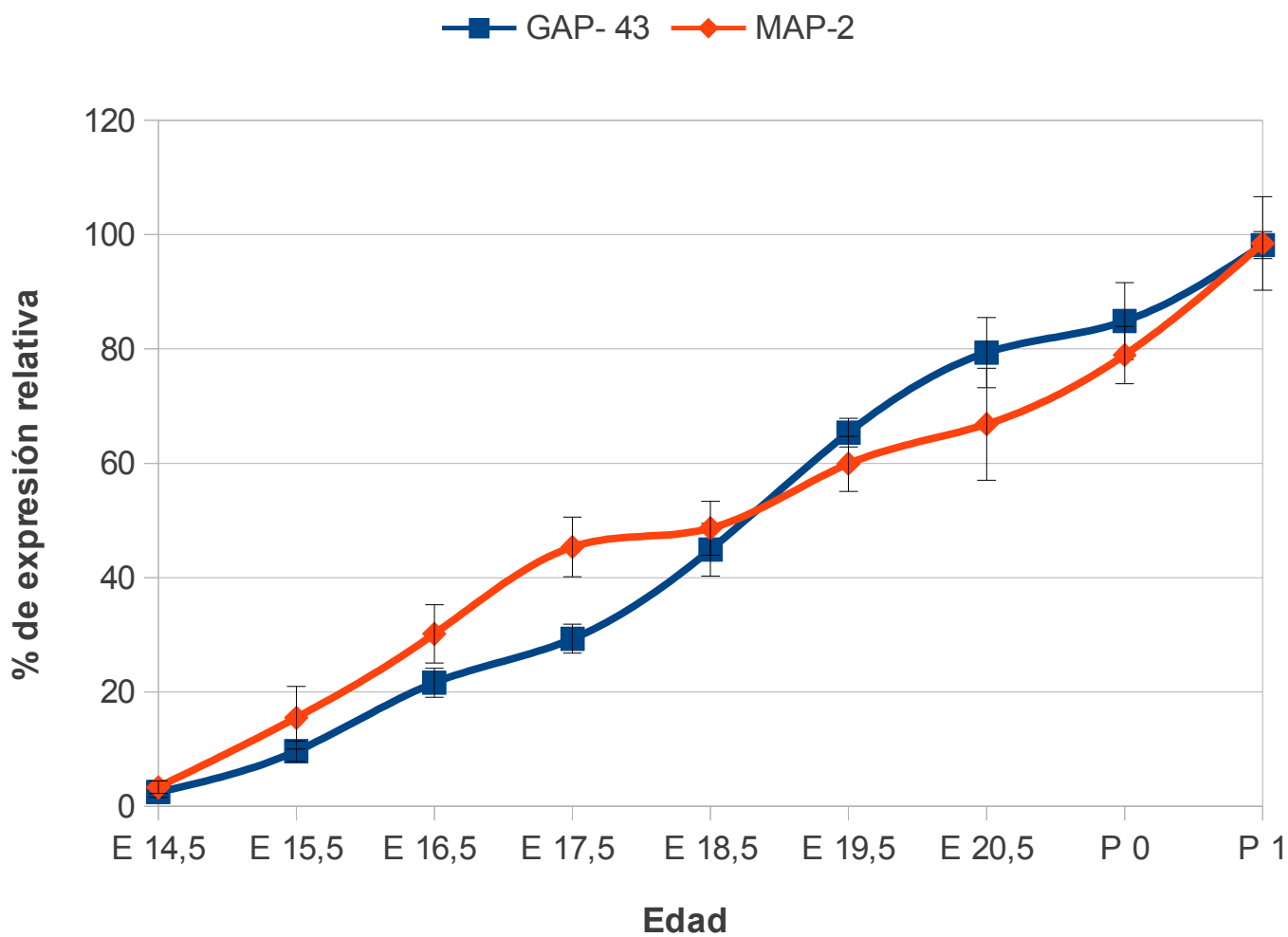

Figura 2.- Niveles de las proteínas MAP-2 y GAP-43 a lo largo del desarrollo embrionario del cerebro. a) "Western Blot" de MAP-2 y GAP-43. Los cerebros de al menos tres embriones para cada uno de los días de gestación fueron extraídos y lavados durante 10 minutos tres veces en PBS frío. Posteriormente los cerebros fueron homogenizados en tampón de extracción de proteínas, tal y como aparece descrito en Material y métodos. Posteriormente las proteínas fueron separadas mediante a electroforesis tipo SDS-PAGE, en condiciones desnaturalizantes. b) Representación gráfica de la cuantificación de los resultados obtenidos mediante "Western Blot". Los resultados se expresan como la media \pm S.E.M del porcentaje relativo de cantidad proteína respecto del día P1 y normalizados frente a GAPDH, proteína usada como control de carga. 
a)

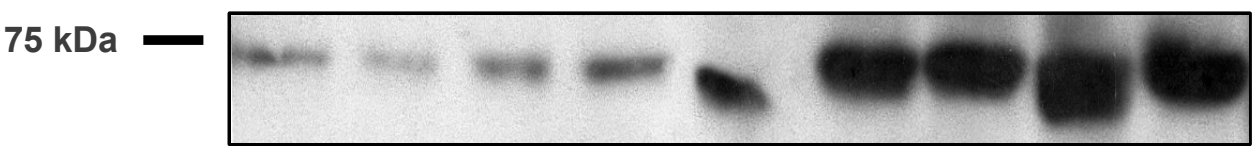

Albúmina

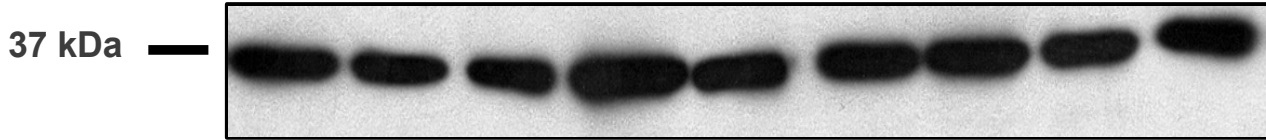

GAPDH

E 14,5 E 15,5 E 16,5 E 17,5 E 18,5 E 19,5 E 20,5 P0 P1

b)

\section{Expresión de la albúmina durante el desarrollo embrionario}

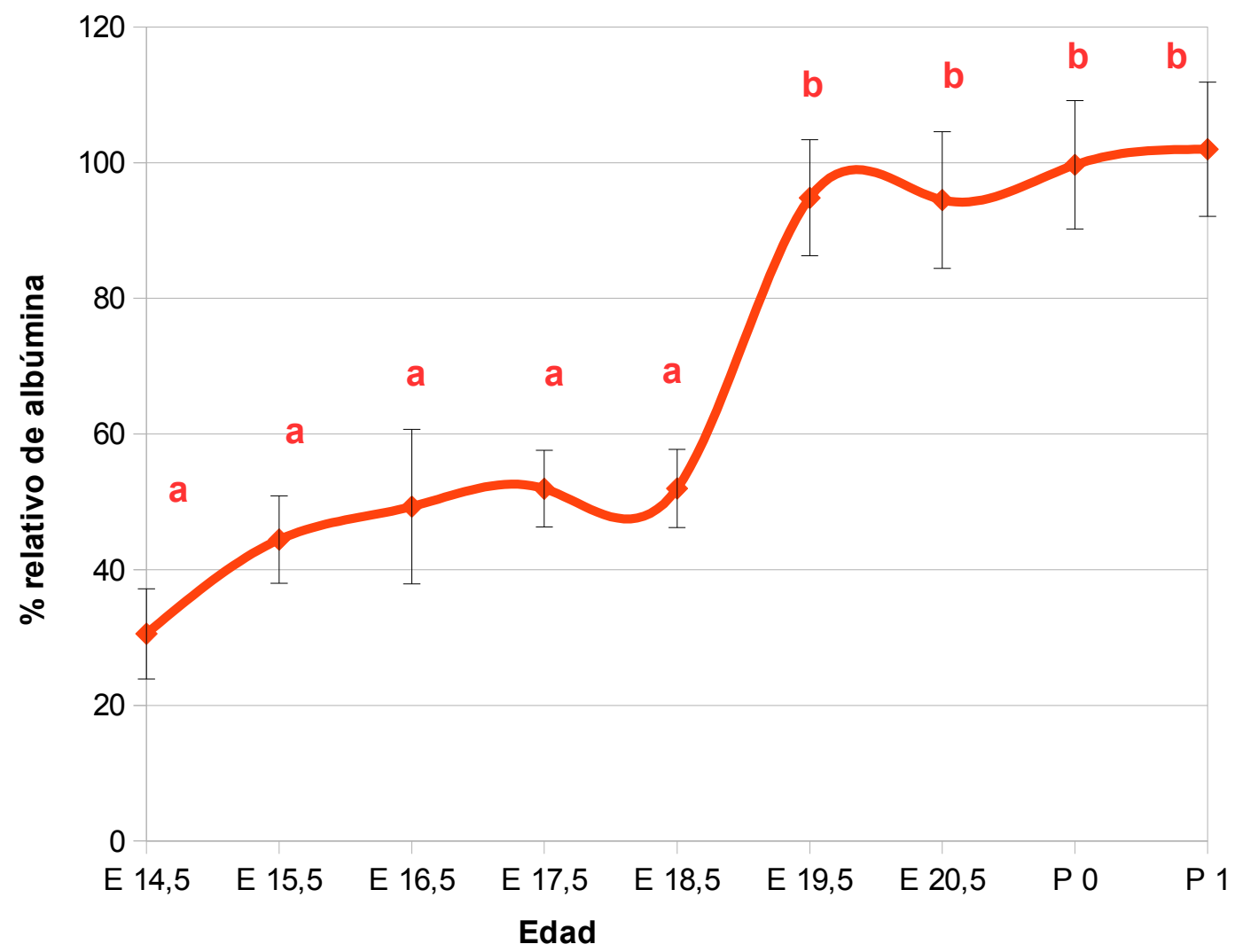

Figura 3.- Evolución de los niveles de albúmina durante el desarrollo embrionario del cerebro. a) "Western Blot" de albúmina (Alb). Los cerebros de al menos tres embriones para cada uno de los días de gestación fueron extraídos y lavados durante 10 minutos tres veces en PBS frío. Posteriormente los cerebros fueron homogenizados en tampón de extracción de proteínas, tal y como aparece descrito en Material y métodos. Posteriormente, las proteínas fueron separadas mediante a electroforesis tipo SDS-PAGE en condiciones desnaturalizantes. b) Representación gráfica de la cuantificación de los resultados obtenidos mediante "Western Blot". Los resultados se expresan como la media \pm S.E.M. del porcentaje relativo de cantidad de albúmina respecto del día P1 y normalizados frente a GAPDH, proteína usada como control de carga. Para el análisis estadístico se utilizó el test ANOVA de un factor, resultando las medias significativamente diferentes con intervalo de confianza del $95 \%$. Tras la ANOVA, las muestras se asignaron dentro de grupos homogéneos mediante el test de HSD-Tukey. Los grupos con letras iguales no presentan diferencias significativas. 
a)

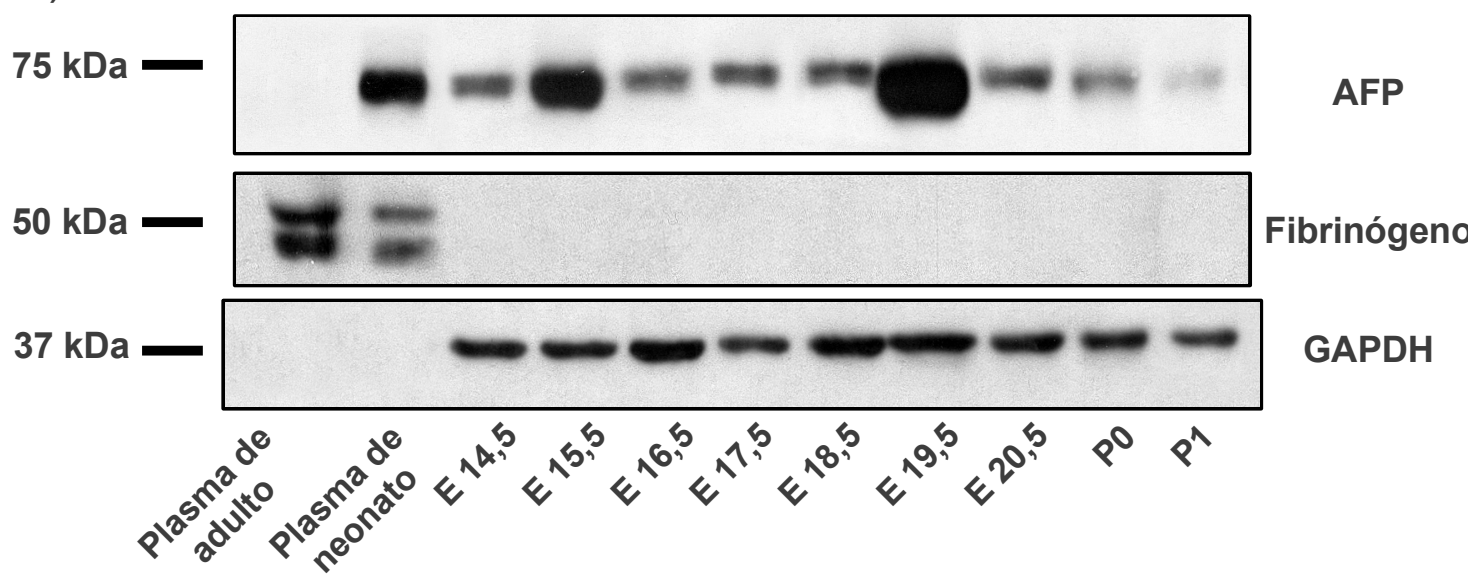

b)

\section{Expresión de AFP durante el desarrollo embrionario}

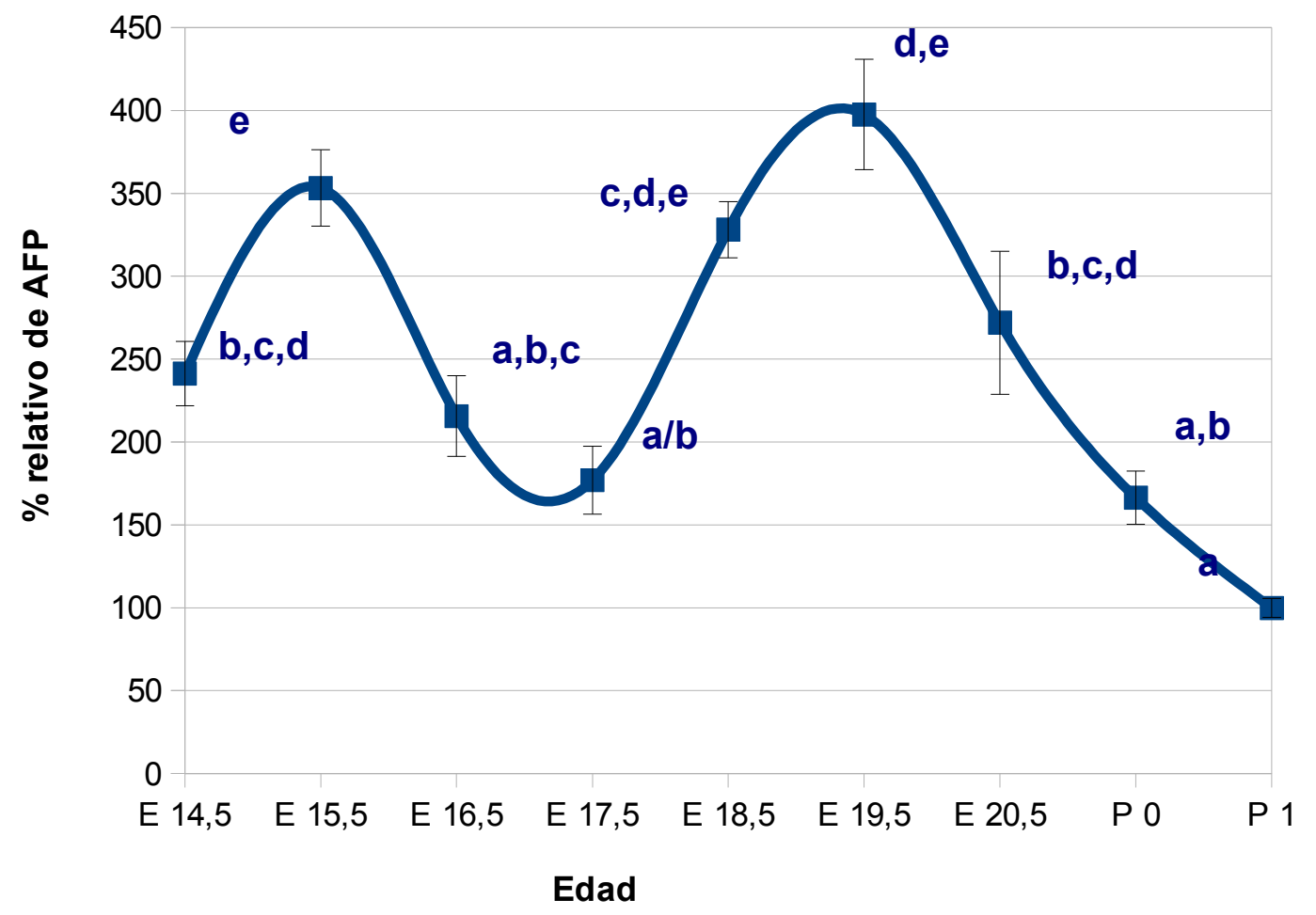

Figura 4.- Evolución de los niveles de alfa-fetoproteína durante el desarrollo embrionario del cerebro. a) "Western-Blot" de alfa-fetoproteína (AFP). Los cerebros de al menos tres embriones para cada uno de los días de gestación fueron extraídos y lavados durante 10 minutos tres veces en PBS frío. Posteriormente los cerebros fueron homogenados en tampón de extracción de proteínas tal y como aparece descrito en Material y métodos. Posteriormente, las proteínas fueron separadas mediante electroforesis tipo SDS-PAGE en condiciones desnaturalizantes. Con el fin de comprobar si la AFP y la albúmina que estábamos analizando provenían, efectívamente, del cerebro embrionario y no de la sangre, analizamos la presencia en nuestras muestras de fibrinógeno, una proteína característica del plasma sanguíneo. b) Representación gráfica de la cuantificación de los resultados obtenidos mediante "Western Blot". Los resultados se expresan como la media \pm S.E.M del porcentaje relativo de cantidad de AFP respecto del día P1 y normalizados frente a GAPDH, proteína usada como control de carga. Para el análisis estadístico se utilizó el test ANOVA de un factor, resultando las medias significativamente diferentes, con intervalo de confianza del $95 \%$. Tras la ANOVA, las muestras se asignaron dentro de grupos homogéneos mediante el test de HSD-Tukey. Los grupos con letras iguales no presentan diferencias significativas. 
a)

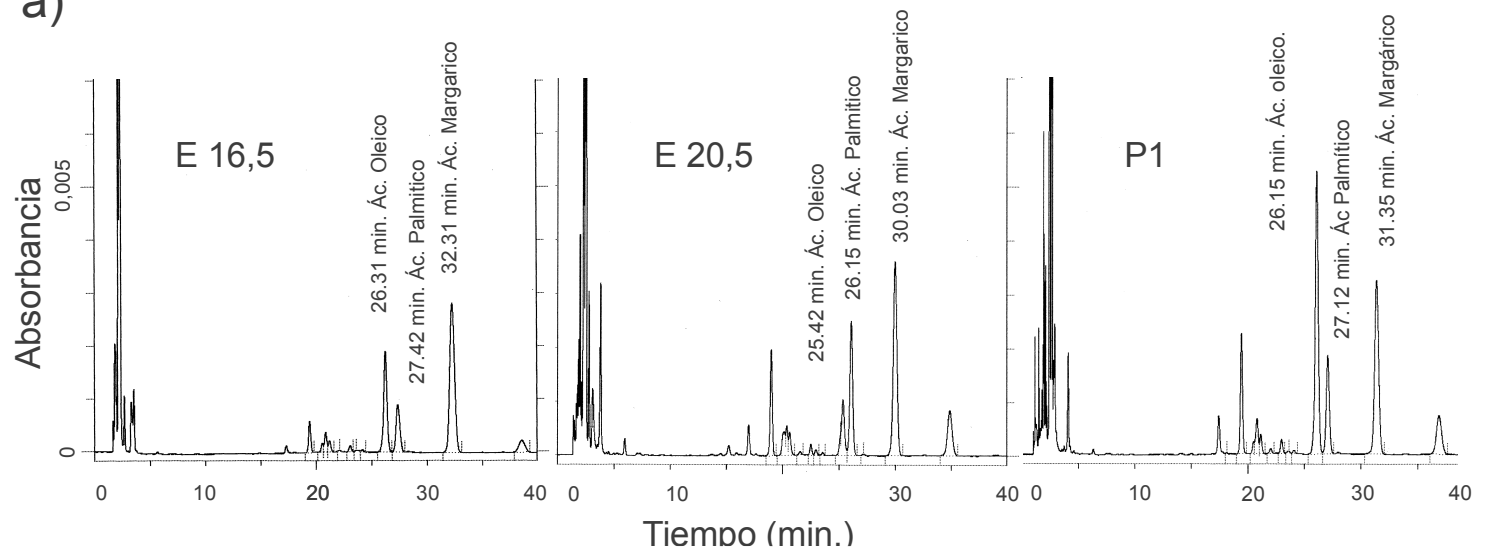

b)

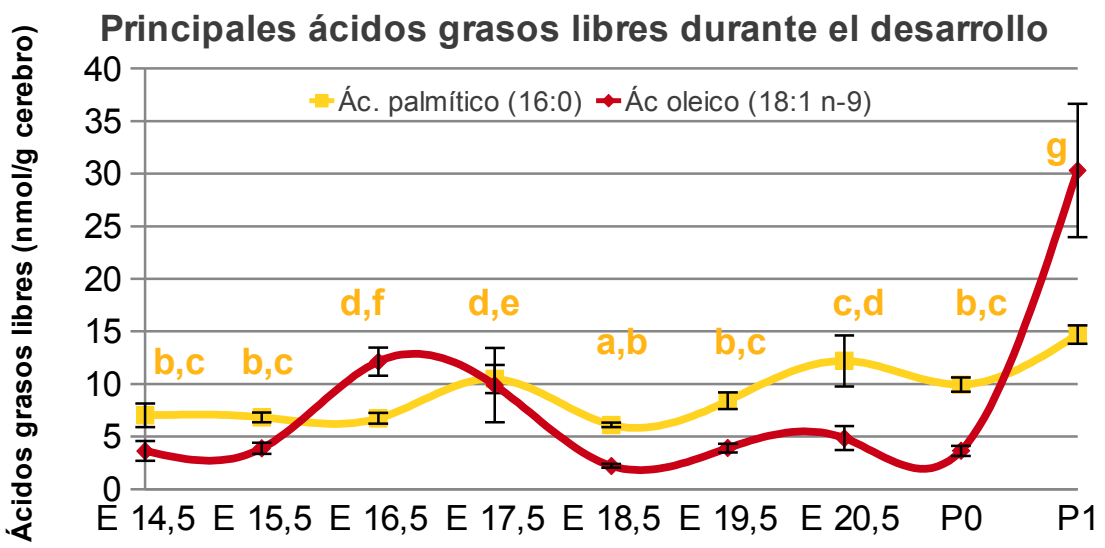

Edad

c)

Relación ác. oleico / ác. palmítico

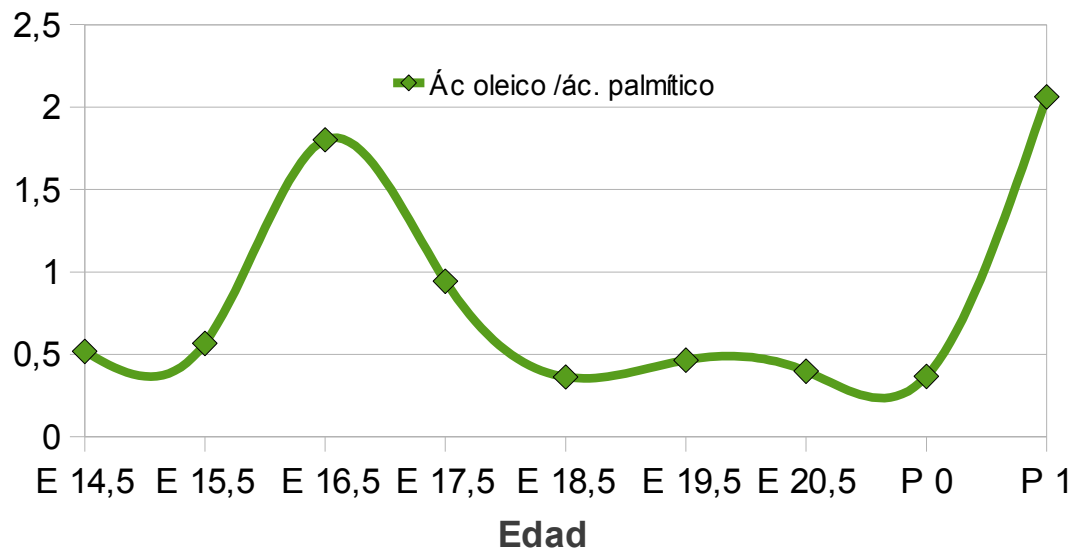

Figura 5.- Análisis de los principales ácidos grasos libres presentes en el cerebro a lo largo del desarrollo. a) Perfiles cromatográficos representativos de los principales ácidos grasos libres presentes en el cerebro de rata en los días P1, E20.5 y E16.5. b) Cuantificación de los ácidos grasos ácido oleico (18:1) y ácido palmítico (16:0). Las áreas de los picos se cuantificaron y los valores se normalizaron en función del estándar interno ácido margárico (17:0). Los resultados se muestran como nmol de ácido graso libre por gramo de cerebro en peso húmedo (nmol/g ww) y representan las medias \pm S.E.M. de al menos tres experimentos independientes. Las diferencias entre los valores se consideraron significativas cuando $p<0,05$. Tras la ANOVA, las muestras se asignaron dentro de grupos homogéneos mediante el test de HSD -Tukey. Los grupos con letras iguales no presentan diferencias significativas. c) Relación de las concentraciones de ácido oleico / ácido palmítico (18:1 n-9/16:0) a lo largo del desarrollo. 


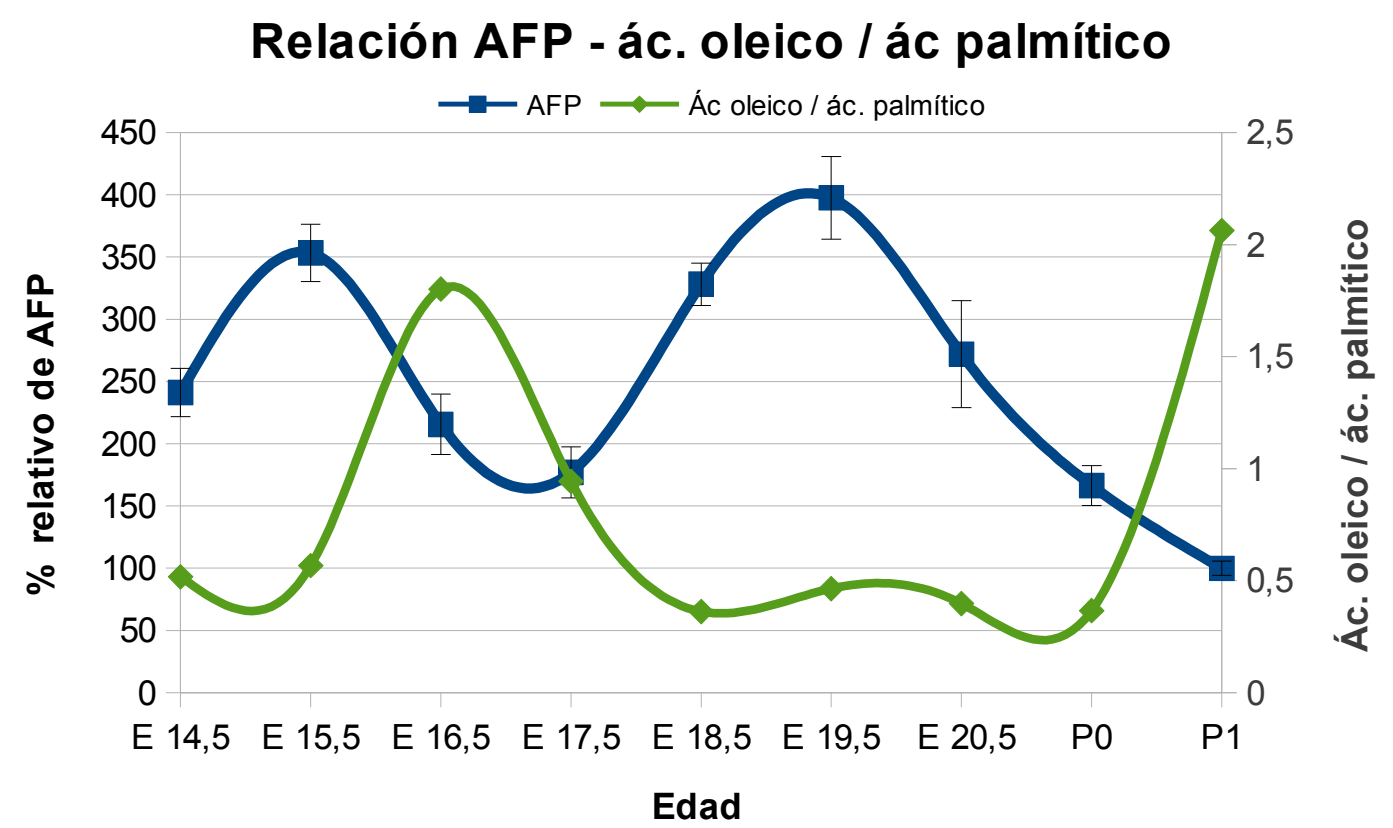

Figura 6.- Relación entre la alfa-fetoproteína y los ácidos grasos libres presentes en el cerebro durante el desarrollo. En esta gráfica se representa la relación entre la AFP conjuntamente cociente entre el ácido oleico y el ácido palmítico. 


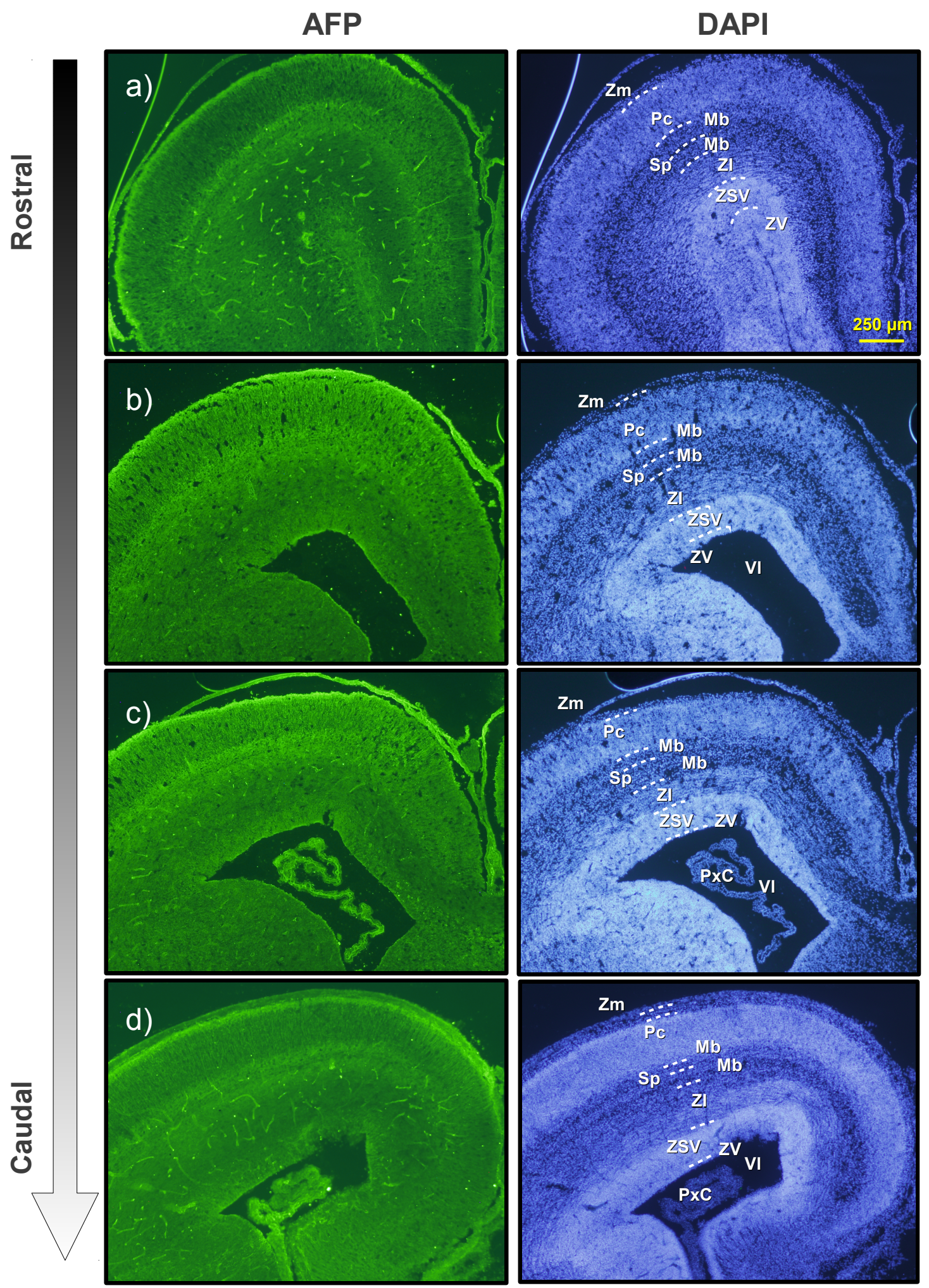

Figura 7.- Distribución de la alfa-fetoproteína a lo largo del eje rostro-caudal el día E19,5 de desarrollo fetal. Los fetos de 19,5 días de gestación se fijaron mediante perfusión intracardíaca y los cerebros se cortaron en criostato en secciones de $10 \mu \mathrm{m}$. Las secciones se incubaron con el anticuerpo policlonal contra AFP y posteriormente con el anticuerpo secundario contra IgG de conejo, conjugado con Alexa-Fluor 488. Por último, los núcleos se tiñeron con DAPI. Abreviaturas: Zm, zona marginal; Pc, placa cortical; Mb, materia blanca, $\mathrm{Sp}$, subplaca; ZI, zona intermedia; ZSV, zona subventricular; ZV, zona ventricular; Pxc, plexo coroideo; VI, ventrículo lateral. 
AFP
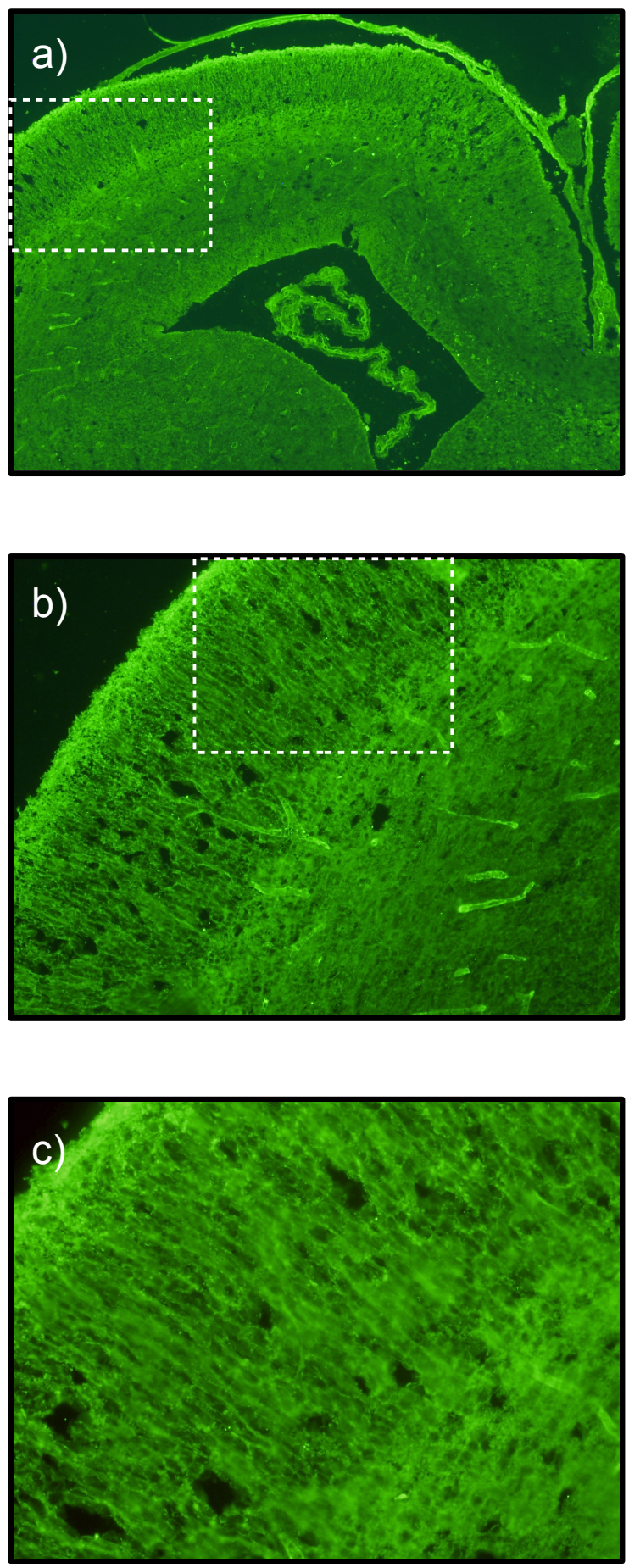

DAPI
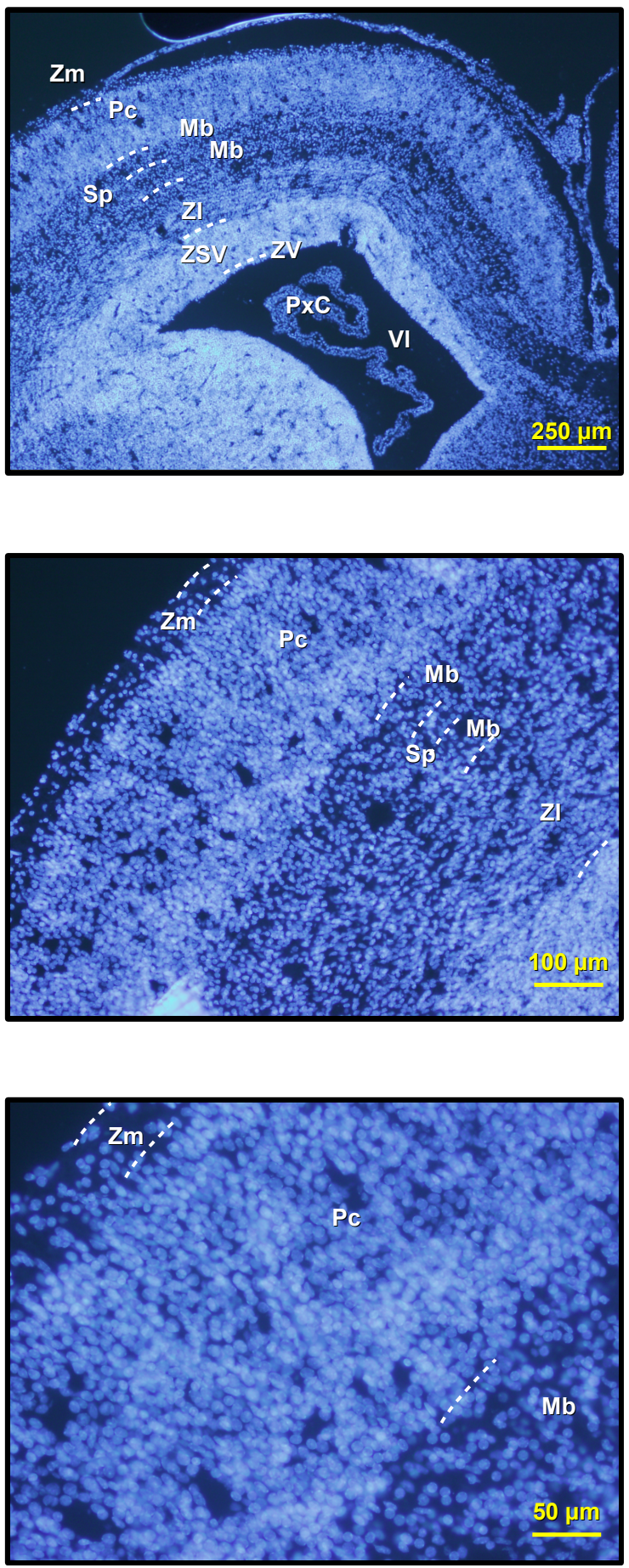

Figura 8.- Detalle de la localización de la alfa-fetoproteína el día E19,5 de desarrollo fetal. Los fetos de 19,5 días de gestación se fijaron mediante perfusión intracardíaca y los cerebros se cortaron en criostato en secciones de $10 \mu \mathrm{m}$. Las secciones se incubaron con el anticuerpo policlonal contra AFP y posteriormente con el anticuerpo secundario contra IgG de conejo, conjugado con Alexa-Fluor 488. Por último, los núcleos se tiñeron con DAPI. Abreviaturas: Zm, zona marginal; Pc, placa cortical; Mb, materia blanca, Sp, subplaca; ZI, zona intermedia; ZSV, zona subventricular; ZV, zona ventricular; Pxc, plexo coroideo; VI, ventrículo lateral. 

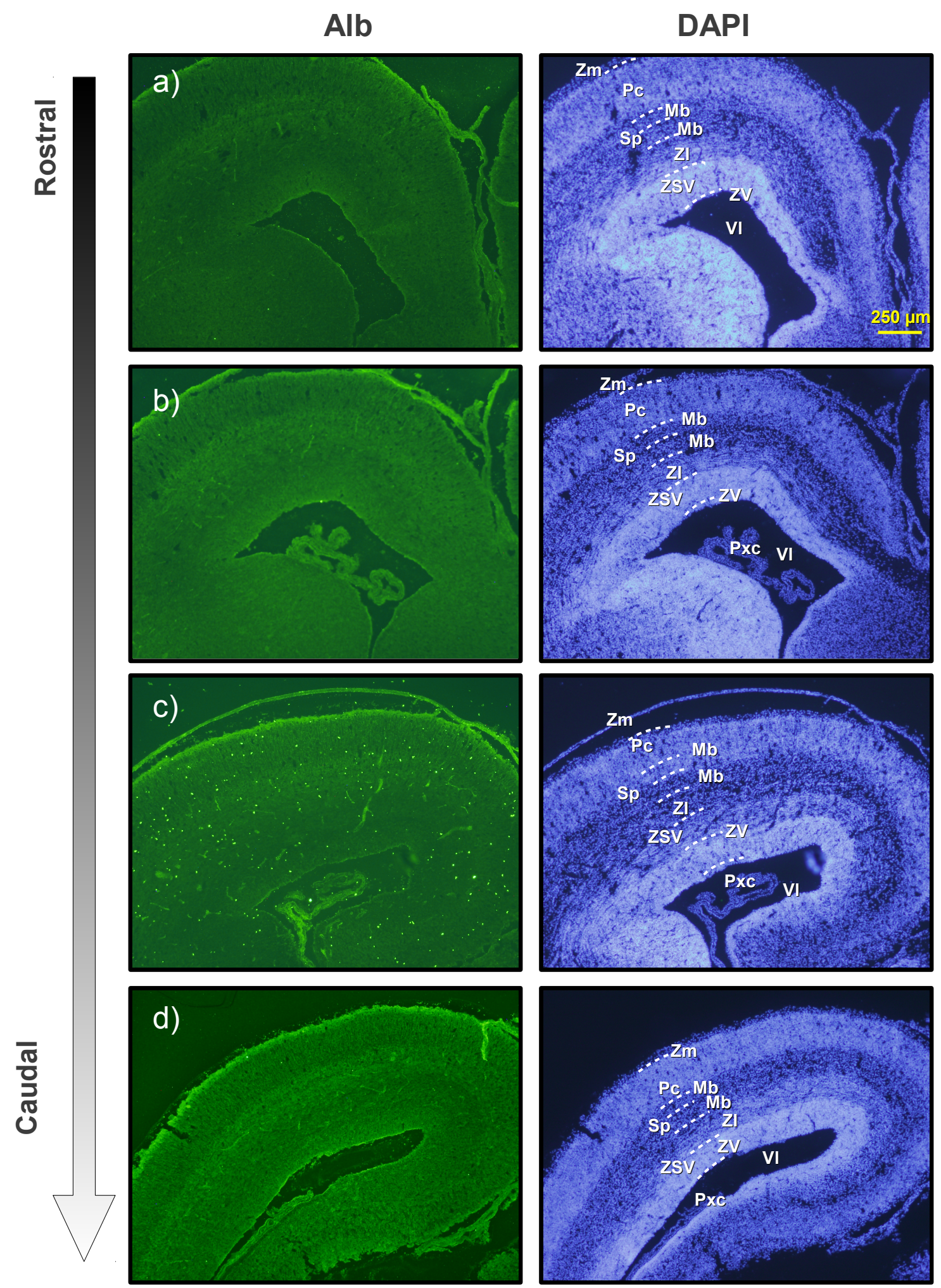

Figura 9.- Distribución de la albúmina a lo largo del eje rostro-caudal en el día E19,5 de desarrollo fe tal. Los fetos de 19,5 días de gestación se fijaron mediante perfusión intracardíaca y los cerebros se cortaron en criostato en secciones de $10 \mu \mathrm{m}$. Las secciones se incubaron con el anticuerpo policlonal contra BSA y posteriormente con el anticuerpo secundario contra IgG de conejo, conjugado con Alexa-Fluor 488. Por último, los núcleos se tiñeron con DAPI. Abreviaturas: Zm, zona marginal; Pc, placa cortical; $\mathrm{Mb}$, materia blanca, $\mathrm{Sp}$, subplaca; ZI, zona intermedia; ZSV, zona subventricular; ZV, zona ventricular; Pxc, plexo coroideo; VI, ventrículo lateral. 
Alb

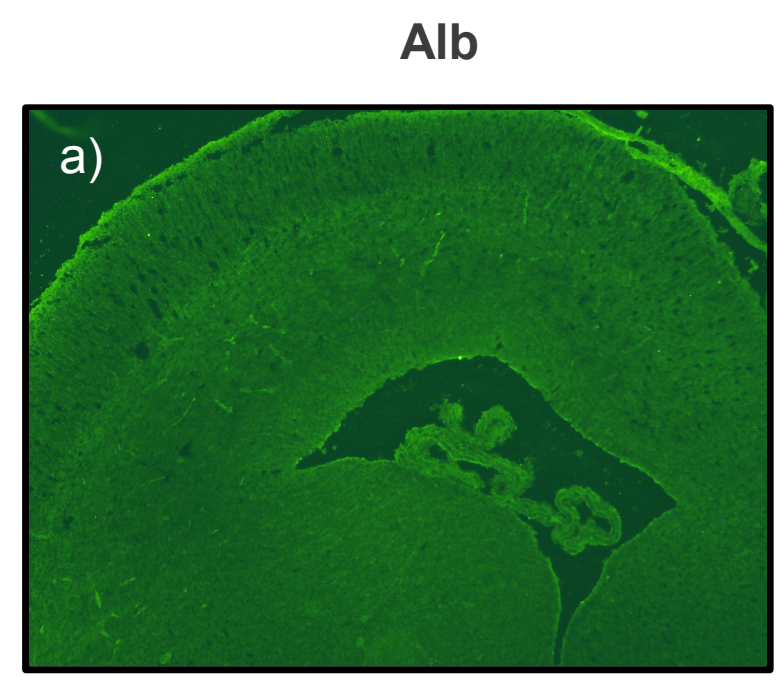

b)
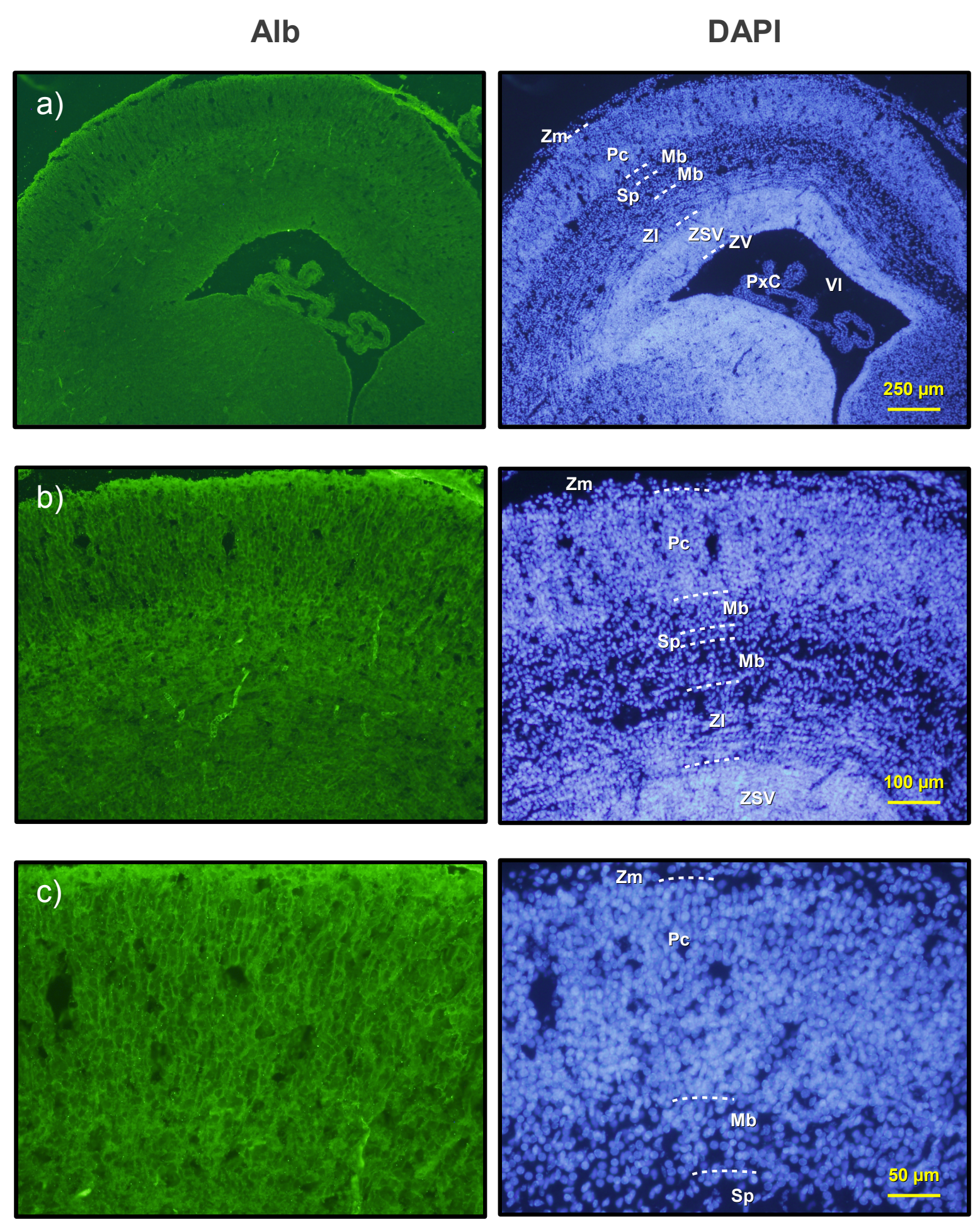

Figura 10.- Detalle de la localización de la albúmina en el día E19,5 de desarrollo fetal. Los fetos de 19,5 días de gestación se fijaron mediante perfusión intracardíaca y los cerebros se cortaron en criostato en secciones de $10 \mu \mathrm{m}$. Las secciones se incubaron con el anticuerpo policlonal contra la BSA y posteriormente con el anticuerpo secundario contra lgG de conejo, conjugado con Alexa-Fluor 488. Por último, los núcleos se tiñeron con DAPI. Abreviaturas: Zm, zona marginal; Pc, placa cortical; Mb, materia blanca, Sp, subplaca; ZI, zona intermedia; ZSV, zona subventricular; ZV, zona ventricular; Pxc, plexo coroideo; VI, ventrículo lateral. 

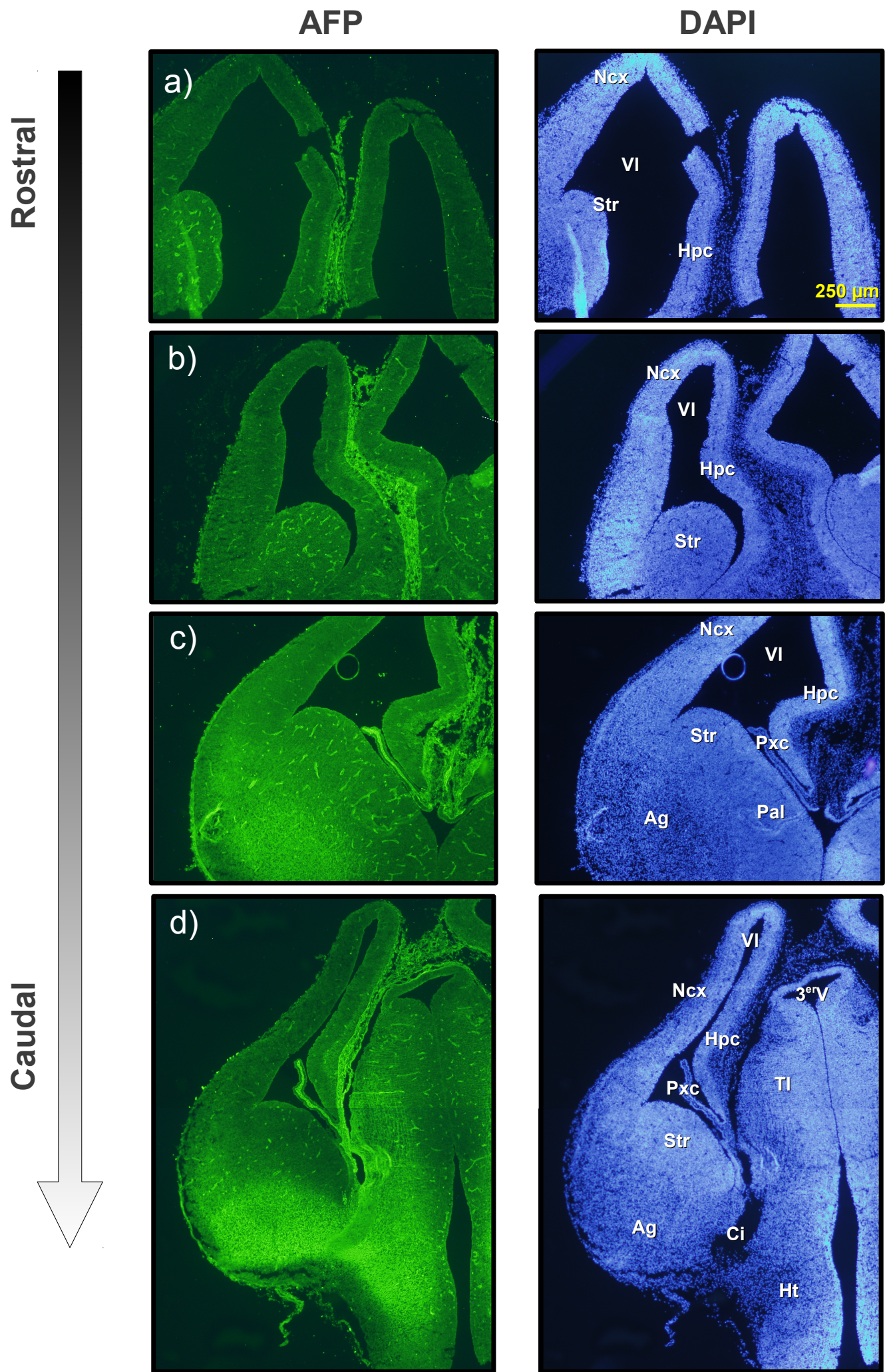

Figura 11.- Distribución de la alfa-fetoproteína a lo largo del eje rostro-caudal en el día E1,5 de desarrollo embrionario. Los embriones de 15,5 días de gestación se fijaron mediante perfusión intracardíaca y los cerebros se cortaron en criostato en secciones de $10 \mu \mathrm{m}$. Las secciones se incubaron con el anticuerpo policlonal contra AFP y posteriormente con el anticuerpo secundario contra IgG de conejo, conjugado con Alexa-Fluor 488. Por último, los núcleos se tiñeron con DAPI. Abreviaturas: Ncx: neocórtex; Pxc, plexo coroideo; VI, ventrículo lateral; 3erv, tercer ventrículo;Str, estriado; Hpc, hipocampo; Ag, amigdala; Pal, Pálido; Ci, Cápsula interna. 
AFP
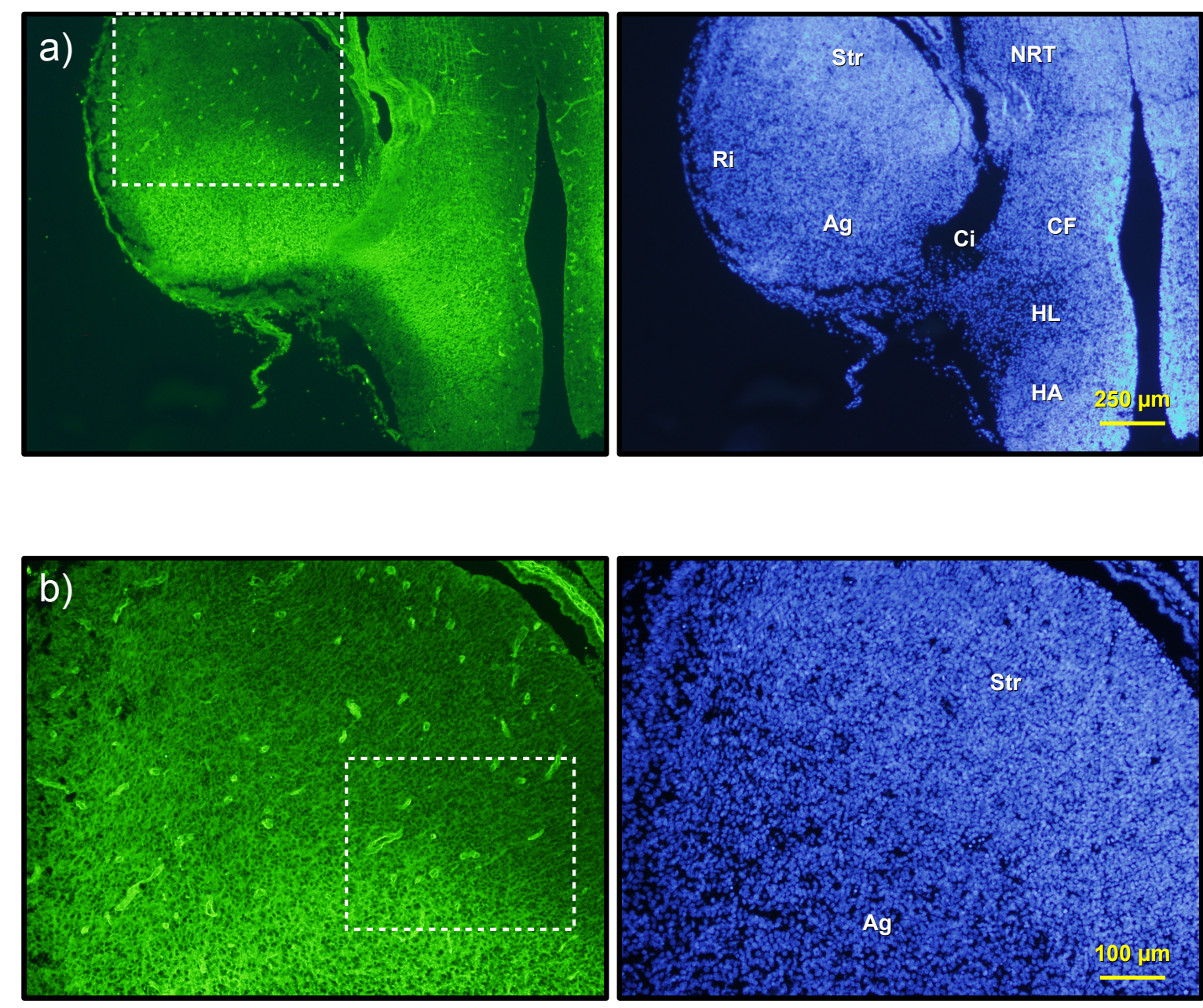

DAPI

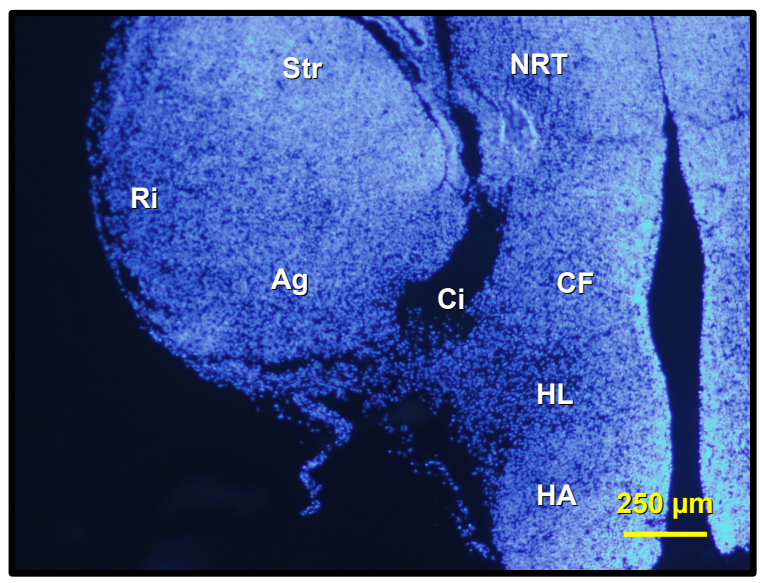

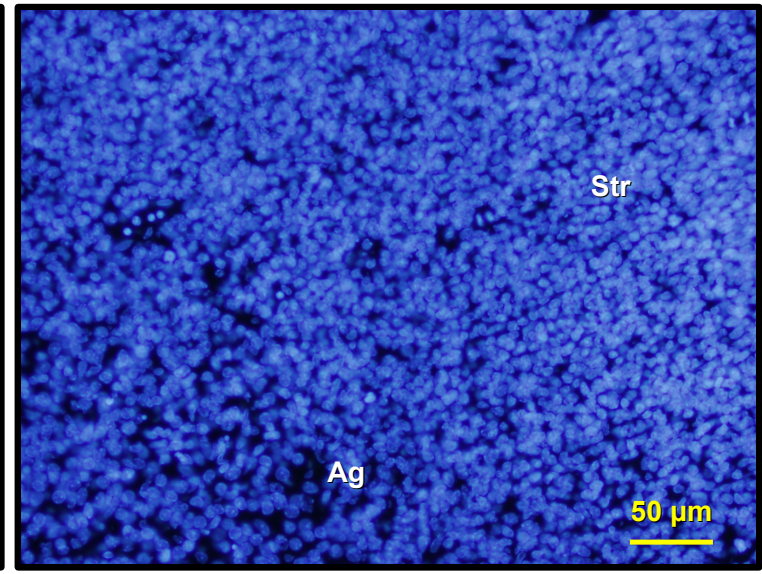

Figura 12.- Detalle de la localización de la alfa-fetoproteína en el día E15,5 de desarrollo embrionario. Los embriones de 15,5 días de gestación se fijaron mediante perfusión intracardíaca y los cerebros se cortaron en criostato en secciones de $10 \mu \mathrm{m}$. Las secciones se incubaron con el anticuerpo policlonal contra AFP y posteriormente con el anticuerpo secundario contra IgG de conejo, conjugado con Alexa-Fluor 488. Por último los núcleos se tiñeron con DAPI. Abreviaturas: NRT, núcleo reticular talámico; CF, campos de Forel; HL, hipotálamo lateral; HA, hipotálamo anterior; Ci, cápsula interna; Str, estriado; Ag, amígdala 
AFP
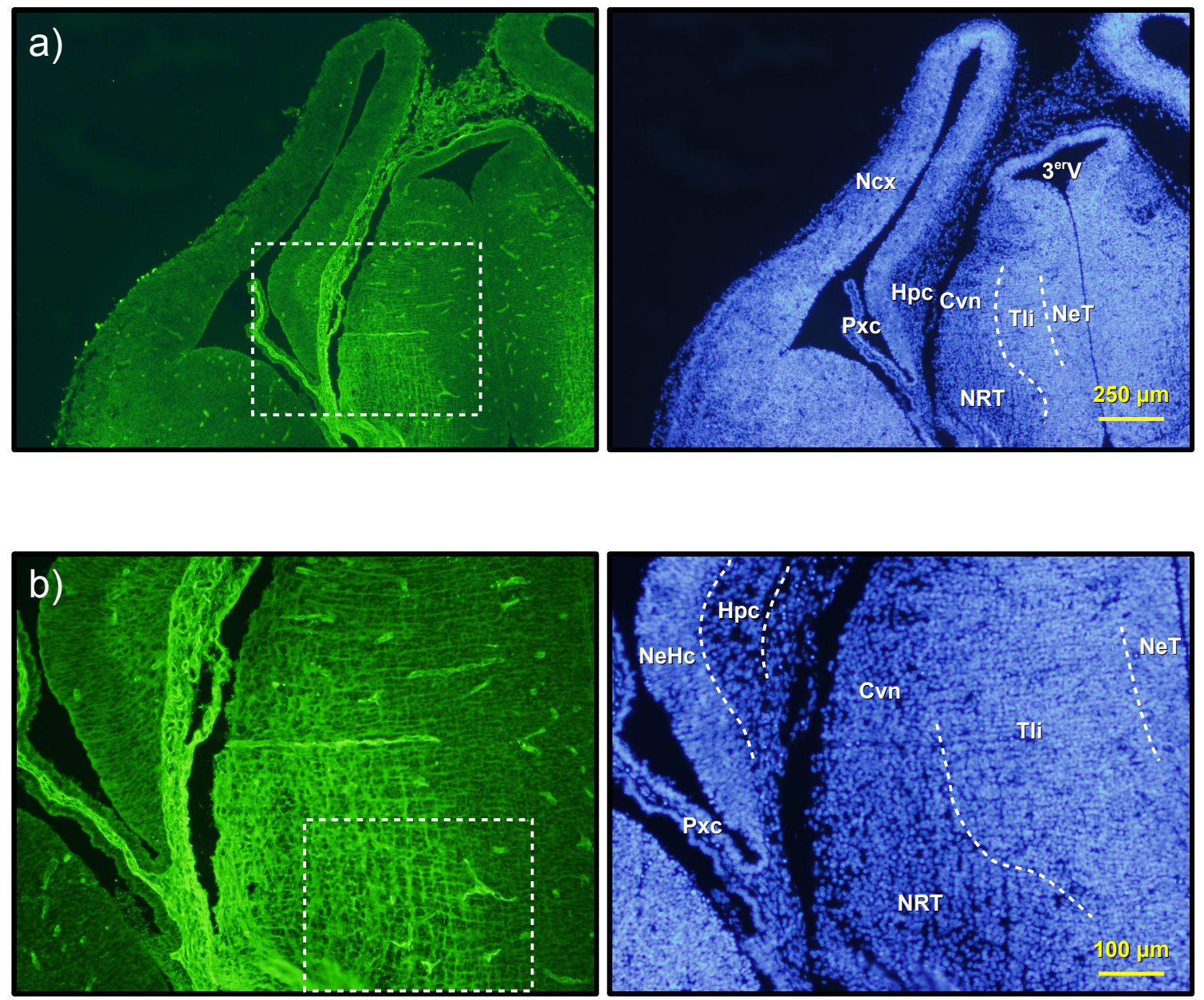

DAPI

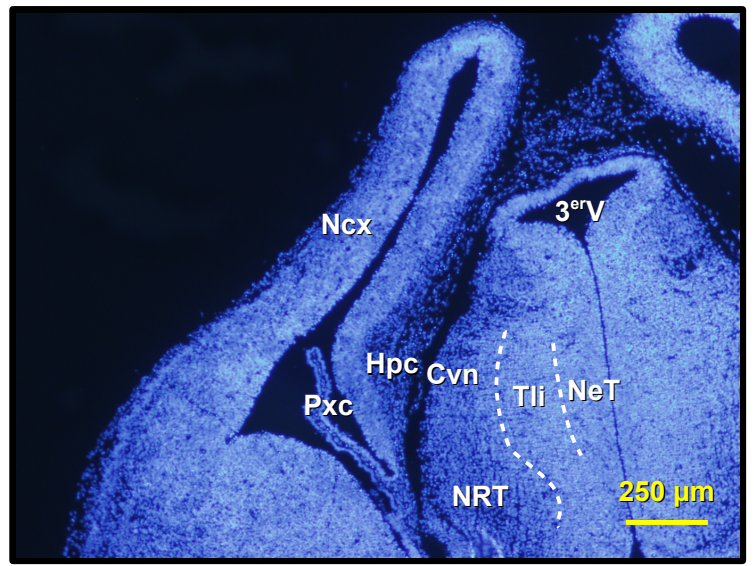

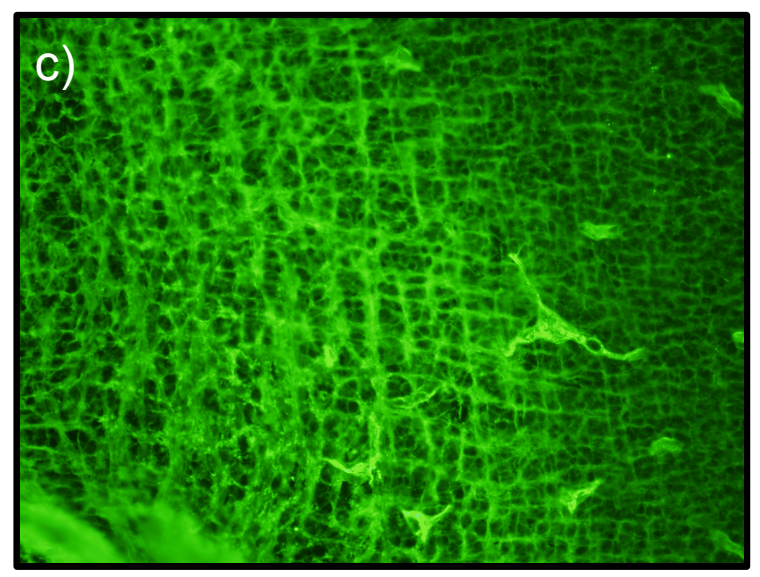

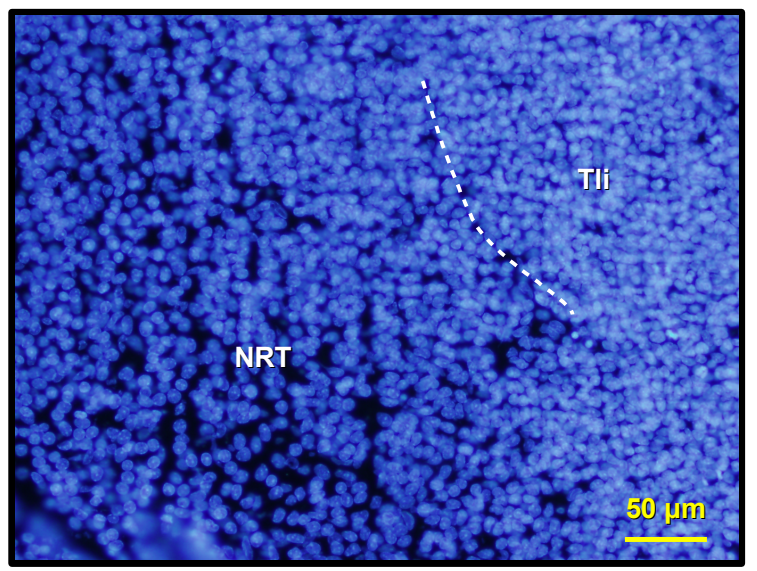

Figura 13.- Detalle de la localización de la alfa-fetoproteína en el día E15,5 de desarrollo embrionario. Los embriones de 15,5 días de gestación se fijaron mediante perfusión intracardíaca y los cerebros se cortaron en criostato en secciones de $10 \mu \mathrm{m}$. Las secciones se incubaron con el anticuerpo policlonal contra AFP y posteriormente con el anticuerpo secundario contra lgG de conejo, conjugado con Alexa-Fluor 488. Por último los núcleos se tiñeron con DAPI. Abreviaturas: Ncx: neocórtex; Pxc, plexo coroideo; 3erv, tercer ventrículo;Str, estriado; Hpc, hipocampo; NeHc, neuroepitelio hipocampal; NeT, neuroepitelio hipotalámico; Tli, tálamo intermedio; Cvn, complejo ventrolateral nuclear; NRT, núcleo reticular talámico. 
Alb
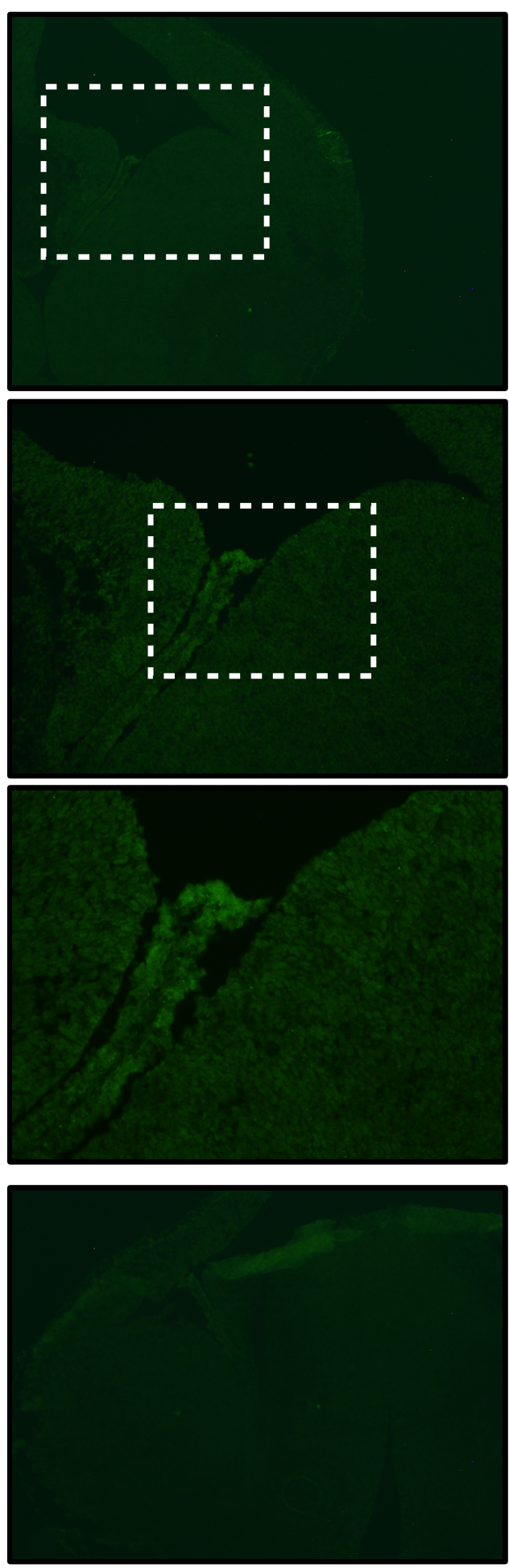

DAPI
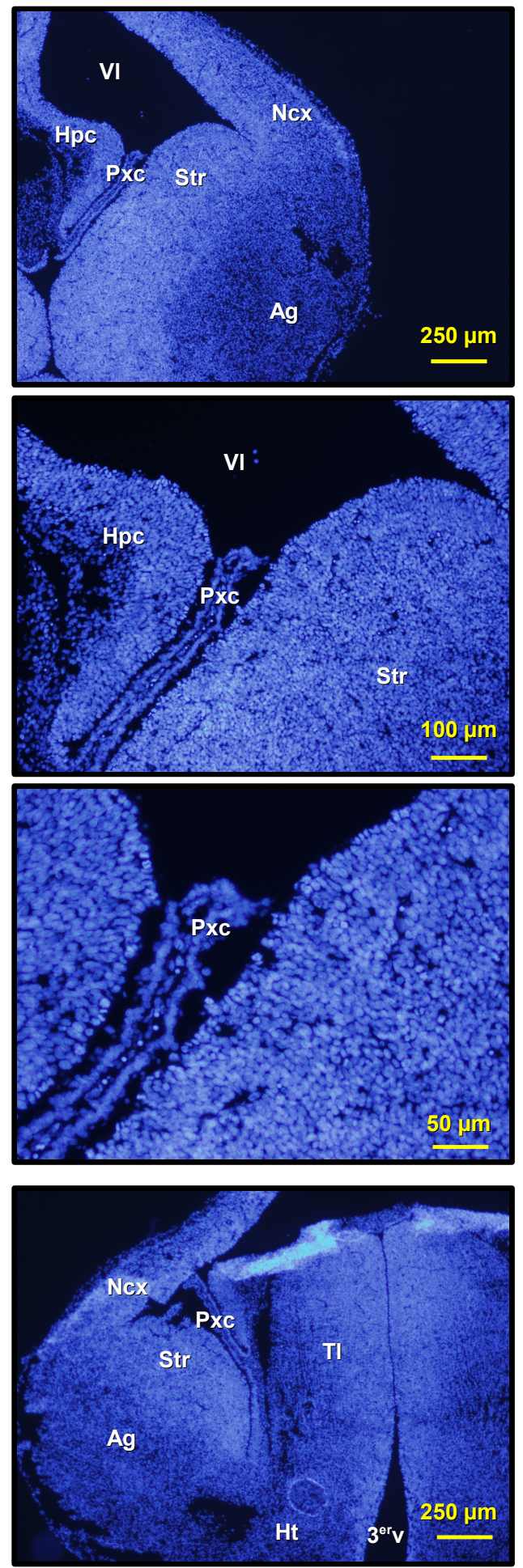

Figura 14.- Distribución de la albúmina en el día E15,5 de desarrollo embrionario. Los embriones de 15,5 días de gestación se fijaron mediante perfusión intracardíaca y los cerebros se cortaron en criostato en secciones de $10 \mu \mathrm{m}$. Las secciones se incubaron con el anticuerpo policlonal contra BSA y posteriormente con el anticuerpo secundario contra IgG de conejo, conjugado con Alexa-Fluor 488. Por último los núcleos se tiñeron con DAPI. Abreviaturas: Ncx: neocórtex; Pxc, plexo coroideo; VI, ventrículo lateral; 3erv, tercer ventrículo;Str, estriado; Hpc, hipocampo; Ag, amígdala; TI tálamo; Ht, Hipotálamo. 


\section{GAP-43}
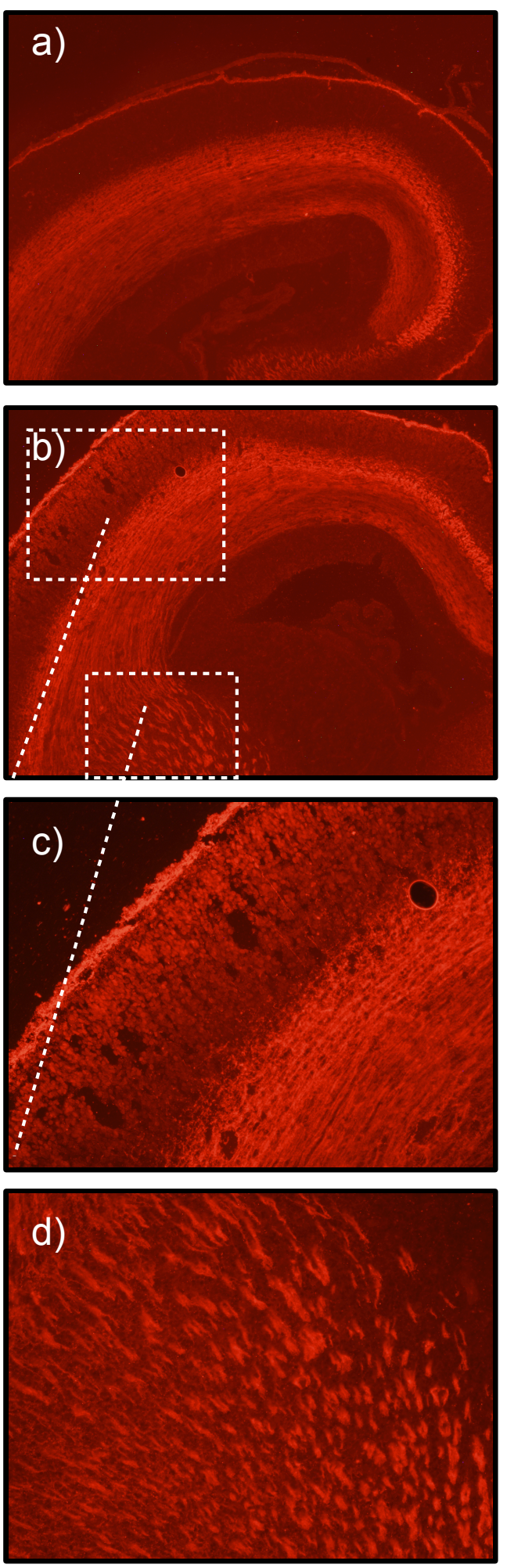

DAPI
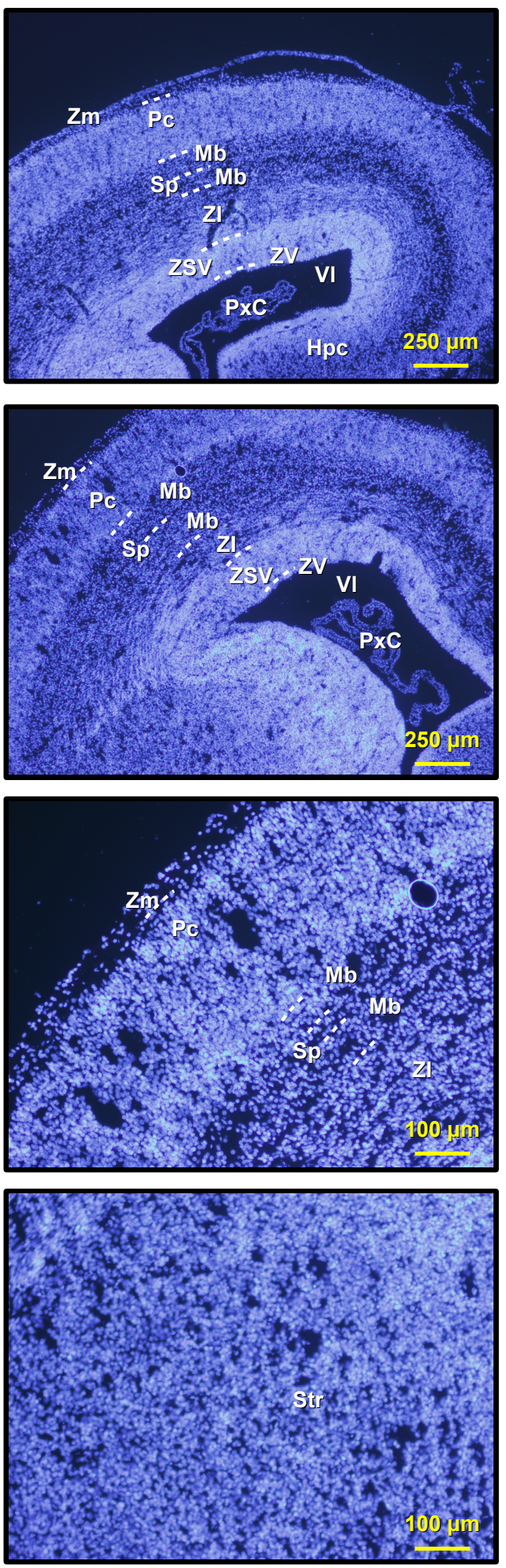

Figura 15.- Distribución de GAP-43 en el día E19,5 de desarrollo fetal. Los fetos de 19,5 días de gestación se fijaron mediante perfusión intracardíaca y los cerebros se cortaron en criostato en secciones de 10 $\mu \mathrm{m}$. Las secciones se incubaron con el anticuerpo monoclonal contra GAP-43 y posteriormente con el anticuerpo secundario contra IgG de conejo, conjugado con Alexa-Fluor 594. Por último los núcleos se tiñeron con DAPI. Abreviaturas: Zm, zona marginal; Pc, placa cortical; Mb, materia blanca, Sp, subplaca; ZI, zona intermedia; ZSV, zona subventricular; ZV, zona ventricular; Pxc, plexo coroideo; VI, ventrículo lateral. 
GAP-43
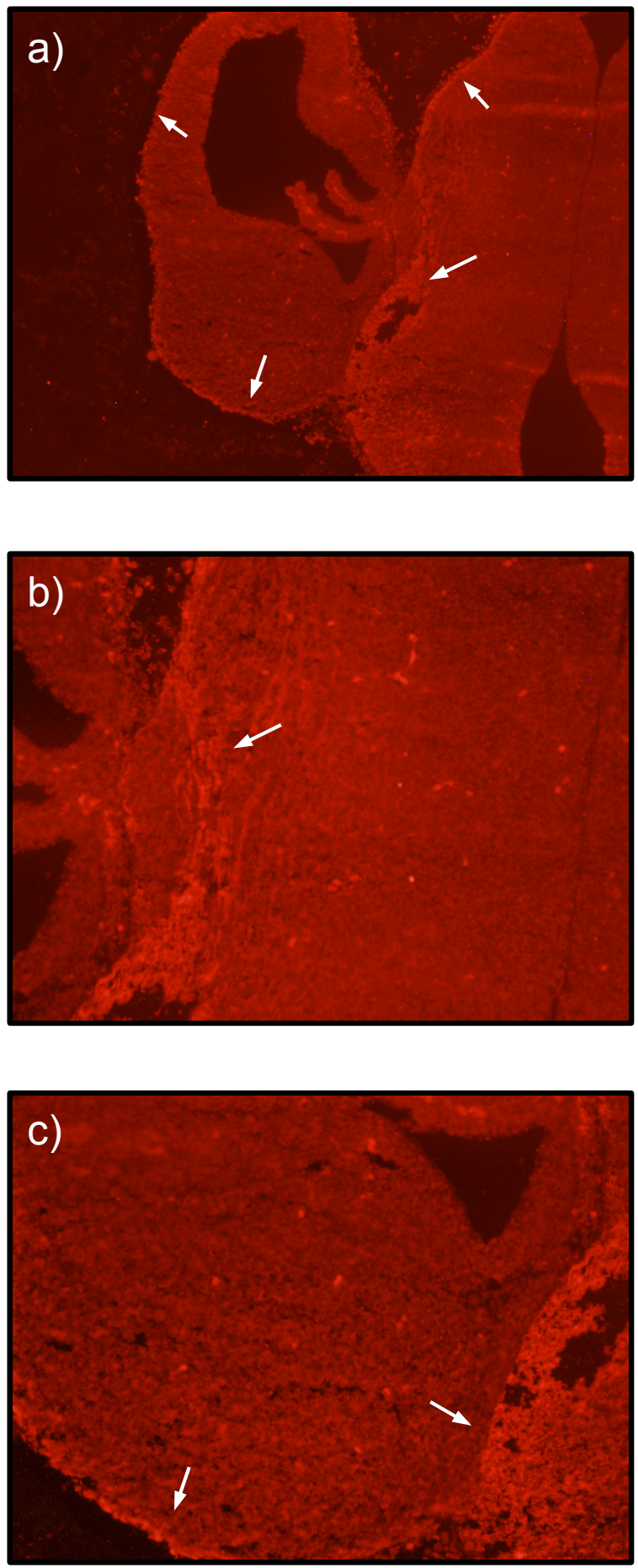

DAPI
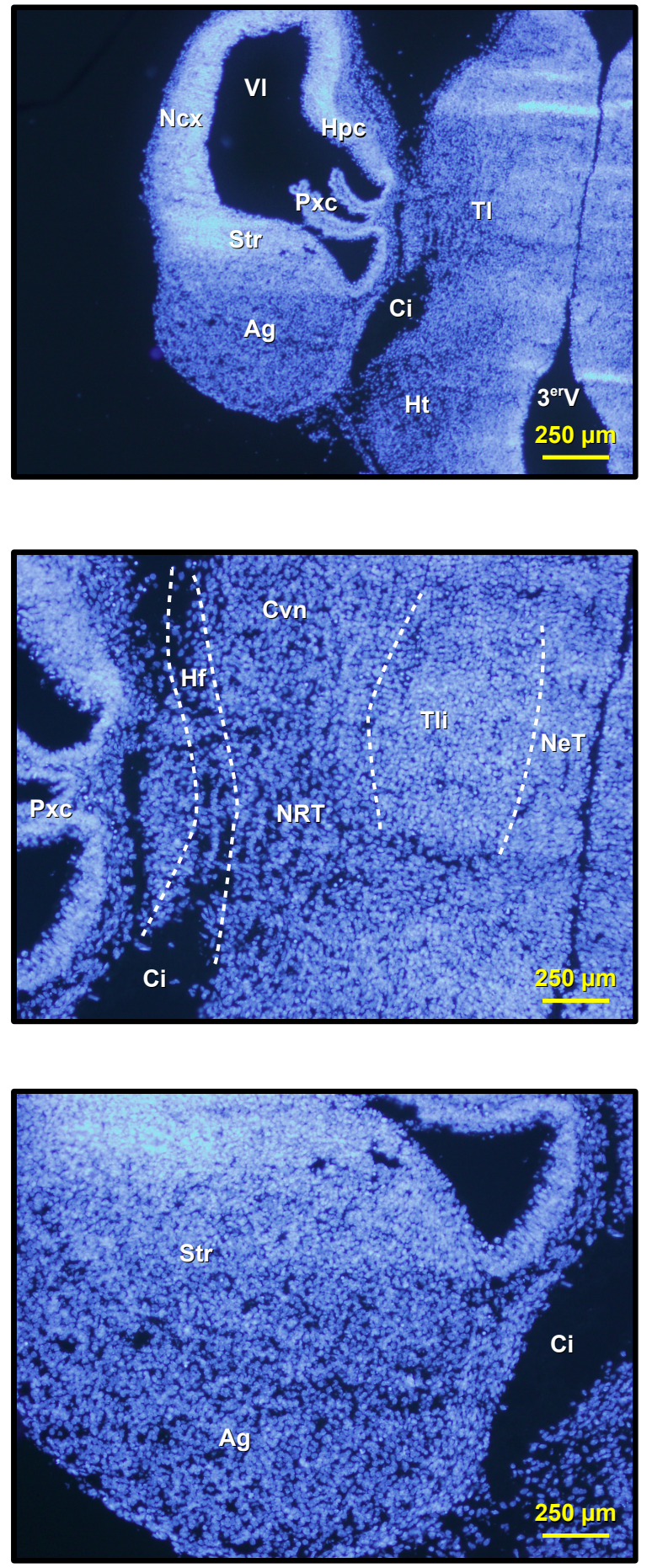

Figura 16.- Distribución de GAP-43 en el día E15,5 de desarrollo fetal. Los fetos de 15,5 días de gestación se fijaron mediante perfusión intracardíaca y los cerebros se cortaron en criostato en secciones de 10 $\mu \mathrm{m}$. Las secciones se incubaron con el anticuerpo monoclonal contra GAP-43 y posteriormente con el anticuerpo secundario contra IgG de conejo, conjugado con Alexa-Fluor 594. Por último los núcleos se tiñeron con DAPI. Por último los núcleos se tiñeron con DAPI. Abreviaturas: Ncx: neocórtex; Pxc, plexo coroideo; 3erv, tercer ventrículo;Str, estriado; Hpc, hipocampo; NeHc, neuroepitelio hipocampal; NeT, neuroepitelio hipotalámico; Tli, tálamo intermedio; Cvn, complejo ventrolateral nuclear; $\mathrm{Ci}$, capsula interna; Hf, haces de fibras; NRT, núcleo reticular talámico. 


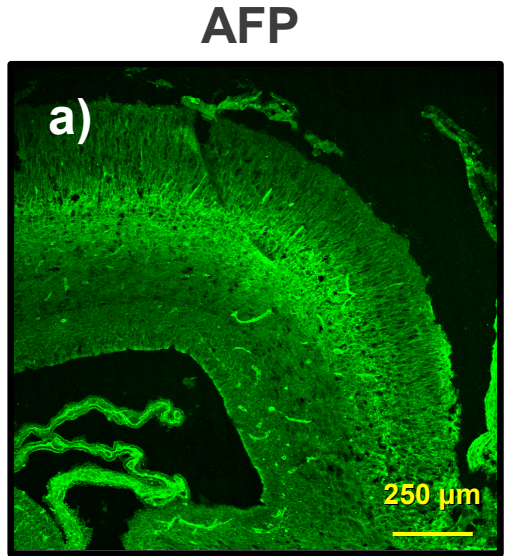

AFP
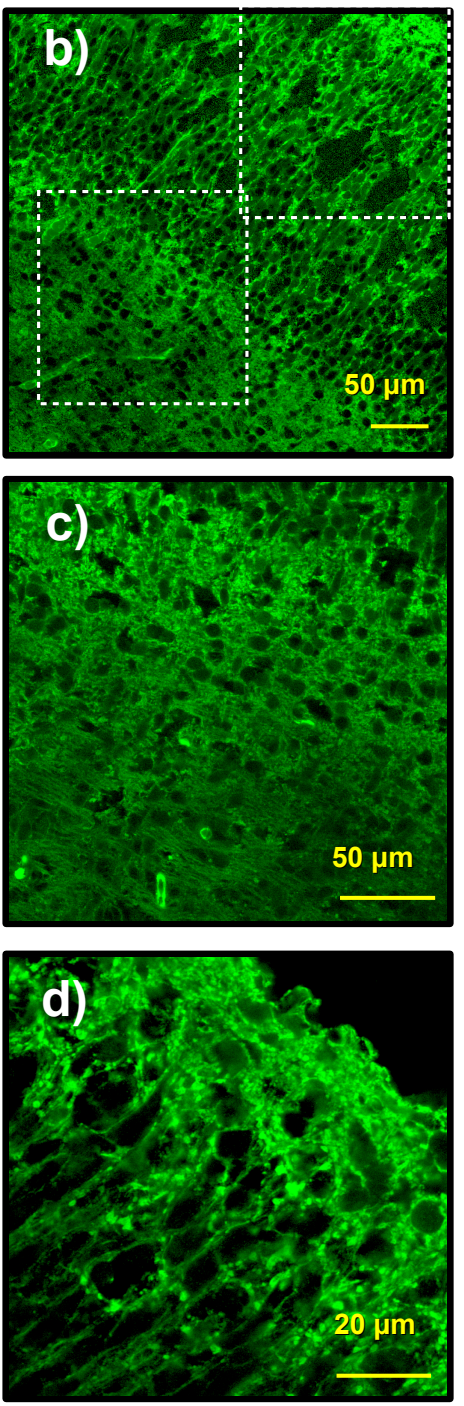

GAP-43

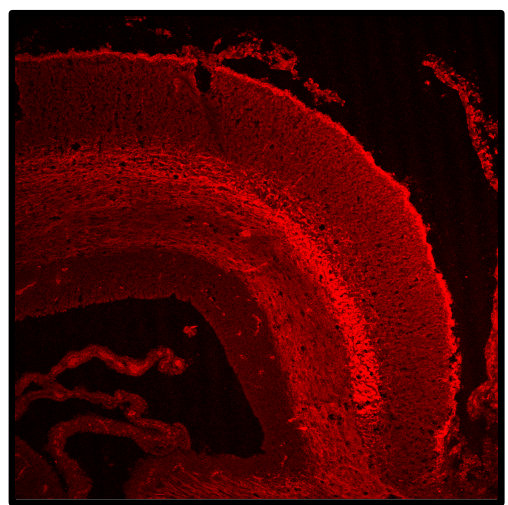

GAP-43
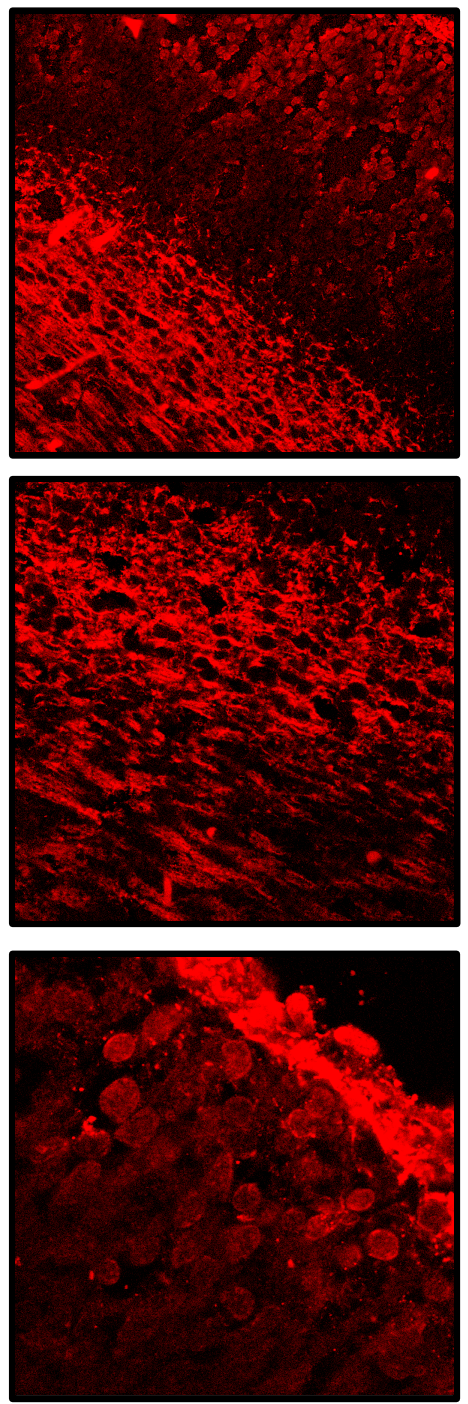

Fusión

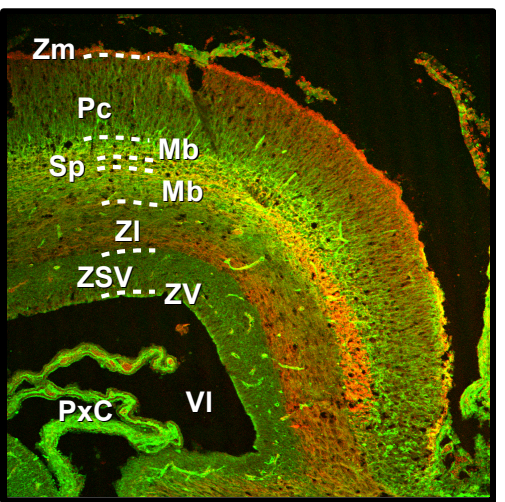

Fusión
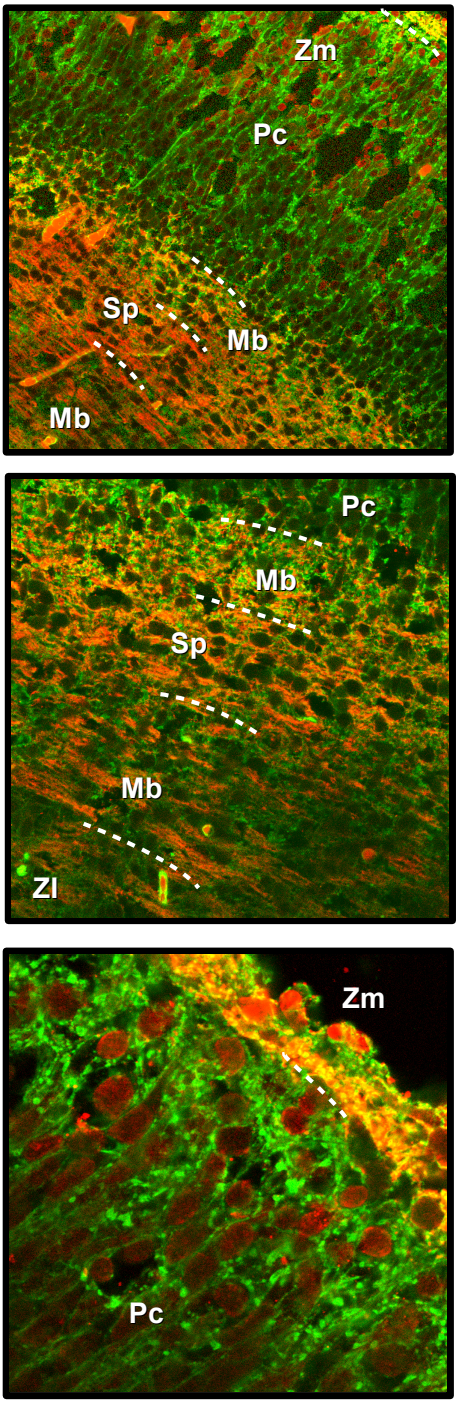

Figura 17.- Doble inmunohistoquímica confocal contra AFP y GAP-43 en el día E19,5 de desarrollo embrionario. Los fetos de 19,5 días de gestación se fijaron mediante perfusión intracardíaca y los cerebros se cortaron en criostato en secciones de $10 \mu \mathrm{m}$. Las secciones se incubaron en primer lugar con el anticuerpo policlonal contra AFP y el anticuerpo secundario con la IgG de conejo, conjugado con Alexa-Fluor 488 y posteriormente con el anticuerpo monoclonal contra GAP-43 y el anticuerpo secundario contra IgG de ratón conjugado con Alexa-Fluor 594. Abreviaturas: Zm, zona marginal; Pc, placa cortical; Mb, materia blanca, Sp, subplaca; ZI, zona intermedia; ZSV, zona subventricular; ZV, zona ventricular; Pxc, plexo coroideo; VI, ventrículo lateral. 

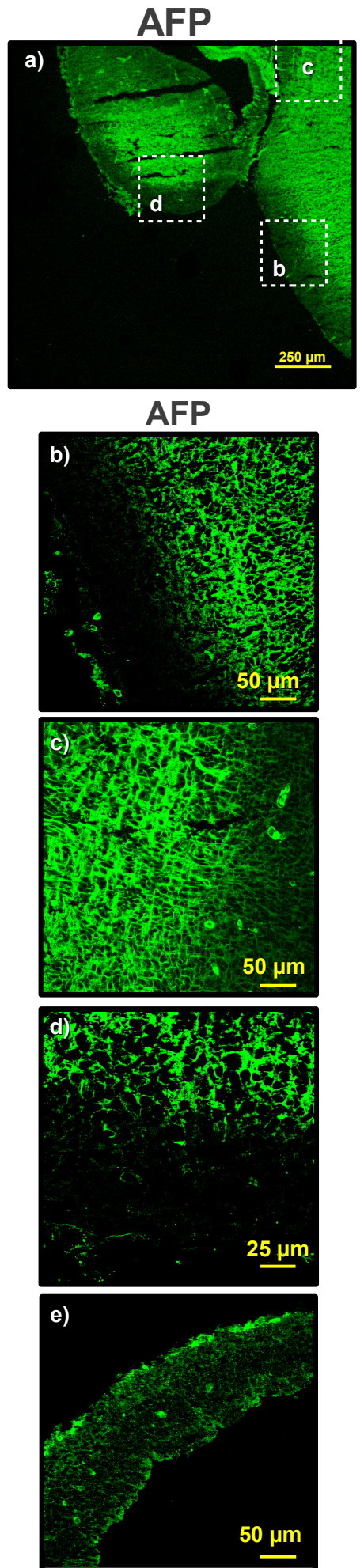

GAP-43

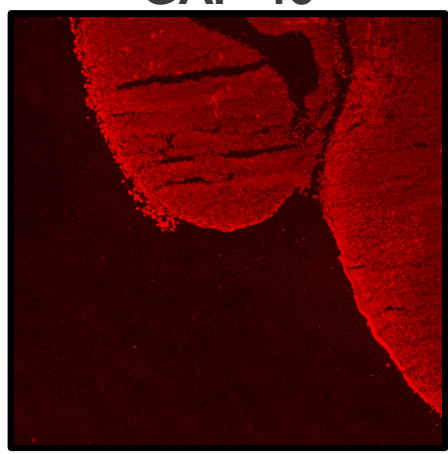

GAP-43
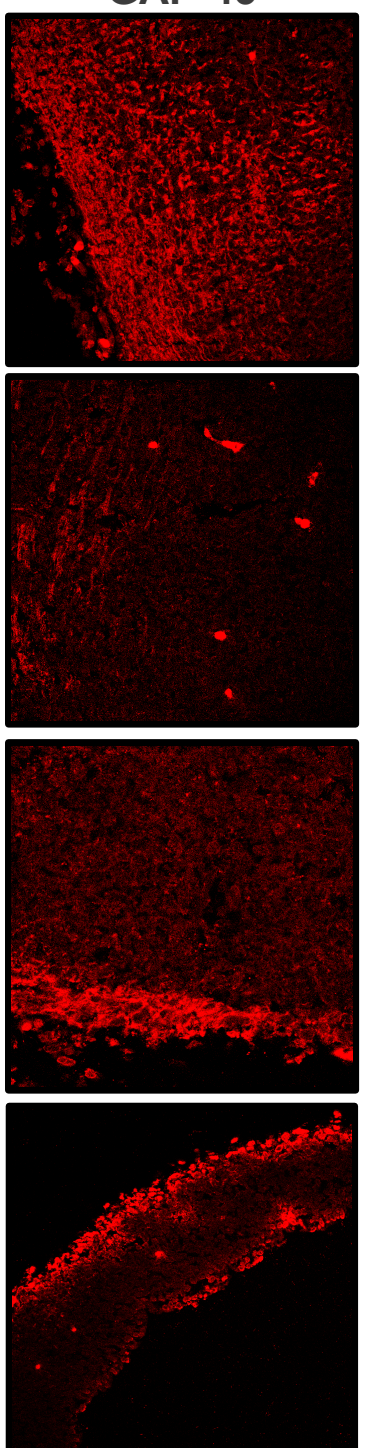

Fusión

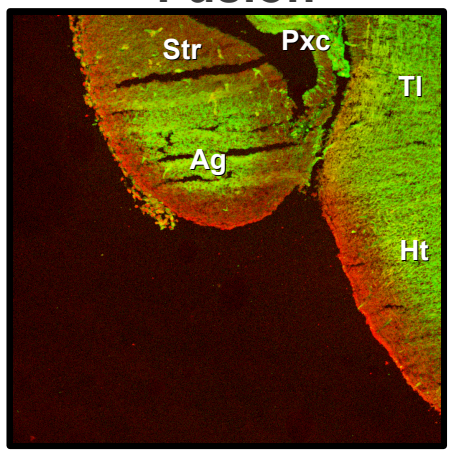

Fusión
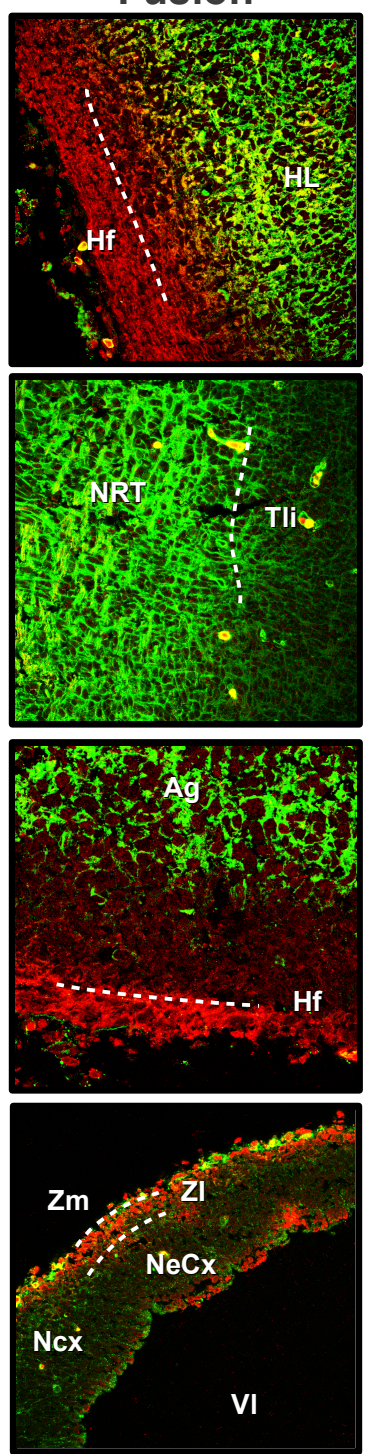

Figura 18.- Doble inmunohistoquímica confocal contra AFP y GAP-43 en el día E15,5 de desarrollo embrionario. Los embriones de 15,5 días de gestación se fijaron mediante perfusión intracardíaca y los cerebros se cortaron en criostato en secciones de $10 \mu \mathrm{m}$. Las secciones se incubaron en primer lugar con el anticuerpo policlonal contra AFP y el anticuerpo secundario contra la lgG de conejo, conjugado con Alexa Fluor 488 y posteriormente con el anticuerpo monoclonal contra GAP-43 y el anticuerpo secundario contra IgG de ratón conjugado con Alexa Fluor 594. Abreviaturas: Ht, hipotálamo; NRT, núcleo reticular talámico; HL, hipotálamo lateral; Hf, haces de fibras; Tli, tálamo intermedio; Cvn, complejo ventrolateral nuclear; Zm, zona marginal; ZI, zona intermedia; Ncx, neocórtex; NeCx, neuroepitelio neocortical; VI, ventrículo lateral. 
a)

AFP

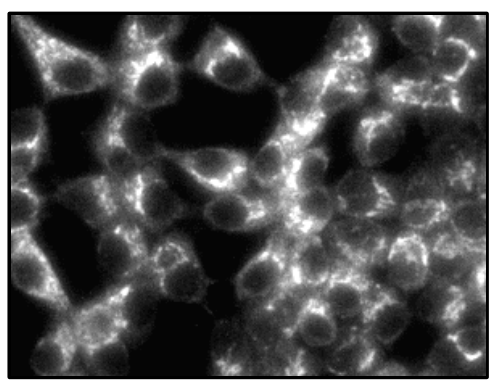

DAPI

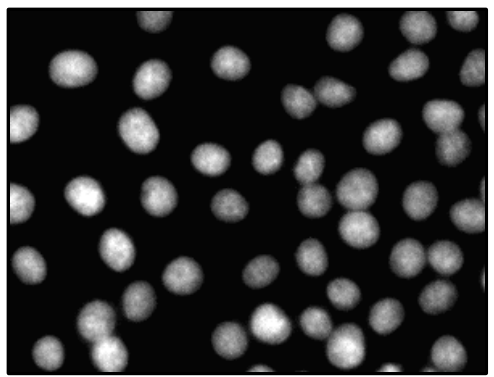

Fusión

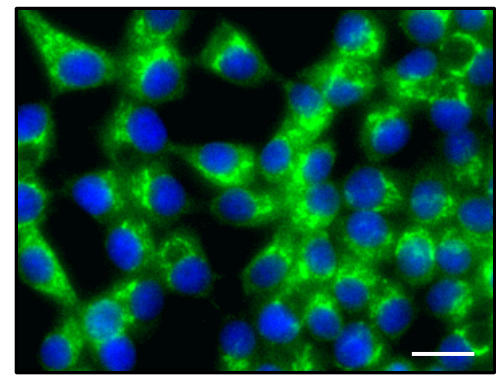

b)
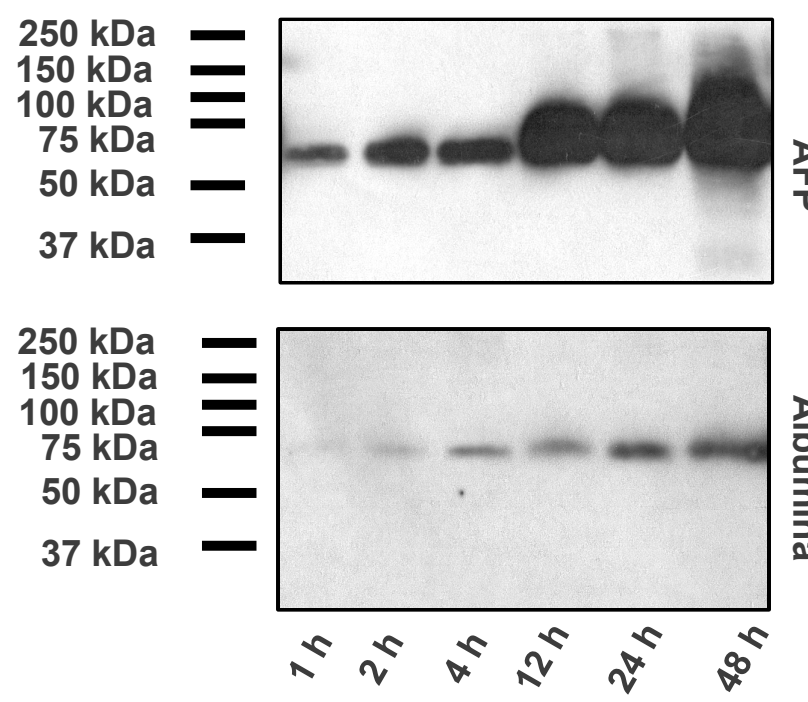

c)

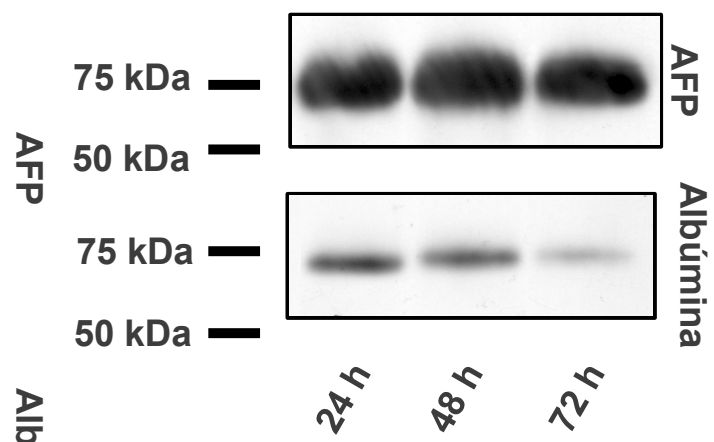

Figura 19.- Producción de AFP por la línea celular de hepatoma de rata McAR-H7777. a) Inmunocitoquímica contra AFP en la línea celular McA-RH7777 (rat Hepatoma, Morris Hepatoma 7777 CRL-1601) tras 8 resiembras. Las células fueron cultivadas en DMEM suplementado con suero fetal inactivado al $10 \%$. Cuando las células alcanzaron aproximadamente el $75 \%$ de confluencia se retiró el suero durante 12 horas. b) El medio de estas células se recogió, filtró y congeló a $-80^{\circ} \mathrm{C}$ para su posterior uso. El Western Blot muestra la presencia de AFP y albúmina acumuladas en el medio de cultivo de las células de hepatoma, a diferentes tiempos. c) EI DMEM se recogió a las 24 horas, se renovó y se analizó por intervalos de 24 horas hasta las 72 horas. El Western-blot muestra la presencia de AFP y albúmina en el medio de cultivo de las células de hepatoma, recogido a intervalos de 24 horas. 


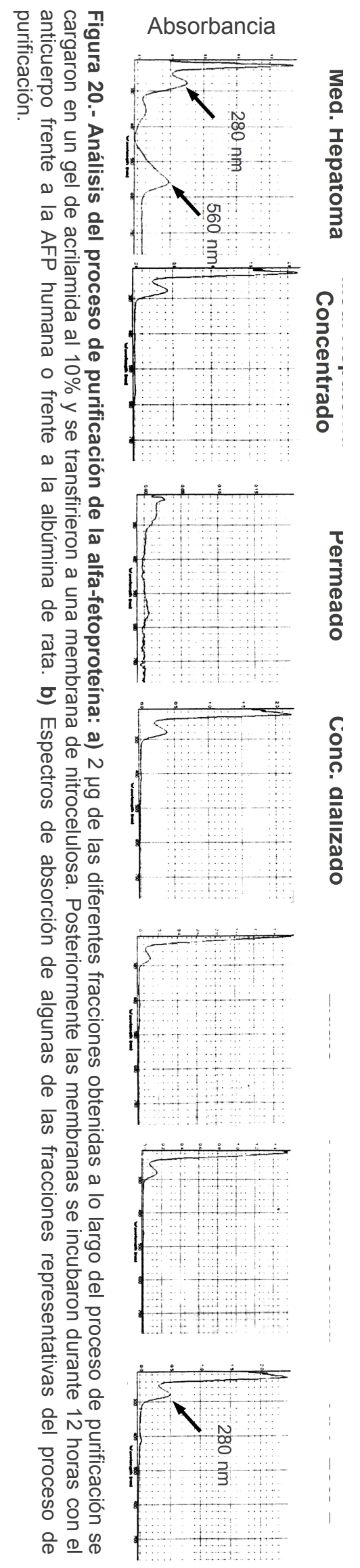

巨
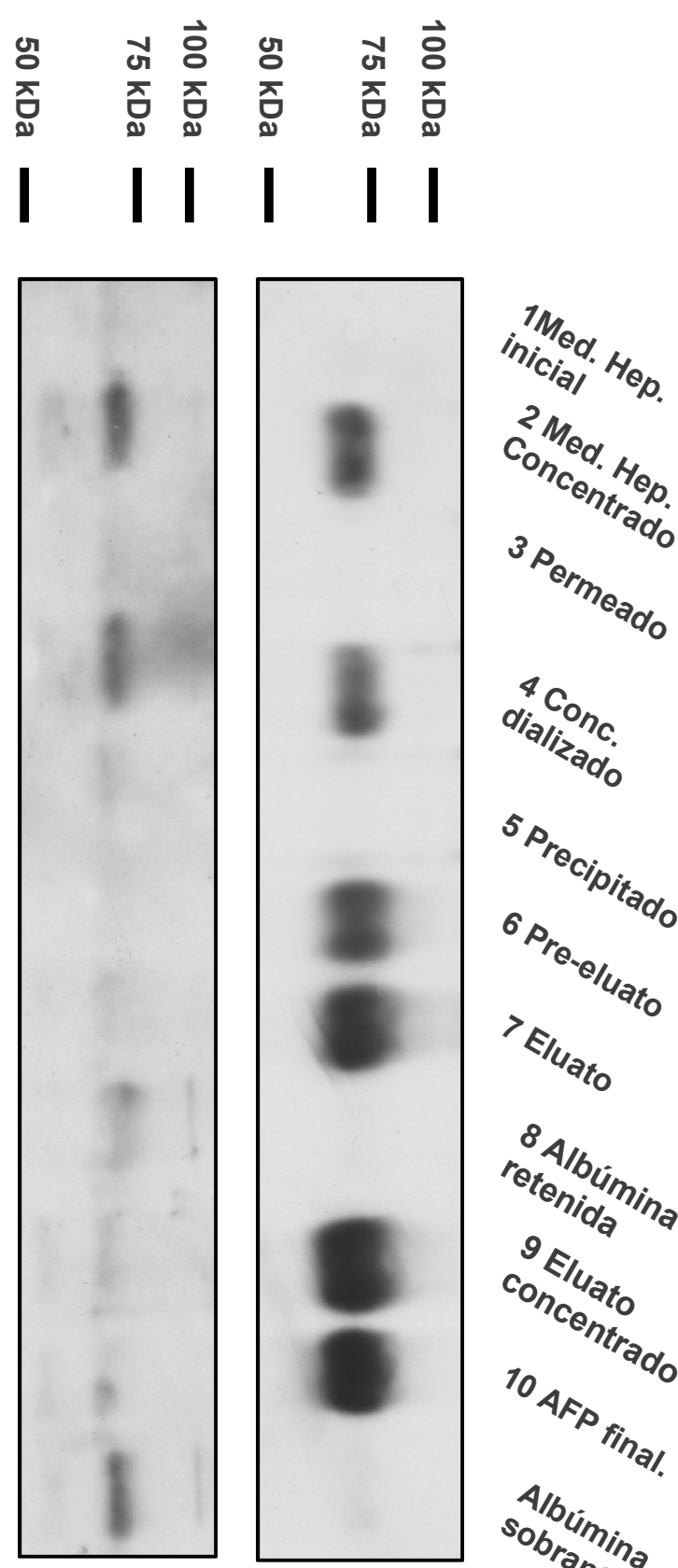

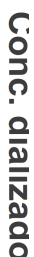

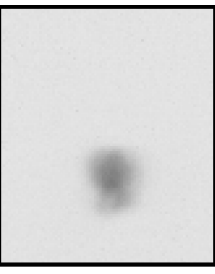

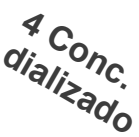

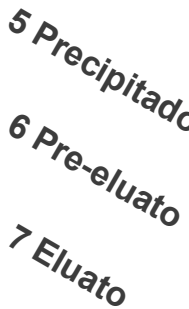

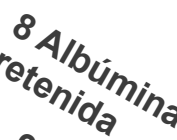

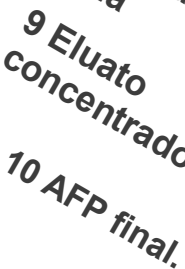

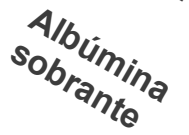

Albúmina Alfa-fetoproteína

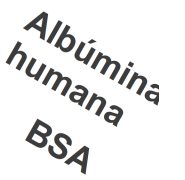



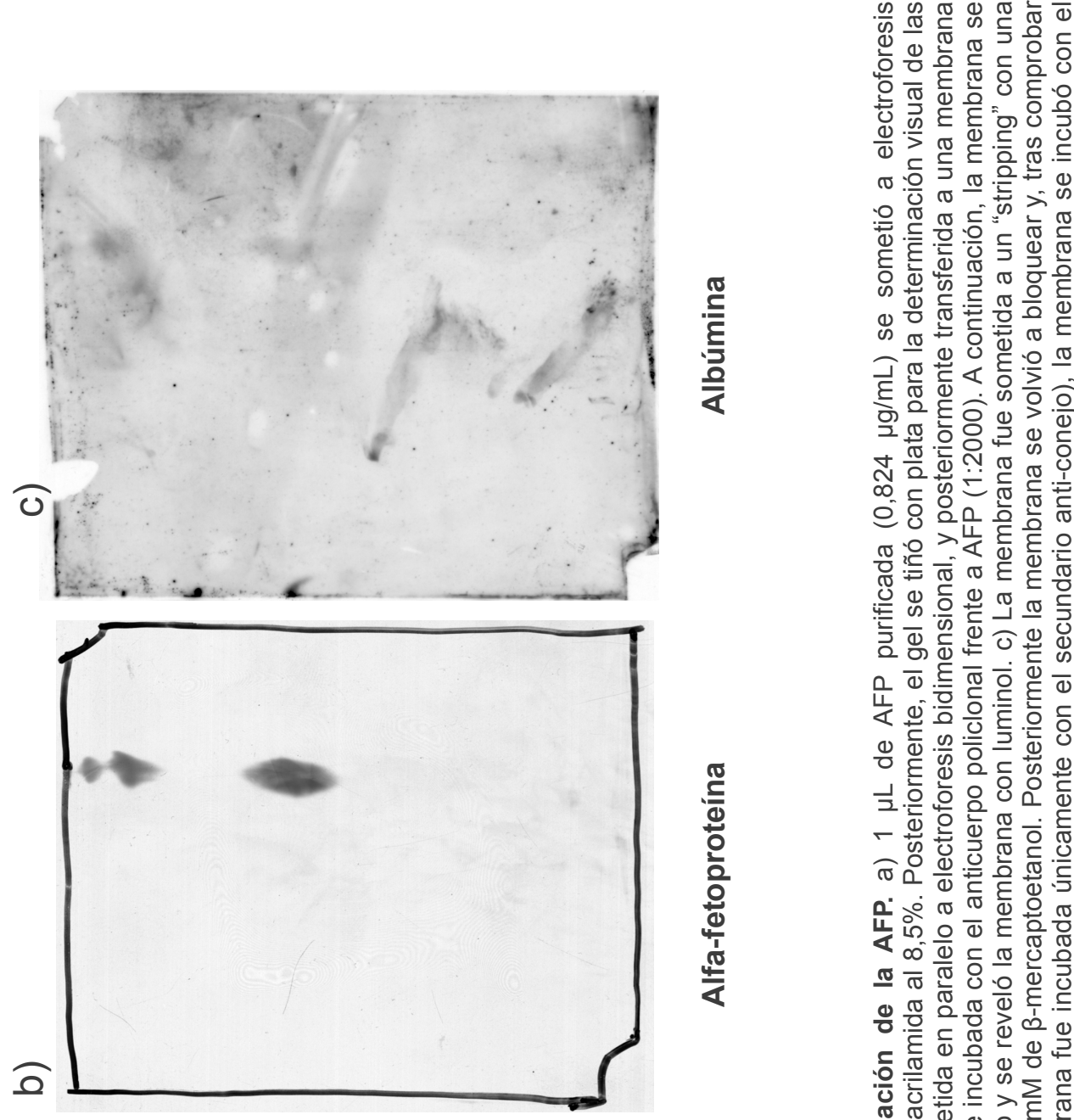

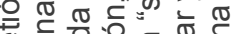

$\varepsilon$

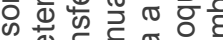
क

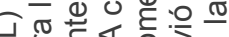
है

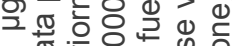

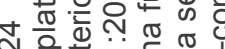
$0,0=\frac{0}{0}$

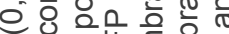

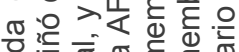
ठ त $\approx$ ह

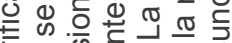

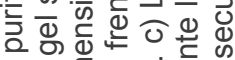

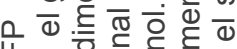

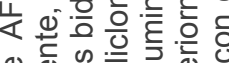
ه

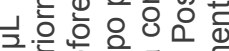

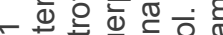
สิ 0.0 叮

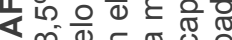

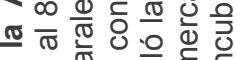
응 중 증 $\frac{\pi}{0}$

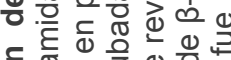
은 준 중 क

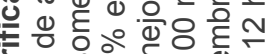

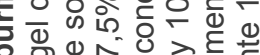
匹

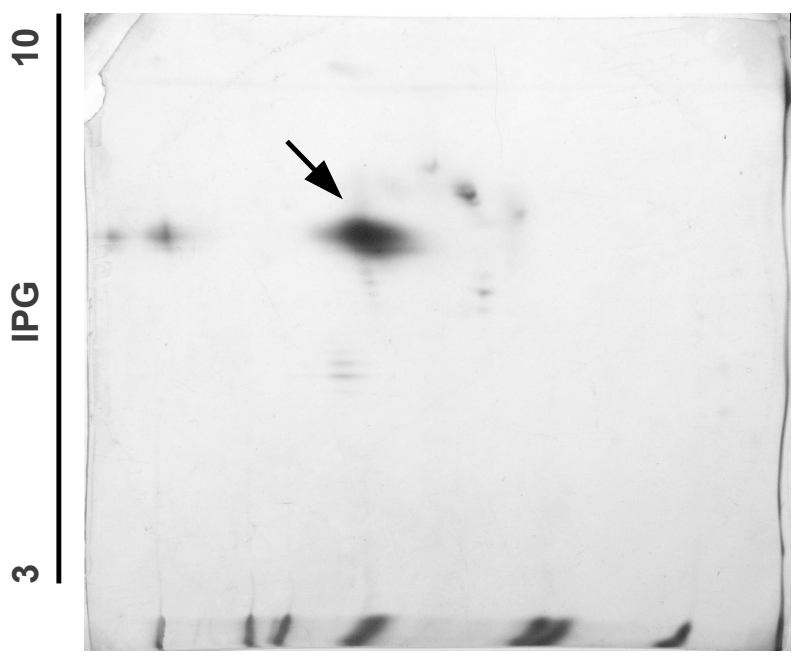

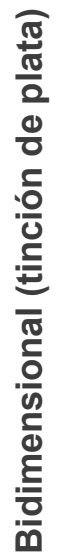
응 응 흥 ․ㅜㅇ은 동음흥 응 눈 음 要

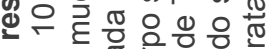

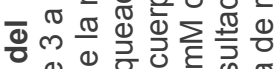

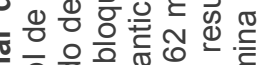

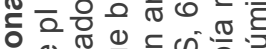

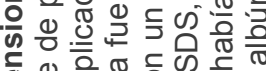

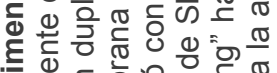

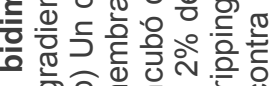

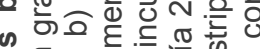

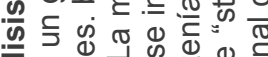

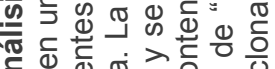

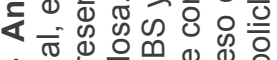

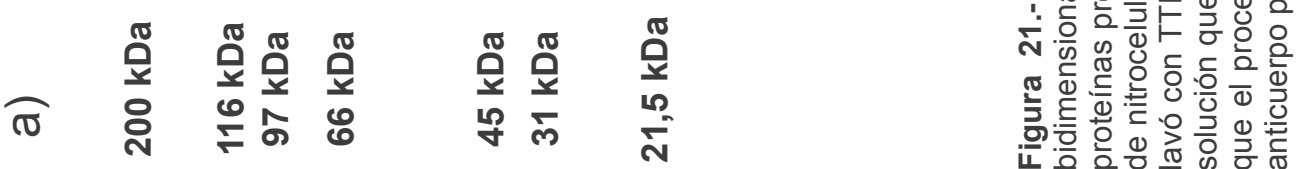


a)

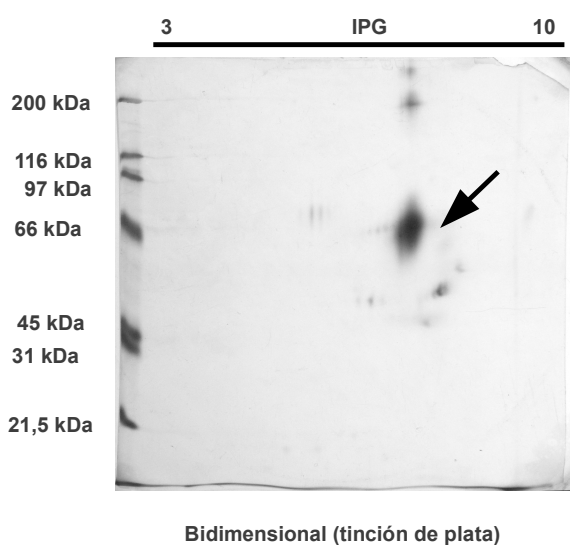

c)

Lista de Masas / Intensidad Relativa

\begin{tabular}{rrrr} 
Masa & \multicolumn{1}{c}{ I.R. } & 1069.6 & 794.48 \\
847.5 & 3274 & 1124.6 & 1556 \\
897.45 & 2808.3 & 1126.6 & 11142 \\
905.46 & 1698 & 1165.7 & 664.75 \\
947.47 & 997.28 & 1186.6 & 1157.5 \\
1009.5 & 3348.2 & 1277.7 & 1701.5 \\
1011.7 & 7581.2 & 1330.8 & 2778 \\
1023.5 & 700.51 & 1383.7 & 3235.4
\end{tabular}

\section{Resultados}

$\begin{array}{ll}\text { Mass } & \text { Score } \\ 60233 & 261 \\ 70166 & 238 \\ 70167 & 238 \\ 70239 & 238 \\ 70179 & 238 \\ 37541 & 157 \\ 66099 & 62 \\ 69118 & 60 \\ 69190 & 60 \\ 69103 & 60\end{array}$

b)

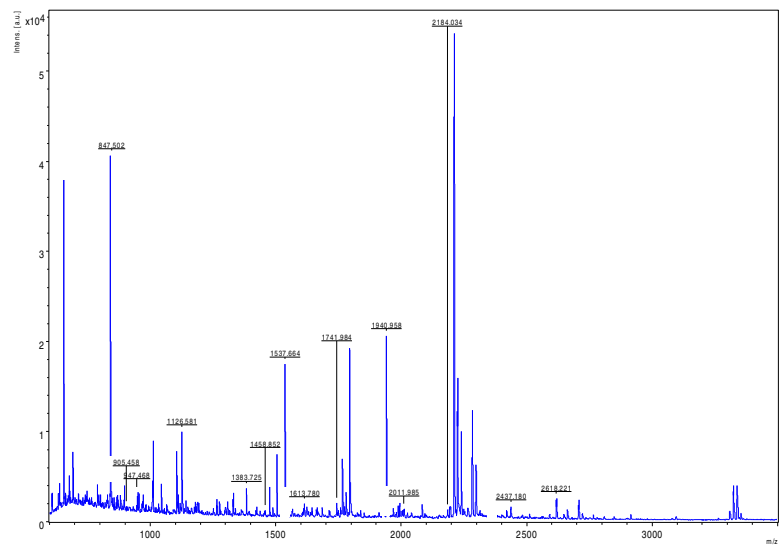

$\begin{aligned} & \text { Accession } \\ & \text { 1. } \text { gi| } 809077 \\ & \text { 2. } \text { gi|6978471 } \\ & \text { 3. } \text { gi|228784 } \\ & \text { 4. } \text { gi|67677932 } \\ & \text { 5. gi|149033755 } \\ & \text { 6. gi|149033756 } \\ & \text { 7. gi|74223003 } \\ & \text { 8. gi|163310738 } \\ & \text { 9. gi|26345198 } \\ & \text { 10. gi|26345002 }\end{aligned}$

$\begin{array}{rr}1458.9 & 1251 \\ 1475.8 & 3407.1 \\ 1488.7 & 1028.7 \\ 1504.7 & 6968.7 \\ 1537.7 & 16400 \\ 1613.8 & 1364.3 \\ 1622.8 & 961.96 \\ 1644.8 & 944.56\end{array}$

$\begin{array}{rr}1684.9 & 1032.8 \\ 1742 & 1534.5 \\ 1922.9 & 2412.2 \\ 1931 & 2099.6 \\ 1941 & 18446 \\ 1987 & 1205 \\ 2012 & 838.85 \\ 2101.2 & 721\end{array}$

$2196.1 \quad 692.84$

$2437.2 \quad 910.3$

$2618.2 \quad 1703.1$

$2662.2 \quad 685.76$
Description

alpha-fetoprotein [Rattus norvegicus]

alpha-fetoprotein precursor [Rattus norvegicus]

alpha fetoprotein

Alpha-fetoprotein [Rattus norvegicus]

alpha-fetoprotein, isoform CRA_a [Rattus norvegicus]

alpha-fetoprotein, isoform CRA_b [Rattus norvegicus]

unnamed protein product [Mus musculus]

alpha-fetoprotein precursor [Mus musculus]

unnamed protein product [Mus musculus]

unnamed protein product [Mus musculus]

Figura 22.- Análisis proteómico de la AFP obtenida tras la purificación. a) Los resultados aquí mostrados pertenecen la mancha más notable presente en el gel bidimensional (señalado con una flecha). La información relativa a el resto de las manchas, así como a los otros lotes de AFP, aparece en el anexo. Brevemente, para el análisis de la huella peptídica se recortó un fragmento de esta mancha, se digirió en tripsina y posteriormente los fragmentos obtenidos se analizaron mediante MALDI-TOF. Los resultados se contrastaron con la base de datos de NCBInr. b) Espectro de masas correspondiente a los fragmentos obtenidos tras la tripsinización. c) Resultados obtenidos del análisis de los datos del MALDI-TOF. El valor Score es $-10^{*} \log (P)$, siendo $P$ la probabilidad de que el resultado obtenido sea al azar. El resultado se considera significativo $(p<0.05)$ cuando el valor del Score es superior a 66. 


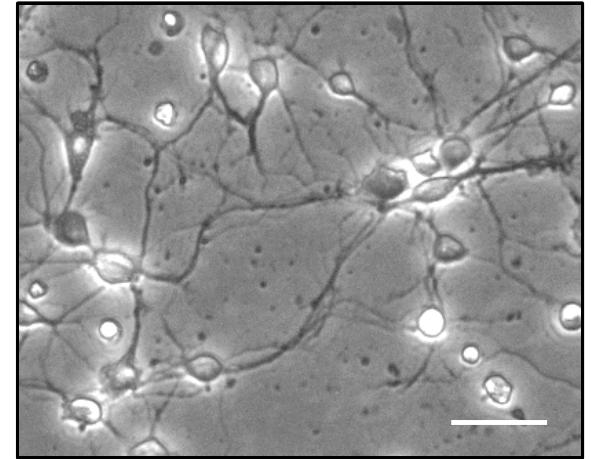

MD

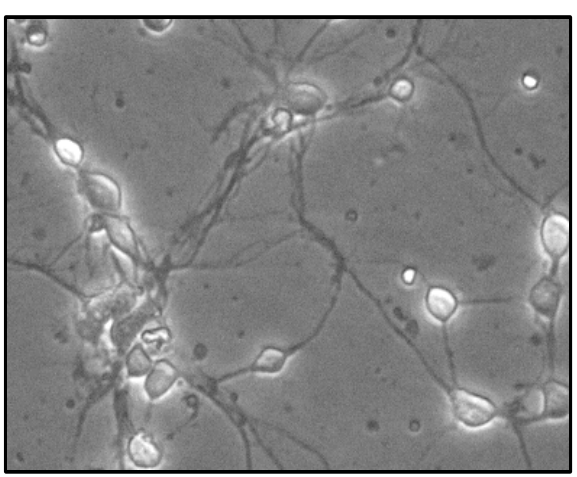

AFP $0,000625 \%$

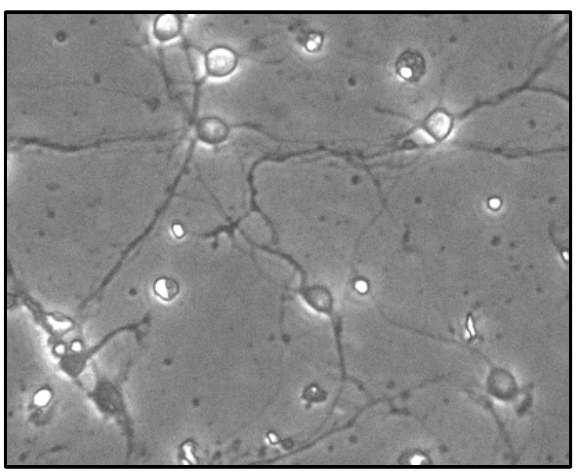

AFP $0,0025 \%$

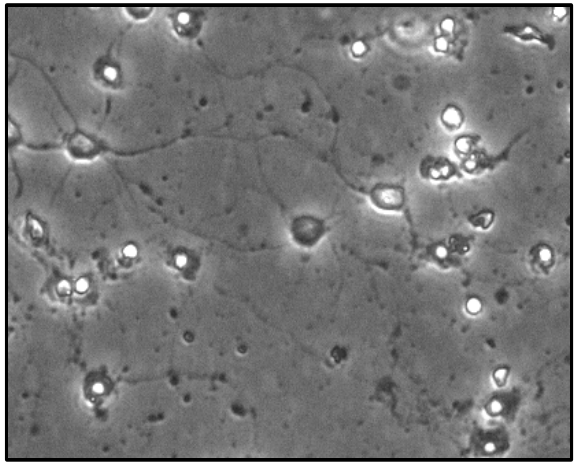

AFP $0,01 \%$

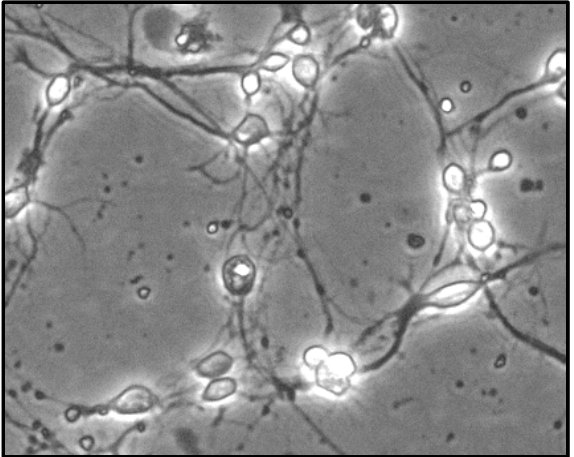

AFP $0,00005 \%$

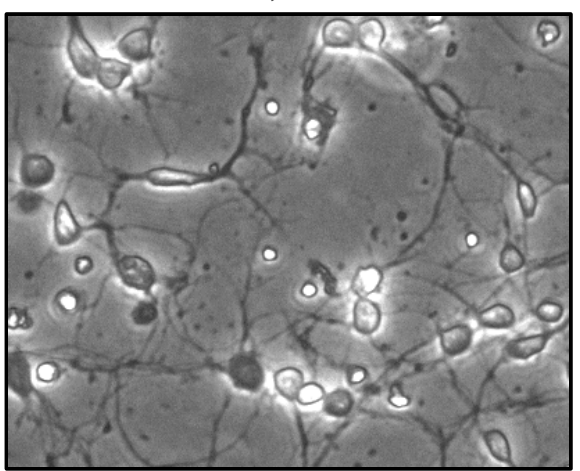

AFP $0,00125 \%$

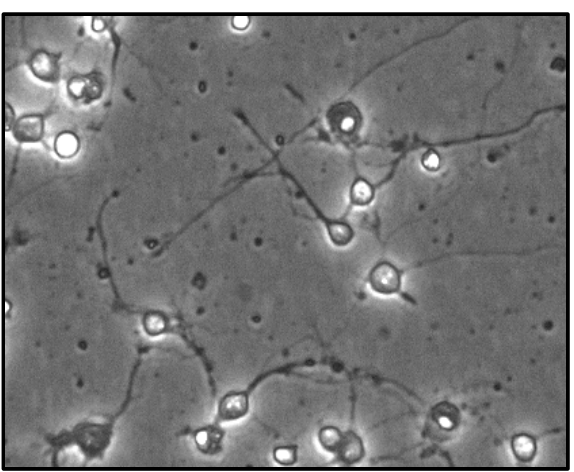

AFP $0,005 \%$

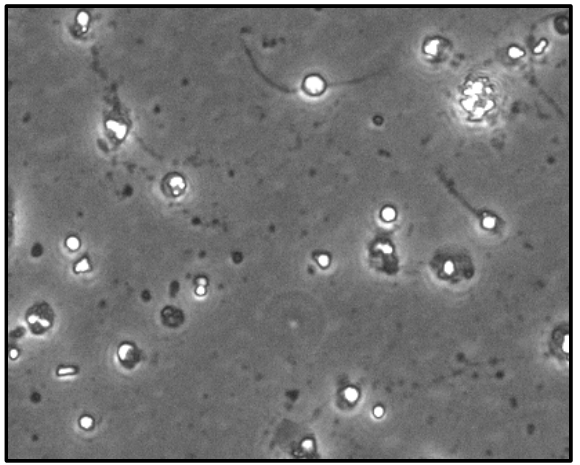

AFP $0,02 \%$

Figura 23.- Efecto de la AFP sobre la morfología las neuronas en cultivo primario. Fotografías de contraste de fases, obtenidas a 20 aumentos, de neuronas en cultivo primario sometidas a concentraciones crecientes de AFP. La barra de escala corresponde a $25 \mu \mathrm{m}$. 


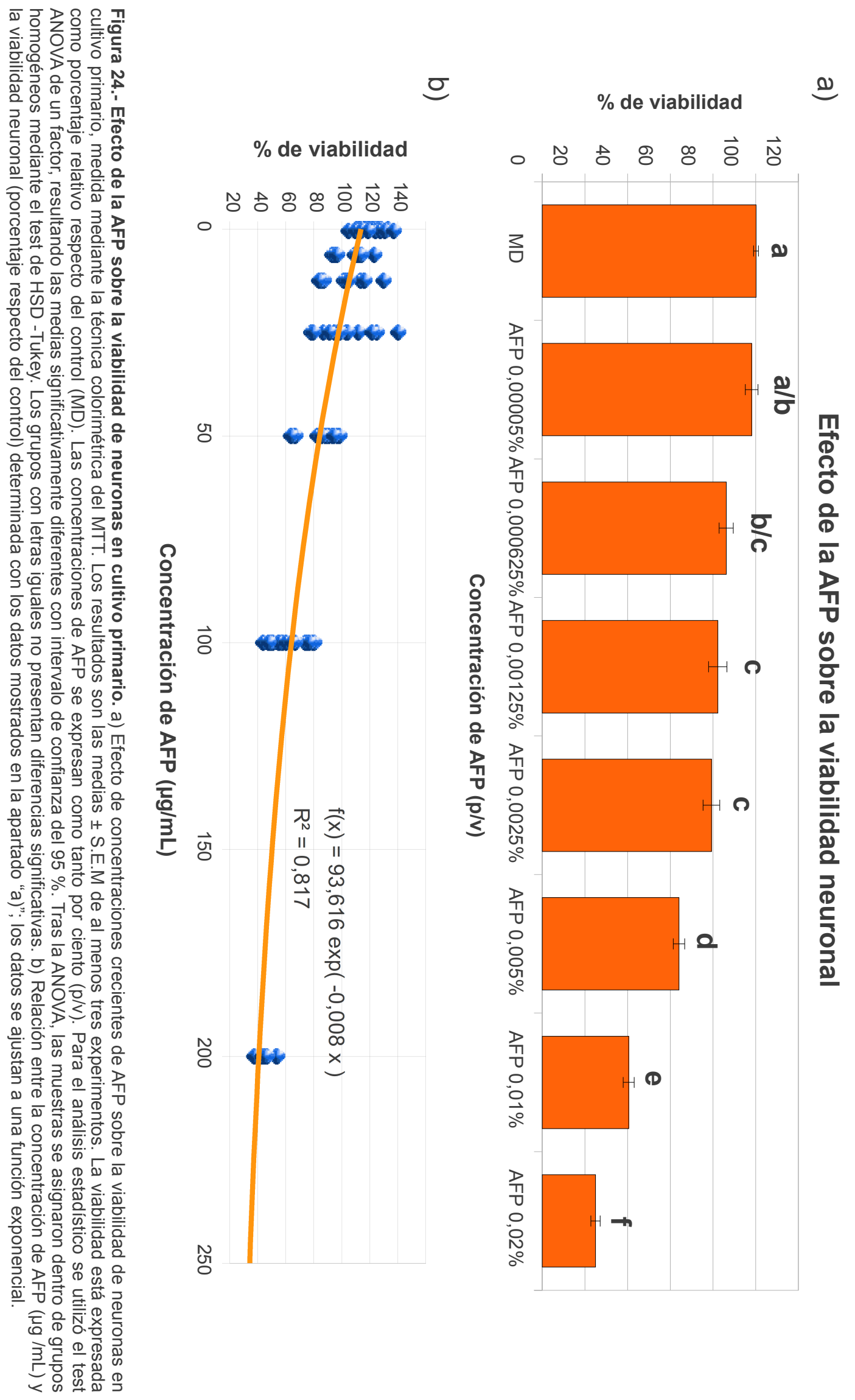


a)
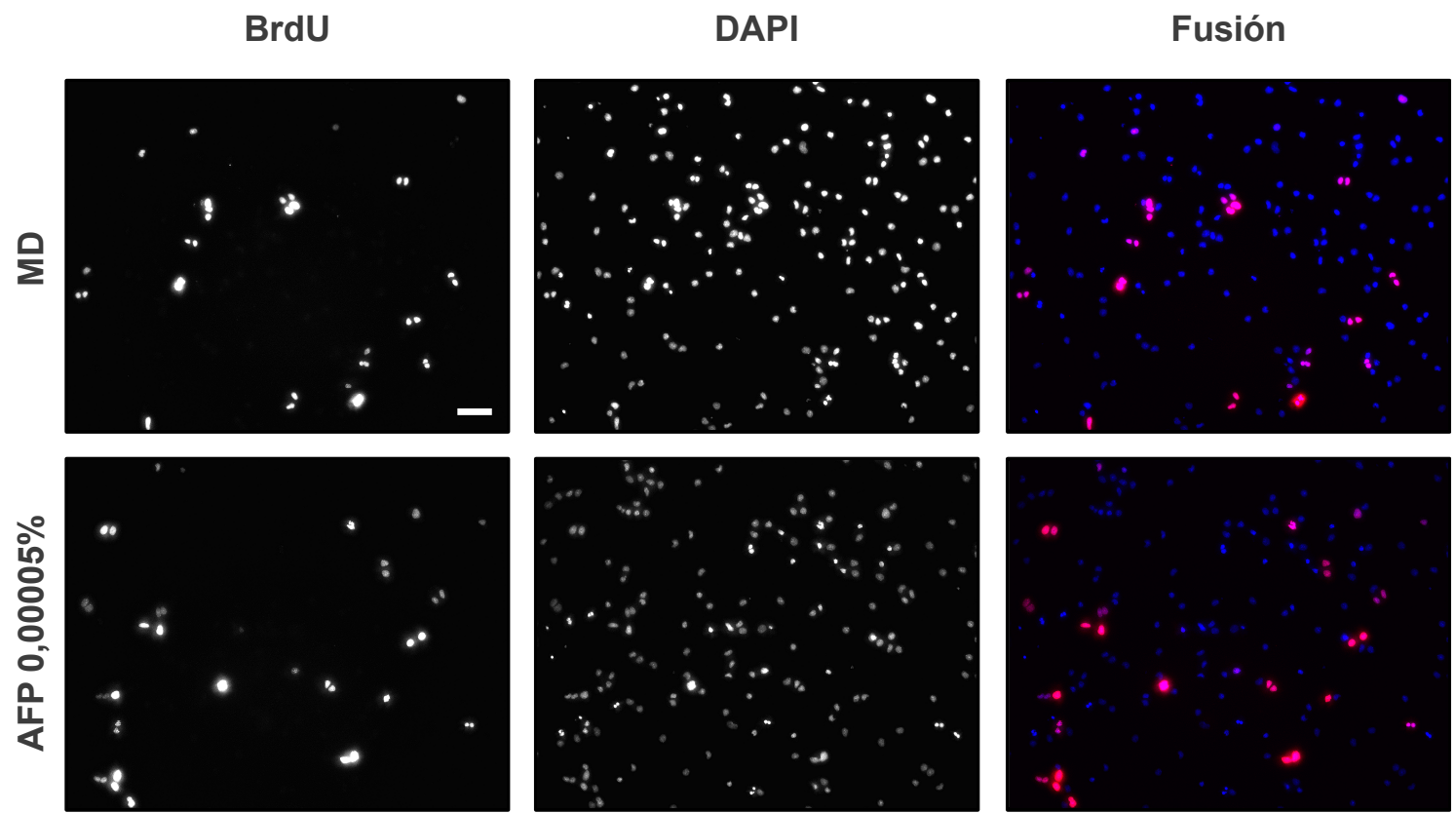

b)

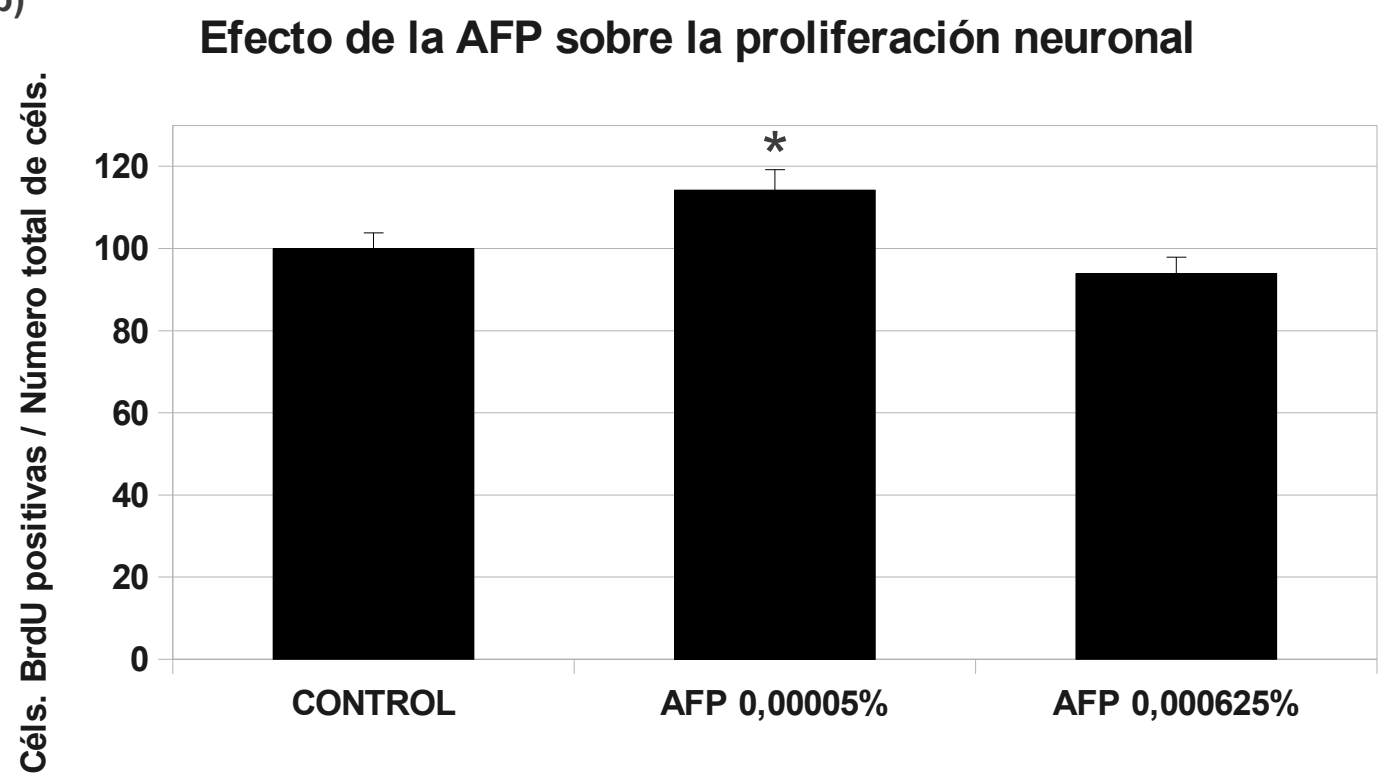

Figura 25.- Efecto de la AFP sobre la proliferación neuronal in vitro. Las neuronas se incubaron con BrdU $10 \mu \mathrm{M}$ durante 24 horas, en ausencia de concentraciones decrecientes de AFP. Transcurrido ese tiempo las células se fijaron con PFA 4\%. a) Posteriormente se realizó la inmunocitoquímica contra la BrdU, quedando marcadas aquellas células en fase $S$ del ciclo celular. La tinción nuclear se realizó mediante DAPI. La barra de escala corresponde a $50 \mu \mathrm{m}$. b) Los resultados mostrados son las medias \pm SEM de al menos 3 experimentos independientes y aparecen representados como la razón del número de células BrdU positivas dividido por el número total de células en cada campo. El análisis estadístico se realizó mediante el test $t$ de Student, considerándose las diferencias entre cada grupo y el control significativas, ${ }^{*} p<0,05,{ }^{* *} p<0,01$ y ${ }^{* * *} p<$ 0,001 . 
a)

$\square$ AFP $\square$ T-kininógeno $\square$ Alfa-1-antitripsina $\square$ Disulfuro isomerasa

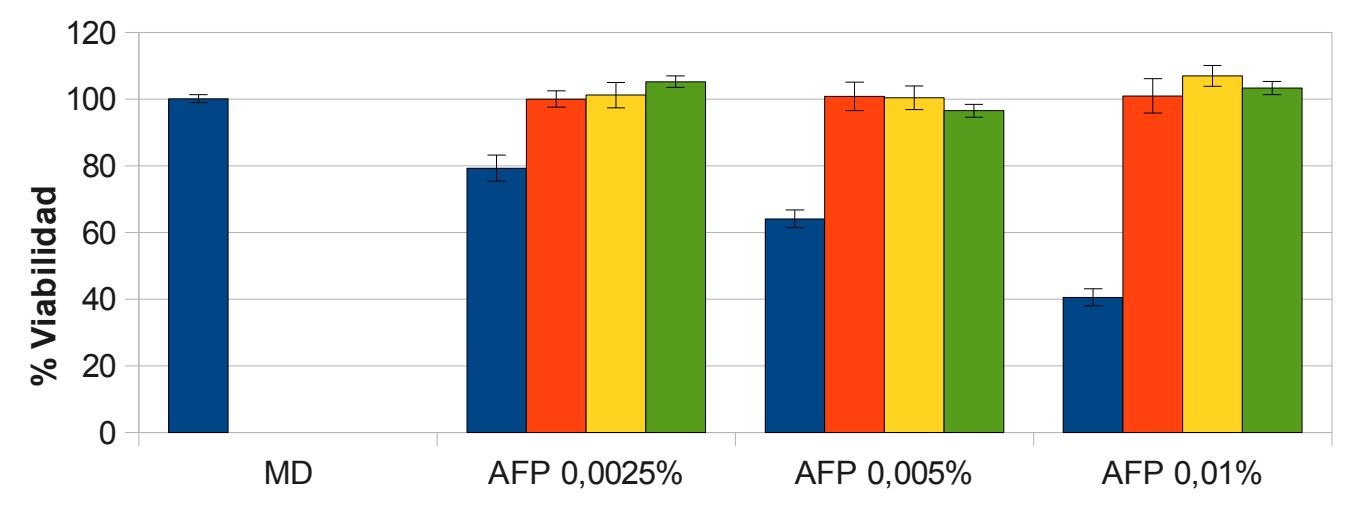

b)
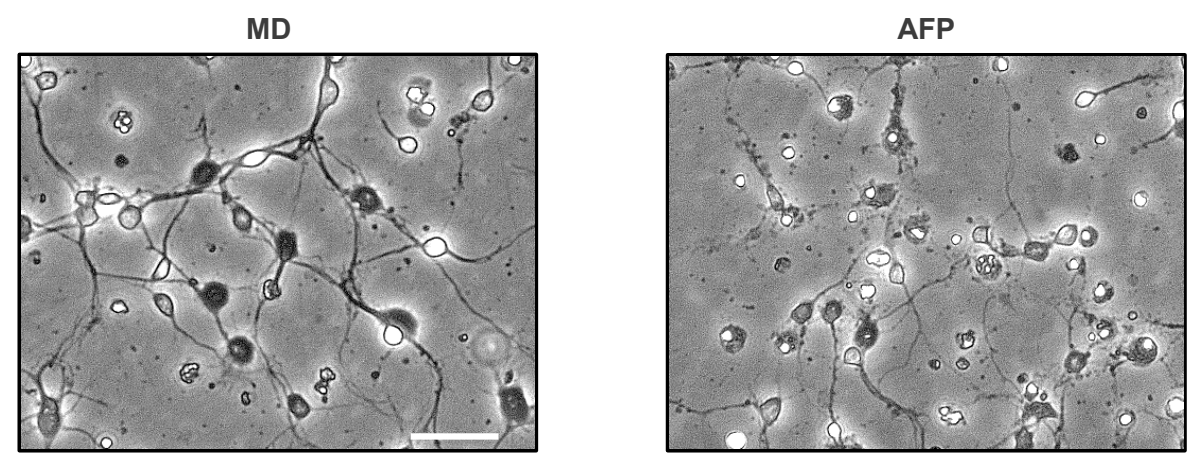

T-kininógeno

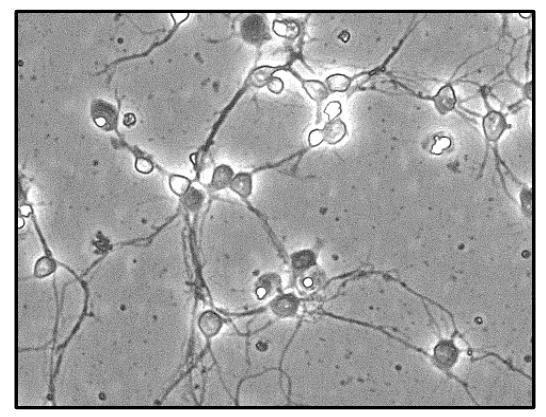

Alfa-1-antitripsina

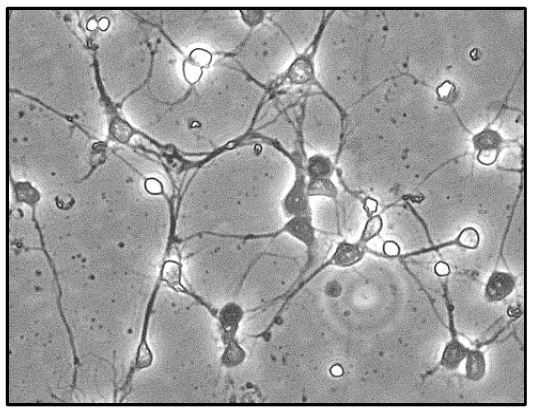

Disulfuro isomerasa

Figura 26.- Efecto de otras proteínas presentes como trazas en el purificado de AFP sobre la viabilidad neuronal in vitro. a) Cuantificación de la viabilidad. Las neuronas en cultivo primario se incubaron durante 72 horas con concentraciones equivalentes (en función de la presencia relativa en el purificado) de T-kinógeno, alfa-1-antitripsina y disulfido isomerasa. La viabilidad se determinó mediante el método colorimétrico del MTT. La viabilidad está expresada como porcentaje relativo respecto del control (medio definido) y son las medias \pm S.E.M de al menos tres experimentos. Las concentraciones de AFP en $\mathrm{g} / 100 \mathrm{~mL}$. b) Fotografías en contraste de fases de las neuronas en cultivo primario. La barra de calibrado corresponde a $25 \mu \mathrm{m}$.

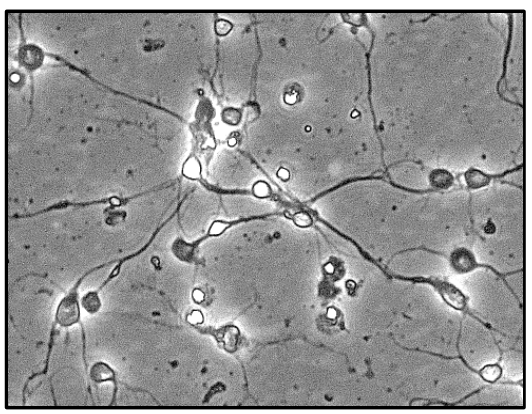


a)

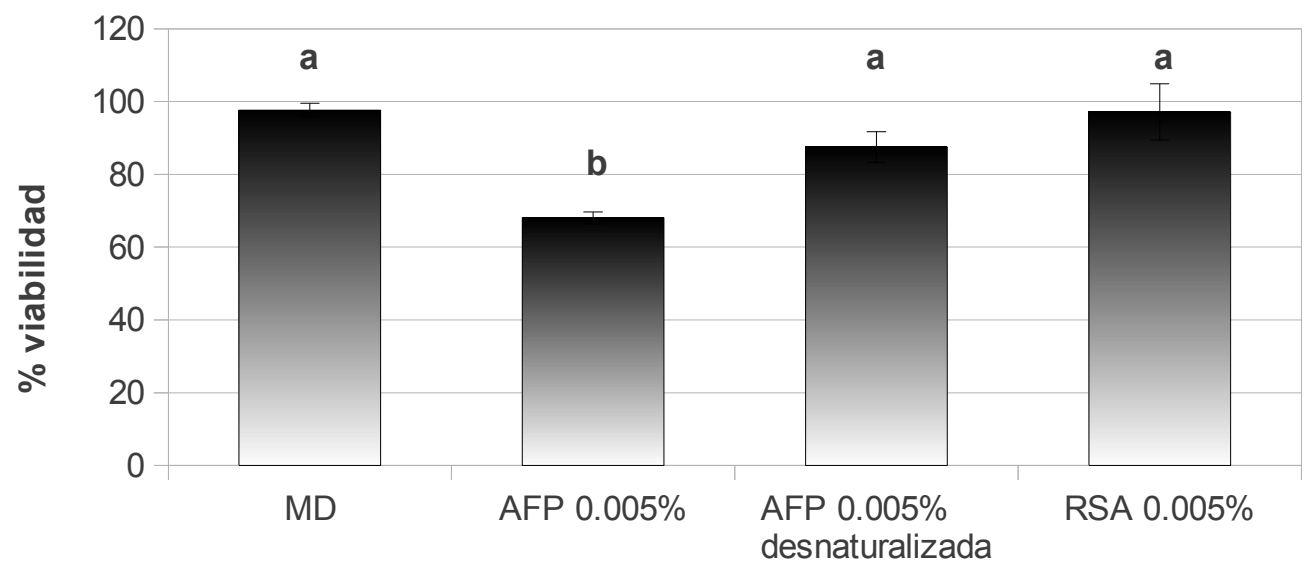

b)

Tratamiento

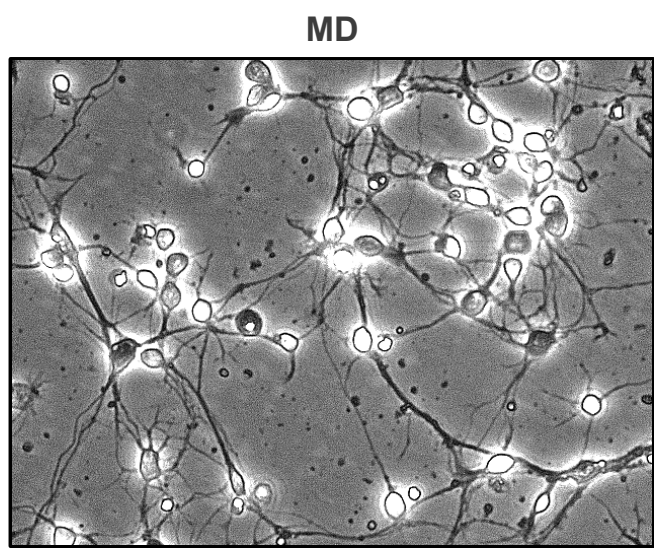

AFP $0,005 \%$ desnaturalizada

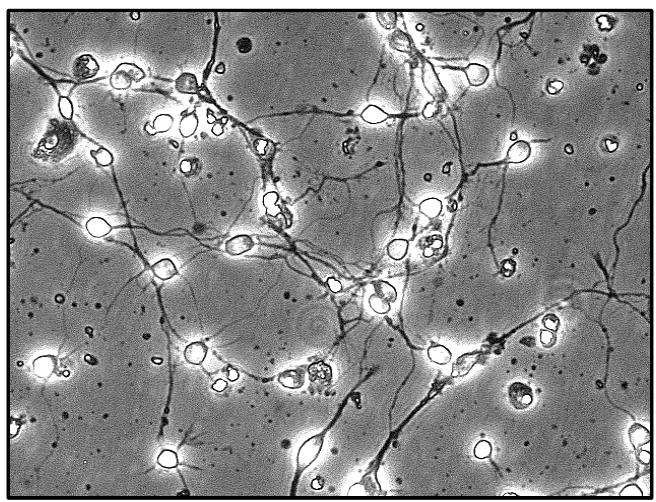

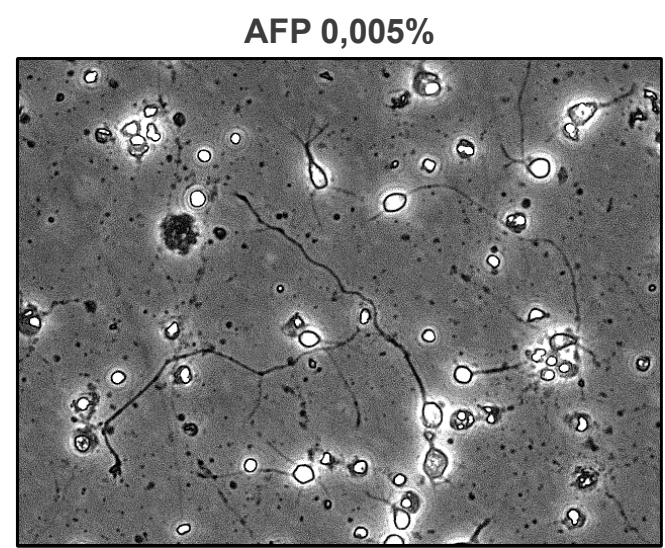

RSA $0,005 \%$

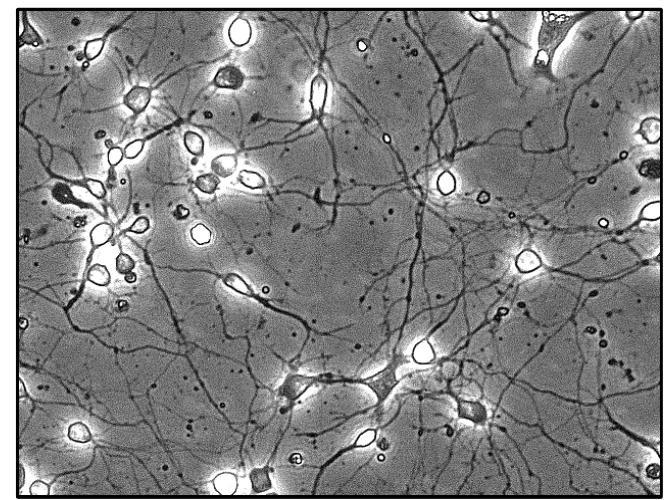

Figura 27.- Efecto de la AFP desnaturalizada y de la albúmina de rata sobre la supervivencia de neuronas en cultivo primario. a) Cuantificación de la viabilidad. Las neuronas en cultivo primario se incubaron durante $72 \mathrm{~h}$, con AFP, con AFP desnaturalizada y con albúmina de rata (RSA) obtenida a partir de células de hepatoma siguiendo el mismo proceso que la AFP. La viabilidad se determinó mediante el método colorimétrico del MTT. La viabilidad está expresada como porcentaje relativo respecto del control (medio definido) y son las medias \pm S.E.M. de al menos tres experimentos diferentes. Las concentraciones de AFP se expresan como tanto por ciento $(\mathrm{p} / \mathrm{v})$. Para el análisis estadístico se utilizó el test ANOVA de un factor, resultando las medias significativamente diferentes con intervalo de confianza del $95 \%$. Tras la ANOVA, las muestras se asignaron dentro de grupos homogéneos mediante el test de HSD -Tukey. Los grupos con letras iguales no presentan diferencias significativas. b) Fotografías en contraste de fases de las neuronas en cultivo primario. La barra de calibrado corresponde a $25 \mu \mathrm{m}$. 


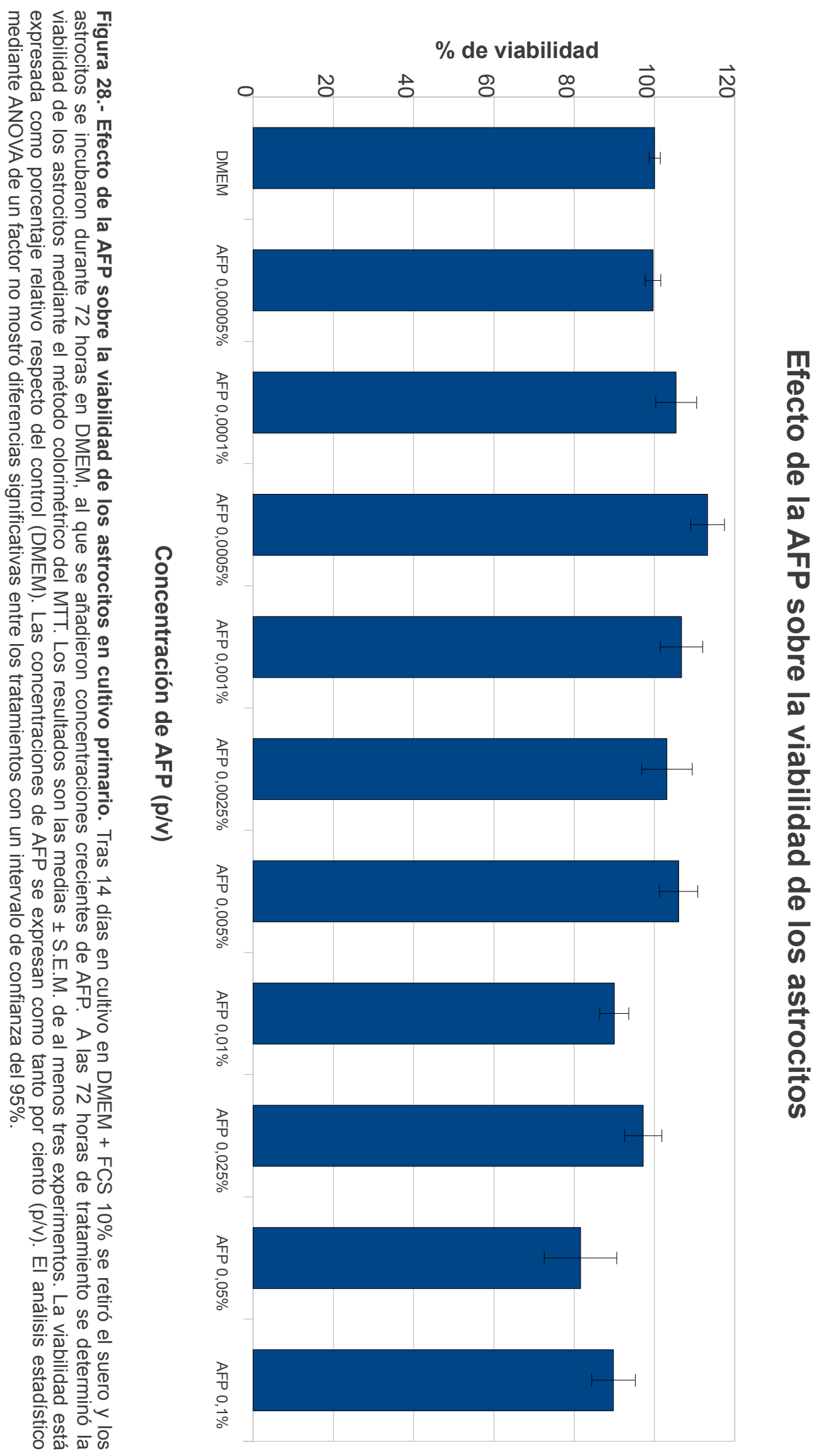



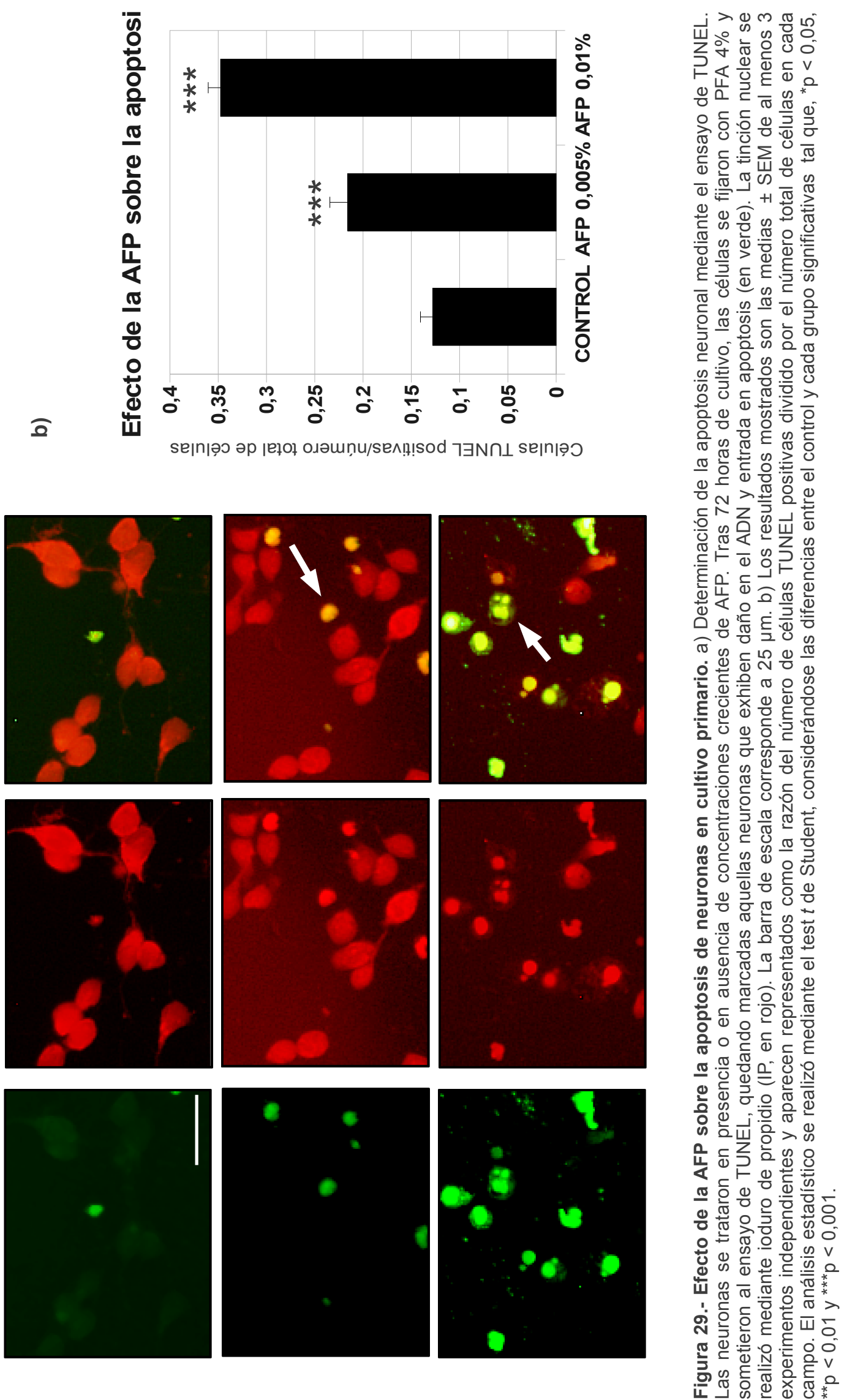
a)

BSA $2 \%$

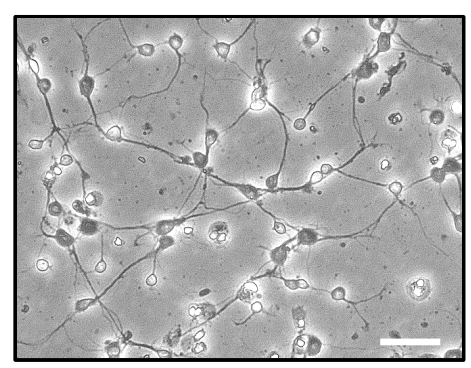

BSA + O + AFP $\quad 0,005 \%$

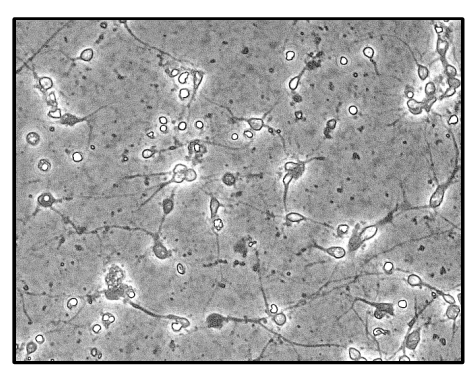

BSA $2 \%+$ O $50 \mu \mathrm{M}$

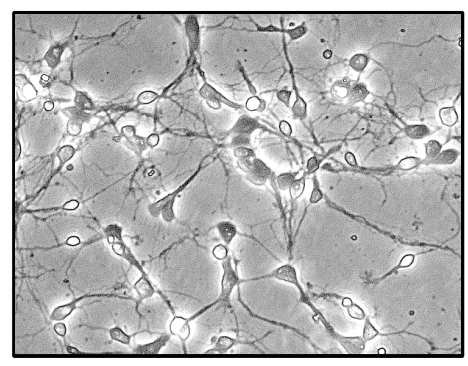

BSA + O + AFP $\quad 0,01 \%$

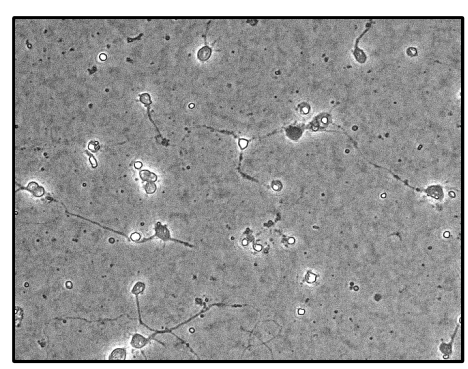

BSA $2 \%$ + O $50 \mu \mathrm{M}$ AFP + 0,0025\%

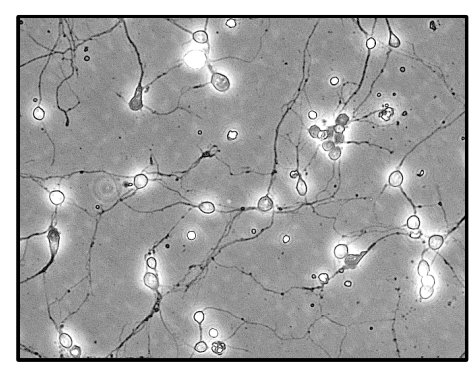

$B S A+0+$ AFP $0,02 \%$

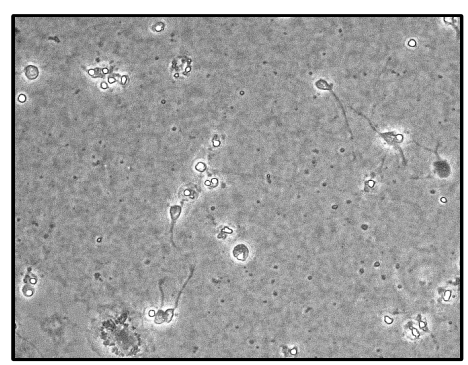

b)

\section{Efecto dosis respuesta de la AFP sobre la viabilidad en presencia del complejo BSA + O}

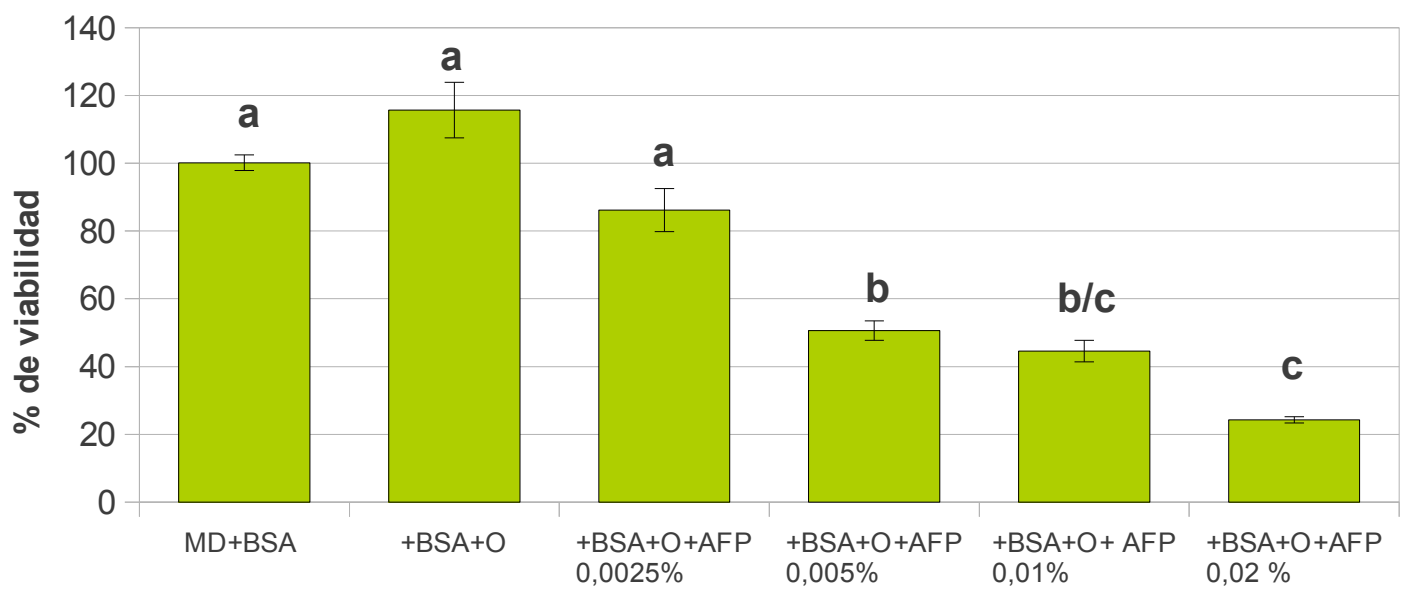

Tratamiento

Figura 30.- Efecto de la AFP sobre la viabilidad neuronal en presencia del complejo albúmina-ácido oleico. a) Las neuronas en cultivo primario se incubaron durante 72 horas, en presencia o ausencia de AFP a la que se añadió BSA al $2 \%$ o el complejo BSA+O (BSA $2 \%$ suplementada con ácido oleico al $50 \mu \mathrm{M}$ ). La barra de calibrado corresponde a $25 \mu \mathrm{m}$. b) Cuantificación de la viabilidad. La viabilidad se determinó mediante el método colorimétrico del MTT. La viabilidad está expresada como porcentaje relativo respecto del control (medio definido) y son las medias \pm S.E.M de al menos tres experimentos diferentes. Las concentraciones de AFP se expresan como tanto por ciento $(p / v)$. Para el análisis estadístico se utilizó el test ANOVA de un factor, resultando las medias significativamente diferentes con intervalo de confianza del $95 \%$. Tras la ANOVA, las muestras se asignaron dentro de grupos homogéneos mediante el test de HSD -Tukey. Los grupos con letras iguales no presentan diferencias significativas 
a)

MAP-2

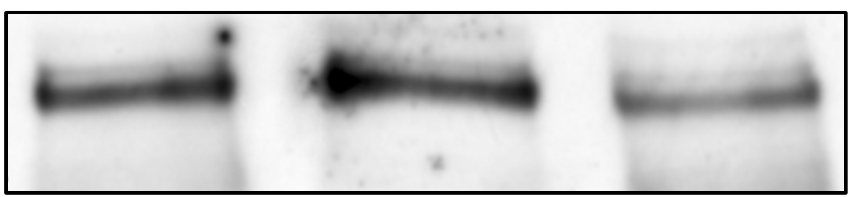

$250 \mathrm{kDa}$

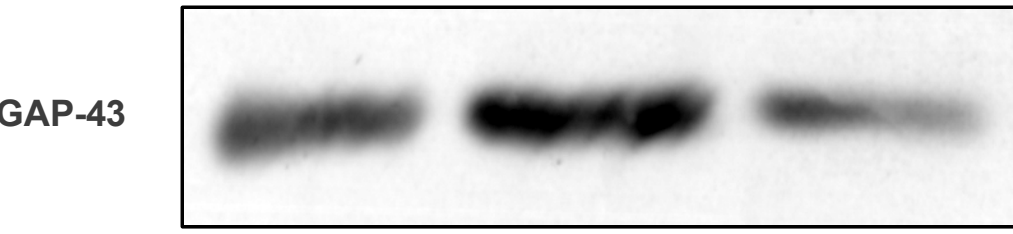

- $50 \mathrm{kDa}$

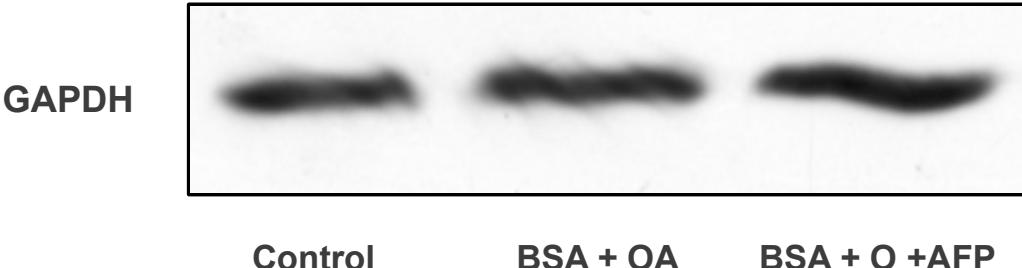

$37 \mathrm{kDa}$

b)

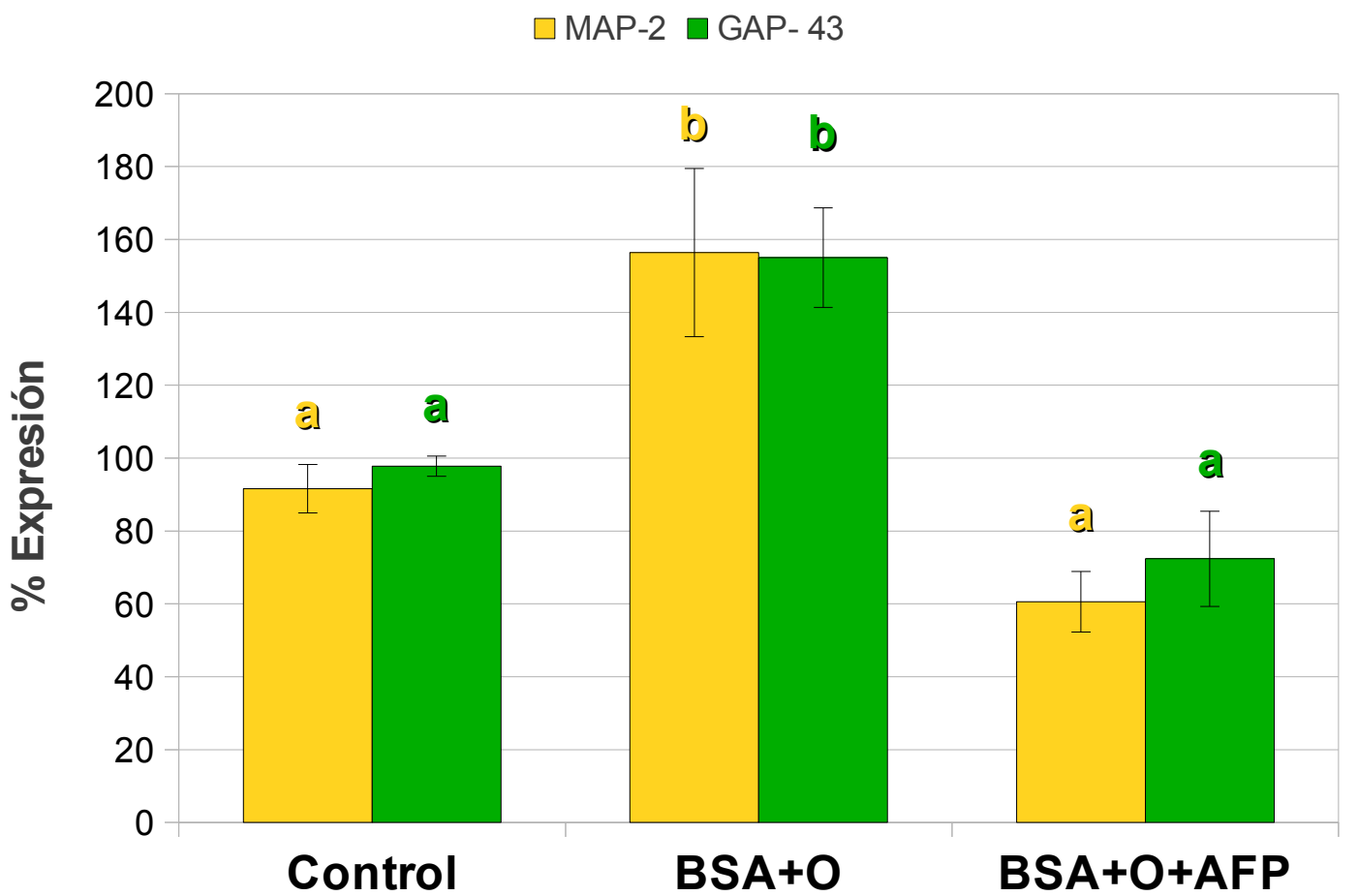

Tratamiento

Figura 31.- Efecto de la AFP sobre la expresión de MAP-2 y GAP-43 en neuronas. a) Las neuronas en cultivo primario se incubaron durante 72 horas en presencia de BSA $2 \%$, BSA $2 \%$ suplementada con ácido oleico (O) $50 \mu \mathrm{M}$, BSA con ácido oleico y AFP $0,0025 \%$. Posteriormente se extrajeron las proteínas y estás se resolvieron mediante western blot. b) Los resultados de al menos tres experimentos se promediaron y representaron gráficamente como las medias \pm S.E.M. Para el análisis estadístico se utilizó el test ANOVA de un factor, resultando las medias significativamente diferentes con intervalo de confianza del $95 \%$. Tras la ANOVA, las muestras se asignaron dentro de grupos homogéneos mediante el test de HSD -Tukey. Los grupos con letras iguales no presentan diferencias significativas. 


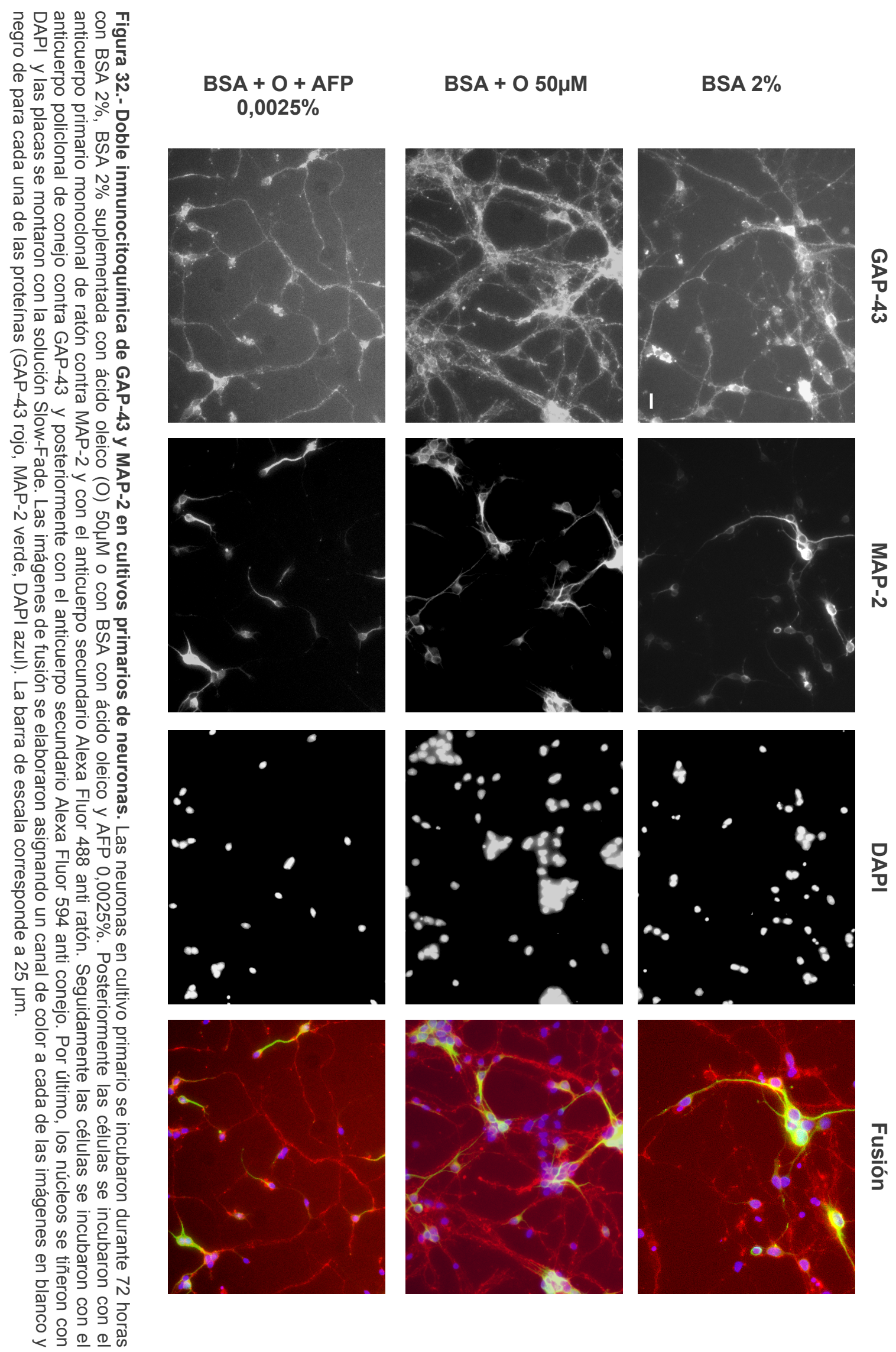


a)

b)

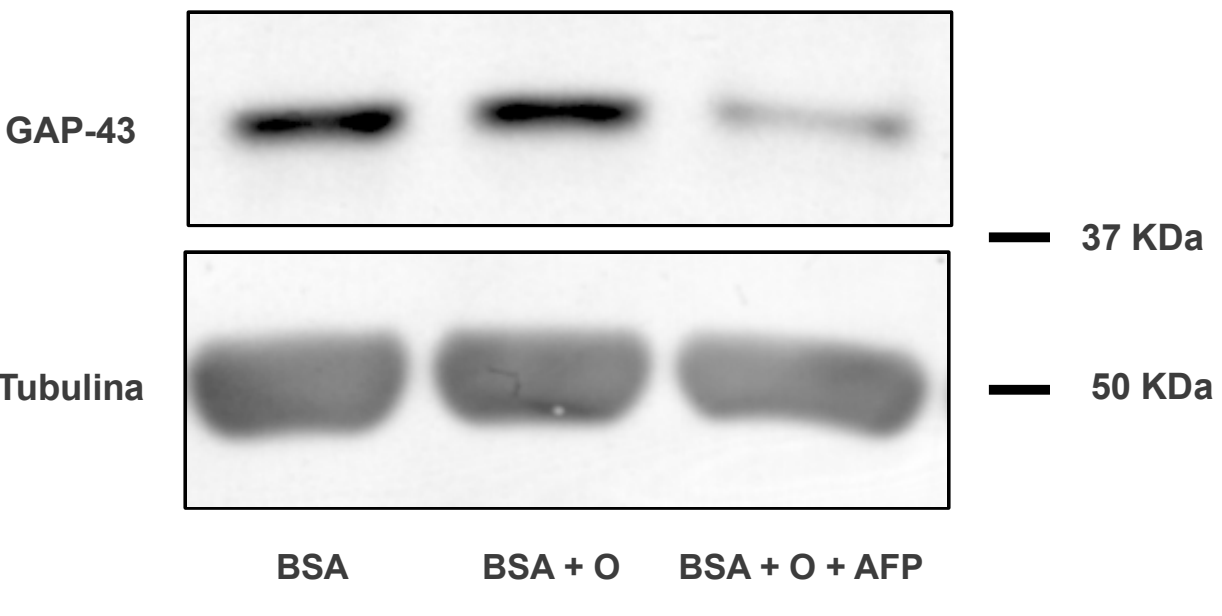

Efecto de la AFP en cultivos organotípicos

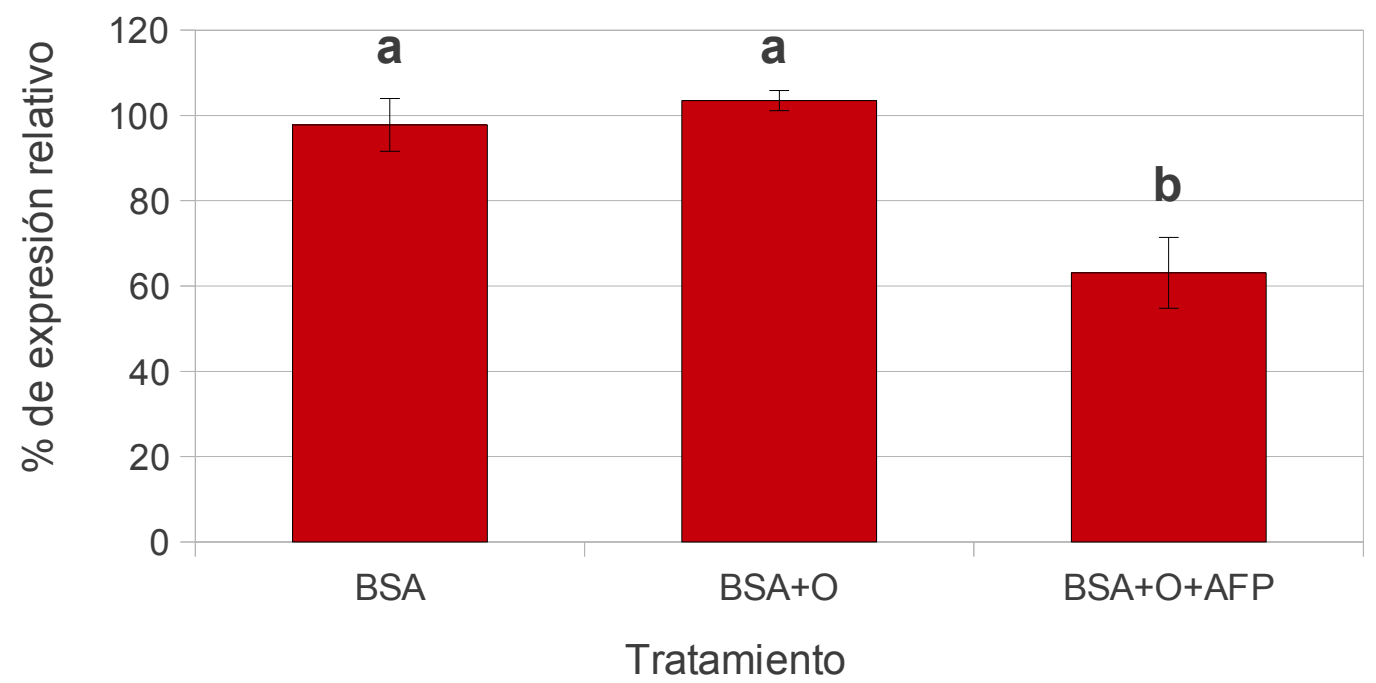

Figura 33.- Efecto de la AFP sobre los niveles de GAP-43 en cultivos organotípicos de cerebro de rata en E17,5. A partir de cerebros de embriones de 17,5 días de gestación, se obtuvieron secciones de $250 \mu \mathrm{m}$ que fueron cultivadas sobre en medio "Neurobasal" con BSA al $2 \%$, BSA con oleico al $50 \mu \mathrm{M}$ o BSA con oleico y AFP al $0,0025 \%$ durante 48 horas. Posteriormente se extrajeron las proteínas y éstas se resolvieron mediante Western blot. a) Western blot de GAP-43 y tubulina (utilizada como control de carga). b) Los resultados de al menos tres experimentos se representaron gráficamente como las medias \pm S.E.M. Para el análisis estadístico se utilizó el test ANOVA de un factor, resultando las medias significativamente diferentes con intervalo de confianza del $95 \%$. Tras la ANOVA, las muestras se asignaron dentro de grupos homogéneos mediante el test de HSD -Tukey. Los grupos con letras iguales no presentan diferencias significativas. 


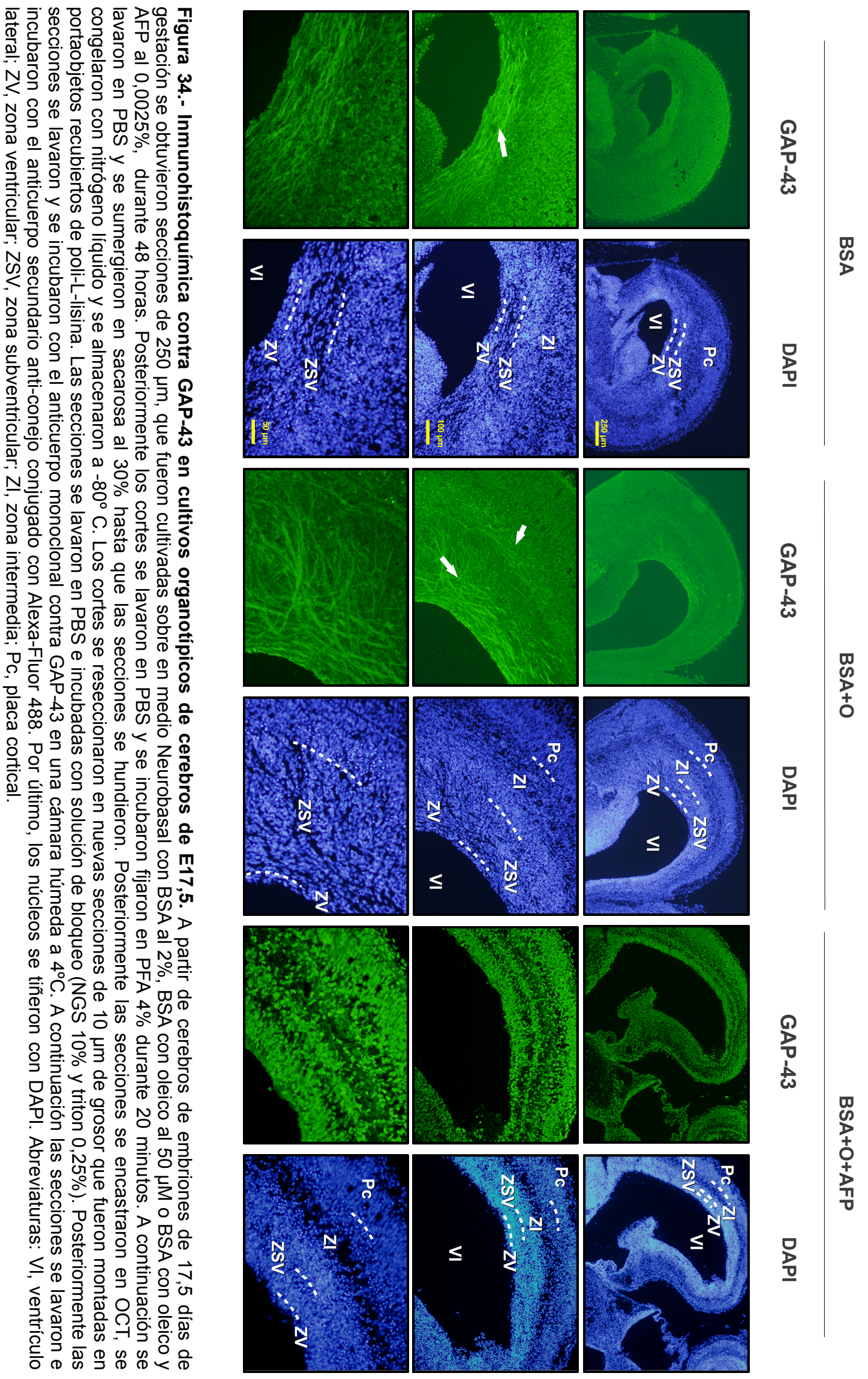




\section{DISCUSIÓN}


El desarrollo del cerebro de los mamíferos comprende un conjunto de etapas perfectamente coordinadas, las cuales darán lugar a la formación de las estructuras que conformarán el sistema nervioso y a su diferenciación. En el caso de los roedores y los primates, durante la etapa prenatal se producen el conjunto de fases que llevan a la formación del sistema nervioso con una histoarquitectura muy similar a la que presentará en la vida adulta.

Trabajos previos de nuestro grupo han demostrado que la síntesis del ácido oleico inducida por la albúmina en los astrocitos produce la diferenciación neuronal coincidiendo con el desarrollo postnatal del cerebro (Medina y Tabernero 2002). De hecho, hemos descrito cómo la SCD-1, la enzima limitante en la síntesis del ácido oleico, se localiza en la zona subventricular del cerebro, y cómo el ácido oleico actúa sobre la diferenciación de las neuronas del núcleo estriado durante ese periodo (Polo-Hernández y col. 2010). Por tanto, en nuestro grupo se ha estudiado ampliamente la implicación del ácido oleico como factor neurotrófico y de la albúmina como proteína clave de este proceso, durante el desarrollo postnatal. Sin embargo desconocíamos si estos mismos procesos podrían estar llevándose a cabo durante la etapa embrionaria del desarrollo del cerebro.

En ese sentido, se conoce desde hace tiempo que durante el periodo embrionario los niveles de albúmina en plasma y líquido cefalorraquídeo (LCR) son más bajos a los presentes en la etapa postnatal. Sin embargo, se detectan niveles más elevados de alfa-fetoproteína (AFP) (Dziegielewska, Evans, Lai, y col. 1981). Tal y como se describe en la introducción, la AFP es una proteína muy similar a la albúmina, con la que comparte una importante característica, es decir el transporte de ácidos grasos. Al observar la existencia de una aparente intercambio entre la AFP y la albúmina entre las etapas prenatal y postnatal de desarrollo del cerebro, nos planteamos la posibilidad de que la AFP jugara un papel similar al de la albúmina, durante la etapa embrionaria. Por tanto, nuestras primeras hipótesis se encaminaron en ese sentido.

\subsection{Determinación de la edad gestacional}

Al inicio de abordar estos estudios se nos planteó la necesidad del establecimiento de un protocolo preciso y fiable de determinación de la edad gestacional 


\section{Alejandro García García}

de los embriones en estudio. Pese al preciso control de los días de cruce por parte del personal del animalario, la experiencia nos ha demostrado como, algunas veces, los embriones presentaban un tamaño diferente al esperado para su edad gestacional. De tal manera, los datos presentes en la figura 1 sirvieron como referencia a lo largo de los experimentos realizados en la presente tesis. Esta referencia nos permitió decidir la inclusión en los consiguientes estudios de cada uno de los embriones obtenidos. Datos similares han sido obtenidos por otros autores en otras razas de rata (Johansson y col. 2006). A partir de los datos del peso fetal y peso del cerebro puede obtenerse el índice de encefalización (relación entre el peso del cerebro y el peso total del cuerpo). Este índice ha sido ampliamente utilizado por numerosos autores para el estudio comparativo del desarrollo del cerebro a lo largo de la evolución de los vertebrados mamíferos (Deacon 1990, 1997). En el esquema 17 puede observarse el índice de encefalización correspondiente al desarrollo embrionario de la rata. Así mismo se observa como evoluciona, a lo largo del desarrollo, el peso del feto respecto al peso del cerebro, y como esta evolución puede compararse con la de otros mamíferos, como los seres humanos, los cuales presentan un mayor grado de encefalización. De tal manera, comprobamos cómo el índice de encefalización determinado mediante nuestros resultados $(\approx 0,62)$, coincide con el índice determinado previamente para el conjunto del orden de los roedores $(\approx 0,57$, ver esquema 17$)$.

\subsection{La alfa-fetoproteína en el cerebro embrionario}

Una vez desarrollada la herramienta para la determinación con precisión de la edad gestacional, procedimos a estudiar de las proteínas plasmáticas AFP y albúmina en el cerebro durante la etapa embrionaria.

Tal y como se ha explicado en la introducción, la presencia de AFP en el cerebro y LCR de mamíferos durante el desarrollo aparece ampliamente descrito en la bibliografía (Attardi y Ruoslahti 1976; Møllgård y col. 1979; Toran-Allerand 1980; Trojan y Uriel 1980; Dziegielewska, Evans, Lai, y col. 1981; Uriel y col. 1981; Piñeiro y col. 1982; Kovářu y col. 1984). Sin embargo, se desconocían los niveles de esta proteína en el cerebro durante las etapas intermedias (E15-E18) y final (E20-P0) de desarrollo embrionario. 
a)

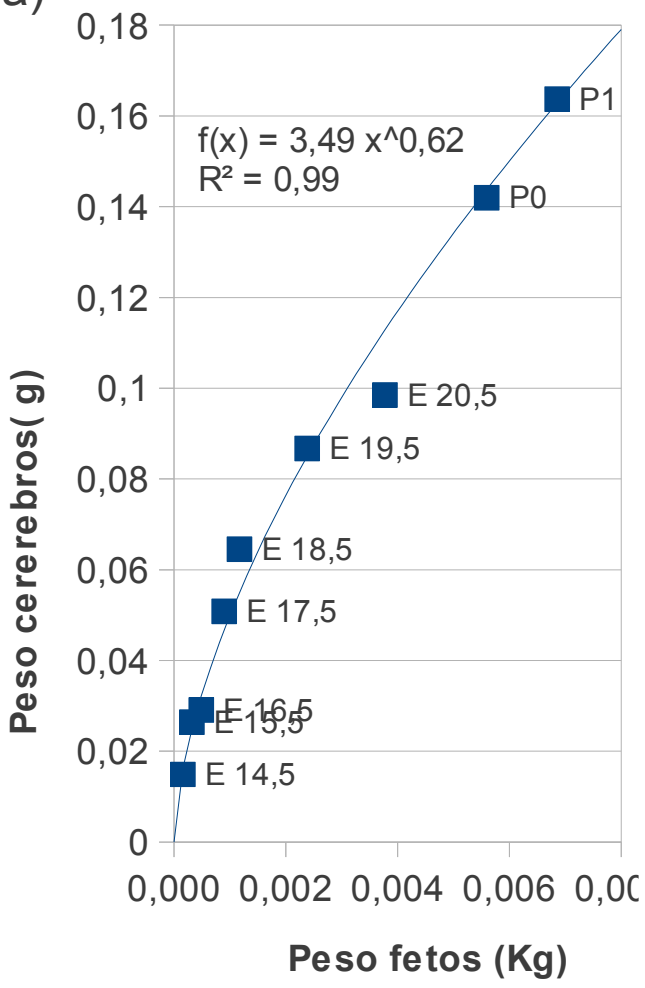

b)

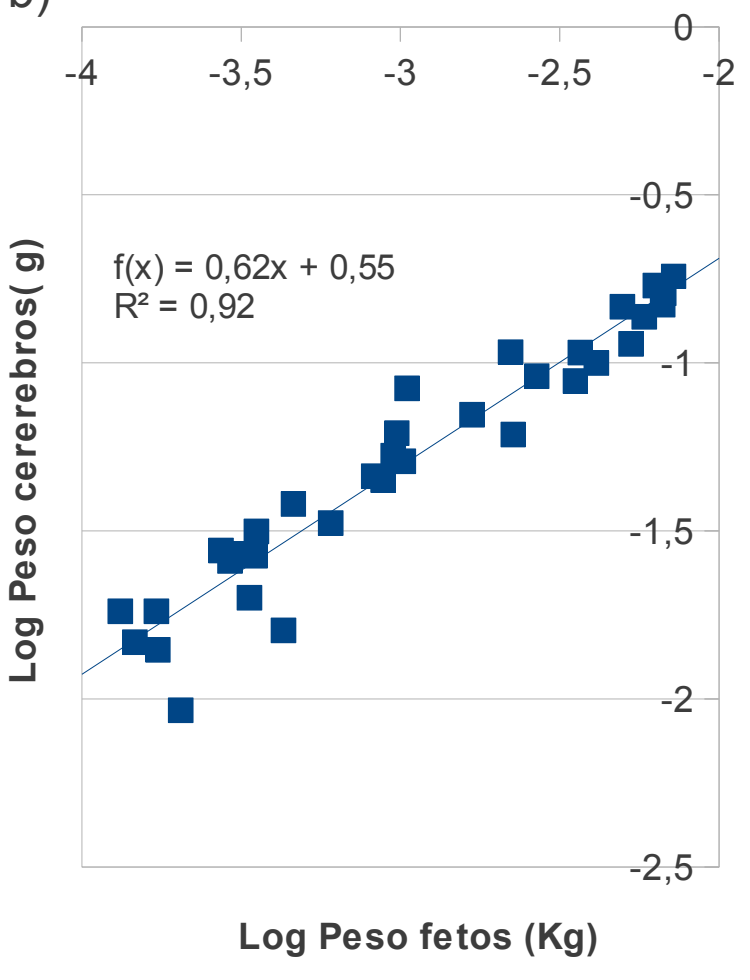

Momento aproximado del nacimiento

c)

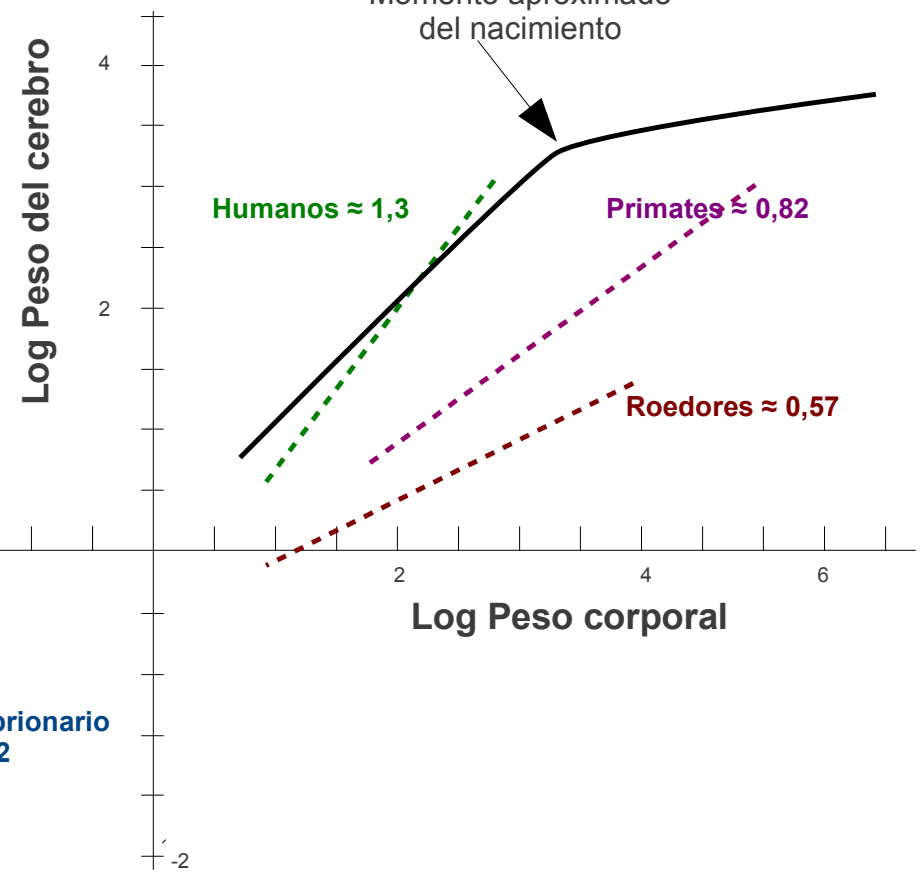

Esquema 17.- Relación entre el peso fetal y el peso del cerebro a lo largo del desarrollo. a) Los valores medios correspondientes al peso fetal ( $\mathrm{Kg}$, peso húmedo) y el peso del cerebro (g, peso húmedo) para cada día de gestación se representaron gráficamente y se ajustaron a una curva exponencial. b) Recta de regresión. del Log10 de los valores correspondientes al peso del feto y del cerebro de todos los embriones analizados. c) En negro se representa el esquema correspondiente al crecimiento del cerebro respecto del peso corporal para los mamíferos. En verde se representa la recta de crecimiento para los seres humanos, en morado para los primates, en rojo para los roedores (modificado de Deacon (Deacon 1990, 1997)). En azul se representa la recta obtenida de nuestros estudios para la rata durante el desarrollo embrionario. 


\section{Alejandro García García}

De tal manera, en el presente estudio, hemos confirmado que la AFP se encuentra presente en el cerebro durante el desarrollo embrionario (fig. 4). Esta proteína presenta altos niveles en el cerebro durante la mayor parte de la gestación, los cuales disminuyen días antes del parto. En este sentido, encontramos dos picos en los niveles de AFP, uno en torno al día E15,5, el cuál no aparece descrito en la bibliografía, y un segundo pico en torno al día E19,5, similar al descrito anteriormente en la bibliografía en el LCR (Dziegielewska, Evans, Lai, y col. 1981). En su estudio de las proteínas del LCR en la rata, Dziegielewska y colaboradores no muestran las mediciones de AFP correspondientes al día E16, el cuál en nuestro estudio corresponde con el día E15,5 (Dziegielewska, Evans, Lai, y col. 1981). Por otro lado, el acceso de las proteínas del LCR al parénquima cerebral se encuentra regulado por la presencia de la barrera LCR-cerebro (Johansson y col. 2008). De existir entonces una diferencia en los niveles de AFP entre el LCR y el cerebro, esto implicaría la existencia de un transporte específico de esta proteína al interior del parénquima, similar al descrito anteriormente para la albúmina (Cavanagh y Warren 1985). Cabe destacar que el "valle" definido por los picos de AFP (entre los días E15,5 y E19,5) coincide con el aumento drástico del volumen de distribución del LCR (en torno al día E16) al abrirse la comunicación entre el espacio ventricular y el espacio subaracnoideo. Ello produce la disminución de las concentraciones relativas de determinados marcadores respecto a las concentraciones presentes en el plasma, en torno a ese día (Dziegielewska, Evans, Lai, y col. 1981; Johansson y col. 2008). En ese caso, la presencia de AFP en el cerebro, estaría regulada por la concentración relativa de esta proteína en el LCR respecto a su concentración en el plasma.

En cuanto a la albúmina, podemos observar en la figura 3 como, esta proteína, al igual que la AFP, se encuentra presente en el cerebro durante el desarrollo. Sin embargo, los niveles de albúmina permanecen bajos durante la etapa intermedia de desarrollo embrionario del cerebro $(\mathrm{E} 14,5$ - E18,5) aumentando drásticamente el día E18,5 y manteniéndose hasta P1; tras este aumento, los niveles de albúmina en el cerebro disminuyen durante la primera semana de vida postnatal hasta prácticamente desaparecer en el cerebro adulto (Velasco y col. 2003). Estos datos se encuentran en consonancia con los resultados mostrados anteriormente por 
otros autores para el LCR (Dziegielewska, Evans, Lai, y col. 1981). En ese sentido, se ha descrito en la rata la presencia de un mecanismo específico de transporte de albúmina desde la sangre al LCR, el cuál parece estar activo ya en E15 (Johansson y col. 2006), así como la presencia de un mecanismo específico de transporte de albúmina del LCR al parénquima cerebral, el cual parece surgir en torno a E16 (Cavanagh y Warren 1985). Por tanto la presencia de la albúmina en el parénquima cerebral es debida a su internalización desde el LCR, encontrándose este proceso regulado por los cambios en la concentración de esta proteína en el LCR. La entrada de albúmina a través del plexo coroideo en el LCR es un proceso específico y regulado (Johansson y col. 2008; Liddelow y col. 2010).

El análisis inmunohistoquímico confirmó la presencia de estas proteínas plasmáticas en el cerebro embrionario y las diferencias en sus niveles, observadas mediante transferencia tipo Western. Así, se confirma que ambas proteínas presentan unos niveles similares el día E19,5, mientras que en el día E15,5 sólo se detecta presente la AFP. En cuanto a su localización, en el día E19,5 la AFP se encuentra principalmente en la zona ventricular, las áreas de materia blanca que limitan con la subplaca, la zona marginal y la placa cortical en forma de haces radiales que discurren entre los cuerpos celulares, con un patrón similar a lo largo del eje rostrocaudal. Así mismo la AFP marca fuertemente el plexo coroideo y los vasos sanguíneos del cerebro como reflejo del origen plasmático de esta proteína (Johansson y col. 2006). De igual manera, la albúmina en ese día presenta un patrón de distribución muy similar pero de intensidad más baja. Por otro lado, el día E15,5 encontramos un fuerte marcaje de la AFP en las áreas mas caudales, concretamente en las regiones que conformarán la amígdala, el tálamo y el hipotálamo. La presencia en el cerebro de la AFP en ese día es inversa a la densidad ceIular.

La presencia de estas proteínas plasmáticas en la ZV y la ZM el día E19,5 estaría relacionado con el transporte de estas proteínas desde el LCR hacia el parénquima cerebral a través de la barrera LCR-cerebro y la barrera aracnoidea ((Johansson y col. 2008) ver sección 1.3). En cuanto a la presencia de AFP y en menor medida de la albúmina en la subplaca, la presencia de proteínas plasmáticas en esta área ha sido descrita previamente por otros autores (Møllgård y Ja- 


\section{Alejandro García García}

cobsen 1984; Reynolds y Møllgård 1985; Wang y col. 2010). Nuestros resultados indican que desde la subplaca surge un marcaje radial hacia la placa cortical. Se ha descrito como las neuronas de la subplaca proyectan radialmente hacia la placa cortical (Kanold y Luhmann 2010). De hecho, en ratones transgénicos para GFP bajo un promotor que marca las proyecciones axonales de la subplaca se puede observar un patrón muy similar al observado para la AFP durante el día E19,5 (Jacobs y col. 2007).

Numerosos autores han destacado la importancia de la presencia de estas proteínas plasmáticas en el cerebro durante el desarrollo, al poseer la capacidad de transportar ligandos y más concretamente, de unir ácidos grasos (Dziegielewska y col. 2000; Johansson y col. 2008; Medina y Tabernero 2010). En nuestro grupo se ha demostrado como la albúmina induce en los astrocitos la síntesis y liberación del ácido oleico, el cual induce en neuronas su diferenciación, durante el desarrollo postnatal del cerebro (Medina y Tabernero 2010). Decidimos por tanto analizar la posible relación existente entre estas proteínas plasmáticas y el ácido oleico durante el desarrollo embrionario. El análisis de los ácidos grasos libres en el cerebro embrionario evidenció la presencia de un primer pico entre los días E15,5 y E18,5 del desarrollo embrionario y un segundo pico en el día 1 de vida postnatal, ya descrito anteriormente por nuestro grupo (Polo-Hernández y col. 2010). La razón entre el ácido oleico y el ácido palmítico refleja la actividad de la SCD-1, al tratarse esta proteína de la enzima limitante en el proceso de conversión del ácido palmítico en ácido oleico (para una revisión ver Paton y Ntambi 2009). De tal manera, puede observarse que los aumentos de la relación ácido oleico- ácido palmítico encontrados en la etapa postnatal y prenatal presentan niveles muy similares. Ello sugeriría que el ácido oleico también puede jugar un papel en el desarrollo del cerebro en la etapa embrionaria. 
Por otro lado, el aumento de los niveles de ácido oleico parece estar relacionado con los niveles de AFP presentes en el cerebro. De esta manera, se observa que los picos en los niveles de ácido oleico vienen precedidos de los picos en los niveles de AFP. Este perfil sugiere que la AFP podría estar regulando los niveles de ácido oleico, probablemente inhibiendo su síntesis.

a) Reestructuración Aumento tamaño Reestructuración

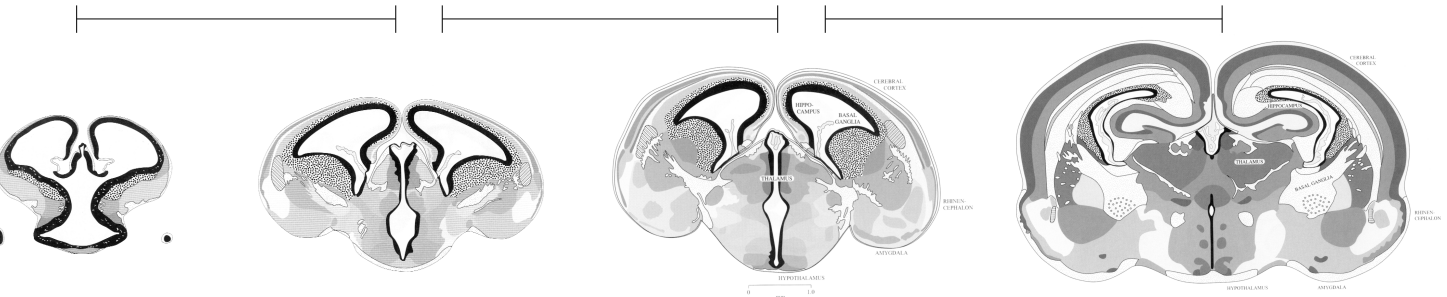

E 15

E 17

E 18

Po

b)

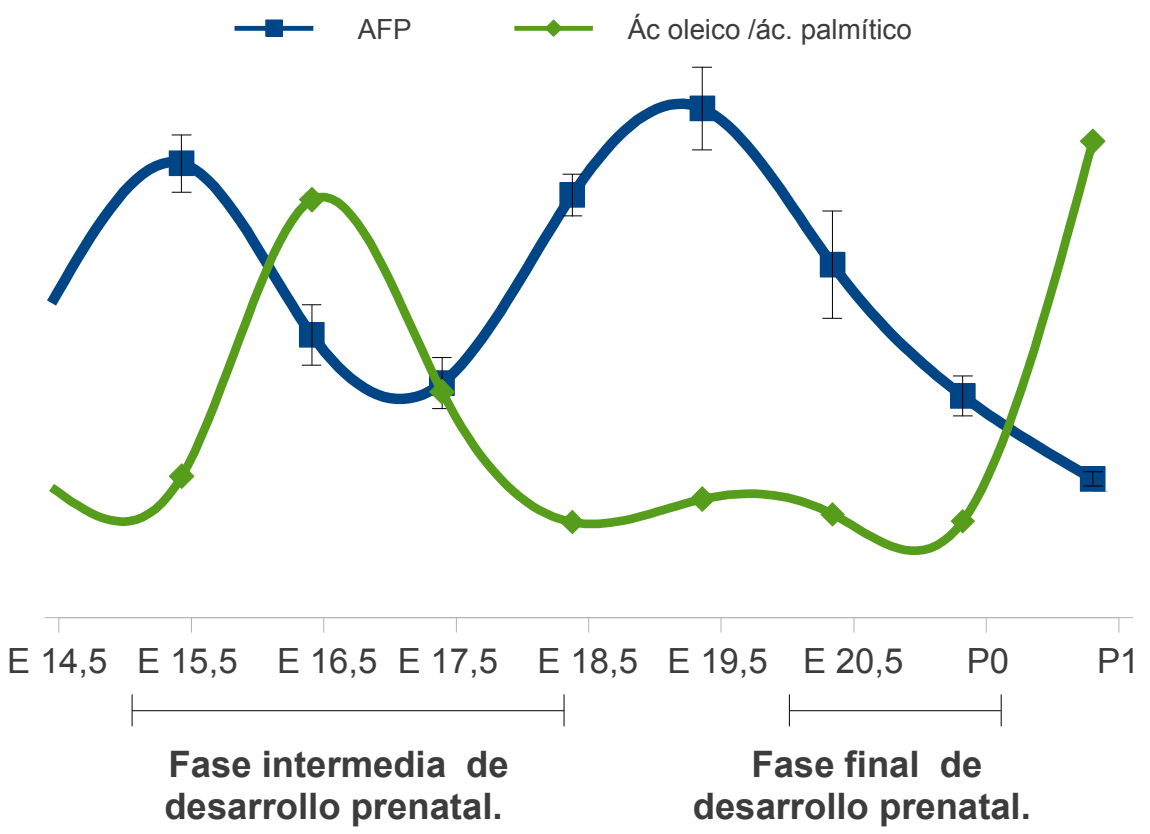

Esquema 18.- Relación entre el desarrollo del cerebro con su contenido en AFP y ácido oleico libre. a) Desde el momento del cierre del tubo neural (E11) el desarrollo prenatal del cerebro en la rata se puede dividir en una fase inicial de desarrollo (E11-E14), una fase intermedia (E15-E18) y una fase final (E20-E22) (Altman y Bayer 1994). b) La variación de los niveles de AFP y de síntesis de ácido oleico en el cerebro coincide con las transciones entre las diferentes etapas del desarrollo. Así el comienzo de la fase intermedia coincide con un pico en los niveles de AFP que es seguido por un aumento de la síntesis de ácido oleico. De la misma manera el comienzo de la fase final viene precedido por un pico de AFP seguido por un segundo pico en la síntesis de ácido oleico.

Cabe destacar que los picos de ácido oleico coinciden en el tiempo con los eventos de diferenciación a gran escala del cerebro. Así, el primer pico de ácido oleico se produce durante la etapa intermedia de desarrollo del cerebro durante la 


\section{Alejandro García García}

cuál se produce la aparición de las primeras estructuras en diferenciación (Altman y Bayer 1994). Obsérvese que durante este periodo (entre E15 y E17) se producen cambios importantes en las estructuras del cerebro (ver esquema 18a). Sin embargo, entre los días E17 y E18 la estructuración del cerebro es similar, pero se produce un aumento importante del volumen de las estructuras. Este cambio coincide con una disminución de la concentración de ácido oleico y el aumento de los niveles de AFP (ver esquema 18b). De igual manera, el segundo pico de olei$\mathrm{co}$, se produce el día 1 de vida postnatal, coincidiendo con el comienzo de los fenómenos de desarrollo postnatal del cerebro (ver esquema 18). Por tanto, la AFP podría estar regulando indirectamente los fenómenos de diferenciación del cerebro al inhibir la síntesis del ácido oleico en momentos concretos.

Desconocemos los mecanismos que pudieran relacionar la AFP con la síntesis del ácido oleico. En este sentido algunos autores han demostrado cómo el estradiol y su receptor, reprimen la expresión de la SCD-1, enzima limitante en el proceso de síntesis del ácido oleico y del factor de transcripción SREBP-1, el cual regula la síntesis de SCD-1 (Bryzgalova y col. 2006, 2008; Paquette y col. 2008). Tal y como se explica en la introducción, la AFP es el principal transportador de estradiol (Aussel y Masseyeff 1977; Nishi y col. 1991). Por tanto, resulta factible pensar que el transporte de estradiol por parte de la AFP podría estar inhibiendo la síntesis de ácido oleico.

Por otro lado, resulta importante destacar que la síntesis del ácido oleico se encuentra relacionada durante el desarrollo embrionario con la expresión de las proteínas marcadoras de desarrollo dendrítico y axonal, MAP-2 y GAP-43. De tal manera, en la fig. 2 se puede observar como el pico de ácido oleico en el cerebro coincide en el tiempo con el comienzo del aumento de los niveles de estas proteínas (fig.2). Posteriormente los niveles de MAP-2 y GAP-43 continúan aumentando de manera lineal, posiblemente debido a la presencia de otros factores neurotróficos. En conjunto, estos datos sugieren que el ácido oleico podría estar regulando los niveles de las proteínas marcadoras de diferenciación MAP-2 y GAP-43 también durante el desarrollo embrionario.

A su vez, el análisis inmunohistoquímico muestra la existencia de una relación 
inversa entre los niveles de AFP y GAP-43. En ese sentido, se observa como en E19,5, a pesar de coincidir en las mismas estructuras, ambas proteínas presentan un gradiente inverso de expresión. De tal manera, encontramos que en regiones más mediales de la subplaca, aparece una mayor señal para GAP-43, que en regiones laterales mientras que la distribución de la AFP es mayor en las regiones más laterales que en las mediales. Así mismo, en la región de materia blanca dorsal a la subplaca el marcaje es mayor para AFP y menor para GAP-43 mientras que en la región de materia blanca ventral a la subplaca y en la propia subplaca el marcaje es mayor para GAP-43 y menor para AFP (figs. 1b y c). A lo largo de la placa cortical, la señal de AFP se localiza en haces que rodean a las células corticales marcadas con GAP-43 de manera más evidente en la capa más dorsal (fig. 17d). Estas células corresponden con las células añadidas más recientemente a la placa cortical por migración radial (Gupta y col. 2002). La separación de estas proteínas resulta aún mas evidente en el día E15,5. De tal manera, la señal de GAP-43 aparece restringida a las zonas mas externas del cerebro mientras que la AFP se encuentra en las partes más internas de la amígdala, el hipotálamo y la región talámica (fig.18). Este gradiente de expresión inverso sugiere que la AFP podría estar inhibiendo la expresión de GAP-43 durante el desarrollo embrionario.

Es importante destacar como la AFP se encuentra presente en el cerebro en desarrollo en aquellas áreas implicadas en el establecimiento de las conexiones entre el tálamo y la corteza (figs. 11,12, 13 y esquema 19). Además, las regiones marcadas por la AFP parecen presentar una menor expresión de GAP-43. De hecho, parece factible sugerir que la AFP podría regular el establecimiento de las conexiones talamo-corticales (TAC) y cortico-talámicas (CTA) frenando el crecimiento axonal de estas conexiones (esquema 19). Así, vemos como la AFP se encuentra marcando fuertemente el núcleo reticular talámico (NRT), el hipotálamo y la amígdala el día E15,5. Numerosos autores han descrito la importancia de estas tres estructuras en el establecimiento de las conexiones entre el tálamo y la corteza.

Durante el desarrollo las conexiones TAC se extienden ventrálmente desde la región dorsal del tálamo (TI) hacia el NRT para después girar brúscamente evitando el hipotálamo. Seguidamente estas conexiones invaden la cápsula interna (Ci) 


\section{Alejandro García García}

deteniéndose ahí (en torno a E14,5). Así mismo las conexiones CTA extienden sus proyecciones primero lateralmente y posteriormente de manera ventral evitando la amígdala hasta llegar a la $\mathrm{Ci}$ en donde se detienen (en torno a E14,5). Posteriormente las conexiones TAC continúan su avance hacia la placa cortical acumulándose en la subplaca en donde esperarán en torno a dos o tres días antes de invadir la placa cortical (entre E19 y E20 en la rata). En ese sentido, en la figura 15 podemos observar como los axones marcados positivamente para GAP-43 parecen acumularse por debajo de la placa cortical en las inmediaciones de la subplaca, la cuál se encuentra marcada fuertemente para la AFP. Estas conexiones, emiten pequeñas proyecciones hacia la placa cortical (ver esquema 19b). Sin embargo, estas conexiones no invadirán la placa cortical hasta aproximadamente el momento del nacimiento, momento en el cuál se produce el crecimiento masivo de estas proyecciones atravesando las capas corticales VI y $\mathrm{V}$ hacia su destino principal en la capa cortical IV (ver esquema 19c). En ese momento, curiosamente, se produce una disminución drástica en los niveles de AFP en el cerebro (fig. 4). De hecho, los niveles máximos de AFP coinciden con los momentos de espera en el establecimiento de las conexiones TAC, en torno a E15, en las inmediaciones de la cápsula interna, y en torno a E19,5 en torno a la subplaca. (ver fig. 4 y esquemas 6 y 7 ; (Molnár y Cordery 1999; Jacobs y col. 2007)).

A la luz de estos datos, parece factible pensar que la AFP podría estar actuando como un inhibidor del crecimiento axonal en regiones y momentos concretos del desarrollo. Esta inhibición regularía el establecimiento de las conexiones TAC.

Además, cabe destacar que la reanudación del crecimiento axonal de las conexiones TAC y CTA tras sus correspondientes tiempos de espera, coinciden en el tiempo con el aumento de los niveles de ácido oleico libre (ver fig. 5). De tal manera, el ácido oleico podría estar actuando como un factor neurotrófico durante el desarrollo embrionario, estimulando el crecimiento de las conexiones entre el talámo y la corteza.

En definitiva, los niveles de expresión y la localización de la AFP en el cerebro durante el desarrollo embrionario, así como su relación con el factor neurotrófico y el marcador de diferenciación GAP-43, sugieren que la AFP podría estar regulan- 
a)

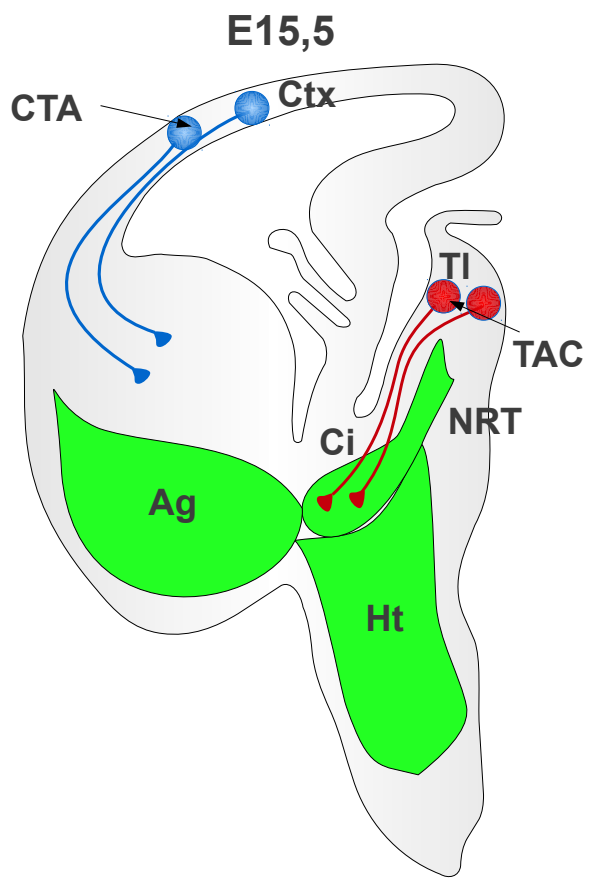

b) $\mathrm{E} 19,5$

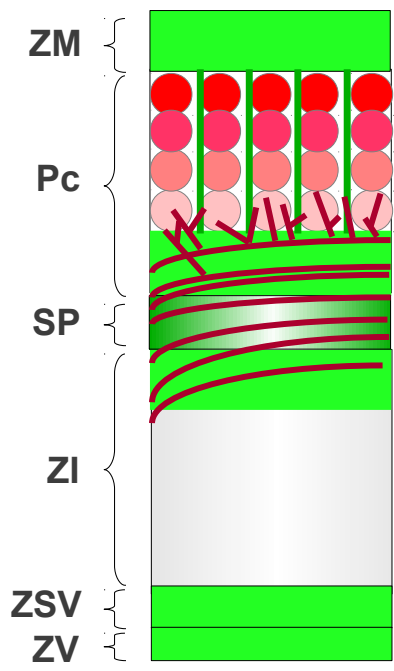

c)

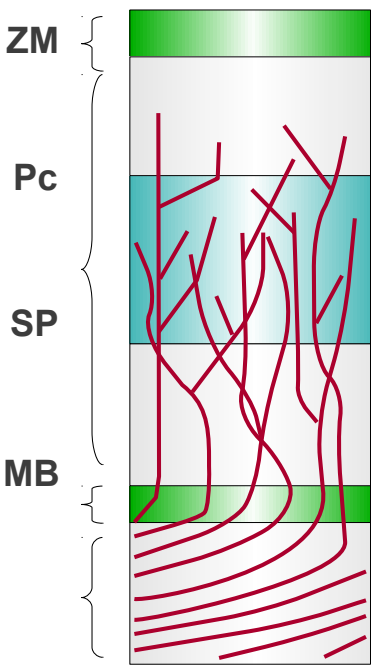

Esquema 19.- Relación entre la formación de las conexiones talamo-corticales y la localización de la AFP durante el desarrollo embrionario. En verde se muestran las estructuras en las que se detecta presencia de AFP en los días E15,5 y E19,5. a) La AFP se encuentra marcando la amígdala (Ag), el hipotálamo (Ht), la cápsula interna $(\mathrm{Ci})$ y el núcleo reticular talámico (NRT). En rojo se muestran las conexiones TAC. Estas conexiones se desarrollan en primer lugar ventrálmente desde el tálamo dorsal (TD). Posteriormente se desarrollarán lateralmente, evitando el hipotálamo, adrentándose en la cápsula interna donde dentendrán temporalmente su crecimiento. Posteriormente este crecimiento continuará hacia la región cortical, evitando en su trayectoria la amígdala. En azul se muestran las conexiones CTA, las cuáles migran primero ventrálmente y después lateralmente hacia la cápsula interna. b) En el día E19,5 puede observarse la presencia de AFP en la zona ventricular (ZV), la zona subventricular (ZSV), y en la zona marginal (ZM). Así mismo, puede observase la presencia de dos bandas de AFP que delimitan la subplaca (SP). En la subplaca se acumulan los axones de las conexiones TAC (en rojo oscuro), los cuáles no pueden atravesar la densa placa cortical (Pc). Así mismo desde la subplaca surgen haces marcados para la AFP que atraviesan la placa cortical, discurriendo entre los cuerpos celulares de las neuronas corticales, marcados de manera gradual para GAP-43.c) Tras el parto, los axones de las conexiones TAC invaden la placa cortical hacia su destino final principalmente en le capa cortical IV. Este fenómeno coincide con la desaparición de la AFP del cerebro.

\subsection{Obtención de la alfa-fetoproteína}

Puesto que nuestros resultados sugieren un posible papel de la AFP en el crecimiento axonal, decidimos investigar el papel de esta proteína en la diferenciación de neuronas en cultivo primario. Para ello necesitábamos obtener esta proteína en una forma adecuada para su utilización, es decir, AFP de rata correctamente plegada y procesada post-traduccionalmente. Puesto que no existe un prepara- 


\section{Alejandro García García}

do comercial de estas características, procedimos a su obtención a partir del medio de cultivo de células de hepatoma de rata (ver sección 3.2.4). Descartamos la obtención de la AFP mediante tecnología recombinante por la ausencia en estos preparados de modificaciones postraduccionales tales como las glicosilaciones. Así mismo descartamos la obtención de la AFP a partir de tejidos o plasma fetales al existir en estos materiales concentraciones muy elevadas de albúmina y otras proteínas.

El resultado de los diferentes pasos del proceso de purificación puede ser seguido en la figura 20. Así, en la figura 20a puede observarse como a medida que avanza el proceso de purificación se obtiene un purificado enriquecido en AFP que no posee albúmina.

El grado de pureza de la AFP obtenida fue determinado mediante electroforesis bidimensional. El resultado es una mancha de aproximadamente $65 \mathrm{kDa}$ y punto isoeléctrico en torno a 5 (fig. 21a). Tanto la transferencia tipo western, como la espectrometría de masas MALDI-TOF de esta proteína permitieron identificarla como AFP de rata (figura 22c). El resultado completo de la espectrometría MALDITOF para dos lotes diferentes de AFP puede encontrarse en el anexo. De esta manera determinamos que la AFP resultado del proceso de purificación tiene un grado de pureza de entre $77-90 \%$.

\subsection{Efecto de la alfa-fetoproteína sobre las neuronas}

Una vez obtenida una forma fisiológica de AFP de manera reproducible quisimos determinar el efecto de la AFP sobre las células del sistema nervioso durante el desarrollo, y concretamente sobre las neuronas, ya que tal y se ha descrito en la sección 5.3 la AFP parece regular el crecimiento axonal. Así, tal y como hemos señalado, la localización de la AFP presenta una relación inversa con la proteína marcadora de desarrollo GAP-43 y se encuentra relacionada con la parada del crecimiento de las proyecciones axonales y con la ausencia del factor neurotrófico ácido oleico. 
En primer lugar analizamos el efecto de la AFP sobre las neuronas en cultivo primario. Nuestros resultados muestran que la presencia de concentraciones crecientes de AFP en el medio de cultivo impide el crecimiento neuronal observándose una disminución de las ramificaciones celulares y un menor número de células (fig.23). De hecho, altas concentraciones de AFP producen una disminución significativa de la viabilidad neuronal (fig. 24) debido a un aumento de la apoptosis (fig. 29).

Algunos autores han destacado las particularidades de la estructura terciaria de la AFP, proponiéndose la existencia de una forma conformacional llamada de glóbulo fundido (Mizejewski 2001). De hecho, una ligera desnaturalización altera el correcto transporte de ligandos (Uversky y col. 1997). De tal manera, comprobamos como el efecto sobre el crecimiento neuronal es específico de la AFP en su conformación nativa ya que su desnaturalización, mediante el hervido de la proteína, suprime sus efectos (fig 27).

Los efectos de la AFP sobre el crecimiento celular se encuentran ampliamente descritos en la bibliografía (Wang y Xie 1998; Mizejewski 2001; Li, Li, He, y col. 2002; Li, Li, Yang, y col. 2002; Terentiev y Moldogazieva 2006). No obstante, estos efectos parecen ser dependientes del tipo celular estudiado (Dudich y col. 1998). En ese sentido, tal y como puede observarse en la figura 24 la presencia de AFP produce una disminución significativa del crecimiento de neuronas en cultivo primario. Sin embargo este efecto no es observado en astrocitos en cultivo primario, ni siquiera a concentraciones hasta diez veces superiores a la concentración máxima empleada para las neuronas (fig. 28).

Por otro lado, también se ha descrito que los efectos de la AFP sobre la regulación del crecimiento celular son dosis dependiente, promoviendo la proliferación a concentraciones moderadas y estimulando la apoptosis a altas concentraciones (Dudich y col. 1998, 2000; Wang y Xie 1998; Mizejewski 2001; Li, Li, Yang, y col. 2002; Li y col. 2004). Tal y como puede observarse en la figura 25, la AFP a bajas concentraciones produjo un aumento moderado en la incorporación de BrdU en neuronas en cultivo primario en presencia de AFP. La AFP en concentraciones similares parece tener un efecto promotor de la proliferación de neuronas producto- 


\section{Alejandro García García}

ras de la hormona liberadora de gonadotropina en cocultivos con explantes de hipotálamo, aunque estos resultados no han sido confirmados (Daikoku y Koide 1994). Por otro lado, tal y como hemos mencionado anteriormente, la presencia de altas concentraciones de AFP induce una disminución de la viabilidad neuronal debida a un aumento de la apoptosis (ver figs. 24 y 25). En este sentido, la AFP podría estar colaborando en el proceso de apoptosis neuronal fisiológica que tiene lugar durante el desarrollo del cerebro (de la Rosa y de Pablo 2000; Yeo y Gautier 2004; Boya y de la Rosa 2005).

Tal y como hemos podido observar la localización de la AFP se encuentra relacionada con zonas que presentan niveles bajos de la proteína responsable del crecimiento axonal GAP-43 (ver sección 4.1.6). En este sentido, la observación de los cambios morfológicos en los cultivos primarios de neuronas en presencia de AFP (fig. 23), sugiere un efecto inhibidor de esta proteína sobre el desarrollo de las ramificaciones neuronales. De tal manera quisimos determinar si la AFP pudiera llevar a cabo un efecto regulador sobre la neurodiferenciación. Para ello estudiamos, en neuronas sometidas a un agente diferenciador como es el complejo albúmina-acido oleico, el efecto de la AFP, empleando para ello un a concentración de AFP que no afectara la viabilidad celular. Nuestros resultados muestran que la AFP impide el efecto neutrófico del ácido oleico, caracterizado morfologicamente por la agrupación de los somas neuronales y la elongación de los axones (fig 30a). En esta línea, la presencia de AFP disminuye la expresión de las proteínas marcadoras de diferenciación neuronal MAP-2 y GAP-43 en neuronas (figs. 31 y 32). Estos resultados se encuentran en consonancia con la localización inversa de AFP y GAP-43 observada durante el desarrollo embrionario. De hecho, sugieren que la mayor concentración de AFP observada en algunas regiones del cerebro podría estar frenando la expresión de GAP-43 y por tanto el crecimiento axonal.

Tal y como se ha descrito anteriormente en nuestro grupo, en cultivos organotípicos de cerebros de P1, la albúmina induce la síntesis de GAP-43 y favorece la fasciculación axonal de las neuronas del estriado a través de la síntesis del ácido oleico por las células de la zona subventricular (Polo-Hernández y col. 2010). En el presente trabajo se observa por primera vez que también en cultivos organotípicos de E17,5 la albúmina favorece la formación de haces axonales y el aumento 
de la expresión de GAP-43 de manera similar al efecto ejercido por el complejo albúmina-ácido oleico (fig. 34). Sin embargo, la presencia de AFP en estos cultivos organotípicos de $E 17,5$ previno la formación de haces axonales y la expresión de GAP-43, indicando que la AFP inhibe la diferenciación neuronal producida por el ácido oleico.

Nuestros resultados sugieren que el crecimiento y diferenciación neuronales vienen determinados por un lado por el efecto de factores neurotróficos tales como la albúmina y el ácido oleico y por otro por el efecto de factores inhibidores del crecimiento neuronal como la AFP. El balance entre las concentraciones de estos factores regularía la neurogénesis y el desarrollo del cerebro en regiones y momentos concretos durante el desarrollo embrionario del cerebro. De tal manera, la alteración de este balance podría inducir fenotipos patológicos. En este sentido se ha descrito como en el síndrome de Down (SD) existe una disminución en los niveles de AFP y albúmina (Nelson 1961; Voigtlander y Vogel 1985; Kronquist y col. 1990). Así mismo, se han descrito, asociados a esta patología una disminución en los niveles de ácido grasos monoinsaturados en los fosfolípidos del cerebro (Shah 1979) y concretamente una disminución de los niveles de ácido oleico en la fosfatidil colina (Brooksbank y Martinez 1989). Se ha descrito el fenotipo del SD como un "retraso del desarrollo" (Rachidi y Lopes 2007). Resulta curioso destacar como en el modelo Ts16 de SD existe un defecto en la formación de la subplaca que produce el comienzo de la generación de las células de la placa cortical, antes del correcto establecimiento de la subplaca (Cheng y col. 2004). Cabe recordar que durante el desarrollo embrionario existen altas concentraciones de AFP en las inmediaciones de la subplaca. Si bien, por el momento, desconocemos los niveles de AFP en esta región en el SD, cabe esperar que estos sean menores. Así mismo, se ha demostrado en un modelo in vivo de hidrocefalía en ratas, una disminución de la neurogénesis como consecuencia de la acumulación de la concentración de proteínas del LCR en torno a E18 (Mashayekhi y col. 2002). Coincidiendo con estos resultados, el aumento de la concentración de proteínas del LCR en E14, provoca una disminución de la neurogénesis en E16 (Johansson y col. 2010). En estos modelos, las alteraciones en el desarrollo del cerebro pueden ser debidas a un aumento descontrolado en la concentración de AFP en el LCR y a 
una alteración del balance AFP-albúmina.

En conjunto, todos estos datos sugieren un efecto regulador de la alfa-fetoproteína sobre el desarrollo y diferenciación del cerebro durante la etapa embrionaria. Este efecto vendría marcado por el balance en las concentraciones de AFP, albúmina y ácido oleico. Nuestros resultados sugieren que, la AFP estaría ejerciendo un efecto inhibidor de la diferenciación neuronal promovida por el ácido oleico en regiones y periodos concretos del desarrollo embrionario. 
6 CONCLUSIONES 


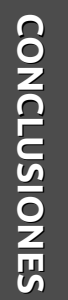


1. La alfa-fetoproteína y la albúmina se encuentran presentes en el cerebro durante el desarrollo embrionario de la rata. Los niveles de la AFP permanecen altos durante la mayor parte del desarrollo embrionario, mostrando dos picos en los días 15,5 y 19,5 de gestación y disminuyendo tras el parto. Los niveles de albúmina permanecen bajos durante el desarrollo embrionario, incrementando drásticamente en torno al día 18,5 de gestación.

2. Las concentraciones de ácido oleico en el cerebro en desarrollo presentan dos picos, uno entre los días 15,5 y 18,5 del desarrollo embrionario, y un segundo pico, en el día 1 de vida postnatal. Los aumentos en la relación ácido oleico/ácido palmítico coinciden en el tiempo con la disminución de los niveles de AFP durante el desarrollo del cerebro de la rata, lo que sugiere una posible inhibición de la síntesis de ácido oleico por pate de la AFP.

3. En el día 19,5 de desarrollo embrionario la AFP se encuentra localizada e principalmente en la zona ventricular, en las áreas de materia blanca que limitan con la subplaca, en la zona marginal y en la placa cortical. En estas circunstancias, la proteína marcadora de desarrollo axonal GAP-43 se encuentra en la zona marginal, marcando las células mas externas de la placa cortical y en los haces de fibras que rodean la subplaca, así como en la propia subplaca, y en el núcleo estriado. En ese momento, la AFP y GAP-43 colocalizan, únicamente, en la zona marginal y en algunos puntos situados entre la subplaca y la placa cortical. En general llama la atención que a medida que aumentan la AFP, disminuyen los niveles de GAP-43 y viceversa.

4. En el día 15,5 del desarrollo la AFP se localiza en áreas mas caudales y en las regiones que conformarán la amígdala, el tálamo y el hipotálamo. La presencia en el cerebro de la AFP es inversa a la densidad celular. De hecho, la diferente localización de la AFP y la GAP-43 resulta aún mas evidente en este momento del desarrollo, encontradose únicamente algunos puntos de colocalización en la zona marginal. Estos resultado sugieren que la AFP podría estar controlando el crecimiento y la orientación de los axones recién generados.

5. Hemos desarrollado un método de obtención y purificación de AFP de rata utilizando para ello células de hepatoma en cultivo. El análisis proteómico confir- 
mó la pureza de la AFP obtenida.

6. La adición de AFP en el cultivo primario de neuronas retrasa su crecimiento y diferenciación de manera dosis dependiente, pero no modifica el crecimiento de los astrocitos. A altas concentraciones, la AFP produce una disminución de la viabilidad neuronal induciendo la muerte por apoptosis. Nuestros resultados sugieren un efecto específico de la AFP sobre las neuronas.

7. La AFP inhibe la diferenciación neuronal inducida por el ácido oleico, caracterizada por el aumento de los niveles de las proteínas marcadoras de desarrollo axonal y dendrítico GAP-43 y MAP-2, respectivamente.

8. La AFP inhibe la diferenciación neuronal inducida por la albúmina y el ácido oleico en cultivos organotípicos de rodajas de cerebro de 17,5 días de gestación, inhibiendo el aumento de la expresión de GAP-43 y la fasciculación axonal.

Conclusión final: La alfa-fetoproteína está presente en el cerebro durante el desarrollo y su localización esta relacionada con regiones en las que se detiene el crecimiento axonal y en las que existe una menor expresión de GAP-43. Nuestros resultados sugieren que la AFP podría estar ejerciendo un efecto inhibidor sobre la diferenciación neuronal promovida por el ácido oleico en regiones muy concretas del cerebro en momentos clave del desarrollo embrionario. 
7 BIBLIOGRAFÍA 
Abelev, G.I. y Eraiser, T.L. (1999) Cellular aspects of alpha-fetoprotein reexpression in tumors. Seminars in Cancer Biology, 9, 95-107.

Aggarwal, S. (2010) Targeted cancer therapies. Nature reviews. Drug discovery, 9, 427-8.

Ahn, S.M.S.-M., Byun, K., Cho, K., Kim, J.Y.J.Y., Yoo, J.S.J.S., Kim, D., Paek, S.H.S.H., Kim, S.U., Simpson, R.J.R.J., y Lee, B. (2008) Human microglial cells synthesize albumin in brain. PloS one, 3, e2829.

Alava, M. a, Iturralde, M., Gonzalez, B., y Piñeiro, a (1999) Fatty acid desaturation: effect of alphafetoprotein on alpha-linolenic acid conversion by fetal rat hepatocytes. Prostaglandins, leukotrienes, and essential fatty acids, $\mathbf{6 0}$, 209-15.

Alberts, B., Bray, D., Lewis, J., Raff, M., Roberts, K., y Watson, J.D. (1996) Biología Molecular De La Célula. Garland Publishing, Inc., Barcelona.

Ali, M. y Sahib, M.K. (1983) Changes in alpha-fetoprotein and albumin synthesis rates and their levels during fetal and neonatal development of rat brain. Developmental Brain Research, 6, 314-317.

Ali, M., Kaul, H.K., y Sahib, M.K. (1981) Ontogeny and distribution of alpha-fetoprotein in feto-neonatal rat brain. Brain research, 227, 618-21.

Ali, M., Mujoo, K., y Sahib, M.K. (1982) Synthesis and secretion of alphafetoprotein and albumin by newborn rat brain cells in culture. Developmental Brain Research, 6, 47-55.

Allen, S.H., Bennett, J.A., Mizejewski, G.J., Andersen, T.T., Ferraris, S., y Jacobson, H.I. (1993) Purification of alpha-fetoprotein from human cord serum with demonstration of its antiestrogenic activity. Biochim Biophys Acta, 1202, $135-42$.

Altman, J. y Bayer, S.A. (1979) Development of the diencephalon in the rat. V. Thymidine-radiographic observations on internuclear and intranuclear gradients in the thalmus. The Journal of Comparative Neurology, 188, 473499. 
Altman, J. y Bayer, S.A. (1994) Atlas of Prenatal Rat Brain Development, 1st edn. CRC Press.

Altman, J. y Bayer, S.A. (2012) Neuron Development (documento web). Disponible en: http://neurondevelopment.org/ (fecha de consulta: 10-feb2012)

Anel, a, Calvo, M., Naval, J., Iturralde, M., Alava, M. a, y Piñeiro, a (1989) Interaction of rat alpha-fetoprotein and albumin with polyunsaturated and other fatty acids: determination of apparent association constants. FEBS letters, 250, 22-4.

Anel, A., Naval, J., González, B., Torres, J.M., Mishal, Z., Uriel, J., y Piñeiro, A. (1990) Fatty acid metabolism in human lymphocytes. I. Time-course changes in fatty acid composition and membrane fluidity during blastic transformation of peripheral blood lymphocytes. Biochimica et biophysica acta, 1044, 323-31.

Aoyagi, Y., Ikenaka, T., y Ichida, F. (1978) Copper(II)-binding ability of human alpha-fetoprotein. Cancer research, 38, 3483-6.

Aoyagi, Y., Ikenaka, T., y Ichida, F. (1979) alpha-Fetoprotein as a carrier protein in plasma and its bilirubin-binding ability. Cancer research, 39, 3571-4.

Arias, C., Becerra-Garcia, F., Arrieta, I., y Tapia, R. (1998) The protein phosphatase inhibitor okadaic acid induces heat shock protein expression and neurodegeneration in rat hippocampus in vivo. Exp Neurol, 153, 242-54.

Assémat, E., Vinot, S., Gofflot, F., Linsel-Nitschke, P., Illien, F., Châtelet, F., Verroust, P., Louvet-Vallée, S., Rinninger, F., y Kozyraki, R. (2005) Expression and Role of Cubilin in the Internalization of Nutrients During the Peri-Implantation Development of the Rodent Embryo Biology of Reproduction , 72 , 10791086.

Attardi, B. y Ruoslahti, E. (1976) Foetoneonatal oestradiol-binding protein in mouse brain cytosol is alpha foetoprotein. Nature, 263, 685-687.

Aussel, C. y Masseyeff, R. (1977) Binding of estrogens to molecular variants of rat alpha-fetoprotein. FEBS letters, 8, 363-365. 
Aussel, C. y Masseyeff, R. (1983) Inhibition of rat alpha-fetoprotein-estrogen interaction by adult rat ovarian extracts-role of unsaturated fatty acids. Journal of Steroid Biochemistry, 19, 1219-1222.

Aussel, C., Uriel, J., y Mercier-Bodard, C. (1974) Rat alpha-fetoprotein: isolation, characterization and estrogen-binding properties. Biochimie, 14311437.

Avila, J., Dominguez, J., Diaz-Nido, J., y Ávila, J. (1994) Regulation of microtubule dynamics by microtubule-associated protein expression and phosphorylation during neuronal development. Int J Dev Biol, 38, 13-25.

Avila-Martin, G., Galan-Arriero, I., Gómez-Soriano, J., y Taylor, J. (2011) Treatment of rat spinal cord injury with the neurotrophic factor albumin-oleic acid: translational application for paralysis, spasticity and pain. PloS one, $\mathbf{6}$, e26107.

Bakker, J., Mees, C.D., Douhard, Q., Balthazart, J., Gabant, P., Szpirer, J., Szpirer, C., y De Mees, C. (2006) Alpha-fetoprotein protects the developing female mouse brain from masculinization and defeminization by estrogens. Nature neuroscience, 9, 220-6.

Baltanás, F.C., Weruaga, E., Valero, J., Recio, J.S., y Alonso, J.R. (2009) Albumin attenuates DNA damage in primary-cultured neurons. Neuroscience Letters, 450, 23-26.

Barbin, G., Pollard, H., Gaiarsa, J.L., y Ben-Ari, Y. (1993) Involvent of GABAA receptors in the outgrowth of cultured hippocampal neurons. Neurosci. Lett., 152, 150-154.

Baskin, D.G., Figlewicz, D.P., Woods, S.C., Porte Jr., D., y Dorsa, D.M. (1987) Insulin in the brain. Ann. Rev. Physiol., 49, 335-347.

Bayer, S.A. (1985) The development of the central nervous system. En Wiggins, R.C., McCandless, D.W., y Enna, S.J. (eds), Development Neurochemistry. University of Texas Press, Austin, págs. 18-56.

Bayer, S.A. (1995) Neurogenesis and Neuronal Migration. En Paxinos, G. (ed), The Rat Nervous System, 2nd edn. Academic Press, Sydney, págs. 
1041-1076.

Bayer, S.A. y Altman, J. (1990) Development of layer I and the subplate in the rat neocortex. Experimental neurology, 107, 48-62.

Bayer, S.A. y Altman, J. (1991) Neocortical Development. Raven Press.

Becker, J.E., de Nechaud, B., y Potter, V.R. (1976) Two new rat hepatoma cell lines for studying the unbalanced blocked ontogeny hypothesis. En Fishman W.H.;Sell, S. ;Protein. I.R.G. for C. (ed), Onco-developmental Gene Expression. Academic Press, New York, NY,, págs. pp. 259-270.

Belayev, L., Liu, Y., Zhao, W., Busto, R., y Ginsberg, M.D. (2001) Human albumin therapy of acute ischemic stroke: marked neuroprotective efficacy at moderate doses and with a broad therapeutic window. Stroke, 32, 553-60.

Benassayag, C., Savu, L., Vallette, G., Delorme, J., y Nunez, E.A. (1979) Relations between fatty acids and oestrogen binding properties of pure rat alpha1-foetoprotein. Biochimica et Biophysica Acta (BBA) - General Subjects, 587, 227-237.

Benassayag, C., Vallette, G., Delorme, J., Savu, L., y Nunez, E.A. (1980) High affinity of nonesterified polyunsaturated fatty acids for rat alpha-fetoprotein (AFP). Oncodevelopmental biology and medicine: the journal of the International Society for Oncodevelopmental Biology and Medicine, 1, 27-36.

Bennett, J.A., DeFreest, L., Anaka, I., Saadati, H., Balulad, S., Jacobson, H., y Andersen, T. (2006) AFPep: an anti-breast cancer peptide that is orally active. Breast Cancer Research and Treatment, 98, 133-141.

Bennett, J.A., Zhu, S., Pagano-Mirarchi, A., Kellom, T.A., Jacobson, H.I., Jacobson, I., y Kellom, A. (1998) Alpha-fetoprotein derived from a human hepatoma prevents growth of estrogen-dependent human breast cancer xenografts. Clinical Cancer Research: An Official Journal of the American Association for Cancer Research, 4, 2877-84.

Benowitz, L.I. y Routtenberg, A. (1997) GAP-43: an intrinsic determinant of neuronal development and plasticity. Trends in Neurosciences, 20, 84-91. 
Bento-Abreu, A., Tabernero, A., y Medina, J.M. (2007) Peroxisome Proliferator-Activated Receptor-alpha is required for the neurotrophic effect of oleic acid in neurons. Journal of Neurochemistry, 103, 871-881.

Bento-Abreu, A., Velasco, A., Polo-Hernandez, E., Lillo, C., Kozyraki, R., Tabernero, A., y Medina, J.M. (2009) Albumin endocytosis via megalin in astrocytes is caveola- and Dab-1 dependent and is required for the synthesis of the neurotrophic factor oleic acid. J Neurochem, 111, 49-60.

Bento-Abreu, A., Velasco, A., Polo-Hernández, E., Pérez-Reyes, P.L., Tabernero, A., Medina, J.M., Polo-Hernandez, E., y Perez-Reyes, P.L. (2008) Megalin is a receptor for albumin in astrocytes and is required for the synthesis of the neurotrophic factor oleic acid. Journal of Neurochemistry, 106, 114959.

Bhattacharya, A.A., Grüne, T., y Curry, S. (2000) Crystallographic analysis reveals common modes of binding of medium and long-chain fatty acids to human serum albumin. Journal of Molecular Biology, 303, 721-732.

Blanquart, C., Mansouri, R., Paumelle, R., Fruchart, J.C., Staels, B., y Glineur, C. (2004) The protein kinase C signaling pathway regulates a molecular switch between transactivation and transrepression activity of the peroxisome proliferator-activated receptor alpha. Mol Endocrinol, 18, 1906-18.

Bligh, E.G. y Dyer, W.J. (1959) A rapid method of total lipid extraction and purification. Can J Biochem Physiol, 37, 911-7.

Boya, P. y de la Rosa, E.J. (2005) Cell death in early neural life. Birth defects research. Part C, Embryo today: reviews, 75, 281-93.

Bradford, M.M. (1976) A rapid and sensitive method for the quantitation of microgram quantities of protein utilizing the principle of protein-dye binding. Anal Biochem, 72, 248-54.

Braga-Neto, P., Dutra, L.A., Pedroso, J.L., y Barsottini, O.G.P. (2010) Alpha-fetoprotein as a biomarker for recessive ataxias. Arquivos De Neuro-Psiquiatria, 68, 953-955.

Breuer, S., Pech, K., Buss, A., Spitzer, C., Ozols, J., Hol, E.M., Heussen, 
N., Noth, J., Schwaiger, F.-W.W., y Schmitt, A.B. (2004) Regulation of stearoyl-CoA desaturase-1 after central and peripheral nerve lesions. BMC Neuroscience, $\mathbf{5}, 15$.

Brooksbank, B. y Martinez, M. (1989) Lipid abnormalities in the brain in adult Down's syndrome and Alzheimer's disease. Molecular and Chemical Neuropathology, 11, 157-185.

Bryzgalova, G., Gao, H., Ahren, B., Zierath, J.R.R., Galuska, D., Steiler, T.L.L., Dahlman-Wright, K., Nilsson, S., Gustafsson, J.-Å.J.-Å., Efendic, S., y Khan, A. (2006) Evidence that oestrogen receptor- $\alpha$ plays an important role in the regulation of glucose homeostasis in mice: insulin sensitivity in the liver. Diabetologia, 49, 588-597.

Bryzgalova, G., Lundholm, L., Portwood, N., Gustafsson, J.-A., Khan, A., Efendic, S., y Dahlman-Wright, K. (2008) Mechanisms of antidiabetogenic and body weight-lowering effects of estrogen in high-fat diet-fed mice. American Journal of Physiology. Endocrinology and Metabolism, 295, E904-912.

Bulloch, A.G.M. (1987) Somatostatin enhances neurite outgrowth and electrical coupling of regenerating neurons in Helisoma. Brain Res., 412, 617.

Bélanger, L., Roy, S., y Allard, D. (1994) New albumin gene 3' adjacent to the alpha 1-fetoprotein locus. The Journal of biological chemistry, 269, 54814.

Calvo, M., Naval, J., Lampreave, F., Uriel, J., Piñeiro, A., y Pineiro, A. (1988) Fatty acids bound to alpha-fetoprotein and albumin during rat development. Biochimica et Biophysica Acta (BBA)-Lipids and Lipid Metabolism, 959, 238-246.

Carlini, P., Ferranti, P., Polizio, F., Ciriolo, M.R., y Rotilio, G. (2007) Purification and characterization of Alpha-Fetoprotein from the human hepatoblastoma HepG2 cell line in serum-free medium. Biometals, 20, 869-78.

De Carlos, J.A. y O'Leary, D.D. (1992) Growth and targeting of subplate axons and establishment of major cortical pathways. The Journal of neuros- 
cience, 12, 1194-1211.

De Carlos, J.A., López-Mascaraque, L., y Valverde, F. (1996) Dynamics of Cell Migration from the Lateral Ganglionic Eminence in the Rat. The Journal of Neuroscience, 16, 6146-6156.

Carro, E., Spuch, C., Trejo, J.L., Antequera, D., y Torres-Aleman, I. (2005) Choroid plexus megalin is involved in neuroprotection by serum insulin-like growth factor I. J Neurosci, 25, 10884-93.

Catalano, S.M. y Shatz, C.J. (1998) Activity-Dependent Cortical Target Selection by Thalamic Axons Science , 281 , 559-562.

Cavanagh, M.E. y Warren, A. (1985) The distribution of native albumin and foreign albumin injected into lateral ventricles of prenatal and neonatal rat forebrains. Anat Embryol (Berl), 172, 345-351.

Caviness, V.S.J. (1989) Normal development of cerebral neocortex. En Evrard, P. y Minkowski, A. (eds), Developmental Neurobiology. Vevey, Raven Press, New York, págs. 1-10.

Caviness, V.S.J. y Takahashi, T. (1995) Proliferative events in the cerebral ventricular zone. Brain and Development, 17, 159-163.

Chen, Y. y Leong, S.S.J. (2009) Adsorptive refolding of a highly disulfidebonded inclusion body protein using anion-exchange chromatography. Journal of Chromatography A, 1216, 4877-4886.

Cheng, A., Haydar, T.F., Yarowsky, P.J., y Krueger, B.K. (2004) Concurrent generation of subplate and cortical plate neurons in developing trisomy 16 mouse cortex. Developmental neuroscience, 26, 255-65.

Chiaramello, A., Neuman, T., Peavy, D.R., y Zuber, M.X. (1996) The GAP43 gene is a direct downstream target of the basic helix-loop- helix transcription factors. J Biol Chem, 271, 22035-43.

Cohen, S. (1960) Purification of a nerve-growth promoting protein from the mouse salivary gland and its neuro-cytotoxic antiserum. Proceedings of the National Academy of Sciences, 46, 302-311. 
Cowan, W.M. (1987) Desarrollo del cerebro. En Hubel, D.H. (ed), El Cerebro. Prensa Científica, Barcelona, págs. 69-81.

Cunnane, S.C., Schneider, J.A., Tangney, C., Tremblay-Mercier, J., Fortier, M., Bennett, D.A., y Morris, M.C. (2012) Plasma and Brain Fatty Acid Profiles in Mild Cognitive Impairment and Alzheimer's Disease. Journal of Alzheimer's disease: $J A D$,.

Curry, S., Brick, P., y Franks, N.P. (1999) Fatty acid binding to human serum albumin: new insights from crystallographic studies. Biochimica et Biophysica Acta (BBA)-Molecular and Cell Biology of Lipids, 1441, 131-140.

Cáceres, A., Banker, G., Steward, O., Binder, L., y Payne, M. (1984) MAP2 is localized to the dendrites of hippocampal neurons which develop in culture. Developmental Brain Research, 13, 314-318.

Cáceres, A., Banker, G.A., y Binder, L. (1986) Immunocytochemical localization of tubulin and microtubule-associated protein 2 during the development of hippocampal neurons in culture. J Neurosci, 6, 714-22.

Daikoku, S. y Koide, I. (1994) In Vitro Development of Placode-Derived LHRH Neurons: Possible Involvement of a-Fetoprotein. Hormones and Behavior, 28, 328-335.

Dani, J.W., Armstrong, D.M., y Benowitz, L.I. (1991) Mapping the development of the rat brain by GAP-43 immunocytochemistry. Neuroscience, 40, 277-287.

Dauphinée, M.J. y Mizejewski, G.J. (2002) Human alpha-fetoprotein contains potential heterodimerization motifs capable of interaction with nuclear receptors and transcription/growth factors. Medical hypotheses, 58, 453-61.

Davson, H. y Segal, M.B. (1996) Physiology of the CSF and Blood-brain Barriers. CRC press Boca Raton:

Deacon, T.W. (1990) Problems of ontogeny and phylogeny in brain-size evolution. International Journal of Primatology, 11, 237-282.

Deacon, T.W. (1997) What Makes the Human Brain Different? Annual Re- 
view of Anthropology, 26, 337-357.

Deane, R., Wu, Z., Sagare, A., Davis, J., Du Yan, S., Hamm, K., Xu, F., Parisi, M., LaRue, B., Hu, H.W., Spijkers, P., Guo, H., Song, X., Lenting, P.J., Van Nostrand, W.E., y Zlokovic, B.V. (2004) LRP/amyloid beta-peptide interaction mediates differential brain efflux of Abeta isoforms. Neuron, 43, 33344.

Dinsmore, J.H. y Solomon, F. (1991) Inhibition of MAP-2 expression affects both morphological and cell division phenotypes of neuronal differentiation. Cell, 64, 817-826.

Dudich, E., Semenkova, L., Dudich, I., Gorbatova, E., Tochtamisheva, N., Tatulov, E., Nikolaeva, M., y Sukhikh, G. (1999) Alpha-fetoprotein causes apoptosis in tumor cells via a pathway independent of CD95, TNFR1 and TNFR2 through activation of caspase-3-like proteases. Eur J Biochem, 266, 750-761.

Dudich, E., Semenkova, L., Gorbatova, E., Dudich, I., Khromykh, L., Tatulov, E., Grechko, G., y Sukhikh, G. (1998) Growth-regulative activity of human alpha-fetoprotein for different types of tumor and normal cells. Tumour Biology: the Journal of the International Society for Oncodevelopmental Biology and Medicine, 19, 30-40.

Dudich, E.I., Semenkova, L., Dudich, I.V., Nikolaeva, M.A., Gorbatova, E.A., Khromykh, L.M., Grechko, G.K., y Sukhikh, G.T. (2000) Alpha-Fetoprotein-induced apoptosis of cancer cells. Bulletin of Experimental Biology and Medicine, 130, 1127-1133.

Duggleby, R.G. y Northrop, D.B. (1989) Quantitative analysis of absorption spectra and application to the characterization of ligand binding curves. Cellular and Molecular Life Sciences, 45, 87-92.

Dziegielewska, K.M., Evans, C. a, Lai, P.C., Lorscheider, F.L., Malinowska, D.H., Møllgård, K., y Saunders, N.R. (1981) Proteins in cerebrospinal fluid and plasma of fetal rats during development. Developmental biology, 83, 193200. 
Dziegielewska, K.M., Evans, C.A., Lorscheider, F.L., Malinowska, D.H., Møllgård, K., Reynolds, M.L., y Saunders, N.R. (1981) Plasma proteins in fetal sheep brain: blood-brain barrier and intracerebral distribution. J. Physiol., 318, 239-250.

Dziegielewska, K.M., Knott, G.W., y Saunders, N.R. (2000) The nature and composition of the internal environment of the developing brain. Cellular and molecular neurobiology, 20, 41-56.

Dziegielewska, K.M., Saunders, N.R., Schejter, E.J., Zakut, H., Zevin-Sonkin, D., Zisling, R., y Soreq, H. (1986) Synthesis of plasma proteins in fetal, adult, and neoplastic human brain tissue. Developmental biology, 115, 93104.

Ek, C.J., Dziegielewska, K.M., Habgood, M.D., y Saunders, N.R. (2011) Barriers in the developing brain and Neurotoxicology. Neurotoxicology,.

Elliott, K.A.C. (1969) The use of brain slices. En Lajtha, A. (ed), Handbook of Neurochemistry Vol III. Plenum Press, New York, págs. 103-114.

Farkas, L.M. y Huttner, W.B. (2008) The cell biology of neural stem and progenitor cells and its significance for their proliferation versus differentiation during mammalian brain development. Current Opinion in Cell Biology, 20, 707-715.

Fietz, S. a y Huttner, W.B. (2011) Cortical progenitor expansion, self-renewal and neurogenesis-a polarized perspective. Current Opinion in Neurobiology, 21, 23-35.

Fishman, P.S., Farrand, D.A., y Kristt, D.A. (1990) Internalization of plasma proteins by cerebellar purkinje cells. 100, 43-49.

Gabant, P., Forrester, L., Nichols, J., Van Reeth, T., De Mees, C., Pajack, B., Watt, A., Smitz, J., Alexandre, H., Szpirer, C., y Szpirer, J. (2002) Alpha-fetoprotein, the major fetal serum protein, is not essential for embryonic development but is required for female fertility. Proceedings of the National Academy of Sciences of the United States of America, 99, 12865-70.

Galazo, M.J., Martinez-Cerdeño, V., Porrero, C., y Clascá, F. (2008) Embr- 
yonic and postnatal development of the layer l-directed ("matrix") thalamocortical system in the rat. Cerebral cortex (New York, N.Y. : 1991), 18, 344-63.

Gato, A. y Desmond, M.E. (2009) Why the embryo still matters: CSF and the neuroepithelium as interdependent regulators of embryonic brain growth, morphogenesis and histiogenesis. Developmental Biology, 327, 263-272.

Ghosh, A., Antonini, A., McConnell, S.K., y Shatz, C.J. (1990) Requirement for subplate neurons in the formation of thalamocortical connections. Nature, 347, 179-181.

Gillespie, J.R. y Uversky, V.N. (2000) Structure and function of a-fetoprotein: a biophysical overview. Biochimica et Biophysica Acta (BBA)-Protein Structure and Molecular Enzymology, 1480, 41-56.

Ginsberg, M.D., Palesch, Y.Y., Martin, R.H., Hill, M.D., Moy, C.S., Waldman, B.D., Yeatts, S.D., Tamariz, D., Ryckborst, K., y Investigators, for the A. (2011) The Albumin in Acute Stroke (ALIAS) Multicenter Clinical Trial Stroke, $42,119-127$.

Gohlke, J.M., Griffith, W.C., y Faustman, E.M. (2004) The role of cell death during neocortical neurogenesis and synaptogenesis: implications from a computational model for the rat and mouse. Developmental Brain Research, 151, 43-54.

Goldman, B. (2009) Gray matters: Unsung brain cells determine function of neurons, researchers discover (documento web). Stanford University School of Medicine, News,. Disponible en: http://med.stanford.edu/ism/2009/september/glia-0921.html (fecha de consulta: 06-mar-2012)

Gottlicher, M., Widmark, E., Li, Q., y Gustafsson, J.A. (1992) Fatty acids activate a chimera of the clofibric acid-activated receptor and the glucocorticoid receptor. Proc Natl Acad Sci U S A, 89, 4653-7.

Granda, B., Tabernero, A., Tello, V., y Medina, J.M. (2003) Oleic acid induces GAP-43 expression through a protein kinase C-mediated mechanism that is independent of NGF but synergistic with NT-3 and NT-4/5. Brain Res, 988, 1-8. 
Grimm-Jorgensen, Y. (1987) Somatostatin and calcitonin stimulate neurite regeneration of molluscan neurons in vitro. Brain Res., 403, 121-126.

Gupta, A., Tsai, L.H., y Wynshaw-Boris, A. (2002) Life is a journey: a genetic look at neocortical development. Nature Reviews Genetics, 3, 342-355.

Gurr, M.I., Harwood, J.L., y Frayn, K.N. (2002) Lipid Biochemistry. Blackwell Science, Cornwall.

Götz, M. y Huttner, W.B. (2005) The cell biology of neurogenesis. Nature Reviews. Molecular Cell Biology, 6, 777-788.

Habgood, M., Sedgwick, J., Dziegielewska, K., y Saunders, N.R. (1992) A developmentally regulated blood-cerebrospinal fluid transfer mechanism for albumin in immature rats. The Journal of physiology, 456, 181.

Hamburger, V. y Levi-Montalcini, R. (1949) Proliferation, differentiation and degeneration in the spinal ganglia of the chick embryo under normal and experimental conditions. Journal of Experimental Zoology, 111, 457-501.

Hamon, M., Bourgoin, S., Chanez, C., y De Vitry, F. (1989) Do serotonin and other neurotransmitters exert a trophic influence on the immature brain? En Evrard, P. y Minkowski, A. (eds), Developmental Neurobiology. Vevey, Raven Press, New York, págs. 171-183.

Hatten, M.E. y Mason, C.A. (1986) Neuron-astroglia interactions in vitro and in vivo. Trends Biochem. Sci., 9, 168-174.

Hayashi, M. (1992) Ontogeny of some neuropeptides in the primate brain. Prog Neurobiol, 38, 231-260.

He, X.M. y Carter, D.C. (1992) Atomic structure and chemistry of human serum albumin. Nature, 358, 209-215.

Herschkowitz, N. (1988) Brain development in the fetus, neonate and infant. Biol. Neonate, 54, 1-19.

Herz, J. y Chen, Y. (2006) Reelin, lipoprotein receptors and synaptic plasticity. Nature reviews. Neuroscience, 7, 850-9.

Houlgatte, R., Mallat, M., Brachet, P., y Prochiantz, A. (1989) Secretion of 
nerve growth factor in cultures of glial cells and neurons derived from different regions of the mouse brain. J. Neurosci. Res., 24, 143-152.

Huang, T., Hoffman, B., Meschino, W., Kingdom, J., y Okun, N. (2010) Prediction of adverse pregnancy outcomes by combinations of first and second trimester biochemistry markers used in the routine prenatal screening of Down syndrome. Prenatal Diagnosis, 30, 471-477.

Hughes, E.H.H., Schut, H.A.J.A., y Thorgeirsson, S.S.S. (1982) Effects of hexamethylene bisacetamide on alpha-fetoprotein, albumin, and transferrin production by two rat hepatoma cell lines. In Vitro Cellular \& Developmental Biology-Plant, 18, 157-164.

Iturralde, M., Alava, M.A.A., González, B., Anel, A., Piñeiro, A., Gonzalez, B., y Pineiro, A. (1991) Effect of alpha-fetoprotein and albumin on the uptake of polyunsaturated fatty acids by rat hepatoma cells and fetal rat hepatocytes. Biochimica et biophysica acta, 1086, 81-8.

Ivins, J.K. y Pittman, R.N. (1989) Growth cone-growth cone interactions in cultures of rat sympathetic neurons. Dev. Biol., 135, 147-157.

Jacobs, E.C., Campagnoni, C., Kampf, K., Reyes, S.D., Kalra, V., Handley, V., Xie, Y.-Y., Hong-Hu, Y., Spreur, V., Fisher, R.S., y Campagnoni, A.T. (2007) Visualization of corticofugal projections during early cortical development in a tau-GFP-transgenic mouse. The European journal of neuroscience, 25, 17-30.

Jacobsen, M., Lassen, L.C., y Møllgård, K. (1984) Immunohistochemical evidence for intracellular localization of plasma proteins in CNS and some neural crest derivatives in human embryos. Tumour Biology: The Journal of the International Society for Oncodevelopmental Biology and Medicine, 5, 5360.

Jacobson, H.I., Bennett, J.A., y Mizejewski, G.J. (1990) Inhibition of estrogen-dependent breast cancer growth by a reaction product of alpha-fetoprotein and estradiol. Cancer research, 50, 415-20.

Johansson, P.A., Dziegielewska, K.M., Ek, C.J., Habgood, M.D., Liddelow, S.A., Potter, A.M., Stolp, H.B., y Saunders, N.R. (2006) Blood-CSF barrier 


\section{Alejandro García García}

function in the rat embryo. The European Journal of Neuroscience, 24, 65-76.

Johansson, P.A., Dziegielewska, K.M., Liddelow, S.A., y Saunders, N.R. (2008) The blood-CSF barrier explained: when development is not immaturity. BioEssays: News and Reviews in Molecular, Cellular and Developmental Biology, 30, 237-248.

Johansson, P.A., Simeone, A., y Götz, M. (2010) The choroid plexus: A gate for signalling into the brain. En 7th FENS Forum. Amsterdam.

Juurlink, B.H.J. y Devon, R.M. (1990) Macromolecular translocation-a possible function of astrocytes. Brain Res., 533, 73-77.

Kajiyama, Y., Tian, J., y Locker, J. (2006) Characterization of distant enhancers and promoters in the albumin-alpha-fetoprotein locus during active and silenced expression. The Journal of biological chemistry, 281, 30122-31.

Kalil, R.E. (1990) Formación de sinapsis durante el desarrollo del cerebro. Investigación y Ciencia, Febrero, 26-34.

Kandel, E.R., Schwartz, J.H., y Jessell, T.M. (2001) Principios De Neurociencia. McGraw-Hill/Interamericana, Madrid.

Kanold, P.O. y Luhmann, H.J. (2010) The subplate and early cortical circuits. Annual review of neuroscience, 33, 23-48.

Khan, W.A., Blobe, G.C., y Hannun, Y.A. (1992) Activation of protein kinase $C$ by oleic acid. J. Biol. Chem., 267, 3605-3612.

Kounnas, M.Z., Haudenschild, C.C., Strickland, D.K., y Argraves, W.S. (1994) Immunological localization of glycoprotein 330, low density lipoprotein receptor related protein and $39\{\mathrm{kDa}\}$ receptor associated protein in embryonic mouse tissues. In Vivo \{(Athens\}, Greece), 8, 343-351.

Kovářù, F., Mareš, V., Kovářù, H., Kovárů, F., Mares, V., y Kovárů, H. (1984) Immunocytochemical study of alpha-fetoprotein in the central nervous system and thymus of pig embryos. The Histochemical journal, 16, 456-8.

Kriegstein, A. y Alvarez-Buylla, A. (2009) The glial nature of embryonic and adult neural stem cells. Annu Rev Neurosci, 32, 149-84. 
Kronquist, K.E., Dreazen, E., Keener, S.L., Nicholas, T.W., y Crandall, B.F. (1990) Reduced fetal hepatic alpha-fetoprotein levels in Down's syndrome. Prenatal Diagnosis, 10, 739-751.

Laderoute, M.P. y Pilarski, L.M. (1994) The inhibition of apoptosis by alpha-fetoprotein (AFP) and the role of AFP receptors in anti-cellular senescence. Anticancer research, 14, 2429-38.

Laemmli, U.K. (1970) Cleavage of structural proteins during the assembly of the head of bacteriophage T4. Nature, 227, 680-685.

Lee, J.E. (1997) Basic helix-loop-helix genes in neural development. Curr Opin Neurobiol, 7, 13-20.

Lehtinen, M.K., Zappaterra, M.W., Chen, X., Yang, Y.J., Hill, A.D., Lun, M., Maynard, T., Gonzalez, D., Kim, S., Ye, P., D’Ercole, a J., Wong, E.T., LaMantia, A.S., y Walsh, C. a (2011) The cerebrospinal fluid provides a proliferative niche for neural progenitor cells. Neuron, 69, 893-905.

Leong, S.S.J. y Middelberg, A.P.J. (2006) The refolding of different alphafetoprotein variants. Protein Sci, 15, 2040-50.

Leong, S.S.J. y Middelberg, A.P.J. (2007) A simplified bioprocess for human alpha-fetoprotein production from inclusion bodies. Biotechnol Bioeng, 97, 99-117.

Levi-Montalcini, R. (1982) Developmental neurobiology and the natural history of nerve growth factor. Ann. Rev. Neurosci., 5, 341-362.

Li, M.-S., Li, P.-F., Chen, Q., Du, G.-G., y Li, G. (2004) Alpha-fetoprotein stimulated the expression of some oncogenes in human hepatocellular carcinoma Bel 7402 cells. World Journal of Gastroenterology: WJG, 10, 819-824.

Li, M.S., Li, P.F., Yang, F.Y., He, S.P., Du, G.G., y Li, G. (2002) The intraceIlular mechanism of alpha-fetoprotein promoting the proliferation of NIH 3T3 cells. Cell Research, 12, 151-156.

Li, M.S.M., Li, P.P.F., He, S.P.S., Du, G.G.G., Li, G., y others (2002) The promoting molecular mechanism of alpha-fetoprotein on the growth of human 
hepatoma Be17402 cell line. World Journal of, 8, 469-475.

Liddelow, S. a, Dziegielewska, K.M., VandeBerg, J.L., Noor, N.M., Potter, a M., y Saunders, N.R. (2011) Modification of protein transfer across blood/cerebrospinal fluid barrier in response to altered plasma protein composition during development. The European journal of neuroscience, 33, 391-400.

Liddelow, S.A., Dziegielewska, K.M., Vandeberg, J.L., y Saunders, N.R. (2010) Development of the lateral ventricular choroid plexus in a marsupial, Monodelphis domestica. Cerebrospinal fluid research, 7, 16.

Lipton, S.A. y Kater, S.B. (1989) Neurotransmitter regulation of neuronal outgrowth, plasticity and survival. Trends Biochem. Sci., 12, 265-270.

Liu, L., Guo, J., Yuan, L., Cheng, M., Cao, L., Shi, H., Tong, H., Wang, N., y De, W. (2007) Alpha-fetoprotein is dynamically expressed in rat pancreas during development. Development, Growth \& Differentiation, 49, 669-681.

Liu, Y., Belayev, L., Zhao, W., Busto, R., Belayev, A., y Ginsberg, M.D. (2001) Neuroprotective effect of treatment with human albumin in permanent focal cerebral ischemia: histopathology and cortical perfusion studies. Eur $J$ Pharmacol, 428, 193-201.

Luckenbill, E.L. (1997) Laminin and the mechanism of neuronal outgrowth. Brain Res., 23, 1-27.

Luhmann, H.J. (2003) Cellular physiology of the neonatal rat cerebral cortex. Brain Research Bulletin, 60, 345-353.

Lund, R.D. y Mustari, M.J. (1977) Development of the geniculocortical pathway in rat. The Journal of Comparative Neurology, 173, 289-305.

López-Bendito, G. y Molnár, Z. (2003) Thalamocortical development: how are we going to get there? Nature reviews. Neuroscience, 4, 276-89.

López-Bendito, G., Cautinat, A., Sánchez, J.A., Bielle, F., Flames, N., Garratt, A.N., Talmage, D.A., Role, L.W., Charnay, P., Marín, O., y Garel, S. (2006) Tangential Neuronal Migration Controls Axon Guidance: A Role for Neuregulin-1 in Thalamocortical Axon Navigation. Cell, 125, 127-142. 
Maccioni, R.B. y Cambiazo, V. (1995) Role of microtubule-associated proteins in the control of microtubule assembly. Physiological reviews, 75, 835864.

Madtes, J.P. y Redburn, D.A. (1983) GABA as a trophic factor during development. Life Sci., 33, 979-984.

Marin, O. y Rubenstein, J.L.R. (2001) A long, remarkable journey: Tangential migration in the telencephalon. Nat Rev Neurosci, 2, 780-790.

Martínez-Cerdeño, V., Noctor, S.C., y Kriegstein, A.R. (2006) Estradiol stimulates progenitor cell division in the ventricular and subventricular zones of the embryonic neocortex. The European Journal of Neuroscience, 24, 34753488 .

Marín, O. (2002) Origin of cortical interneurons: basic concepts and clinical implications]. Revista de neurologia, 35, 743.

Marín, O. y Rubenstein, J.L.R. (2003) Cell migration in the forebrain. Annual review of neuroscience, 26, 441-83.

Mashayekhi, F., Draper, C.E., Bannister, C.M., Pourghasem, M., OwenLynch, P.J., y Miyan, J.A. (2002) Deficient cortical development in the hydrocephalic Texas (H-Tx) rat: a role for CSF. Brain : a Journal of Neurology, 125, 1859-1874.

Mauch, D.H., Nagler, K., Schumacher, S., Goritz, C., Muller, E.C., Otto, A., y Pfrieger, F.W. (2001) CNS synaptogenesis promoted by glia-derived cholesterol. Science, 294, 1354-7.

McBain, C.J. y Fisahn, A. (2001) Interneurons unbound. Nat Rev Neurosci, 2, 11-23.

McNutt, M.A., Li, G., Li, M., Li, H., Li, C., Zhou, S., Guo, L., Liu, H., Jiang, W., Liu, X., y Li, P. (2009) Alpha fetoprotein is a novel protein-binding partner for caspase-3 and blocks the apoptotic signaling pathway in human hepatoma cells. International Journal of Cancer, 124, 2845-2854.

McQuillen, P.S., DeFreitas, M.F., Zada, G., y Shatz, C.J. (2002) A Novel 
Role for p75NTR in Subplate Growth Cone Complexity and Visual Thalamocortical Innervation The Journal of Neuroscience , 22 , 3580-3593.

Medina, J.M. y Tabernero, A. (2002) Astrocyte-synthesized oleic acid behaves as a neurotrophic factor for neurons. Journal of Physiology, Paris, 96, 265-71.

Medina, J.M. y Tabernero, A. (2010) The Neurotrophic Effect of Oleic Acid: Implications for Olive Oil in Health and Disease. En Preedy, V.R. y Watson, R.R. (eds), Olives and Olive Oil in Health and Disease Prevention. Academic Press, San Diego, págs. 1405-1412.

Meisami, E. y Timiras, P.S. (1982) Normal and abnormal biochemical development of the brain after birth. En Jones, C.T. (ed), Biochemical Development of the Fetus and Neonate. Elsevier Biomedical Press, Amsterdam, págs. 759-821.

Mesfin, F.B., Bennett, D.A., Jacobson, H.I., Zhu, S., y Andersen, T.T. (2000) Alpha-fetoprotein-derived antiestrotrophic octapeptide. Biochimica et biophysica acta, 1501, 33-43.

Michler, A. (1990) Involvement of GABA receptors in the regulation of neurite growth in cultured embryonic chick tectum. Int. J. Dev. Neurosci., 8, 463472.

Mission, J.-P., Austin, C.P., Takahashi, T., Cepko, C.L., y Caviness, V.S.J. (1991) The Alignment of Migrating Neural Cells in Relation to the Murine Neopallial Radial Glial Fiber System. Cerebral Cortex, 1, 221-229.

Miyan, J.A., Zendah, M., Mashayekhi, F., y Owen-Lynch, P.J. (2006) Cerebrospinal fluid supports viability and proliferation of cortical cells in vitro, mirroring in vivo development. Cerebrospinal fluid research, 3, 2.

Miyazaki, M., Matsuura, K., Wahid, S., Izumi, M., Taketa, K., y Sato, J. (1981) A simple method for purification of rat alpha-fetoprotein by affi-gel blue chromatography and disc electrophoresis. Acta Med Okayama, 35, 427-30.

Mizejewski, G.J. (1983) Estradiol-Activated alpha -fetoprotein Suppresses the Uterotropic Response to Estrogens. Proceedings of the National Academy 
of Sciences, 80, 2733-2737.

Mizejewski, G.J. (1994) Alpha-fetoprotein binding proteins: Implications for transmembrane passage and subcellular localization. Life sciences, 56, 1-9.

Mizejewski, G.J. (1995a) The phylogeny of alpha-fetoprotein in vertebrates: survey of biochemical and physiological data. Critical Reviews in Eukaryotic Gene Expression, 5, 281-316.

Mizejewski, G.J. (1995b) Alpha-fetoprotein signal sequences: a proposed mechanism for subcellular localization and organelle targeting. Journal of theoretical biology, 176, 103-13.

Mizejewski, G.J. (2001) Alpha-fetoprotein structure and function: relevance to isoforms, epitopes, and conformational variants. Experimental biology and medicine (Maywood, N.J.), 226, 377-408.

Mizejewski, G.J. (2002) Biological role of alpha-fetoprotein in cancer: prospects for anticancer therapy. Expert Review of Anticancer Therapy, 2, 709735.

Mizejewski, G.J. (2004) Biological roles of alpha-fetoprotein during pregnancy and perinatal development. Experimental biology and medicine (Maywood, N.J.), 229, 439-63.

Mizejewski, G.J. (2007) The alpha-fetoprotein-derived growth inhibitory peptide 8-mer fragment: review of a novel anticancer agent. Cancer biotherapy \& radiopharmaceuticals, 22, 73-98.

Mizejewski, G.J. (2009) Mapping of Structure-Function Peptide Sites on the Human Alpha-fetoprotein Amino Acid Sequence. Atlas of Genetics and Cytogenetics in Oncology and Haematology, 14, 169-216.

Mizejewski, G.J. (2011) Mechanism of Cancer Growth Suppression of Alpha-Fetoprotein Derived Growth Inhibitory Peptides (GIP): Comparison of GIP-34 versus GIP-8 (AFPep). Updates and Prospects. Cancers, 3, 27092733.

Mizejewski, G.J. y Pass, K. a. (2001) Fatty Acids, Alpha-Fetoprotein, and 
Cystic Fibrosis. Pediatrics, 108, 1370-1373.

Mizejewski, G.J. y Warner, A.S. (1989) Alpha-fetoprotein can regulate growth in the uterus of the immature and adult ovariectomized mouse. Journal of reproduction and fertility, 85, 117-185.

Molnár, Z. y Blakemore, C. (1995) How do thalamic axons find their way to the cortex? Trends in Neurosciences, 18, 389-397.

Molnár, Z. y Cordery, P. (1999) Connections between cells of the internal capsule, thalamus, and cerebral cortex in embryonic rat. The Journal of comparative neurology, 413, 1-25.

Molnár, Z., Adams, R., y Blakemore, C. (1998) Mechanisms underlying the early establishment of thalamocortical connections in the rat. The Journal of neuroscience: the official journal of the Society for Neuroscience, 18, 572345.

Molyneaux, B.J., Arlotta, P., Menezes, J.R.L., y Macklis, J.D. (2007) Neuronal subtype specification in the cerebral cortex. Nature Reviews. Neuroscience, 8, 427-437.

Montiel, J.F., Wang, W.Z., Oeschger, F.M., Hoerder-Suabedissen, A., Tung, W.L., García-Moreno, F., Holm, I.E., Villalón, A., y Molnár, Z. (2011) Hypothesis on the dual origin of the Mammalian subplate. Frontiers in neuroanatomy, 5, 25.

Monuki, E.S. y Walsh, C.A. (2001) Mechanisms of cerebral cortical patterning in mice and humans. Nature Neuroscience, 4 Suppl, 1199-1206.

Moro-Vidal, R. (s/f) The alpha-fetoprotein receptor: A widespread cancer marker of clinical potential. oncopetdiagnostics.com, 1-18.

Moskaleva EYu, Posypanova, G.A., Shmyrev, I.I., Rodina, A.V., Muizhnek, E.L., Severin, E.S., Katukov VYu, Luzhkov, Y.M., y Severin, S.E. (1997) Alphafetoprotein-mediated targeting--a new strategy to overcome multidrug resistance of tumour cells in vitro. Cell biology international, 21, 793-9.

Mosmann, T. (1983) Rapid colorimetric assay for cellular growth and survi- 
val: application to proliferation and cytotoxicity assays. J Immunol Methods, 65, 55-63.

Muglia, L. y Locker, J. (1984) Developmental regulation of albumin and $\alpha-$ fetoprotein gene expression in the rat. Nucleic Acids Research, 12, 67516762.

Møllgård, K. y Jacobsen, M. (1984) Immunohistochemical identification of some plasma proteins in human embryonic and fetal forebrain with particular reference to the development of the neocortex. Brain Research, 315, 49-63.

Møllgård, K., Dziegielewska, K.M., Saunders, N.R., Zakut, H., y Soreq, H. (1988) Synthesis and localization of plasma proteins in the developing human brain. Integrity of the fetal blood-brain barrier to endogenous proteins of hepatic origin. Developmental biology, 128, 207.

Møllgård, K., Jacobsen, M., y Jacobsen, G. (1979) Immunohistochemical evidence for an intracellular localization of plasma proteins in human foetal choroid plexus and brain. Neuroscience, 14, 85-90.

Nadal, A., Fuentes, E., Pastor, J., y McNaughton, P.A. (1995) Plasma albumin is a potent trigger of calcium signals and DNA synthesis in astrocytes. Proc. Natl. Acad. Sci. USA, 92, 1426-1430.

Nadarajah, B. y Parnavelas, J.G. (2002) Modes of neuronal migration in the developing cerebral cortex. Nat Rev Neurosci, 3, 423-432.

Nadarajah, B., Brunstrom, J.E., Grutzendler, J., Wong, R.O., y Pearlman, a L. (2001) Two modes of radial migration in early development of the cerebral cortex. Nature neuroscience, 4, 143-50.

Nahon, J.L. (1987) The regulation of albumin and alpha-fetoprotein gene expression in mammals. Biochimie, 69, 445-459.

Nelson, T.L. (1961) Serum protein and lipoprotein fractions in mongolism. Am. J. Dis. Chil., 102, 369-374.

Newby, D., Dalgliesh, G., Lyall, F., y Aitken, D.A. (2005) Alphafetoprotein and alphafetoprotein receptor expression in the normal human placenta at 


\section{Alejandro García García}

term. Placenta, 26, 190-200.

Newman, E.S. (1978) Isolation of alpha-1-fetoprotein.

Newman, E.S. (1979) Process for the preparation of purified alpha-1-fetoprotein and its application.

Nishi, S., Matsue, H., Yoshida, H., Yamaoto, R., y Sakai, M. (1991) Localization of the estrogen-binding site of alpha-fetoprotein in the chimeric humanrat proteins. Proceedings of the National Academy of Sciences of the United States of America, 88, 3102-5.

Nishio, H. y Dugaiczyk, a (1996) Complete structure of the human alphaalbumin gene, a new member of the serum albumin multigene family. Proceedings of the National Academy of Sciences of the United States of America, 93, 7557-61.

Oestreicher, A.B., De Graan, P.N.E., Gispen, W.H., Verhaagen, J., y Schrama, L.H. (1997) B-50, the growth associated protein-43: modulation of cell morphology and communication in the nervous system. Progress in neurobio$\log y$, 53, 627-686.

Ohtsuka, T., Asahi, M., Matsuura, N., Kikuchi, H., Hojo, M., Kageyama, R., Ohkubo, H., y Hoshimaru, M. (1998) Regulated expression of neurogenic basic helix-loop-helix transcription factors during differentiation of the immortalized neuronal progenitor cell line HC2S2 into neurons. Cell Tissue Res, 293, 23-9.

Olmsted, J.B. (1986) Microtubule-associated proteins. Annu Rev Cell Biol, 2, 421-57.

Oppenheim, R.W. (1991) Cell death during development of the nervous system. Annu Rev Neurosci, 14, 453-501.

Owen-Lynch, P.J., Draper, C.E., Mashayekhi, F., Bannister, C.M., y Miyan, J.A. (2003) Defective cell cycle control underlies abnormal cortical development in the hydrocephalic Texas rat. Brain: A Journal of Neurology, 126, 623631. 
O'Leary, D.D. y Koester, S.E. (1993) Development of projection neuron types, axon pathways, and patterned connections of the mammalian cortex. Neuron, 10, 991-1006.

Papaconstantinou, J., Rabek, J.P., y Zhang, D.-er (1990) Molecular Mechnisms of Liver-Specific Albumin and a-Fetoprotein Gene Regulation: A Review. Regulation, 32, 205-216.

Paquette, A., Wang, D., Jankowski, M., Gutkowska, J., y Lavoie, J.-M. (2008) Effects of ovariectomy on PPAR alpha, SREBP-1c, and SCD-1 gene expression in the rat liver. Menopause (New York, N.Y.), 15, 1169-1175.

Parikh, R.R.R., Gildener-Leapman, N., Narendran, A., Lin, H.-Y.H.Y., Lemanski, N., Bennett, J.A., Jacobson, H.I.H.I., y Andersen, T.T.T.T. (2005) Prevention of $\mathrm{N}$-methyl-N-nitrosourea-induced breast cancer by alpha-fetoprotein (AFP)-derived peptide, a peptide derived from the active site of AFP. Clinical cancer research: an official journal of the American Association for Cancer Research, 11, 8512-20.

Park, D., Choi, D., Lee, J., Lim, D.-sik, y Park, C. (2010) Male-like sexual behavior of female mouse lacking fucose mutarotase. BMC genetics, 11, 62.

Parmelee, D.C., Evenson, M.A., y Deutsch, H.F. (1978) The presence of fatty acids in human alpha-fetoprotein. Journal of Biological Chemistry, 253, 2114.

Paton, C.M. y Ntambi, J.M. (2009) Biochemical and physiological function of stearoyl-CoA desaturase. American journal of physiology. Endocrinology and metabolism, 297, E28-37.

Perrone-Bizzozero, N.I., Cansino, V.V., y Kohn, D.T. (1993) Post-transcriptional regulation of GAP-43 gene expression in PC12 cells through protein kinase C-dependent stabilization of the messenger RNA. J. Cell Biol., 120, 1263-1270.

Piñeiro, A., Calvo, M., Iguaz, F., Lampreave, F., Naval, J., Pñeiro, A., y Pneiro, A. (1982) Characterization, origin and evolution of alpha-fetoprotein and albumin in postnatal rat brain. International Journal of Biochemistry, 14, 
817-823.

Plateel, M., Teissier, E., y Cecchelli, R. (1997) Hypoxia dramatically increases the nonspecific transport of blood-borne proteins to the brain. Journal of neurochemistry, 68, 874-7.

Pleasure, S.J., Anderson, S., Hevner, R., Bagri, A., Marin, O., Lowenstein, D.H., y Rubenstein, J.L.R. (2000) Cell Migration from the Ganglionic Eminences Is Required for the Development of Hippocampal GABAergic Interneurons. Neuron,.

Poirier, J. (1994) Apolipoprotein E in animal models of CNS injury and in Alzheimer's disease. Trends Neurosci, 17, 525-30.

Polo-Hernández, E. (2009) Las neuronas del estriado son las diana del efecto neurotrófoc del ácido oleico sintetizado en la zona subventricular durante el desarrollo postnatal (tesis doctoral). Universidad de Salamanca, Salamanca.

Polo-Hernández, E., de Castro, F., García-García, A.G., Tabernero, A., Medina, J.M., y Polo-Hernandez, E. (2010) Oleic acid synthesized in the periventricular zone promotes axonogenesis in the striatum during brain development. Journal of Neurochemistry, 114, 1756-66.

Price, D.J., Kennedy, H., Dehay, C., Zhou, L., Mercier, M., Jossin, Y., Goffinet, A.M., Tissir, F., Blakey, D., y Molnár, Z. (2006) The development of cortical connections. The European journal of neuroscience, 23, 910-20.

Puelles, L. (2009) Forebrain Development: Prosomere Model. En Larry, R.S. (ed), Encyclopedia of Neuroscience. Academic Press, Oxford, págs. 315319.

Puelles, L. y Rubenstein, J.L.R. (2003) Forebrain gene expression domains and the evolving prosomeric model. Trends in Neurosciences, 26, 469476.

Puttmann, M., Krug, H., von Ochsenstein, E., y Kattermann, R. (1993) Fast HPLC determination of serum free fatty acids in the picomole range. Clin Chem, 39, 825-32. 
Rachidi, M. y Lopes, C. (2007) Mental retardation in Down syndrome: from gene dosage imbalance to molecular and cellular mechanisms. Neuroscience research, 59, 349-69.

Rakic, P. (1974) Neurons in Rhesus Monkey Visual Cortex: Systematic Relation between Time of Origin and Eventual Disposition Science, 183, 425-427.

Rakic, P. (1978) Neuronal migration an contact guidance in primate telencephalon. Postgrad. Med. J., 54, 25-40.

Rakic, P. (1985) Limits of neurogenesis in primates. Science, 227, 10541056.

Raper, J. y Tessier-Lavigne, M. (1999) Growth cones and axon pathfinding. En Zimond, M., Bloom, F., Landis, S., Roberts, J., y Squire, L. (eds), Fundamental Neuroscience. Academic Press, San Diego, págs. 519-546.

Reisert, I., Han, V., Hartwig, S., Ahnert-Hilger, G., y Pilgrim, C. (1989) Rapid maturation of synaptic functions of prenatal serotoninergic neurons in short-term cultures: absence of sex differences and hormone effects. Neurosci., 32, 133-139.

Reynolds, M.L.M. y Møllgård, K. (1985) The distribution of plasma proteins in the neocortex and early allocortex of the developing sheep brain. Anatomy and embryology, 171, 41.

Robertson, R.T., Annis, C.M., Baratta, J., Haraldson, S., Ingeman, J., Kageyama, G.H., Kimm, E., y Yu, J. (2000) Do subplate neurons comprise a transient population of cells in developing neocortex of rats? The Journal of comparative neurology, 426, 632-50.

Rodríguez-Rodríguez, R.A., Tabernero, A., Velasco, A., Lavado, E.M., y Medina, J.M. (2004) The neurotrophic effect of oleic acid includes dendritic differentiation and the expression of the neuronal basic helix-loop-helix transcription factor NeuroD2. J Neurochem, 88, 1041-51.

de la Rosa, E.J. y de Pablo, F. (2000) Cell death in early neural development: beyond the neurotrophic theory. Trends in neurosciences, 23, 454-8. 
Rubenstein, J.L.R., Martinez, S., Shimamura, K., y Puelles, L. (1994) The embryonic vertebrate forebrain: the prosomeric model. Science, 266, 578578.

Sanes, J. y Jessell, T.M. (2001) Guía de los axones hacia sus objetivos. En Kandel, E. y Schwartz, J. (eds), Principios De Neurociencia. McGraw-Hill/ Interamericana de España, Madrid, págs. 1063-1086.

Sarnat, H.B. y Flores-Sarnat, L. (2002) Cajal-Retzius and subplate neurons: their role in cortical development. European journal of paediatric neurology: EJPN : official journal of the European Paediatric Neurology Society, $\mathbf{6}$, 91-7.

Saunders, N.R., Ek, C.J., Habgood, M.D., Johansson, P.A., Liddelow, S.A., y Dziegielewska, K.M. (2011) Assessing Blood-Cerebrospinal Fluid Barrier Permeability in the Rat Embryo. Methods in Molecular Biology (Clifton, N.J.), 686, 247-265.

Saunders, N.R., Ek, C.J., Habgood, M.D., y Dziegielewska, K.M. (2008) Barriers in the brain: a renaissance? Trends in neurosciences, 31, 279-86.

Saunders, N.R., Knott, G.W., y Dziegielewska, K.M. (2000) Barriers in the immature brain. Cellular and molecular neurobiology, 20, 29-40.

Savu, L., Benassayag, C., Vallette, G., Nunez, E.A., y Jayle, M.F. (1977) Purification and estrogen binding properties of mouse alpha1-fetoprotein and of two forms of the protein with different affinities for concanavalin-A. Biochimie, 59, 323-328.

Schachter, B.S., Toran-Allerand, C.D., y Dominique Toran-Allerand, C. (1982) Intraneuronal alpha-fetoprotein and albumin are not synthesized locally in developing brain. Brain research, 5, 93-8.

Schoenfeld, T.A. y Obar, R.A. (1994) Diverse distribution and function of fibrous microtubule-associated proteins in the nervous system. Int Rev Cytol, 151, 67-137.

Seaton, P., Hunt, A., y Patel, A.J. (1988) Production by astrocytes of a trophic factor for cholinergic neurons. Biochem. Soc. Trans., 16, 296-297. 
Sell, S., Longley, M.A., y Boulter, J. (1985) a-Fetoprotein and Albumin gene expression in brain and other tissues of fetal and adult rats. Developmental Brain Research, 22, 49-53.

Semenkova, L., Dudich, E., Dudich, I., Tokhtamisheva, N., Tatulov, E., Okruzhnov, Y., Garcia-Foncillas, J., Palop-Cubillo, J.-A., y Korpela, T. (2003) Alpha-fetoprotein positively regulates cytochrome c-mediated caspase activation and apoptosome complex formation. European Journal of Biochemistry, 270, 4388-4399.

Shah, S.N. (1979) Fatty acid composition of lipids of human brain myelin and synaptosomes: changes in phenylketonuria and Down's syndrome. Int $J$ Biochem, 10, 477-82.

Sheetz, M.P., Pfister, K.K., Bulinski, J.C., y Cotman, C.W. (1998) Mechanisms of trafficking in axons and dendrites: implications for development and neurodegeneration. Prog Neurobiol, 55, 577-94.

Skene, J.H.P. (1989) Axonal growth-associated proteins. Ann. Rev. Neurosci., 12, 127-156.

Skene, J.H.P. y Virág, I. (1989) Posttranslational membrane attachment and dynamic fatty acylation of a neuronal growth cone protein, GAP-43. J. Cell Biol., 108, 613-624.

Soriano, E. y Del Río, J.A. (2005) The cells of cajal-retzius: still a mystery one century after. Neuron, 46, 389-94.

Spector, A.A. y Fletcher, J.E. (1978) Transport of fatty acid in the circulation. En JM, D., AM, G., y JA, O. (eds), Disturbances in Lipid and Lipoprotein Metabolism. American Physiological Society, Bethesda, Maryland, págs. 229249.

Spoelgen, R., Hammes, A., Anzenberger, U., Zechner, D., Andersen, O.M., Jerchow, B., y Willnow, T.E. (2005) LRP2/megalin is required for patterning of the ventral telencephalon. Development, 132, 405-14.

Spoerri, P.E. (1988) Neurotrophic effects of GABA in cultures of embryonic chick brain and retina. Synapse, 2, 11-22. 
Stray-Pedersen, a, Borresen-Dale, a L., Paus, E., Lindman, C.R., Burgers, T., y Abrahamsen, T.G. (2007) Alpha fetoprotein is increasing with age in ataxia-telangiectasia. European journal of paediatric neurology: EJPN : official journal of the European Paediatric Neurology Society, 11, 375-80.

Susan K., M. (1988) Development and decision-making in the mammalian cerebral cortex. Brain Research Reviews, 13, 1-23.

Sánchez, C., Díaz-Nido, J., y Avila, J. (2000) Phosphorylation of microtubule-associated protein 2 (MAP2) and its relevance for the regulation of the neuronal cytoskeleton function. Prog Neurobiol, 61, 133-68.

Tabernero, A., Bolaños, J.P., y Medina, J.M. (1993) Lipogenesis from lactate in rat neurons and astrocytes in primary culture. The Biochemical Journal, 294 ( Pt 3, 635-638.

Tabernero, A., Granda, B., Medina, A., Sánchez-Abarca, L.I., Lavado, E., y Medina, J.M. (2002) Albumin promotes neuronal survival by increasing the synthesis and release of glutamate. Journal of Neurochemistry, 81, 881-891.

Tabernero, A., Jimenez, C., Velasco, A., Giaume, C., y Medina, J.M. (2001) The enhancement of glucose uptake caused by the collapse of gap junction communication is due to an increase in astrocyte proliferation. $J$. Neurochem., 78, 890-8.

Tabernero, A., Lavado, E.M., Granda, B., Velasco, A., y Medina, J.M. (2001) Neuronal differentiation is triggered by oleic acid synthesized and released by astrocytes. Journal of Neurochemistry, 79, 606-16.

Tabernero, A., Medina, A., Sánchez-Abarca, L.I., Lavado, E., y Medina, J.M. (1999) The effect of albumin on astrocyte energy metabolism is not brought about through the control of intercellular $\mathrm{Ca} 2+$ concentrations but by free-fatty acid sequestration. Glia, 25, 1-9.

Tabernero, A., Orfao, A., y Medina, J.M. (1996) Astrocyte differentiation in primary culture followed by flow cytometry. Neurosci. Res., 24, 131-138.

Tabernero, A., Velasco, A., Granda, B., Lavado, E.M., y Medina, J.M. (2002) Transcytosis of albumin in astrocytes activates the sterol regulatory 
element-binding protein-1, which promotes the synthesis of the neurotrophic factor oleic acid. J Biol Chem, 277, 4240-6.

Tanzi, R.E. y Bertram, L. (2005) Twenty years of the Alzheimer's disease amyloid hypothesis: a genetic perspective. Cell, 120, 545-55.

Tecce, M.F. y Terrana, B. (1990) Process for preparing human alpha-foetoprotein. European Patent, № 03514.

Terentiev, A.A. y Moldogazieva, N.T. (2006) Structural and Functional Mapping of alpha-fetoprotein. Biochemistry Moscow, 71, 120-132.

Tildon, J.T. (1993) Differential effects of serum proteins on substrate oxidation by isolated synaptosomes and cultured brain astrocytes. Dev. Neurosci., $15,226-232$.

Toran-Allerand, C.D. (1980) Coexistence of alpha-fetoprotein, albumin and transferrin immunoreactivity in neurones of the developing mouse brain. Nature, 286, 733-735.

Toran-Allerand, C.D. (1982) Regional differences in intraneuronal localization of alpha-fetoprotein in developing mouse brain. Brain research, 5, 213217.

Toran-Allerand, C.D. (1987) Neuronal uptake of alpha-fetoprotein (AFP) synthesized and secreted by hepatocytes in liver/brain co-cultures. Neuroscience letters, 83, 35-40.

Torres, C.G., Pino, A.M., y Sierralta, W.D. (2009) A cyclized peptide derived from alpha fetoprotein inhibits the proliferation of ER-positive canine mammary cancer cells. Oncology Reports, 21, 1397-1404.

Torres, J.M., Anel, A., y Uriel, J. (1992) Alpha-Fetoprotein-Mediated Uptake of Fatty Acids by Human Lymphocytes-T. J Cell Physiol Journal of Cellular Physiology, 150, 456-462.

Travis, J. y Pannell, R. (1973) Selective removal of albumin from plasma by affinity chromatography. Clinica Chimica Acta; International Journal of Clinical Chemistry, 49, 49-52. 
Trojan, J. y Uriel, J. (1979) [Intracellular localization of alpha-fetoprotein and serum albumin in the central nervous system of the rat during fetal and postnatal development]. C R Seances Acad Sci D, 289, 1157-1160.

Trojan, J. y Uriel, J. (1980) Immunocytochemical localization of alpha-fetoprotein in the developing rat brain. The Journal of the International Society for Oncodevelopmental Biology and Medicine, 1, 107-11.

Tsuboi, S., Taketa, K., Nouso, K., Fujikawa, T., Manabe, K., Ohmori, H., Higashi, T., y Shiratori, Y. (2006) High level of expression of alpha-fetoprotein receptor in gastric cancers. Tumour biology: the journal of the International Society for Oncodevelopmental Biology and Medicine, 27, 283-8.

Tsunoda, S., Sierralta, J., y Zuker, C.S. (1998) Specificity in signaling pathways: assembly into multimolecular signaling complexes. Curr Opin Genet Dev, 8, 419-22.

Twomey, S.L. y Sweet, R.V. (1976) Purification of alpha1-fetoprotein. Clin Chem, 22, 1306-9.

Um, S.H., Mulhall, C., Alisa, A., Ives, A.R., Karani, J., Williams, R., Bertoletti, A., y Behboudi, S. (2004) Alpha-fetoprotein impairs APC function and induces their apoptosis. Journal of Immunology (Baltimore, Md.: 1950), 173, $1772-1778$.

Uriel, J., Faivre-Bauman, A., Trojan, J., y Foiret, D. (1981) Immunocytochemical demonstration of alpha-fetoprotein uptake by primary cultures of fetal hemisphere cells from mouse brain. Neuroscience letters, 27, 171-5.

Uriel, J., Naval, J., y Laborda, J. (1987) a-Fetoprotein-mediated transfer of arachidonic acid into cultured cloned cells derived from a rat rhabdomyosarcoma. J. Biol. Chem., 262, 3579-3585.

Uriel, J., Trojan, J., Moro, R., Pineiro, A., Elliot, A., Hidemapsu, H., y Piñeiro, A. (1983) Intracellular uptake of alpha-fetoprotein: a marker of neural differentiation. Annals of the New York Academy of Sciences, 417, 321-9.

Uversky, V.N., Narizhneva, N.V., Ivanova, T.V., y Tomashevski, a Y. (1997) Rigidity of human alpha-fetoprotein tertiary structure is under ligand control. 
Biochemistry, 36, 13638-45.

Vallette, G., Benassayag, C., Belanger, L., y Nunez, E.A. (1977) Rat isoalpha1-fetoproteins purification and interaction with estradiol-17 $\beta$. Steroids,.

Vallette, G., Vranckx, R., Martin, M.E., Benassayag, C., y Nunez, E.A. (1989) Conformational changes in rodent and human alpha-fetoprotein: influence of fatty acids. Biochimica et biophysica acta, 997, 302-12.

Valverde, F., Santacana, M., y De Carlos, J.A. (1995) Persistence of EarlvGenerated Neurons in the Rodent Subplate: Assessment of Cell Death in Neocortex during the Early Postnatal Period. Evaluation, 15, 5014-5024.

Varon, S., Skaper, S.D., Facci, L., Rudge, J.S., y Manthorpe, M. (1987) Throphic and metabolic couplings between astroglia and neurons. En Althans, H.H. y Seifert, W. (eds), Glial-Neuronal Communication in Development and Regeneration. Springer-Verlag, Berlin, Heidelberg, págs. 493-504.

Vega, L., Arroyo, A.A., Tabernero, A., y Medina, J.M. (2009) Albumin-blunted deleterious effect of amyloid-beta by preventing the internalization of the peptide into neurons. Journal of Alzheimer's disease : JAD, 17, 795-805.

Velasco, A., Tabernero, A., y Medina, J.M. (2003) Role of oleic acid as a neurotrophic factor is supported in vivo by the expression of GAP-43 subsequent to the activation of SREBP-1 and the up-regulation of stearoyl-CoA desaturase during postnatal development of the brain. Brain Research, 977, 103-111.

Vernadakis, A. (1988) Neuron-glia interrelations. Int. Rev. Neurobiol., 30, 149-224.

Vicario, C. y Medina, J.M. (1992) Metabolism of lactate in the rat brain during the early neonatal period. J. Neurochem., 58, 32-40.

Vicario, C., Tabernero, A., y Medina, J.M. (1993) Regulation of lactate metabolism by albumin in rat neurons and astrocytes from primary culture. $\mathrm{Pe}$ diatr. Res., 34, 709-715.

Virchow, R. (1858) Die Cellularpathologie in Ihrer Begründung Auf Physio- 


\section{Alejandro García García}

logische Und Pathologische Gewebelehre: Zwanzig Vorlesungen, Gehalten Während Der Monate Februar, März Und April 1858 Im Pathologischen Institute Zu Berlin. Berlin.

Voigtlander, T. y Vogel, F. (1985) Low alpha-fetoprotein and serum albumin levels in Morbus Down may point to a common regulatory mechanism. Human genetics, 71, 276-277.

Wald, N.J. (2010) Prenatal screening for open neural tube defects and Down syndrome: three decades of progress. Prenatal Diagnosis, 30, 619-621.

Wang, W.Z., Hoerder-Suabedissen, A., Oeschger, F.M., Bayatti, N., Ip, B.K., Lindsay, S., Supramaniam, V., Srinivasan, L., Rutherford, M., Møllgård, K., Clowry, G.J., y Molnár, Z. (2010) Subplate in the developing cortex of mouse and human. Journal of anatomy, 217, 368-80.

Wang, X.-W. y Xie, H. (1998) Alpha-fetoprotein enhances the proliferation of human hepatoma cells in vitro. Life Sciences, 64, 17-23.

Wichterle, H., Turnbull, D.H., Nery, S., Fishell, G., y Alvarez-Buylla, A. (2001) In utero fate mapping reveals distinct migratory pathways and fates of neurons born in the mammalian basal forebrain Development , 128 , 37593771.

Wigle, J.T. y Eisenstat, D.D. (2008) Homeobox genes in vertebrate forebrain development and disease. Clinical Genetics, 73, 212-226.

Willnow, T.E., Hilpert, J., Armstrong, S.A., Rohlmann, A., Hammer, R.E., Burns, D.K., y Herz, J. (1996) Defective forebrain development in mice lacking gp330/megalin. Proc Natl Acad Sci U S A, 93, 8460-4.

Woolf, N.J. (1998) A structural basis for memory storage in mammals. Prog Neurobiol, 55, 59-77.

Yang, X., Zhang, Y., Zhang, L., Zhang, L., y Mao, J. (2008) Silencing alpha-fetoprotein expression induces growth arrest and apoptosis in human hepatocellular cancer cell. Cancer Letters, 271, 281-293.

Yazama, F. y Tai, A. (2011) Unexpected Role of a-Fetoprotein in Spermato- 
genesis. PloS One, 6, e19387.

Yeo, W. y Gautier, J. (2004) Early neural cell death: dying to become neurons. Developmental biology, 274, 233-44.

Yokoo, H., Kondo, T., Fujii, K., Yamada, T., Todo, S., y Hirohashi, S. (2004) Proteomic signature corresponding to alpha fetoprotein expression in liver cancer cells. Hepatology (Baltimore, Md.), 40, 609-17.

Zeidman, R., Lofgren, B., Pahlman, S., y Larsson, C. (1999) PKCepsilon, via its regulatory domain and independently of its catalytic domain, induces neurite-like processes in neuroblastoma cells. J Cell Biol, 145, 713-26.

Zlokovic, B.V., Martel, C.L., Matsubara, E., McComb, J.G., Zheng, G., McCluskey, R.T., Frangione, B., y Ghiso, J. (1996) Glycoprotein 330/megalin: probable role in receptor-mediated transport of apolipoprotein $\mathrm{J}$ alone and in a complex with Alzheimer disease amyloid beta at the blood-brain and blood-cerebrospinal fluid barriers. Proc Natl Acad Sci U S A, 93, 4229-34. 
Alejandro García García

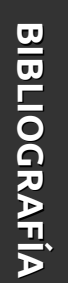


8 ANEXO 
茯 
AFP

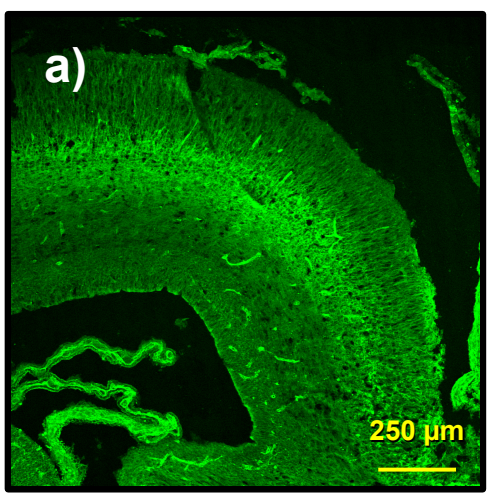

AFP
GAP-43

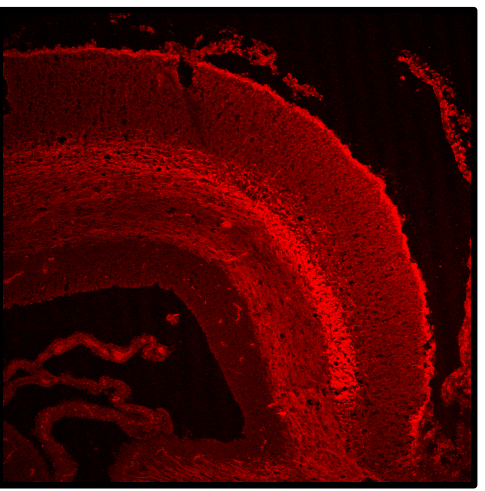

GAP-43
TO-PRO 3
Fusión

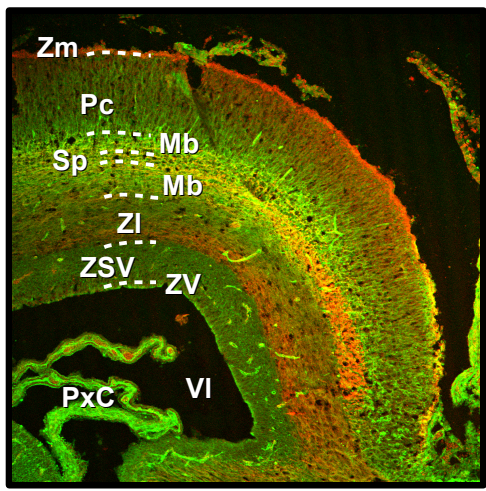

Fusión
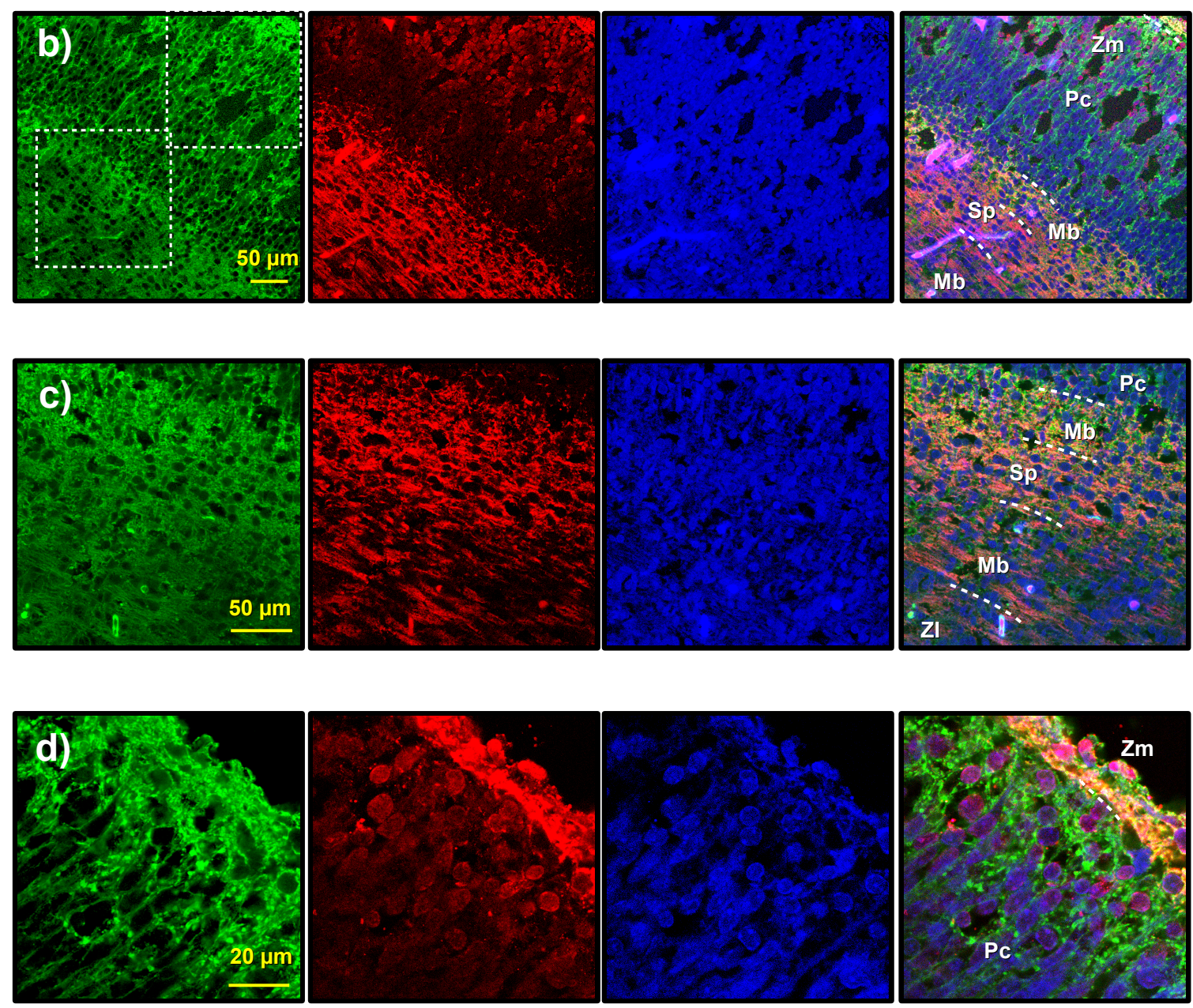

Figura A1.- Doble inmunohistoquímica confocal contra AFP y GAP-43 en el día E19,5 de desarrollo em brionario. Los fetos de 19,5 días de gestación fueron fijados mediante perfusión intracardíaca y los cerebros se cortaron en criostato en secciones de $10 \mu \mathrm{m}$. Las secciones se incubaron en primer lugar con el anticuerpo policlonal contra AFP y el anticuerpo secundario con la IgG de conejo, conjugada con Alexa-Fluor 488 y posteriormente con el anticuerpo monoclonal contra GAP-43 y el anticuerpo secundario contra lgG de ratón conjugado con Alexa-Fluor 594. Por último los núcleos se tiñeron con TO-PRO 3. Abreviaturas: Zm, zona marginal; Pc, placa cortical; Mb, materia blanca, Sp, subplaca; ZI, zona intermedia; ZSV, zona subventricular; $\mathrm{ZV}$, zona ventricular; Pxc, plexo coroideo; VI, ventrículo lateral. 

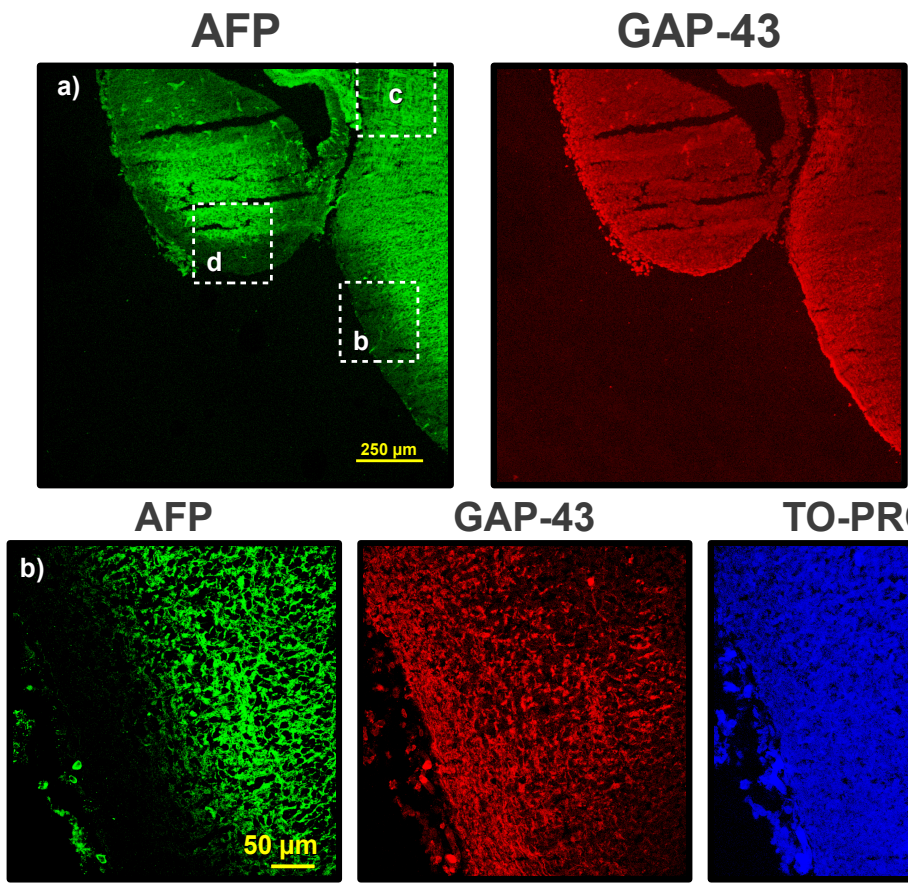

GAP-43
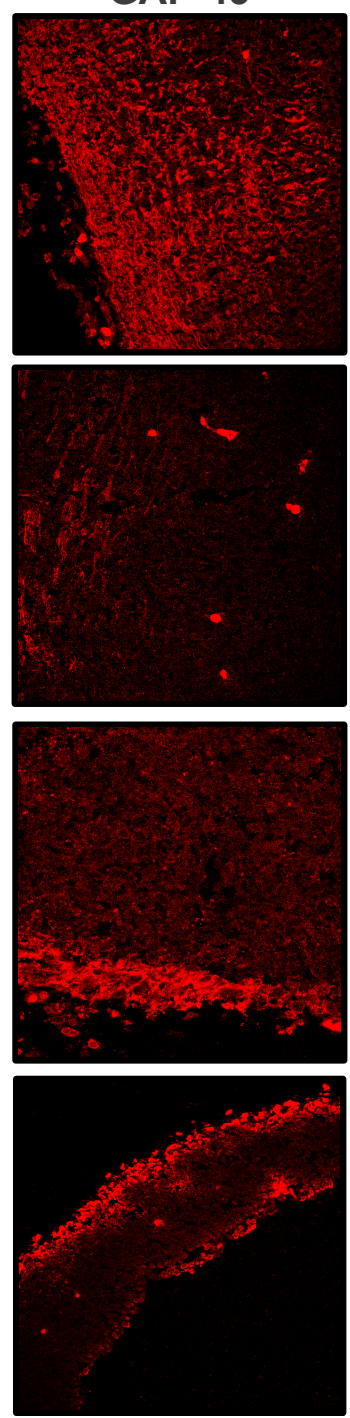

TO-PRO 3
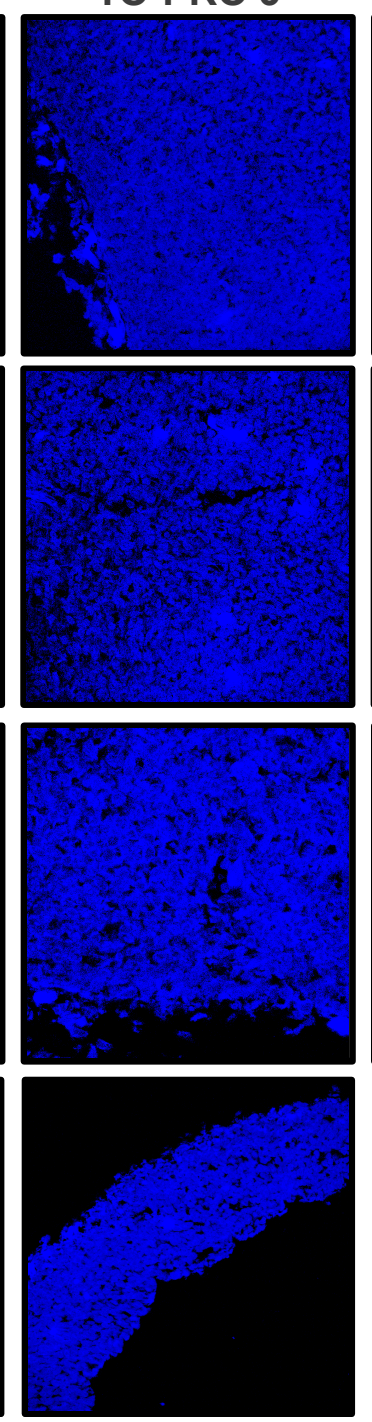

\section{Fusión}

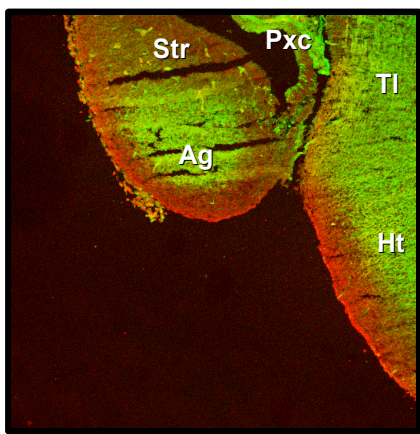

Fusión
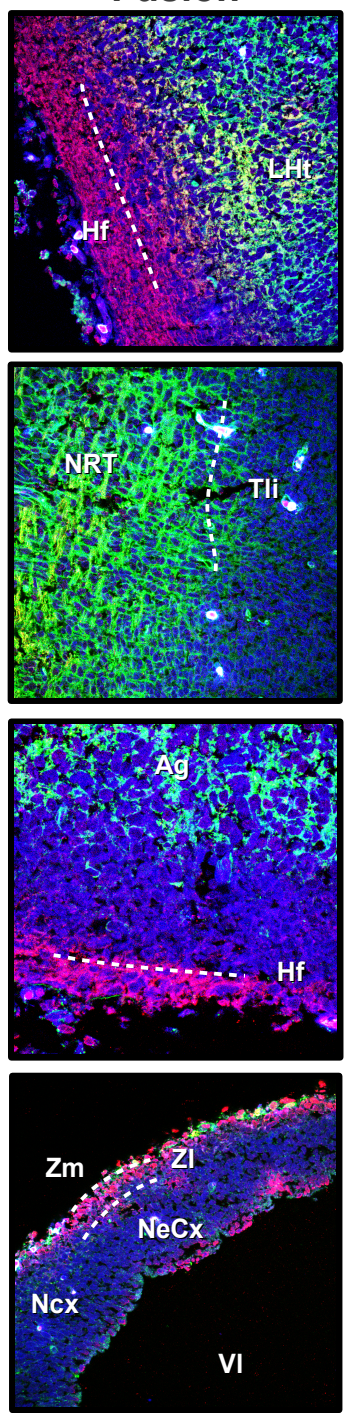

Figura A2.- Doble inmunohistoquímica confocal contra AFP y GAP-43 en el día E15,5 de desarrollo embrionario. Los embriones de 15,5 días de gestación fueron fijados mediante perfusión intracardíaca y los cerebros se cortaron en criostato en secciones de $10 \mu \mathrm{m}$. Las secciones se incubaron en primer lugar con el anticuerpo policlonal contra AFP y el anticuerpo secundario contra la IgG de conejo conjugada con Alexa Fluor 488 y posteriormente con el anticuerpo monoclonal contra GAP-43 y el anticuerpo secundario contra IgG de ratón conjugado con Alexa Fluor 594. Por último los núcleos se tiñeron con TO-PRO 3. Abreviaturas: $\mathrm{Ht}$, hipotálamo; Lht, área hipotalámica lateral; Hf, haces de fibras; Tli, tálamo intermedio; NRT núcleo reticular talámico ; Zm, zona marginal; ZI, zona intermedia; Ncx, neocortex; NeCx, neuroepitelio neocortical; VI, ventrículo lateral. 